
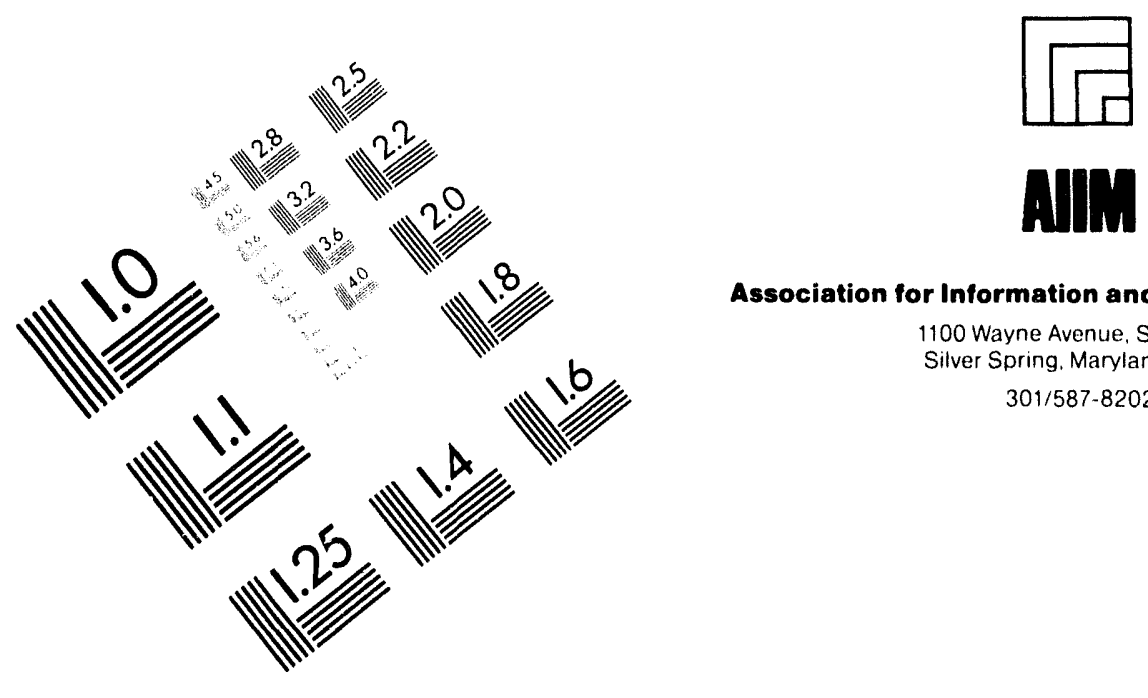

Association for Information and Image Management

1100 Wayne Avenue, Suite 1100

Silver Spring. Maryland 20910

301/587-8202

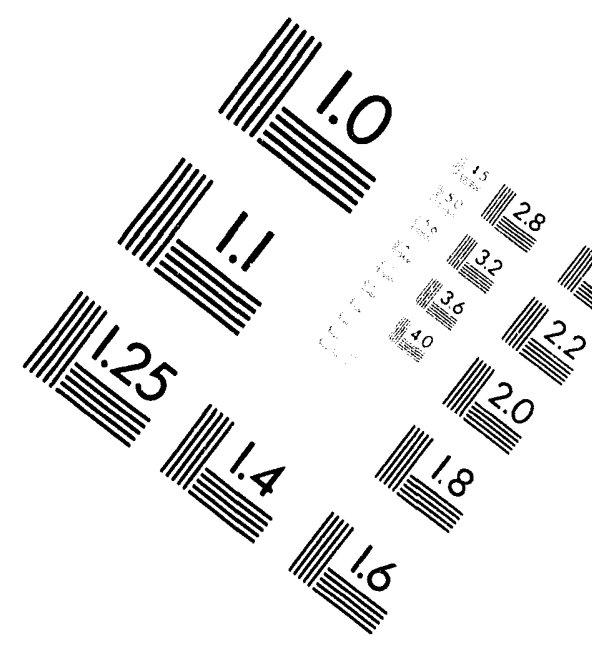

\title{
Centimeter
}

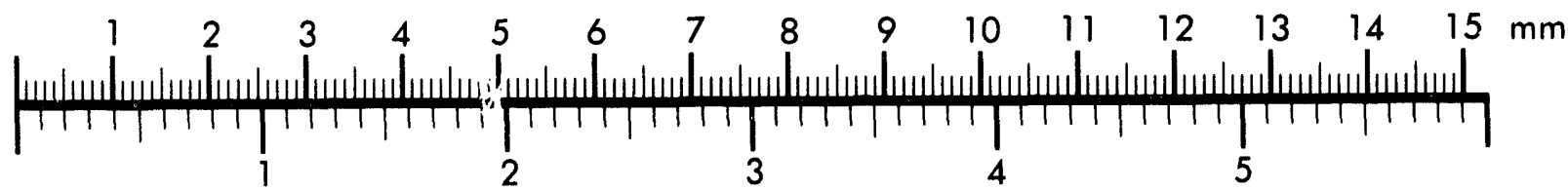

Inches
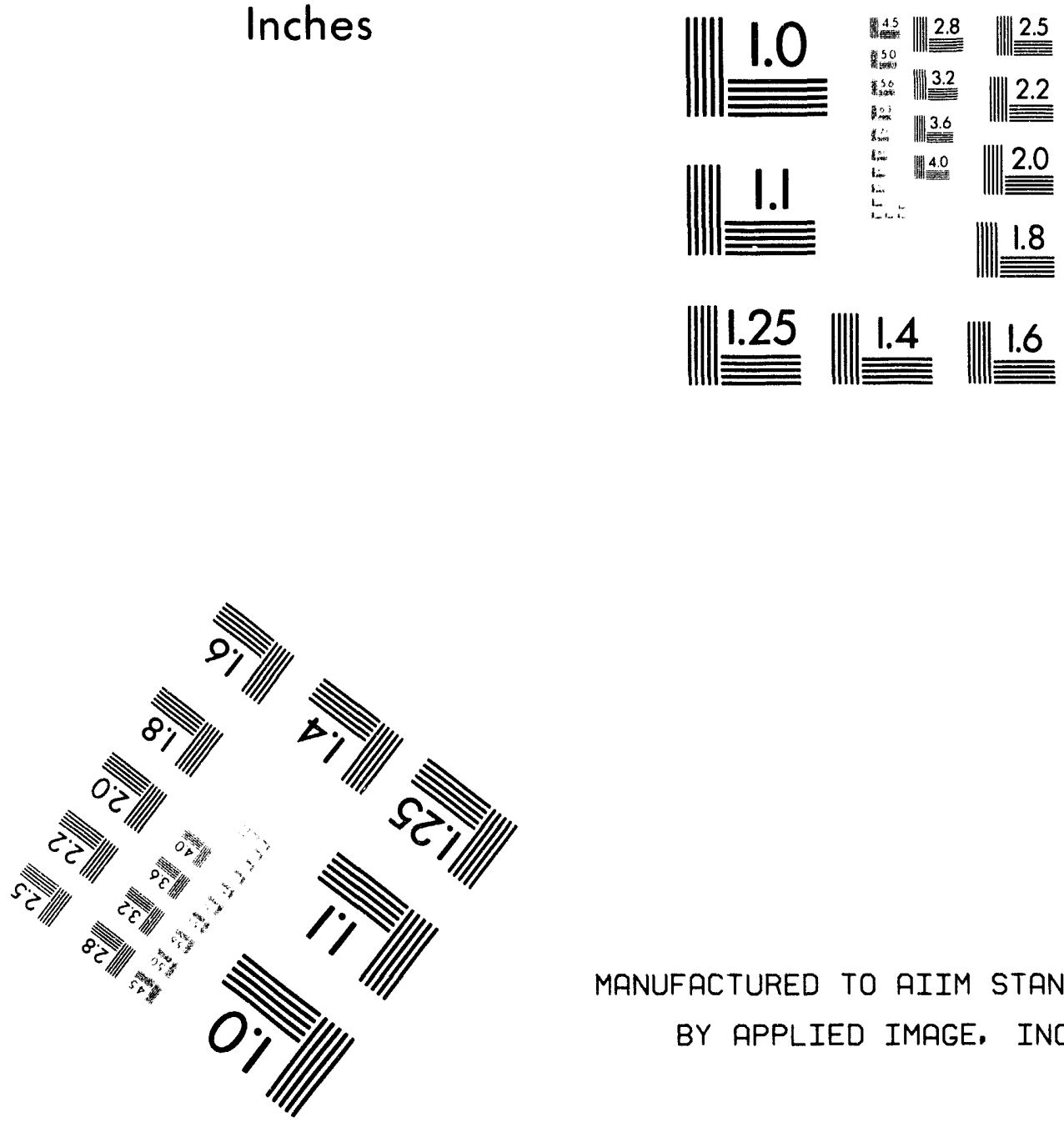

MANUFACTURED TO AIIM STANDARDS

BY APPLIED IMAGE, INC.

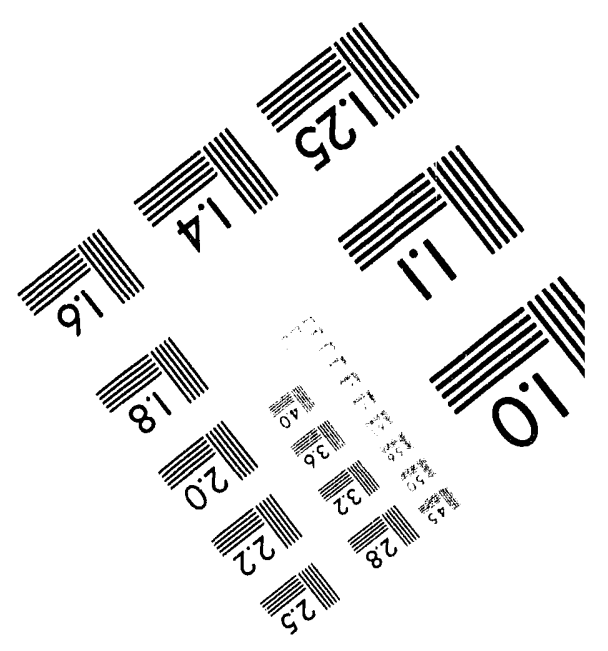



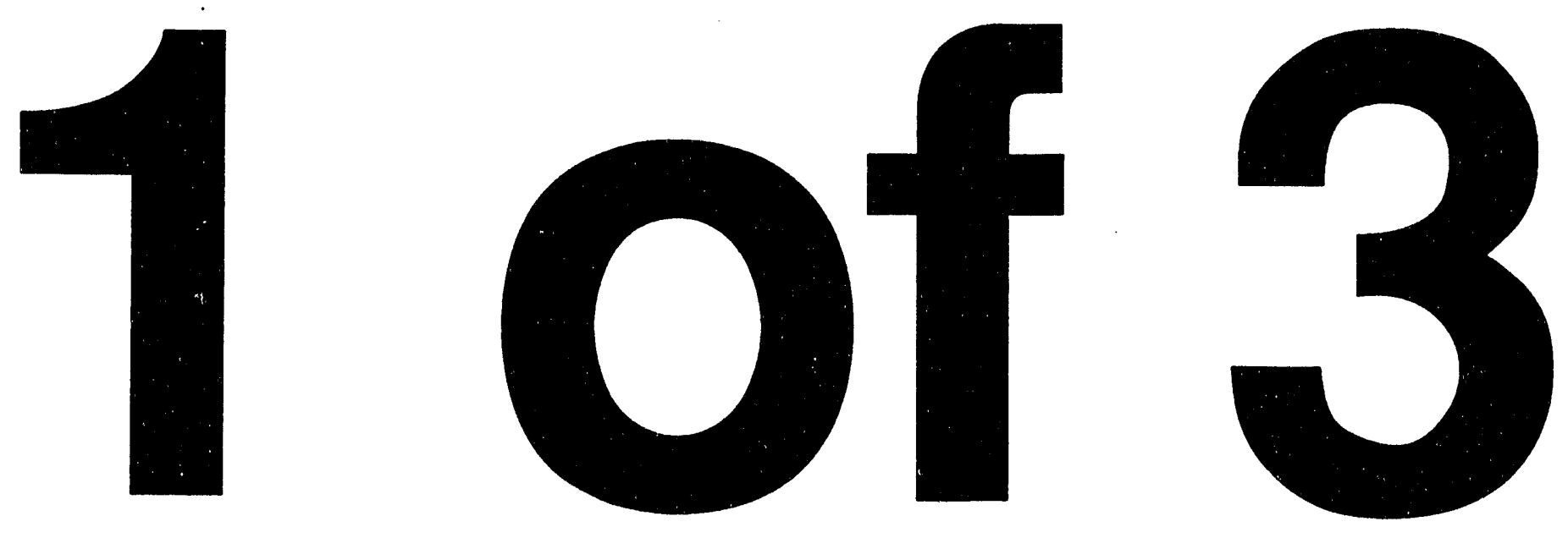
Energy Systems Environmental Restoration Program ORNL Decontamination and Decommissioning Program

\section{Alternatives Evaluation for the Decontamination and Decommissioning of Buildings 3506 and 3515 at Oak Ridge National Laboratory, Oak Ridge, Tennessee}

Date Issued-January 1994

Prepared by Ebasco Services, Inc.

Oak Ridge, Tennessee under contract DE-AC05-91OR21928

Prepared for

U.S. Department of Energy

Office of Environmental Restoration and Waste Management under budget and reporting code EW 20

OAK RIDGE NATIONAL LABORATORY

Oak Ridge, Tennessee 37831-6285 managed by

MARTIN MARIETTA ENERGY SYSTEMS, INC.

for the

U.S. DEPARTMENT OF ENERGY under contract DE-AC05-84OR21400 


\section{CONTENTS}

TABLES $\ldots \ldots \ldots \ldots \ldots \ldots \ldots \ldots \ldots \ldots \ldots \ldots \ldots \ldots \ldots \ldots \ldots$

FIGURES $\ldots \ldots \ldots \ldots \ldots \ldots \ldots \ldots \ldots \ldots \ldots \ldots \ldots \ldots \ldots \ldots \ldots \ldots \ldots \ldots \ldots \ldots$

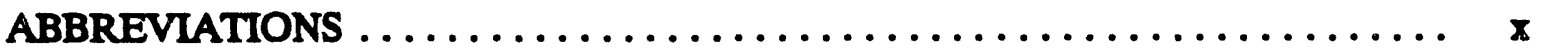

EXECUTTVE SUMMARY $\ldots \ldots \ldots \ldots \ldots \ldots \ldots \ldots \ldots \ldots \ldots \ldots \ldots$ xii

1. INTRODUCTION $\ldots \ldots \ldots \ldots \ldots \ldots \ldots \ldots \ldots \ldots \ldots \ldots \ldots \ldots \ldots$

2. BACKGROUND ............................. 3

2.1 WASTE EVAPORATOR FACIIITY (BUILDNNG 3506) $\ldots \ldots \ldots \ldots \ldots$.

2.2 FISSION PRODUCT PILOT PLANT (BUILDING 3515) $\ldots \ldots \ldots \ldots \ldots \ldots$

3. AVAILABLE TECHNOLOGY ....................

3.1 TECHNOLOGY CATEGORIES $\ldots \ldots \ldots \ldots \ldots \ldots \ldots \ldots \ldots \ldots$

3.2 SELECTED TECHNOLOGIES $\ldots \ldots \ldots \ldots \ldots \ldots \ldots \ldots \ldots \ldots \ldots \ldots$

3.21 Surface Decontamination ......................... 6

3.22 Cutting Techniques ........................ 7

3.23 Concrete Construction ..................... 8

3.24 Excavation ................................ 8

3.25 Below-grade Entombment $\ldots \ldots \ldots \ldots \ldots \ldots \ldots \ldots \ldots \ldots$

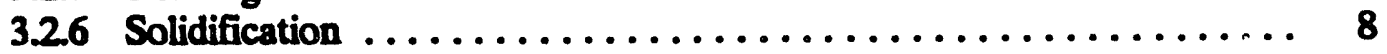

3.2 .7 Remote Processes $\ldots \ldots \ldots \ldots \ldots \ldots \ldots \ldots \ldots \ldots \ldots . \ldots \ldots$

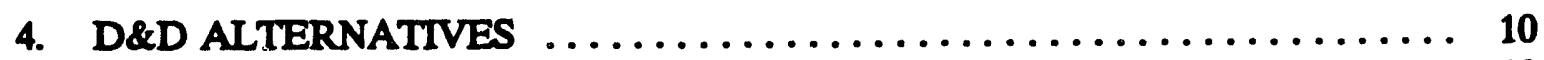

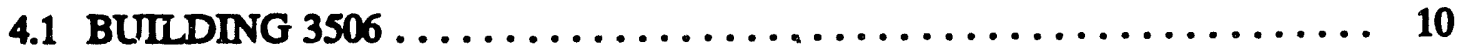

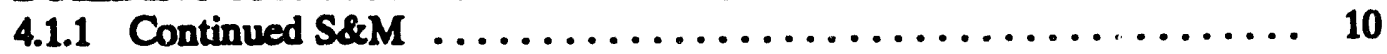

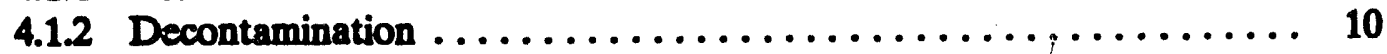

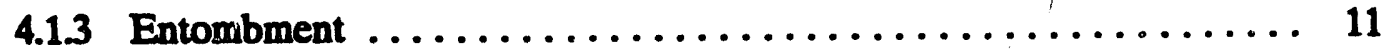

4.1.4 Partial Dismantlement $\ldots \ldots \ldots \ldots \ldots \ldots \ldots \ldots \ldots \ldots \ldots \ldots \ldots \ldots$

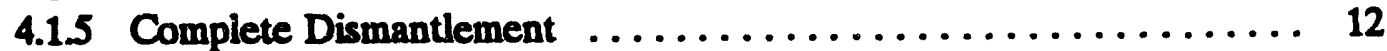

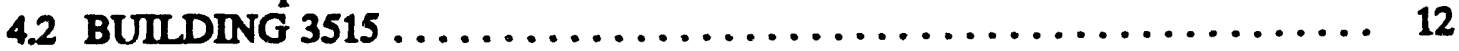

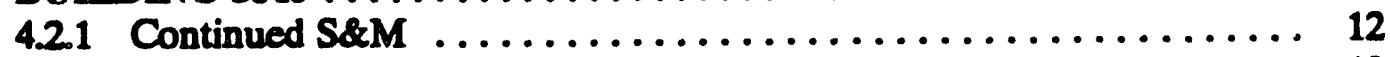

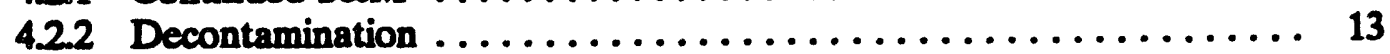

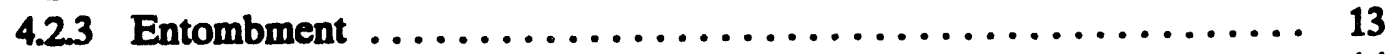

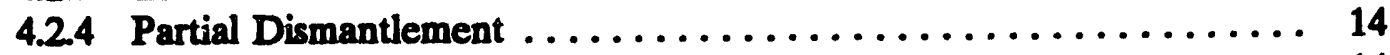

4.2 .5 Complete Dismantlement $\ldots \ldots \ldots \ldots \ldots \ldots \ldots \ldots \ldots \ldots \ldots \ldots$

5. EVALUATION OF ALTERNATIVES $\ldots \ldots \ldots \ldots \ldots \ldots \ldots \ldots \ldots \ldots$

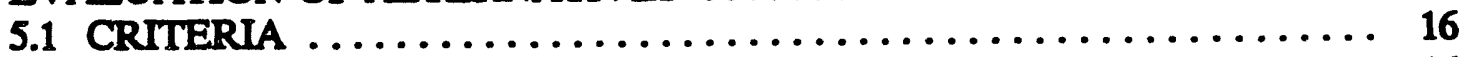

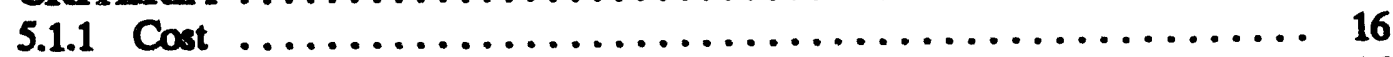

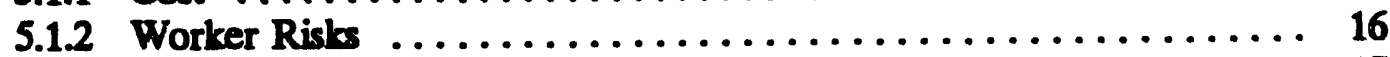

5.1 .3 Reduction of Risks ......................... 17

5.1.4 Environmental Risk $\ldots \ldots \ldots \ldots \ldots \ldots \ldots \ldots \ldots \ldots \ldots \ldots$

5.1.5 Institutional Concerns $\ldots \ldots \ldots \ldots \ldots \ldots \ldots \ldots \ldots \ldots \ldots \ldots \ldots$

5.1.6 Technical Feasibility $\ldots \ldots \ldots \ldots \ldots \ldots \ldots \ldots \ldots \ldots \ldots \ldots \ldots \ldots$ 
5.1.7 Program Compatibility $\ldots \ldots \ldots \ldots \ldots \ldots \ldots \ldots \ldots \ldots \ldots \ldots$

5.1 .8 Waste Management $\ldots \ldots \ldots \ldots \ldots \ldots \ldots \ldots \ldots \ldots \ldots \ldots$

5.2 BUILDNG $3506 \ldots \ldots \ldots \ldots \ldots \ldots \ldots \ldots \ldots \ldots \ldots \ldots \ldots \ldots \ldots$

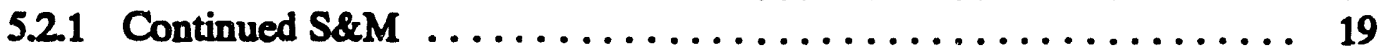

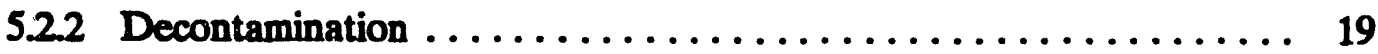

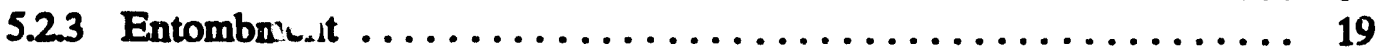

5.2 .4 Partial Dismantlement $\ldots \ldots \ldots \ldots \ldots \ldots \ldots \ldots \ldots \ldots \ldots \ldots \ldots \ldots . \ldots \ldots$

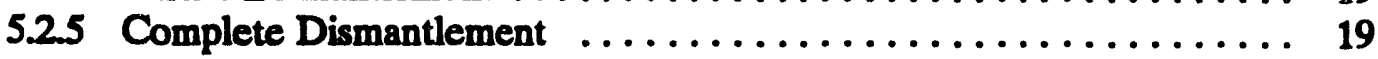

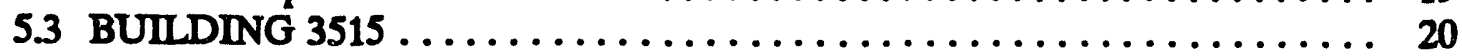

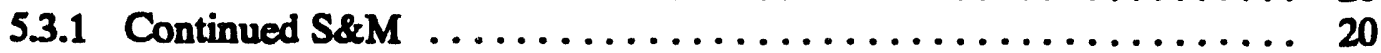

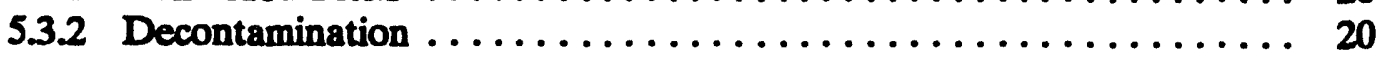

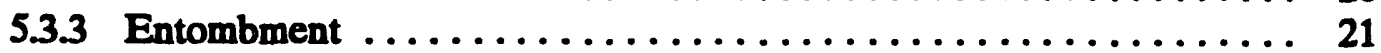

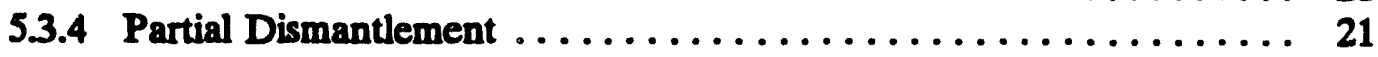

5.3.5 Complete Dismantlement $\ldots \ldots \ldots \ldots \ldots \ldots \ldots \ldots \ldots \ldots \ldots \ldots \ldots$

6. UNCERTAINTIES AND ASSUMPTIONS $\ldots \ldots \ldots \ldots \ldots \ldots \ldots \ldots \ldots \ldots$

6.1 GENERAL UNCERTAINTIES $\ldots \ldots \ldots \ldots \ldots \ldots \ldots \ldots \ldots \ldots \ldots \ldots$

6.2 GENERAL ASSUMPTIONS $\ldots \ldots \ldots \ldots \ldots \ldots \ldots \ldots \ldots \ldots \ldots \ldots \ldots \ldots$

6.3 BUILDING 3506 UNCERTAINTIES $\ldots \ldots \ldots \ldots \ldots \ldots \ldots \ldots \ldots \ldots$

6.4 BUILDING 3506 ASSUMPTIONS $\ldots \ldots \ldots \ldots \ldots \ldots \ldots \ldots \ldots \ldots \ldots \ldots$

6.5 BUILDING 3515 UNCERTAINTIES $\ldots \ldots \ldots \ldots \ldots \ldots \ldots \ldots \ldots \ldots \ldots \ldots . \ldots \ldots$

6.6 BUILDING 3515 ASSUMPTIONS $\ldots \ldots \ldots \ldots \ldots \ldots \ldots \ldots \ldots \ldots \ldots$

7. RECOMMENDED ALTERNATIVES $\ldots \ldots \ldots \ldots \ldots \ldots \ldots \ldots \ldots \ldots$

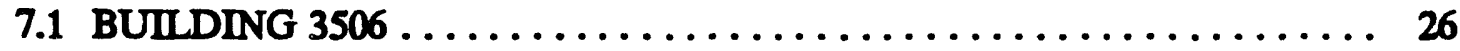

7.2 BUILDING $3515 \ldots \ldots \ldots \ldots \ldots \ldots \ldots \ldots \ldots \ldots \ldots \ldots \ldots \ldots \ldots$

8. COST ESTIMATE_RECOMMENDED ALTERNATTVE ........... 29

8.1 BASIS FOR COST ESTIMATE $\ldots \ldots \ldots \ldots \ldots \ldots \ldots \ldots \ldots \ldots \ldots$

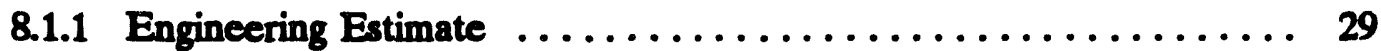

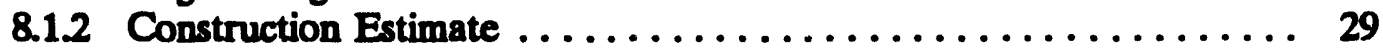

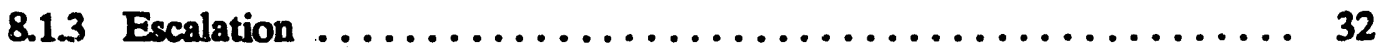

8.1.4 Estimate Assumptions ....................... 32

8.1.5 Contingency in the estimate ................... 35

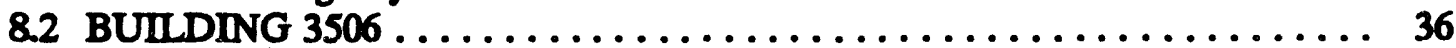

8.3 BUILDING $3515 \ldots \ldots \ldots \ldots \ldots \ldots \ldots \ldots \ldots \ldots \ldots \ldots \ldots$

Appendix A Cost Estimate for Partial Dismantlement of Building 3506 . . . . . . . A-1

Appendix B. Cost Estimate for Complete Dismantlement of Building 3506 . . . . . B-1

Appendix C. Cost Estimate for Complete Dismantlement of Building 3515 . . . . . C-1

Appendix D. Cost Estimate for Partial Dismantlement of Building $3515 \ldots \ldots \ldots \ldots$. . . 


\section{TABLES}

1 Applicable technology categories for D\&D of Building $3506 \ldots \ldots \ldots \ldots \ldots$

2 Applicable technology categories for D\&D of Building $3515 \ldots \ldots \ldots \ldots \ldots \ldots$

3 Semiquantitative evaluation of D\&D alternatives for Building $3506 \ldots \ldots \ldots \ldots 20$

4 Semiquantitative evaluation of D\&D alternatives for Building $3515 \ldots \ldots \ldots \ldots 21$

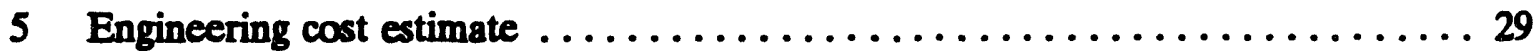

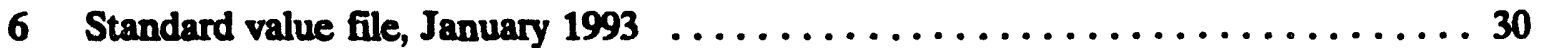

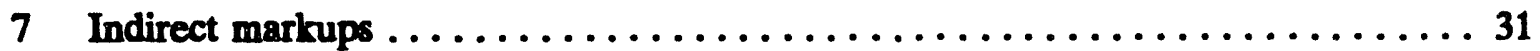

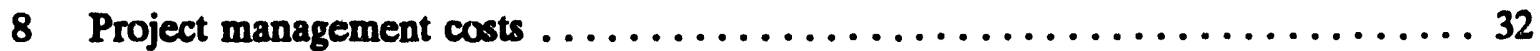




\section{FIGURES}

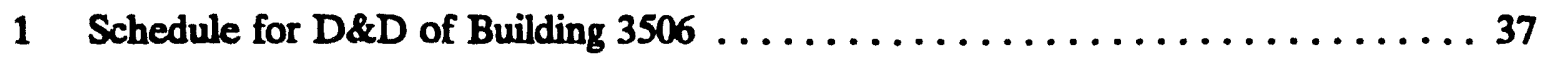

2 Fourth-level project summary by WBS for partial dismantlement of

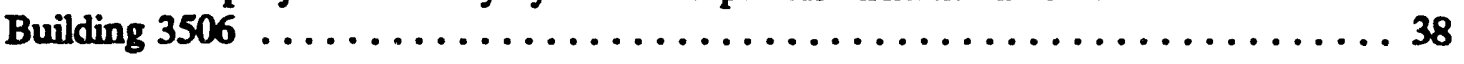

3 Fourth-level project summary by WBS for complete dismantlement

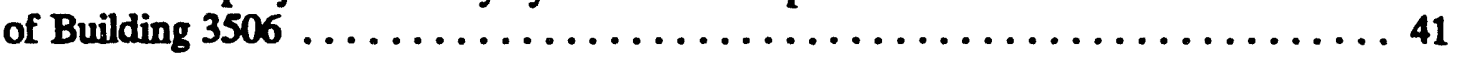

4 Schedule for D\&D of Building $3515 \ldots \ldots \ldots \ldots \ldots \ldots \ldots \ldots \ldots \ldots$

5 Fourth-level project summary by WBS for complete dismantlement

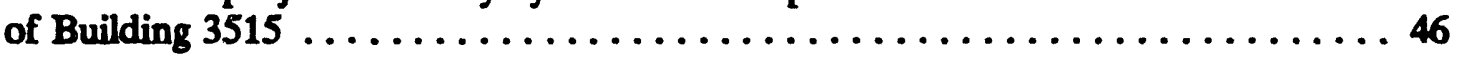

6 Fourth-level project summary by WBS for partial dismantlement of

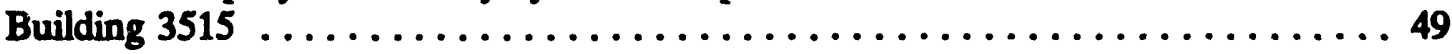




\section{ABBREVIATIONS}

AES

BM

CERCLA

D\&D

DOE

DOE-OR

EPA

ER

FPPP

GAAT

HDPE

LLW

MK-F

MMES

ORNL

OSHA

OU

PPE

PSWBS

S\&M

SFMP

SWSA

WAG

WBS
Automated Estimating System

bill of material

Comprehensive Environmental Response, Compensation, and Liability

Act

decontamination and decommissioning

U.S. Department of Energy

DOE Oak Ridge Field Office

U.S. Environmental Protection Agency

Environmental Restoration

Fission Product Pilot Plant

Gunite and Associated Tanks

high density polyethylene

low-level radioactive waste

MK-Ferguson of Oak Ridge

Martin Marietta Energy Systems, Inc.

Oak Ridge National Laboratory

Occupational Safety and Health Administration

operable unit

personnel protective equipment

Project Summary WBS

surveillance and maintenance

Surplus Facilities Management Program

solid waste storage area

waste area grouping

work breakdown structure 


\section{EXECUTTVE SUMMARY}

This is an alternative evaluation document that records the evaluation process and justification for choosing the alternative recommended for the decontamination and decommissioning (D\&D) of the 3506 and 3515 buildings at the Oak Ridge National Laboratory (ORNL). These two buildings are within the administrative boundary of the Gunite and Associated Tanks (GAAT) Operable Unit (OU) as well as Waste Area Grouping (WAG) 1. Even though D\&D of these two buildings is not being done under the environmental restoration regulations, the schedule should be consistent with the schedule for remediation of the site. Consequently, the start of the D\&D engineering is coincident with the receipt of the Record of Decision for the GAAT OU. The waste materials coming from the D\&D of these buildings will be disposed in Solid Waste Storage Area 6 (at a cost of $\$ 85$ per $\mathrm{ft}^{3}$ ).

The alternatives for the D\&D of the two buildings were: (1) no action (continued surveillance and maintenance), (2) decontamination for free release, (3) entombment in place, (4) partial dismantlement, and (5) complete dismantlement. The no action alternative maintains the status quo for the facility. The free release alternative leaves the building in place cleaned of radioactive and hazardous materials. The entombment alternative leaves the building filled with concrete, thereby isolating any radioactive and hazardous materials present. The partial dismantlement alternative removes the building superstructure, disposes of the radioactive and hazardous materials, and leaves the partially decontaminated below-grade structures for the soils remediation project. The complete dismantlement alternative expands on the partial dismantlement alternative by including the removal of the below-grade structures. Soil remediation is not included in any of the alternatives.

The recommended alternative for the D\&D of Building 3506 is partial dismantlement at an estimated cost of $\$ 936,000$ in escalated dollars. This alternative is recommended, because the below-grade concrete may remain in place in the chosen alternative for the below-grade remediation effort. As a comparison to the partial dismantlement of Building 3506, the cost estimate for complete dismantlement is $\$ 1,384,000$. This cost is $\$ 448,000$ more than the cost for the recommended alternative. The recommended alternative for the D\&D of Building 3515 is complete dismantlement at an estimated cost of $\$ 3,733,000$ in escalated dollars. This alternative is recommended, because the soils below the foundation of the 3515 building are highly contaminated, and removing the foundation in the D\&D project resulis in lower overall worker risk, costs, and improved post-D\&D site conditions. As a comparison, the cost for partial dismantlement of Building 3515, leaving the decontaminated slab in place, is estimated to be $\$ 3,757,000$. This is $\$ 24,000$ more than the recommended cost because of the decontamination of the remaining slab, even though handling and disposal costs for the material are left to other remediation efforts.

A further recommendation is to revise these cost estimates after the conclusion of the ongoing characterization study. The results of the characterization of the two buildings is expected to change some of the assumptions and resolve some of the uncertainties in the development of these estimates. 


\section{INTRODUCTION}

This alternatives evaluation is a decision document that records the evaluation process and justification for choosing the alternatives to be implemented for the decontamination and decommissioning (D\&D) of the Waste Evaporator Facility (Building 3506) and the Fission Product Pilot Plant (Building 3515). The two buildings are located within the administrative boundary of the Gunite and Associated Tanks (GAAT) Operable Unit (OU). Because of the location of the two buildings, D\&D of the buildings will be integrated with the remediation projects. This integration is accomplished by constraining the Title I/II engineering to the receipt of the Record of Decision, which is scheduled for November 5, 1996. Even though these buildings are included in the GAAT OU, there is no intention to imply that D\&D of these buildings is regulated by the Comprehensive Environmental Response, Compensation, and Liability Act (CERCLA).

D\&D of the two buildings is within the purview of the Oak Ridge National Laboratory (ORNL) D\&D program and must adhere to the goals and guidelines of that program. Specifically, the goals of the D\&D program as they apply to the 3506 and 3515 buildings are to (1) achieve final disposition of the facilities-not an interim activity until final disposition can be achieved, (2) maintain compatibility with the Environmental Restoration (ER) Program and ER activities for Waste Area Grouping (WAG) 1 and the GAAT OU, and (3) protect human health and the environment. To accomplish these goals, five D\&D alternatives were identified for evaluation. The tive alternatives include (1) a no action alternative [continued surveillance and maintenance (S\&M)], (2) a decontamination alternative for leaving the structures in place, (3) an entombment inplace alternative, including both horizontal and vertical controls, (4) a partial dismantlement alternative, which dismantles the above-grade structures and caps below-grade structures, and (5) a complete dismantlement alternative. The five D\&D alternatives are identified in this document as continued S\&M, decontamination, entombment, partial dismantlement, and complete dismantlement, respectively.

The evaluation of the alternatives will include eight criteria. The criteria include (1) costs; (2) D\&D worker risks during D\&D; (3) environmental risks after D\&D; (4) the overall reduction of risks to human health of the ORNL workers and general population as a result of the D\&D operations; (5) institutional concerns and requirements; (6) program compatibility with the ER GAAT OU activities; (7) technical feasibility; and (8) waste management, minimization, and management. A semiquantitative evaluation of the five alternatives was performed to recommend the best alternative for each building. Cost estimates for the recommended alternative and the other dismantlement alternative for each building are provided to a level of detail consistent with the data available from the provided documentation and visual observation of the buildings.

This document is divided into eight sections. Section 1 is the introduction and provides information on the document and its organization. Section 2 presents the background information on the two buildings. Section 3 describes the technologies available for the D\&D alternatives for these buildings and identifies any technologies that represent limiting factors for the required D\&D tasks. Section 4 presents descriptions of the five D\&D alternatives evaluated for each building. Section 5 presents the evaluation criteria and results of the semiquantitative evaluation of the five D\&D alternatives. The uncertainties and assumptions used for the evaluation of the D\&D alternatives are discussed in Sect. 6. The recommended 
alternatives for D\&D of each building are identified in Sct. 7, while Sect. 8 contains the basis of the cost estimate and the estimates for the recommended alternatives. The Appendixes include the detailed cost estimates for the recommended alternatives. 


\section{BACKGROUND}

This section provides a brief description of the 3506 and 3515 buildings, their operating history, an overview of their inclusion into the GAAT OU, and their present condition with regard to their D\&D. The first section describes the Waste Evaporator Facility, while the second section describes the Fission Product Pilot Plant.

Both buildings are within the administrative boundary of the GAAT OU. The soil within the GAAT OU and surrounding the two buildings is contaminated from various operations at ORNL. Therefore, the soils surrounding and beneath the buildings are included in a soils remediation project. The extent and magnitude of the soil contamination may require additional operational concerns during and after D\&D of the two buildings to continue to safeguard human bealth.

\section{WASTE EVAPORATOR FACIITY (BUILDING 3506)}

The Waste Evaporator Facility (Building 3506) is located at the ORNL Bethel Valley site. It is situated on the west side of the GAAT OU south tank farm, near the intersection of Central Avenue and Third Street. The building is a split-level structure with overall dimensions of approximately $32 \mathrm{ft} \times 23 \mathrm{ft}$. On the east side of the building is a wood-frame operating gallery. The west side of the building is the hot cell area. About half of the hot cell area is below-grade. In addition to the below-grade cell, there are three valve pits on the north end of the building and a single pit on the west side of the building.

This building was constructed in 1949 and was modified throughout its operational life. It originally housed the first liquid waste evaporator at ORNL, which operated until 1954. After this, the building was extensively decontaminated, and an experimental radioactive waste incinerator was housed in the cell area. In 1959, equipment for rare earth separation was installed in the building. After removal of equipment from the operating gallery and cell areas and decontamination of the interior of the building, the operating gallery was used as a dressing room for workers in the tank farm area.

In 1976, Building 3506 was transferred into the Surplus Facilities Management Program (SFMP), and routine S\&M has been performed. Routine S\&M has included reroofing of this building. Building 3506 is now in the D\&D program.

The building is currently expected to be relatively free of radioactive contamination; specific contamination levels assumed are documented later. Both an interior survey of the operating gallery and prior surveys of the cell interior show that there is no transferable contamination. The only contaminated areas are associated with the remaining embedded piping.

This building is within the administrative boundary of the GAAT OU, and, therefore, the 3506 building D\&D activities and the remediation of the tanks and the soils within the GAAT OU must be coordinated to prevent conflict between all on-site efforts. 


\section{FISSION PRODUCT PIIOT PLANT (BUILDING 3515)}

The Fission Product Pilot Plant (FPPP), Building 3515, is located on the east side of the GAAT OU south tank farm, near the intersection of Central Avenue and Fourth Street. The building contains two rooms with solid masonry block walls shielding the process equipment. In addition, lean-tos were constructed to house the operating area for the processes and later removed. Currently, concrete shieiding surrounds the entire structure, and all doorways are sealed.

This building was built in 1948 and was modified throughout its operational life. The original facility in 1948 consisted of a concrete pad with tanks and a tent surrounding the shield blocks. In 1950-1951, construction of a hot cell was begun with 18-in.-thick solid masonry block walls and a 2-ft-thick reinforced concrete roof. Lean-to buildings contained the operating area. The FPPP was used to extract radioisotopes of ruthenium, strontium, cesium, cerium, and other elements from liquid waste, which came from ORNL operations and Chalk River cleanup operations in Canada. Operations in this facility resulted in severe contamination of the interior surfaces caused by the practice of overflowing the piping and vessels with purge liquids for decontamination to allow entry for work. The drain from this building contained highly radioactive material, resulting in the evacuation of the operating area because of high radiation fields from the drain. It is known that this line leaked and that the soil was extensively contaminated.

In 1976, Building 3515 was transferred into the SFMP for eventual D\&D. Since then, routine S\&M has been performed, including extensive roof repairs. Building 3515 is now in the D\&D program.

The building interior is currently inaccessible. because it is completely enclosed by an added concrete shield wall. A stainless steel roof was installed to prevent leakage of rainwater into the building. No information is available on the equipment or systems still located inside the building. A substantial amount of fission products is located within the building; however, because of decay, the major radionuclides remaining are ${ }^{137} \mathrm{Cs}$ and ${ }^{90} \mathrm{Sr}$. As expected, only ${ }^{137} \mathrm{Cs}$ has been detected from the external radiation measurements. There is also extensive contamination of the soil under and around this building because of the leaky drain line. On the north side of this building is a small valve pit which contains valves and controls.

This building is within the administrative b sundary of the GAAT OU. Therefore, the 3515 building D\&D activities and the remediation of the tanks and soils within the GAAT OU must be coordinated to prevent conflict between all on-site efforts. 


\section{AVAILABLE TECHNOLOGY}

This section describes the technologies available for use in the five D\&D alternatives for the 3506 and 3515 buildings. The first section identifies applicable categories of technologies used in each alternative. The second section briefly describes the various technologies in each category and explains why specific technologies were selected for the D\&D project.

\subsection{TECANOLOGY CATEGORIES}

The technology categories identified for the five D\&D alternatives for the 3506 building are presented in Table 1.

Table 1. Applicable technology categories for D\&D of Building 3506

\begin{tabular}{ll}
\hline DED alternative & Technolos categories \\
\hline Continued S\&M & None \\
Decontamination & Surface Decontamination \\
Entombment & Concrete Construction \\
& Excavation \\
& Below-grade Entombment \\
Partial Dismantlement & Surface Decontamination \\
& $\begin{array}{l}\text { Cutting } \\
\text { Solidification }\end{array}$ \\
Complete Dismantlement & Surface Decontamination \\
& Cutting \\
& Solidification \\
& Excavation \\
\hline
\end{tabular}

The technology categories identified for the five D\&D alternatives for the 3515 building are presented in Table 2. 
Table 2 Applicable technology categories for D\&D of Building 3515

\begin{tabular}{ll}
\hline D\&D alternative & Technology categories \\
\hline Continued S\&M & None \\
Decontamination & Surface Decontamination \\
& Remote Processes \\
& Cutting \\
& Concrete Construction \\
Entombment & Excavation \\
& Below-grade Entombment \\
& Surface Decontamination \\
Partial Dismantlement & Cutting \\
& Remote Processes \\
& Solidification \\
& Surface Decontamination \\
Complete & Cutting \\
Dismantlement & Remote Processes \\
& Solidification \\
& Excavation \\
\hline
\end{tabular}

\section{SEI ECTED TECHNOLOGIES}

The various available technologies and those that were selected from each category for the D\&D alternatives are described in limited detail below.

\subsection{Surface Decontamination}

The only technology selected for surface decontamination of the surfaces of either of the buildings is scabbling. Scabbling (also known as scarifying) is a mechanical decontamination technique used primarily on steel and concrete surfaces. The scabbler tool uses pneumatically operated piston heads positioned to strike the surface being decontaminated with enough force to physically remove some of the surface material. For these projects, scabbling will remove approximately one quarter inch of concrete from the concrete surfaces. For the steel surfaces, scabbling will remove the paint layers, surface oxidation, and a thin film of the metal surface. The removal of surface and embedded contamination is assumed to be complete after one treatment with the scabbling tool. In reality, a surface contamination survey will be performed to certify that sufficient amounts of contamination have been removed. Areas that are not sufficiently cleaned would have the scabbling treatment repeated. The scabbling decontamination is used most successfully on poured concrete surfaces. Scabbling of concrete block is not included in this application because of the possibility of crumbling of the block, causing an increase in the disposal volume. However, scabbling is currently being performed successfully on concrete block on Building 3505 (in the immediate vicinity), and other D\&D projects may use this technique. 
Several other technologies for surface decontamination were examined and rejected for various reasons. Microwave scabbling was rejected for being too recent and requiring further development before it is commercially viable. Dry ice blasting has not been proven on surfaces for other than surface films such as paint. Removal at depth for dry ice may not be currently available or technically feasible. Abrasive blasting techniques use a type of grit which would become contaminated and would require disposal as secondary waste. Other generators of secondary waste include chemical stripping means. Abrasive blasting of concrete block would be attempted, if the cost of such decontamination would result in offsetting costs in the disposal of the contaminated materials, including the abrasive material. This is not expected to be the case with the anticipated disposal landfills being estimated for these two D\&D projects.

\section{Cutting Techniques}

Cutting apart the equipment and the buildings is the selected technique for dismantlement. Metallic cutting uses hydraulic shears and concrete cutting uses any of four different techniques. Other techniques for cutting that were examined and rejected include plasma arc cutting and ultra-high-pressure water jet cutters. Plasma arc cutters for cutting metals were rejected for use in Building 3515 because of fire hazards and the tight tolerances required for effective cutting. These tolerances are not considered achievable under the remote handling conditions in the 3515 building. Ultra-high-pressure water jet cutters were rejected because of the long and expensive set-up required for each different cut.

\section{Hydraulic shear:}

Cutting of the equipment, piping, and nonconcrete structural materials will be done by hydraulic shears, usually mounted on a backhoe-type of vehicle. The hydraulic shears will cut through the materials, and the remains will be picked up by clamshell grippers on a small crane. Hydraulic shears are used preferentially to any other cutting operation, because the shears are only mechanical, and their operation will not cause sparking nor generate heat that could cause fires.

\section{Concrete cutters}

Cutting of the concrete structure will be done using a combination of wall saws, wire saws, hydraulic hammers, or expansive grout. The first two techniques will segment the concrete walls, floors, or pits into manageable sized pieces without rubbling. These pieces can then be packed into disposal boxes at high packing factors. The last two techniques break the concrete into smaller debris, which may be quicker than the cutting operations. All techniques are described below. All of the techniques, except the expansive grout, generate dust which must be collected, typically by a water spray, which is then vacuumed.

Wall saw. Wall saws are diamond-studded circular blades that abrasively cut a kerf through the concrete. The blades also cut through reinforcing rods. The depth of cut is limited to slightly less than the radius of the blade.

Diamond wire saw. A diamond wire saw uses a diamond-studded wire cable which is pulled at high speed and high tension through predrilled holes, producing a clean cut in the concrete. The only limit to the cut shape or size is that limited to accessing the required guide holes. 
Hydraulic hammer. A mobile, remotely controlled hydraulic hammer can be used to break apart the concrete walls, floor slab, or below-grade pit. The hydraulic hammer possesses a high-energy and high blow rate, which results in the efficient removal of areas of concrete. However, any rebar in the concrete must be cut by other methods. In addition, the resulting rubble may require additional disposal volume, unless the packing factor of the debris can approach the packing factor of the intact cutting techniques described above.

Expanaive grout. An expansive grout can be used to break apart large or oddly shaped concrete foundations. Guide holes are drilled in a given pattern and injected with expansive grout, causing the concrete to break apart in predictable shaped pieces which can be handled easily. However, any rebar spanning the cracking must be cut by other methods.

\section{Concrete Construction}

Standard concrete construction techniques will be used for the entombment of the above-grade structures.

\subsection{Excevation}

Soil excavation by tools such as backhoes, trench diggers, and others is employed when the soil around the concrete structure must be removed before the concrete structure is removed. These tools will remove the soil, allowing access to the concrete for cutting, cleaning, or removal.

\section{Below-grade Entombment}

Below-grade entombment requires that all volumes of the contaminated structure be isolated from the environment. This means that all of the below-grade structure must be enclosed with material that will prevent migration of the contamination from the structure into the outside environment. A grout material is specified to be injected under and around the below-grade structure to prevent the migration of the contaminants. This task is comparable to encapsulating the entire below-grade structure.

Entombment beneath the building foundation will be accomplished by first excavating trenches on opposite sides of the building. The depth of the trenches will be $2-4 \mathrm{ft}$ below the bottom of the lowest extent of the foundation. Horizontal holes will be drilled for the installation of 2-in.-diameter pipes on 5-ft centers, extending the full length of the building. Perforated piping will be installed with both ends extending into the trench. Grout is forced into the perforated pipe under pressure, which then spreads out from the pipe to fill the underside of the slab with a controlled volume of grout.

\section{Solidification}

In some cases, wastes may be required to be solidified before their ultimate disposal. This would occur for wastes that contain a high concentration of finely divided materials, such as the debris generated in the concrete cutting activity. Solidification agents that can be used are concrete, grout, or epoxy. The choice will depend on the chemical and physical characteristics of the waste as well as the disposal form required. 


\section{Remote Processes}

Remotely operated processes are required when the radiation field in the work area is more than that allowed for human presence. For much of the work on Building 3515, remotely operated equipment must be used. The three basic types of remotely operated items are described below. These are (1) sensors, (2) tools, and (3) transporters. Each type of device will be mounted on its own remotely controlled robotic arm.

\subsubsection{Remote sensors}

Remote sensors include all of the items required to visualize what is within the high-radiation field. This includes cameras and lights, instruments for measuring radiation, and other measurement or detection instruments. A robotic arm-mounted camera and lights will be used to inspect the areas in which the radiation field prohibits human entry. Radiation survey instruments would also be included on the robotic arm carrying the camera for viewing the areas within the high-radiation field. The survey instruments would allow detection of the highest contamination areas and provide information needed for the removal, packaging, and disposal of the material contained within the high-radiation field. Any other remote-sensing instruments that might be required for work within the high-radiation field would be mounted on this robotic arm.

\section{Remote tools}

All of the remote tools required will be mounted on a robotic arm that will do all of the tooled activities. Some of the tools that might be required are shears for cutting, concrete wall saw for sawing, scabbling tool for surface decontamination, drills for drilling guide holes for the wire saw, and vacuums for removing debris generated by the cutting operations.

\section{Remote tranoporters}

A single robotic arm or a remotely operated crane will be used to remove the material cut up by the remote tools. The arm will have sufficient lifting capacity to lift the largest items within the high-radiation field and to move them sufficiently to place them into the disposal boxes after any cutting or removing has been accomplished. 


\section{D\&D ALTERNATIVES}

The D\&D alternatives for the 3506 and 3515 buildings range from "no action" to complete demolition of the building. Each of the alternatives for the two buildings are identified and described to the level of detail required to support the evaluation process in the following two sections.

\subsection{BUII.DING 3506}

The five alternatives for the D\&D of Building 3506 are (1) continued S\&M, (2) decontamination, (3) entombment, (4) partial dismantlement, and (5) complete dismantlement. Each of these alternatives is described below.

\subsubsection{Continued SeM}

This alternative is considered to be the status quo for the D\&D of the building; therefore, it is the appropriate "no action" alternative required for all DOE alternative evaluations. Continued S\&M for the foreseeable future would include whatever periodic surveys are required to show that contained radioactivity, if any, has not migrated away from the building and is not posing a hazard to the workers or to the general public. After the period of continued S\&M, to comply with the goal of the ORNL D\&D program, the 3506 building would undergo one of the other four alternatives for ultimate disposition. Building 3506 has previously undergone decontamination activities, and no radioactive process equipment remains in the building. Therefore, little remaining radioactivity is expected; consequently, migration away from the building is considered improbable.

\subsubsection{Decontamination}

This alternative, commonly called "free release," involves the final decontamination of the building, verification that the building is free of radioactive materials, and the release of the building for unrestricted use as any other type of facility. Building 3506 has previously undergone decontamination activities and presumably has little remaining radioactivity. The steps in this alternative include inventory and characterization, D\&D operations, and a final release survey.

The first task in this alternative would be to perform an inventory of the remaining material within the building. After the material inventory is complete, a thorough characterization of the building would be performed to document which building surfaces are free of contamination and to identify remaining areas that are still contaminated. D\&D operations would include equipment removal, surface decontamination, and structural refurbishment. Equipment removal operations include removing any remaining equipment and surveying it to determine its level of contamination. Equipment decontamination would be attempted only if the equipment is salvageable and the decontamination effort is not too cost-intensive. Otherwise, the equipment would be packaged along with other low-level radioactive waste for ultimate disposal in a radioactive low-level waste (LLW) landfill.

Surface decontamination operations would only be required if the initial characterization survey identified areas that remained contaminated after the previous decontamination efforts. 
Typical surface decontamination efforts would include scabbling of the concrete, removal and disposal of contaminated wood, and replacement of porous contaminated materials. The pits associated with the cell in this building would require decontamination of the internal surfaces as well as verification that leakage of contamination did not enter the soils surrounding the pit. The roof will probably have to be removed and replaced because of its level of contamination (contamination from other sources), and major portions of the building would also require recons'ruction. In addition, any penetrations into the building would be sealed.

After completion of all D\&D operations, a final verification survey would be performed to document that the entire building is free of radioactive and hazardous materials and that it can be released for unrestricted use. Upon the successful completion of the final survey and verification, the building's radiological control area access restrictions would be removed. However, because of the contamination of the soils around the building (as described in Sect. 2), the building probably would not be released for unrestricted use until the conclusion of the soils remediation project, if then. Structural refurbishment operations would be required to replace any essential utilities or structure removed during the decontamination efforts. These include the electrical; lighting; heating, ventilation, and air conditioning (if any); roof; walls; or foundation to the building, including the pits. After the building is released, any costs for its final demolition would not be part of the D\&D program.

\subsection{Entombment}

This alternative is precisely the same alternative that the U.S. Nuclear Regulatory Commission defines as "entomb." This alternative takes the existing facility and backfills it completely with concrete to produce a monolith that contains all radioactive or hazardous contaminants and prevents their release to the environment. All areas, including below-grade pits, would be entombed with sufficient confidence that radioactive or hazardous materials would not migrate into the environment, either from above-grade or from below-grade structures. This alternative might allow contaminated materials to be disposed of in the building using the entombment method.

\subsubsection{Partial Diamantlement}

This alternative completely removes the above-grade structure and covers the below-grade structures for inclusion in the soils remediation task. Building 3506 has previously undergone decontamination activities and presumably has little remaining radioactivity. The steps in this alternative include inventory and characterization, equipment removal, decontamination, demolition, and backfilling.

The first task in this alternative would be to perform an inventory of the remaining material within the building. After the material inventory is complete, a thorough characterization of the building would be performed to document which building surfaces are free of contamination and to identify remaining areas that are still contaminated. Equipment removal would be followed by surface decontamination of up to $50 \%$ of the interior surfaces inside the pits. The fines would be solidified and disposed of as LLW. Equipment removal operations include removing any remaining equipment and surveying it to determine its level of contamination. Equipment decontamination would be attempted only if the equipment is salvageable and the decontamination effort is not too cost-intensive. Otherwise, the equipment would be packaged along with other LLW for ultimate disposal in a LLW landfill. Surface decontamination efforts for equipment would only be expended if the cost of such 
efforts would result in offsetting costs in the disposal of the contaminated materials. This is not expected to be the case with the anticipated disposal landfills being used for this project.

The above-grade portions of the building would be demolished using conventional means. Other than normal health physics (HP) monitoring, contamination control procedures will not be necessary during demolition activities. Backfilling operations would include filling the below-grade cell volume with concrete rubble removed from the walls, covering it with an impermeable plastic liner, backfilling with soil, grading, and grass seeding for appearance. Any radioactivity or hazardous constituents remaining in the soils around the pits would be remediated by the soils remediation efforts. Therefore, no final release surveys are to be performed on the site of the demolished building.

\subsubsection{Complete Diemantlement}

This alternative expands on the partial dismantlement alternative by including the removal of the below-grade portions of Building 3506. The additional step in this alternative is removal of below-ground foundation materials. The first task in this alternative would be to perform an inventory of the remaining material located within the building. Equipment removal would be followed by surface decontamination (if appropriate). The fines would be solidified and disposed as LLW. Equipment removal operations include removing any remaining equipment and surveying it to determine its level of contamination. Equipment decontamination would be attempted only if the equipment is salvageable and if the decontamination effort is not too cost-intensive. Otherwise, the equipment would be packaged along with other $L L W$ for ultimate disposal in a $L L W$ landfill. Surface decontamination efforts for equipment would only be expended if the cost of such efforts would result in offsetting costs in the disposal of the contaminated materials. This is not expected to be the case with the anticipated disposal landfills being used for this project.

The above-grade portions of the building would be demolished using conventional means. Other than normal HP monitoring, contamination control procedures will not be necessary during demolition activities. The pits would be excavated. Contamination control is expected for below-grade activities. Finally, the area would be lined with an impermeable plastic liner, backfilled with soil, graded, and grass seeded for appearances. No final release survey would be perform ad because the soils are part of the ER effort.

\section{BUIIDING 3515}

The five alternatives for the D\&D of Building 3515 are (1) continued S\&M, (2) decontamination, (3) entombment, (4) partial dismantlement, and (5) complete dismantlement. Each of these alternatives are described below.

\section{Continued SeM}

This alternative is considered to be the status quo for the D\&D of the building; therefore, it is the appropriate "no action" alternative required for all DOE alternative evaluations. This alternative is also consistent with the U.S. Nuclear Regulatory Commission's "SAFSTOR" option for D\&D. Continued S\&M for the foreseeable future would include whatever periodic surveys are required to show that the contained radioactivity has not migrated away from the building and is not posing a hazard to the workers or to the general 
public. Continued maintenance would be required to maintain the integrity of the shielding. This alternative may be useful because the radioactive hazard continually decreases. However, because the half-lives of the dominant radioisotopes are about $\mathbf{3 0} \mathrm{yr}$, many decades will be required to substantially reduce radiation exposure to D\&D workers. After the period of continued S\&M, to comply with the goal of the ORNL D\&D program, the 3515 building would have to undergo one of the other four alternatives for ultimate disposition.

\section{Decontamination}

This alternative, commonly called "free release," involves the final decontamination of the building, verification that the building is free of radioactive materials, and release of the building for unrestricted use as any other type of facility. The steps in this alternative include initial characterization, D\&D operations, and a final release survey.

The first task in this alternative would be to perform an inventory of the remaining material within the building. The characterization of the building would consist of sufficient measurements to locate the sources of high radiation in the building. D\&D operations would include equipment removal, surface decontamination, and structural refurbishment. Equipment removal operations include the removal of all equipment. Equipment decontamination would be attempted only if the equipment is salvageable and if the decontamination effort is not too cost-intensive. Otherwise, the equipment would be packaged along with other LLW for ultimate disposal in an LLW landfill. Surface decontamination operations are required for all the interior surfaces of Building 3515. Typical surface decontamination efforts would include scabbling of the masonry block and removal of any other contaminated structural material. The sampling station associated with the cell in this building would require decontamination of the interior surfaces as well as verification that leakage of contamination did not enter the soils surrounding the sampling station. The roof would probably have to be removed and replaced because of its level of contamination.

After the completing all D\&D operations, a final verification survey would be performed to document that the entire building is free of radioactive or hazardous materials and that it can be released for unrestricted use. Upon the successful completion of the final survey and verification, the building's radiological control area access restrictions would be removed. However, because of the contamination of the soils around the building (as described in Sect. 2), the building would probably not be released for unrestricted use until after the conclusion of the soils remediation project, if then. Structural refurbishment operations would be required to replace any required utilities or structure removed during the decontamination efforts. These include the electrical; lighting; heating, ventilation, and air conditioning (if any); roof; walls; or foundation to the building, including the sampling station. After the final release survey, any costs for its final demolition would not be part of the D\&D program.

\section{Entombment}

This alternative is precisely the same alternative that the U.S. Nuclear Regulatory Commission defines as "Entomb." This alternative takes the existing facility and backfills it completely with concrete to produce a monolith which contains all radioactive or hazardous contaminants and prevents their release to the environment. All areas, including the sampling station, would be entombed with sufficient confidence that radioactive or hazardous materials would not migrate into the environment from either above-grade or below-grade structures. 


\subsection{Partial Diamantlement}

This alternative completely removes the above-grade structure and covers the below-grade structures for inclusion in the soils remediation task. The steps in this alternative include initial characterization, dismantlement, and backfilling.

The first task in this alternative would be to perform an inventory of the remaining material within the building. The characterization of the building would consist of sufficient measurements to locate the sources of high radiation in the building. Dismantlement operations would include equipment removal, surface decontamination, and building demolition. Eyuipment removal operations include the removal of all equipment. Equipment decontamination would be attempted only if the equipment is salvageable and if the decontamination effort is not too cost-intensive. Otherwise, the equipment would be packaged along with other LLW for ultimate disposal in an LLW landfill. Surface decontamination efforts would only be expended if the cost of such efforts would result in offsetting costs in the disposal of the contaminated materials or significantly decreased requirements for access control during demolition. This is not expected to be the case with the anticipated disposal landfills being used for this project. The entire building would be demolished using appropriate contamination control procedures as well as appropriate shielding to protect the D\&D workers and general ORNL population from the radiation shine from the remaining structure. The top surface of the concrete pad would be decontaminated to remove the bulk of the radioactive or hazardous contamination.

Backfilling operations would include lining the sampling station and concrete with an impermeable plastic liner, backfilling the sampling station and pad with soil, grading, and grass seeding for appearances. The remaining radioactivity or hazardous constituents in the sampling station or in the soils under the building would be remediated by the soils remediation efforts. Therefore, no final release surveys are to be performed on the site of the demolished building.

\section{Complete Dismantlement}

This alternative expands on the previous alternative by including the removal of the concrete pad and sampling station of Building 3515. The steps in this alternative are initial characterization, dismantlement, and removal of below-ground materials.

The first task in this alternative would be to perform an inventory of the remaining material within the building. The characterization of the building would consist of sufficient measurements to locate the sources of high radiation in the building. Dismantlement operations would include equipment removal, possible surface decontamination, and building demolition. Equipment removal operations include the removal of all equipment. Equipment decontamination would be attempted only if the equipment is salvageable and if the decontamination effort is not too cost-intensive. Otherwise, the equipment would be packaged along with other $L L W$ for ultimate disposal in an $L L W$ landfill. Surface decontamination efforts would only be expended if the cost of such efforts would result in offsetting costs in the disposal of the contaminated materials or significantly decreased requirements for access control during demolition. This is not expected to be the case with the anticipated disposal landfills being used for this project. The entire building would be demolished using appropriate contamination control procedures as well as appropriate shielding to protect the 
D\&D workers and general ORNL population from the radiation shine from the remaining structure. The concrete pad and sampling station would be excavated.

Finally, the area would be lined with an impermeable plastic liner, backfilled with soil, graded, and grass seeded for appearances. The soils would be left for the soils remediation effort and no final verification survey would be performed. 


\section{EVALUATION OF ALTERNATIVES}

This section describes the evaluation criteria by which the five D\&D alternatives for the buildings were semiquantitatively evaluated. The results of the evaluation for each building are tabulated, and important items that contributed to the resultant ranking are described. The first section explains the evaluation criteria. Section 5.2 presents the evaluation of the alternatives for the 3506 building, and Section 5.3 presents the evaluation of the alternatives for the 3515 building.

\section{S.1 CRIIERIA}

The alternatives for the D\&D of the buildings are evaluated according to eight criteria. These criteria are (1) cost, (2) worker risks, (3) reduction of risks, (4) environmental risks, (5) institutional concerns, (6) technical feasibility, (7) program compatibility, and (8) waste management. Each of these criteria is detailed below, along with the range of assessments for each criterion.

All criteria are assessed in a semiquantitative manner wiw ratings from one to five. The best situation is assessed as a "five" and the worst situation is assessed a "one." Some examples of the ratings are provided in the descriptions below.

\subsubsection{Cost}

The overall cost of the D\&D alternatives is semiquantitatively assessed. The assessment of the cost includes design, construction, operation, waste treatment and packaging, and waste disposal. In general, for each building, the design cost would remain essentially the same over the four alternatives that perform D\&D operations; therefore, the design cost does not affect the rating order for cost. The D\&D operations of construction and operation as well as waste disposal would vary among the alternatives. Thus, the major cost factors affecting the ordering of the alternatives are the D\&D operations and the waste disposal. The D\&D alternative judged to be the least expensive is rated a five, while the most expensive is rated a one. The other three alternatives are rated accordingly. If an actual cost estimate were done on each of the alternatives, their rating order might change.

\subsection{Worter Rivls}

The risk to the workers in the D\&D alternative is semiquantitatively assessed for this criterion. Items considered in the evaluation of worker risks include industrial safety, radiation exposure, and other risks typical of construction and trenching activities in a radiation environment. The total risk is estimated by examining the major components of the D\&D alternative and summing their risks to obtain the total risk. An assessment of five indicates that the risk to the workers is typical of standard industrial projects. An assessment of three indicates that the risks to the workers are greater than for standard activities, but that the work activities do not need to be strictly controlled for life safety reasons. A worker risk assessment of one indicates that the work required is inherently dangerous and that much attention to worker safety is required before any tasks are performed. 


\subsubsection{Reduction of Risk}

The overall reduction of risles caused by the D\&D alternative is assessed in relation to the other D\&D alternatives. The reduction of risks to human health refers to the removal of radiological and hazardous materials from pathways that could impact human health. An assessment of one is used when the risks to the ORNL workers and the general public are not removed and when the migration of contaminants is not prevented. An assessment of two indicates that the risks are not removed or are only partially removed from the environment or that the migration of contaminants is partially mitigated. An assessment of three of the reduction of risks indicates that the contaminants are partially removed or that there is moderate prevention of the migration of contamination from the site to the general environment. An assessment of four indicates that most of the contamination is removed from the environment or that the migration of the contamination is prevented to the extent possible. An assessment of five is reported when all of the contamination is removed from the environment or when the migration is completely prevented. If this is not possible, the D\&D alternative representing the maximum removal of contamination is assessed as the maximum reduction of risk.

\subsubsection{Environmental Risk}

The environmental risles of each D\&D alternative are assessed for the period after the D\&D project is completed. Environmental risles refer to those radioactive and hazardous contaminants that could cause environmental harm if released from the structures into the general environment by transport into the air, surface water, groundwater, or solid materials. An assessment of five indicates that much of the contamination is removed from the environment or is prevented from migrating into the environment from the site. An assessment of three is used when some of the contamination is expected to be released into the environment from all sources. An assessment of one is used when little is done to prevent the movement of contamination from the site into the environment.

\subsubsection{Institutional Concerm}

The institutional concerns and requirements are evaluated in a semiquantitative manner according to the amount of institutional control required both during and after the D\&D project has been completed. This evaluation is split between the period before and during the D\&D project and after the conclusion of the project. For the period before and during D\&D, the assessments include only one and five. An assessment of five indicates that a normal amount of institutional control is required during the D\&D project. An assessment of one indicates that extra institutional oversight of the D\&D project is necessary. For the period after D\&D, the assessments are as follows: An assessment of five indicates that institutional controls can be removed from the site following the D\&D and remediation projects. An assessment of three indicates that institutional controls must be maintained at the site, such as S\&M of existing structures, even after the completion of the D\&D and remediation projects. An assessment of one requires that more extensive controls are required in order to continue to protect human health and the environment. The two assessments are then combined to produce a single one. If the during $D \& D$ assessment is five, then the overall rating is the after assessment plus one (i.e., a five before D\&D plus a three after D\&D results in an overall assessment of four). 


\subsubsection{Technical Fearibility}

Technical feasibility is assessed according to the applicability of currently available technology to perform the required tasks. A rating of one for technical feasibility is used for technologies that are poorly demonstrated or that require continued research or development before implementation for the D\&D alternative. A rating of three indicates that the technology is available for performing the D\&D tasks, but at a high cost, with a high probability of rework or with complex technological requirements. A rating of five for technical feasibility indicates that the tasks use currently available technologies. Additionally, the technical feasibility criterion includes the ability to perform the required tasks on the particular building being decommissioned. An example is the requirement to perform surface decontamination on a completely contaminated wall while leaving the wall intact. If, after removing all of the contamination, no wall is left standing, then, even though the technology is available to perform the decontamination (a rating of five), the task is rated a one to indicate that it cannot be accomplished as required.

\subsubsection{Program Compatibility}

Program compatibility is individually assessed for each D\&D alternative. A rating of one for compatibility indicates that one or more provisions of the D\&D alternative conflicts with the requirements of the D\&D program. A rating of three indicates that, although the provisions of the D\&D alternative do not conflict with the D\&D program, they are inappropriate to the goals of the D\&D program. An assessment of five for program compatibility indicates that the D\&D alternative is in complete agreement with the goals and requirements of the D\&D pre Tam at ORNL.

\subsubsection{Wate Management}

Waste management includes the generation of primary waste and secondary waste. Primary waste is the waste being generated by the actual dismantling or decontaminating processes and consists of the actual parts of the two buildings. Secondary waste is the waste generated, but not primary wastes, such as gloves and surveillance and survey materials. The two aspects of waste management, primary and secondary, are assessed separately as indicated below.

\subsubsection{Primary waste management}

Assessment of the primary waste is not considered as a separate criterion for the evaluation of the alternatives. The generation of primary waste and its quantity are integral parts of both the cost and technical feasibility criteria. The cost explicitly includes the cost for ultimate disposal of the volume of primary waste generated at a local waste disposal facility [Solid Waste Storage Area (SWSA) 6]. Technical feasibility includes the primary waste in determining the effective techniques for dismantling and decontaminating the buildings.

\subsubsection{Secondary wate management}

Assessment of the secondary waste generated is considered separately. A rating of five represents a D\&D alternative that only produces the quantities associated with personnel protection, surveillance, and required surveys. A rating of three represents a D\&D alternative that produces small or moderate volumes of secondary waste from the decontamination 
processes in addition to the required quantities for personnel protection, surveillance, and surveys. A rating of one indicates that the tasks required to perform the D\&D alternative generate large quantities of secondary wastes, such as contaminated wash waters.

\section{BUILDNG 3506}

The semiquantitative assessment of the D\&D alternatives for Building 3506 is provided in Table 3.

\section{Continued S\&M}

The continued S\&M alternative, while low-cost in a single year, will increase in total cost as the number of years of S\&M increases. In addition, at the end of the continued S\&M period, the cost of one of the other D\&D alternatives must be added to the existing S\&M cost. Therefore, even though the annual cost is low for this alternative, the overall project cost (life cycle) will be high. In addition, over the course of years of maintenance, the above-grade portions of the structure will be essentially replaced, converting the continued S\&M alternative into a hybrid of continued S\&M and decontamination.

\section{Decontamination}

The decontamination alternative is desirable, except that the structure is still standing, presumably free released in the middle of an area of contaminated soil that has not yet been remediated by the soils remediation project. Therefore, the compatibility with the ER program is not high, because the soil below Building 3506 may require remediation, and the presence of above-grade structures restricts access to the immediate area.

\section{Entombment}

The entombment alternative requires that the 3506 building be sealed into a concrete monolith. Because this building has previously undergone decontamination activities, it has little remaining radioactivity or hazardous contaminants. Therefore, this alternative is not realistic, because there is little radioactivity to contain by entombment. In addition, the program compatibility is not high, because the structure remains, and the soil below the structure probably requires remediation.

\subsection{Partial Diamantlement}

The partial dismantlement alternative meets almost all of the criteria for performance, except that the concrete structure is still in the ground. Depending on the selected scenario for remediation of WAG 1 soils, the below-grade structures may be closed in place.

\section{Complete Dismantiement}

The complete dismantlement alternative meets all of the criteria for the D\&D project. In addition, it allows free access to the contaminated soils beneath Building 3506 for the soils remediation project. 
Table 3. Semiquantitative cvaluation of D\&D alternatives for Building 3506

\begin{tabular}{|c|c|c|c|c|c|}
\hline Citerion & $\begin{array}{l}\text { Continued } \\
\text { SedM }\end{array}$ & Decontanination & Bntombenent & $\begin{array}{c}\text { Partiel } \\
\text { Dimantlemext }\end{array}$ & $\begin{array}{l}\text { Complete } \\
\text { Dirmantlement }\end{array}$ \\
\hline $\cos t$ & 5 & 3 & 1 & 4 & 2 \\
\hline Worter Rint & 5 & 5 & 5 & 5 & 4 \\
\hline Reduction of Risk & 1 & 5 & 3 & 5 & 5 \\
\hline Euvironmental & 1 & 5 & 5 & 5 & 5 \\
\hline Institutional & 4 & 4 & 4 & 5 & 5 \\
\hline Feasibility & 5 & 5 & 3 & 5 & 5 \\
\hline Compatibility & 1 & 3 & 3 & 4 & 5 \\
\hline Secondary Waste & 5 & 5 & 5 & 5 & 5 \\
\hline SUM & 27 & 35 & 29 & 38 & 36 \\
\hline
\end{tabular}

\subsection{BUIIDNG 3515}

The semiquantitative assessment of the D\&D alternatives for Building 3515 is provided Table 4.

\subsubsection{Continued SeaM}

The continued S\&M alternative, while low-cost in a single year, will increase in total cost as the number of years of S\&M increases. Additionally, at the end of the continued S\&M period, the cost of one of the other D\&D alternatives must be added to the existing S\&M cost. Therefore, even though the annual cost is low for this alternative, the overall project cost (life cysle) will be high.

\subsubsection{Decontamination}

The decontamination alternative for Building $\mathbf{3 5 1 5}$ is not technically feasible, because surface decontamination of the interior surfaces of the building would probably result in the de facto demolition of the structure. Therefore, trying to maintain the structural integrity of the building while decontaminating it will require enormous refitting and work to accomplish the task. This alternative also leaves the building intact, so that remediation of the soil below the building would be a difficult task. 
Table 4. Semiquantitative cvaluation of D\&D alternatives for Building 3515

\begin{tabular}{|c|c|c|c|c|c|}
\hline Citerion & $\begin{array}{l}\text { Continued } \\
\text { SelM }\end{array}$ & Decontrmination & Entombenent & $\begin{array}{c}\text { Partiol } \\
\text { Dimmantlement }\end{array}$ & $\begin{array}{c}\text { Complete } \\
\text { Dimmanilement }\end{array}$ \\
\hline Cost & 5 & 2 & 1 & 4 & 3 \\
\hline Worter Rink & 3 & 3 & 1 & 3 & 3 \\
\hline Reduction of Riet & 1 & 5 & 3 & 4 & 5 \\
\hline Environmeatal & 1 & 5 & 3 & 5 & 5 \\
\hline Inctitutional & 1 & 2 & 2 & 3 & 4 \\
\hline Fensibility & 5 & 1 & 3 & 5 & 5 \\
\hline Compatibility & 1 & 3 & 3 & 4 & 5 \\
\hline Secondary Wate & 4 & 3 & 3 & 3 & 3 \\
\hline SUM & 21 & 24 & 19 & 31 & 33 \\
\hline
\end{tabular}

\section{3 .3 Entombment}

The entombment alternative is acceptable, although, like the decontamination alternative, remediation of the soil beneath the entombed building would be difficult. However, there is very little confidence that the below-grade entombment process would completely contain the radioactive and hazardous contaminants. The acceptability of this alternative is further reduced, given the worker risk in performing this entombment. The subsequent soil remediation effort would be especially difficult given the effort required to entomb the concrete slab on-grade and ensure that migration of radioactive or hazardous materials would not occur.

\subsection{Partial Dismantlement}

The partial dismantlement alternative meets almost all of the criteria for performance, except that, because the concrete pad and sampling station are still in the ground, the soils remediation project must include those costs for their remediation.

\subsubsection{Complete Dismantlement}

The complete dismantlement alternative meets all of the criteria for the D\&D project. In addition, it allows free access to the contaminated soils beneath Building 3515 for the soils remediation project. 


\section{UNCERTAINTIES AND ASSUMPTIONS}

This section describes the uncertainties and assumptions that are inherent in the semiquantitative evaluation of the D\&D alternatives for the two buildings. The first two sections list the uncertainties and assumptions that are common to both buildings. The next two sections give the Building 3506 specific uncertainties and assumptions, while the last two sections describe the Building 3515 specific uncertainties and assumptions.

\section{G.1 GENERAL UNCERTAINTIES}

The identified uncertainties that are common to both buildings are listed below.

- The schedule for the D\&D of the two buildings in relation to the remediation of the soil in the GAAT OU is an uncertainty. If the remediation of the soil around the buildings is scheduled so that the completion of the D\&D project feeds immediately into the remediation of the soil, the task in Alternatives 4 and 5 for both buildings of backfilling and grass seeding is no longer necessary. If this is the case, then the cost for these alternatives would be reduced. Conversely, if the remediation of the soil is scheduled to be completed before the start of the D\&D projects, then the remaining soil remediation must be scheduled after the completion of the D\&D projects, increasing the cost of the remediation. The maximum cost occurs if the D\&D project is completed well before the start of the soil remediation, so that the D\&D project pays for the backfilling, grading, and seeding, and the remediation project pays for the removal of the clean overburden before starting the remediation.

- For the entombment alternative, uncertainty exists whether any operation such as grout injection would completely seal the below-grade structures. In addition, verifying that the below-grade structures are completely sealed may not be feasible. In any event, sealing the below-grade structures while leaving the contaminated soil alone would cause further problems with the soil remediation task, especially for volumes below the center of the building.

- In the decontamination alternative, uncertainty exists whether the decontaminated portions of the building will remain structurally intact. Additional work may be required to provide for permanent repair or support of the building structure. Furthermore, the basic structural integrity of the building is uncertain.

\section{GENERAL ASSUMPTIONS}

The identified assumptions that are common to both buildings are listed below.

- All wastes will be no greater than LLW (i.e., no high-level waste nor transuranic materials). However, it is expected that the radiation field around the packages from Building 3515 will be high enough to require remote handling.

- All sides of the buildings can be accessed for D\&D purposes. 
- Underground utilities will be sealed at the outside edge of the foundation (or trench, if any) for both buildings, and the remediation project will be responsible for draining and remediating the remainder of the system, back to the nearest system-wide connection point.

\section{BUIIDDNG 3506 UNCERTANTITES}

Specific uncertainties for estimating the cost of the preferred alternative for D\&D of Building 3506 are listed below.

- Contamination of the building from materials contained within the connecting underground piping is unknown.

- The amount of contained rainwater is unknown.

\subsection{BUILDING 3506 ASSUMPTIONS}

Specific assumptions for estimating the cost of the preferred alternative for D\&D of Building 3506 are listed below.

- The interior is basically clean because of previous decontamination operations. Specifically, the areas requiring decontamination for any alternative do not exceed $10 \%$ for the wood-framed portion, $20 \%$ of the above-grade portions of the cells, and $50 \%$ of the below-grade portions of the cells.

- All decontamination or demolition work tasks can be done with minimal contamination control requirements. Specifically, activities that would reduce worker productivity are unnecessary.

- Any rainwater will be treated as process waste.

- For the decontamination alternative, the building will not receive upgraded utilities.

- For the complete dismantlement alternative, the concrete pad and cell pits below-grade will be removed by segmenting and removing the walls and the bottom separately. Alternatively, the concrete could be rubbled and removed.

\section{BUILDNG 3515 UNCERTANNTIES}

Specific uncertainties for estimating the cost for D\&D of Building 3515 using the preferred alternative are listed below.

- Contamination of the building from materials contained within the connecting underground piping is unknown.

- The magnitude of the radiation field within and under the building is unknown. 
- The magnitude of contamination on the equipment is unknown. This contamination results in elevated radiation dose rates around the equipment.

- The hazard presented by the presence of chemicals remaining in the process equipment is unknown.

- The process equipment, as illustrated by the available photographs, is still installed as shown. No addition or removal of equipment is known to have occurred.

- The structural integrity of the building is unknown.

- The interior configuration, exterior outline, and building height of the sealed building is unknown.

\section{BUILDNG 3515 ASSUMPTIONS}

Specific assumptions for estimating the cost for D\&D of Building 3515 using the preferred alternative are listed below.

- Even though the magnitude of the radiation field within the building is unknown, human access will presumably be prohibited during a major portion of the project. Consequently, most D\&D work will be done remotely.

- The roof will structurally support the required initial characterization and D\&D tasks (i.e., personnel and hand tools but no large equipment).

- The steam and air lines on the east side of the building can be rerouted for the duration of the D\&D project.

- No chemical hazards are present in the building nor in the process equipment. Specifically, any chemicals remaining present no special fire or explosion hazards as a result of being sealed for over $\mathbf{3 0}$ yr.

- For the decontamination alternative, the building will not receive any utilities.

- For the complete dismantlement alternative, the concrete pad and sampling station will be removed by segmenting and removing the walls and the bottom separately. Alternatively, the concrete could be rubbled and removed.

- A high efficency particulate air-filtered exhaust system will be installed as the first item in the D\&D. There will be a constant exhaust of $\sim 2,000 \mathrm{cfm}$ throughout the project.

- The penetration into the building requires shielding to protect D\&D workers and the general ORNL population from radiation streaming or scattering from the interior of the building. A steel structure of 3-in. thickness is assumed to be required for the shielding of the direct radiation. A steel roof of 1-in. thickness is assumed sufficient to shield the scattered radiation. 
- Specially designed boxes will provide sufficient shielding to permit handling and movement without entirely stopping work activities.

- For purposes of the cost estimate, the contamination and resulting radiation fields are considered to be very high (>1 R/hr at $1 \mathrm{ft})$.

- The lead bricks would be encapsulated and transported to a commercial mixed waste disposal facility for disposal.

- Based on the available information, a building layout was developed and assumed for cost estimating purposes only.

- D\&D activities will be coordinated with adjacent operations, including normal workday operations, to limit personnel exposure to radiation.

- The D\&D operations can be done using existing remote handling technology.

- Temporary shielding during off-working hours to protect casually exposed personnel will use materials existing for the project. 


\section{RECOMMENDED ALTERNATIVES}

This section riescribes the recommended alternatives for the D\&D of Buildings 3506 and 3515. Section 7.1 discusses Building 3506, while Sect. 7.2 discusses Building 3515.

\subsection{BUIILDNG 3506}

The recommended alternative for the D\&D of Building 3506 is partial dismantlement. This alternative has a total score of $38 \mathrm{vs}$ complete dismantlement, with a score of 36 , and decontamination, with a score of 35. Reasons for the selection of this alternative are provided below.

The main reason for the selection of partial dismantlement is that the concrete foundation below-grade remains and would be handled by the soils remediation project for disposition. Because of the relative lack of known soil contamination under Building 3506, the soils remediation project may elect to leave the concrete structure in place, which would reduce ER costs. / wother reason to leave the foundation for the soils remediation project is that, if D\&D did the removal, the contaminated soils would have to be handled twice, once by D\&D in the excavation and again by the remediation project to perform final treatment and disposition. Thus, costs are doubled for the soil, if D\&D performs excavation.

The cost of the complete dismantlement alternative is judged to be greater than the partial dismantlement and decontamination alternatives because of the extensive excavation required to remove the below-grade structures. The worker risk is considered greater in the complete dismantlement, because the D\&D workers will be in contact with contaminated soils. This is a moot point for all the GAAT OU projects because, if the soil requires removal, the risk would be associated with one or another of the projects, and the lowered risk to D\&D is associated with a corresponding increase in worker risk in the soils remediation project. An offsetting criterion between partial and complete dismantlement is program compatibility. In complete dismantlement, the structures are removed sooner and represent an incremental increase in program compatibility for the complete dismantlement alternative.

The decontamination alternative scored almost as high as the complete dismantlement. The major disadvantages for this alternative are the requirement for continued S\&M of the released facility after the D\&D project and the compatibility with the D\&D program goal of removing completely the facilities being decommissioned. Also, there is no expected benefit in terms of the reuse of the decontaminated facility or of the equipment contained within. The relative lower cost of decontamination is an offsetting factor.

After the ongoing characterization of Building 3506 ends, some of the uncertainties listed in Sect. 6.3 will be resolved. In addition, some of the assumptions in Sect. 6.4 may be changed. Consequently, a reexamination of this evaluation and associated D\&D cost estimate is recommended to determine whether a revision to the cost estimate is warranted.

The semiquantitative analysis results for Building 3506, illustrated in Table 3, show that the complete dismantlement alternative scored second. Consequently, a cost estimate for the complete dismantlement alternative has been included in this document as well. 


\section{BUIIDNG 3515}

The recommended alternative for the D\&D of Building 3515 is complete dismantlement, with one caveat. This alternative has a total score of $33 \mathrm{vs}$ partial dismantlement, with a score of 31. Reasons for the selection of this alternative are provided below.

The main reason for the selection of complete dismantlement is that the soils below the foundation are known to be contaminated and will require removal or treatment during the soils remediation project. The partial dismantlement alternative requires scabbling of the top surface of the foundation. The soils remediation project would then have to remove and dispose of the concrete foundation in exactly the same manner as would have been done in the D\&D project. Therefore, the partial dismantlement D\&D project, which has the added cost of the scabbling, drives up the overall cost of the site remediation, including D\&D and soils remediation.

The caveat to the recommendation for complete dismantlement concerns the removal of the foundation. It is considered that the $D \& D$ project can remove the foundation without disturbing the underlying soil, to any great extent. If this is not the case and soils have to be disturbed by extensive excavation, the D\&D project's cost and worker risk would increase.

The cost of the complete dismantlement alternative is judged to be higher than the partial dismantlement alternative because of the disposal of the concrete in SWSA 6. In this evaluation, the scabbling cost is approximately equal to the cutting cost, resulting in no relative difference.

The worker risk is judged the same for both partial and complete dismantlement alternatives, because the worker risk from scabbling the top surface of the concrete is like the worker risk from cutting the concrete into appropriately sized pieces for packaging and disposal. In addition, the worker risk for the eoils remediation project, given partial dismantlement, would be increased by adding the risk of cutting the concrete foundation to the risk in the soils remediation project. Therefore, having the soils remediation project remove the concrete foundation results in increased worker risk for the remediation projects.

The institutional concerns for the complete dismantlement alternative are judged to be better than for the partial dismantlement alternative. This is because, for the period between the conclusion of the D\&D project and the start of the soils remediation project, the complete dismantlement alternative requires less institutional control than the partial dismantlement alternative. Another highly rated criterion for complete dismantlement is program compatibility. In complete dismantlement, the structures are removed sooner and represent an incremental increase in program compatibility for the complete dismantlement alternative.

No other alternative scored close to the partial and complete dismantlement alternatives. Therefore, no assessments between other alternatives are required.

The semiquantitative analysis results for Building 3515, as illustrated in Table 4, show that the partial dismantlement alternative scored second. Consequently, a cost estimate for the partial dismantlement alternative has been included in this document as well. 
After the conclusion of the ongoing characterization of Building 3515, some of the uncertainties listed in Sect. 6.5 will be resolved. In addition, some of the assumptions in Sect. 6.6 may be changed. Consequently, it is recommended bat this evaluation and associated D\&D cost estimate be reexamined to determine whether a revision to the cost estimate is warranted. 


\section{COST ESTIMATE_RECOMMENDED ALTERNATIVE}

This section provides the basis for the cost estimate and the cost estimates for both buildings. Section 8.1 discusses the basis for the cost estimates, Sect. 8.2 provides the details of Building 3506's cost estimate and schedule, and Sect. 8.3 provides the details of Building 3515's cost estimate and schedule.

\subsection{BASTS FOR COST ESTMMATE}

The information contained in this section is intended to provide an understanding of the methodology used in developing the cost for this project.

\subsubsection{Enyincering Entimnte}

The engineering cost estimate consists of Titles I, II, and III engineering (Table 5). Titles I and II engineering include all of the design activities required for the D\&D work plan. Title III engineering includes those engineering-related activities necessary to ensure that construction conforms to Titles I and II design drawings and specifications. Titles I, II and III engineering costs are estimated as a percentage of construction or are based on an appropriate level of effort necessary for this particular project. Computer costs, reproduction costs, travel costs, and material costs were also included in the estimates. Project management has been factored into the estimate to include Titles I and II reports; schedule development and maintenance; cost reporting; progress reporting; contract administration; staffing; project review; meetings; project direction; and guidance by the Project Manager, Project Engineer, Program Director, and Task Engineer/Coordinator.

Table 5. Engincering cost eatimnte

\begin{tabular}{cccc}
\hline Building & A-E Title I \& II & A-E Tite III & MMES Title III \\
\hline 3506 & $300 \mathrm{hr}$. & 1/2 FTE for 1-1/2 mo & $11 / 2$ FTE for 1-1/2 mo \\
3515 & $15 \%$ of FPC & 1/2 FTE for 9 mo & $11 / 2$ FTE for 9 mo \\
\hline
\end{tabular}

\section{Construction Estimate}

\section{Material and labor pricing}

The construction estimate was based on bills of material (BMs) prepared by each participating design discipline. The BMs were summarized and reviewed for reasonableness of the work task by the lead estimating engineer. Each discipline was then estimated by estimators specialized in that discipline. The crafts that will perform the tasks were identified, and the appropriate wage rates were applied. Material and labor pricing was based on vendor quotes, recent similar job history, and nationally recognized publications such as $R$. Means Construction Cast Data and Richandson's Construction Estimating Standards. Special equipment costs were obtained either by vendor contact or data from similar projects. 


\section{Wage rates}

The wage rates for construction labor are those current as of January 1993 for the Oak Ridge area from the Automated Estimating System (AES) Standard Value File ORER193.VAL. These rates are effective for an hour of productive work and are given in Table 6.

Fixed-price construction labor rates are based on an average crew with neceasary craftsmen, foremen, general foremen, etc. All fringe benefits, payroll taxes, and workman's compensation insurance are included.

Table 6. Standard value File, January 1993

\begin{tabular}{ccc}
\hline Code & Crat & Fred Price \\
\hline AW & Asbestos Worker & 25.45 \\
BM & Boiler Maker & 26.35 \\
M & Brickmason & 22.60 \\
C & Carpenter & 22.15 \\
F & Cement Finisher & 19.45 \\
E & Electrician & 22.95 \\
IW & Ironworker & 23.65 \\
L & Laborer & 15.45 \\
MW & Millwright & 22.55 \\
OP & Operating Engineer & 22.30 \\
P & Painter & 21.75 \\
PF & Pipefitter & 22.90 \\
R & Roofer & 17.75 \\
SM & Sheetmetal Worker & 23.80 \\
SF & Sprinkler Fitter & 25.30 \\
TD & Truck Driver & 16.80
\end{tabular}

\subsection{Additionsl coet consideration}

The base estimating units used in this estimate generally reflect a normal standard for construction costs. Many special work situations and job conditions can cause additional material consumption and/or a greater number of work hours to be used. During the estimating process, the estimating engineer included costs as appropriate depending on the anticipated job conditions for the following items: mobilization and demobilization; supporting items, breakage, and waste; temporary facilities; temporary services; cleanup; scaffolding; 
industrial hygiene; construction safety meetings; safety inspections; and allowances for Occupational Safety and Health Administration (OSHA) and United States Environmental Protection Agency (EPA) compliance.

\section{Indinect Markups}

The indirect markups used in this estimate have been applied according to the guidelines provided in the Oak Ridge Field Office Estimating and Cost Control Manual. Those appear in Table 7.

Table 7. Indirect martaps

\begin{tabular}{lcc}
\hline \multicolumn{1}{c}{ Category } & $\begin{array}{c}\text { General } \\
\text { Contractor }\end{array}$ & Subcontractor \\
\hline $\begin{array}{l}\text { Overhead (applied to labor and } \\
\text { materials) }\end{array}$ & $10 \%$ & $10 \%$ \\
Profit (applied to labor and materials) & $8 \%$ & $8 \%$ \\
Bond (applied to labor and materials) & $1 \%$ & $1 \%$ \\
General contractor's markup & & $5 \%$ \\
Compounded total & $20 \%$ & $26 \%$ \\
Sales tax (applied to materials) & $8.25 \%$ & $8.25 \%$ \\
\hline
\end{tabular}

Firod-price construction. For fixed-price general contractors' work, these markups compound and appear in the extimate as totals: indirect $20 \%$ and tax $8.25 \%$. For subcontractors' work, the markups appear as totals: indirect $26 \%$ and tax $8.25 \%$.

MK-Ferguson of Oak Ridge (MK-F), under prime contract to the U.S. Department of Energy (DOE), will award, administer, and manage all construction contracts required for this project. The indirect cost of this service is $12 \%$ of the fired-price construction value plus $\$ 51.70$ per work hour a computed from the MK-F administrative table and other miscellaneous equipment costs.

MMES site overhead Martin Marietta Energy Systems, Inc. (MMES), site overhead is included on DOE contractors and MMES labor, purchased materials, and contractors.

MMIES Inbor. MMES site overhead is applied to all MMES labor. This overhead recovers costs associated with administration, facilities maintenance, plant services, corporate and central services, and general expenwes. The rates are $46.01 \%$ for ORNL personnel and 25.37\% for ORNL Central personnel.

MMIES purchmed mnterink. MMIES site overhead is applied to all purchased materials with the exception of single item purchases of more than $\$ 20,000$. This overhead recovers costs associated with administration, facilities maintenance, plant services, corporate and central services, and general expenses. This overhead rate is $46.01 \%$. 
MMES and DOE contractors. An off-site subcontractor overhead is applied to the total cost uf all DOE prime contracts and subcontracts to MK-F or MOMES, except for the A-E Title III Engineer, technical support, contractor, and environmental assessment subcontractor. This overhead is an apportionment of the costs of plant services, purchasing, facilities maintenance, administration, etc. The off-site subcontract rate is $8.7 \%$.

Project management-Energy Systeme Project management services consist of A-E and construction support. This work spans all facets of the project and its administration and is included as construction cost. Project management includes those activities necessary to support the project such as A-E design coordination and review, cost estimate reviews, field support of construction, project reviews and reporting, project coordination and planning, and other direct costs such as travel, reproduction, inspection materials, etc. Costs (Table 8) were estimated as a percentage of FPC or were based on an appropriate level of effect required.

Table \&. Project management costs

\begin{tabular}{ccccc}
\hline & $\begin{array}{c}\text { MMES } \\
\text { Project } \\
\text { Services }\end{array}$ & $\begin{array}{c}\text { MMIES } \\
\text { Divisional } \\
\text { Support }\end{array}$ & $\begin{array}{c}\text { MMIES Project } \\
\text { Management }\end{array}$ & $\begin{array}{c}\text { MMIES A-E } \\
\text { Support }\end{array}$ \\
\hline 3506 & $8 \%$ of FPC & $5 \%$ of FPC & $1 / 2$ FTE for 3 mo & $6 \%$ of FPC \\
3515 & $8 \%$ of FPC & $5 \%$ of FPC & 1/2 FTE for 12 mo & $6 \%$ of FPC \\
\hline
\end{tabular}

\subsection{Ercalation}

The estimate has been escalated using the DOE Oak Ridge Field Office (DOE-OR) approved annual rates issued by MMIES in the January 1993 Standard Value File. The estimate is based on FY 1993 fourth quarter costs and then escalated over the period of activity, as determined by the project schedule.

The approved eacalation rates are $2.4 \%$ for FY 1993, 3.1\% for FY 1994, and 3.5\% for FY 1995, 3.7\% for FY 1996, and 3.8\%/yr thereafter.

\subsection{Extimate Assumption:}

\subsubsection{Typical asumption for bacis of extimate}

Labor (all shifts are $8 \mathrm{hr}$ each) productive work time calculations are as follows:

- Work performed in uncontaminated areas includes nonproductive time such as travel between portals and work stations and breaks.

- Level D work conditions require an additional $10 \%$ of work hours to be expended for nonproductive time.

- Level C work conditions require an additional 25\% of work hours to be expended for nonproductive time. 
- Level C and D personal protective equipment and clothing have been calculated at $\$ 21.00$ and \$3.61 per total work hour, respectively. This includss replacement and laundry costs.

\subsection{Geoveral axumption}

- MMES will furnish a portable boundary control station with monitoring equipment to be set up at each site. Cost is assumed to be $\$ 100,000$ and will be shared by each project.

- Personnel protective equipment (PPE) will be furnished by MMES.

- MK-F will provide industrial hygiene and health phyrics support to Fired Price Contractor.

- Traffic rerouting may be required during D\&D; however, its cost has not been included.

- Cost for on site disposal of $2^{-1}$ materials in B-25 or other boxes is assumed to be $\$ 85.00$ per $\mathbf{f t}^{3}$.

- Liquid waste will be drummed and transported to the Process Waste Treatment Facility for treatment/disposal. The cost is assumed to be $\$ 0.11$ per gal.

- After the structure has been removed, the area will be covered with a 60 mil high-density polyethylene (HDPE) liner, $2 \mathrm{ft}$ of soil, and grass cover.

\subsubsection{Building 3506 asumption-partinl dismantement}

- Building 3506 can be demolished uxing standard demolition techniques.

- All equipment and building materials will be cut up and placed in B-25 or B-12 boxea for dispoesl.

- Fifty percent of the remaining below-grade pit will be scabbled to a depth of $1 / 4$ in. to remove any contamination before being filled. This is necessary to be able to release the building for unrestricted we after the D\&D project is concluded. How much of the area may need to be decontrminated is unknown, but $50 \%$ is expected to be sufficient to estimate this item.

- The above-grade concrete structure will be demolished. Of this demolished concrete, 972 $\mathrm{ft}^{3}$ will be placed into the remaining below-grade pit. The remaining volume of rubble will be placed in B-25 boses for disposal.

- The disturbed area will be covered with an HDPE liner and soil cap.

- Level C protective equipment will be required for scabbling. All oíner demolition activities will require Level D protection.

\subsubsection{Buiding 3506 asumption-oxaplete diemmitement}

- Building 3506 can be demolished using standard demolition techniques. 
- All equipment, building materials, and structure will be demolished, cut up, and placed in B-25 or B-12 boxes for disposal.

- Soil excavated during removal of the below-grade structure will be replaced into the bottom of the excavated volume. The remaining excavated volume will be filled with clean borrow soil and the disturbed areas will be covered with a HDPE liner and soil cap.

- Demolition and excavation activities will require Level D protective equipment.

\subsection{Building 3515 saumption-complete diamantlement}

- Building 3515 cannot be demolished using standard demolition techniques. Remote operated eouipment will be required.

- A factor of 3.2 has been applied to standard labor unit rates to adjust for remote operation activities.

- Equipment located inside the building will be cut up with hydraulic shears and placed into specially sized boxes that have 2 in. of steel shielding.

- The lead bricls will be placed into $1.6 \mathrm{ft}^{3}$ bouces constructed of $1 / 2$ in. carbon steel. Each box will bold $1 \mathrm{ft}^{3}$ of bricks encapsulated in an epoxy grout. These containers will be shipped to an off-site disposal facility. Cost of this disposal is assumed to be $\$ 45$ per $\mathrm{ft}^{3}$.

- The remaining concrete structure and foundation will be cut up into blocks using diamond wire or circular-type saws. The concrete blocks will be placed into B-25 boxes for disposal.

- Remotely operated equipment will include manipulator hydraulic shears, cameras, and monitoring equipment mounted on articulating three-piece arms. A four-man crew will be required for operation.

- Shielding will be required for personnel protection during material removal operations. A custom designed shielding arrangement consisting of 3-in. of steel plates on the sides and 1-in. of steel plate on the roof will be constructed around the penetrations. After the material has been removed, boxed, and moved to a staging area for disposal, the shielding will be removed.

- The volume where the foundation was removed will be filled with clean borrow soil.

- The disturbed area will be covered with an HDPE liner and soil cap.

- Concrete cutting, work performed while in the shielded area, and closing of boxes will require Level C protective equipment. All other demolition activities will require Level D protective equipment. 


\subsubsection{Building 3515 asumptions-partial dismantlement}

- Building 3515 cannot be demolished using standard demolition techniques. Remotely operated equipment will be required.

- A factor of 3.2 has been applied to standard labor unit rates to adjust for remote operation activities.

- Equipment located inside the building will be cut up with hydraulic shears and placed into specially sized boxes that have 2 in. of steel shielding.

- The lead bricls will be placed into $1.6 \mathrm{ft}^{3}$ boxes constructed of $1 / 2$ in. carbon steel. Each box will hold $1 \mathrm{ft}^{3}$ of bricls encapsulated in an epoxy grout. These containers will be shipped to an off-site disposal facility. Cost of this disposal is assumed to be $\$ 45$ per $\mathrm{ft}^{3}$.

- The remaining concrete structure will be cut up into blocks using diamond wire or circular type saws. The concrete blocks will be placed into B-25 boxes for disposal.

- Remotely operated equipment will include manipulator hydraulic shears, cameras, and monitoring equipment mounted on articulating three-piece arms. A four-man crew will be required for operation.

- Shielding will be required for personnel protection during material removal operations. A custom-designed shielding arrangement consisting of 3-in. of steel plates on the sides and 1-in. of steel plate on the roof will be constructed around the penetrations. After the material has been removed, boxed, and moved to a staging area for disposal, the shielding will be removed.

- The foundation concrete slab will be scabbled to an average depth of 1 in. to remove any contamination and left in place.

- Level C protective equipment will be required for scabbling, concrete cutting, work performed while in the shielded area, and closing of boxes. All other demolition activities will require Level D protective equipment.

\subsection{Contingency in the extimate}

According to DOE Order 4700.1, contingency is defined as the sum of funds included within an estimate to cover materials, labor, conditions, and risk situations which are an intrinsic part of the presently intended scope of work but are not specifically allowed for elsewhere in the estimate because of uncertainty either as to their existence, nature, likelihood of occurrence, or magnitude of effect.

Contingency cost has been included in this project to cover costs that may result from incomplete design, unforeseen and unpredictable conditions, or uncertainties within the defined scope. A contingency analysis was conducted per headquarter guidance provided by the William Heffelfinger memorandum titled, "Cost Estimating Guide for Application of Contingency," dated June ,18, 1985. 
A midrange contingency of $30 \%$ for standard projects was chosen based on the referenced guidance. The midrange was adjusted by evaluation of the completeness of design and complexity of construction for each major Work Breakdown Structure (WBS) element.

Design completeness adjustment factors typically range from 0.7 to 1.5 , with 1.0 being the "average" completeness of design at the conceptual level. A greater than 1.0 adjustment factor would indicate a less than average "completeness of design."

Degree of complexity adjustment factor typically ranges from 0.7 to as high as 1.5 for extreme conditions. An adjustment factor of 1.0 would indicate a degree of complexity common at the BDR level with normal uncertainty as to procurement cost or installation complexity. Conversely, a 1.5 adjustment factor would indicate a one-of-a-kind design or, for example, the uncertainty associated with the disposal of a highly toxic or highly contaminated material or high levels of radiation in work areas.

Average contingency for Building 3506 is $30 \%$, while the average for Building 3515 is 33.5\%.

\section{BUILDING 3506}

The schedule for the partial decontamination alternative for the D\&D of Building 3506 takes into account the entire process and sequencing of tasks from the beginning of the work activities through decontamination, demolition, and backfilling of the building and through disposal of the waste materials at an existing on-site tumulus. The critical tasks identified determine the duration of the project. The schedule is illustrated in Fig. 1. A summary of the partial dismantlement alternative by the fourth-level project summary WBS (PSWBS) is shown in Fig. 2. All of the summary reports and the detail cost extimate for the partial dismantlement D\&D of Building 3506 are included in Appendix A A summary of the complete dismantlement alternative by the fourth-level PSWBS is shown in Fig. 3. All of the summary reports and the detail cost estimate for the complete dismantlement D\&D of Building 3506 are included in Appendix B. The schedule for complete dismantlement is the same as for partial dismantlement (Fig. 1). 


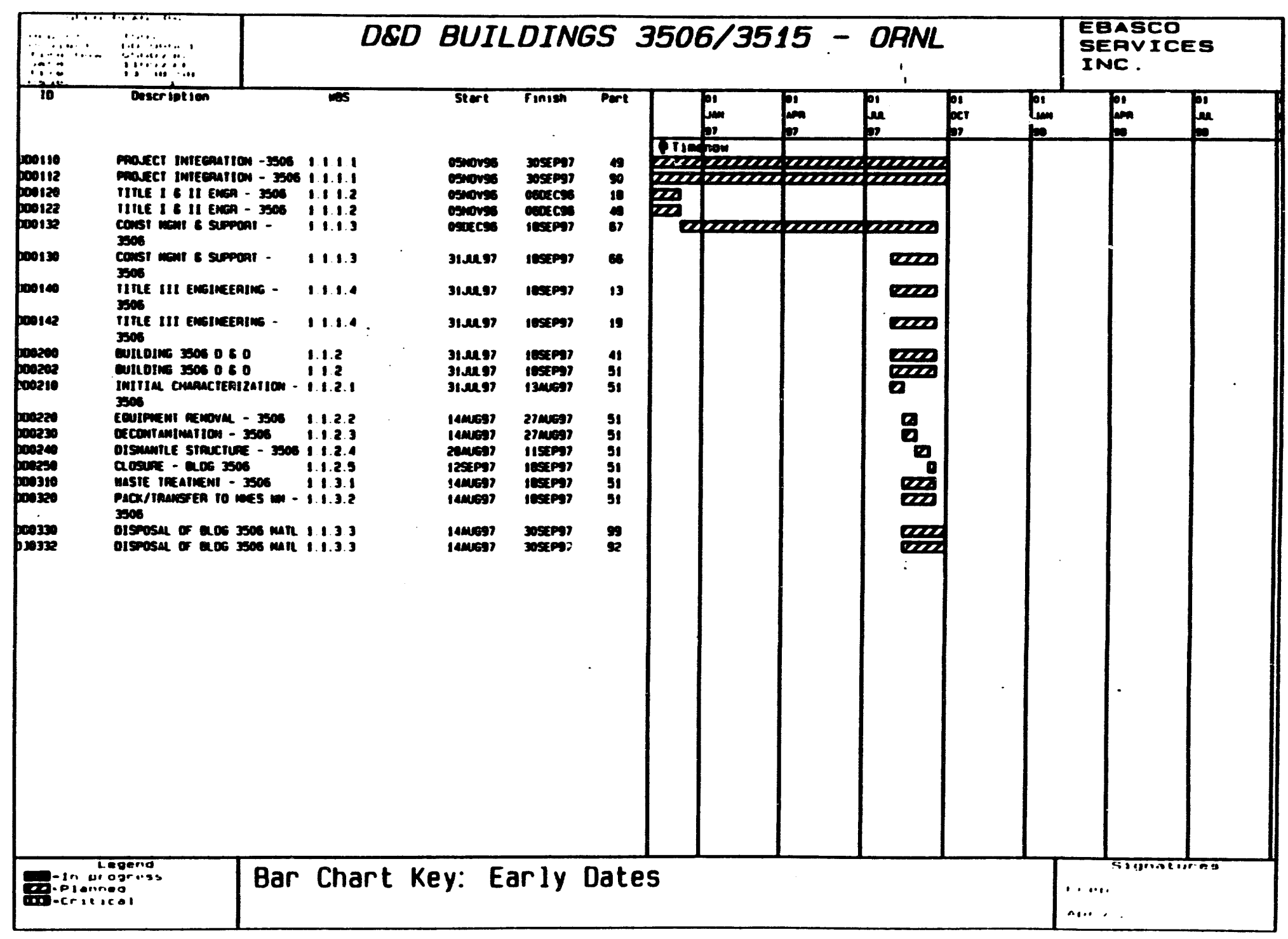

Fig 1. Schedule for D\&D of Building 3506. 
- L o alde 350\%, mantial

armant nerom

$81 \cdot \mathbf{s 1 0 0 0}$

$11 / 10$ res

Arrensed Oy: Us / Participent

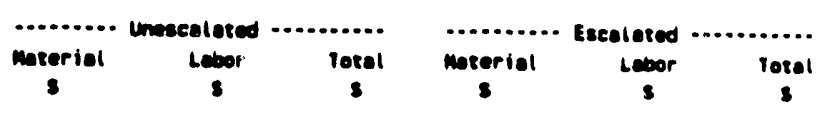

1.1.1.1 mouset inteenarion, 3506 69 mes movet reavicas

$\infty$ En Divistow

rotal moutet Inteearion, 3506

\begin{tabular}{llllll}
0 & 10 & 18 & 0 & 18 & 18 \\
1 & 21 & 22 & 1 & 21 & 22 \\
\hline 1 & 30 & 40 & 1 & 30 & 40
\end{tabular}

1.1.1.2 TITLE 1 a 11 Emolmientwe. 3506 18 A.E TITLE 1 \& 11 Emet.

40 mes $a-E$ expent

TOTAL TITLE I \& II EMGImEERING, 3506

\begin{tabular}{rrrrrr}
0 & 26 & 26 & 0 & 26 & 26 \\
0 & 0 & 8 & 0 & 0 & 8 \\
\hline 0 & 32 & 32 & 0 & 32 & 32
\end{tabular}

1.1.1.3 coust nemit a surecert, 3506

16 nK-F Ininects on Fp

67 ax-F Diafets on pp

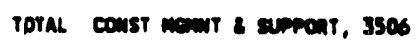

\begin{tabular}{rrrrrr}
16 & 0 & 16 & 15 & 0 & 15 \\
0 & 32 & 32 & 0 & 32 & 32 \\
\hline 16 & 32 & 46 & 15 & 32 & 47
\end{tabular}

3.1.1.4 TITLE III EmeImetaimg, 3506

13 mes ritue III ewer.

19 A-E TITLE III Ewer.

TOTAL TITLE III EMGIMERRIMG, 3506

\begin{tabular}{rrrrrr}
2 & 27 & 29 & 2 & 28 & 30 \\
0 & 7 & 7 & 0 & 7 & 7 \\
\hline 2 & 36 & 36 & 2 & 35 & 37
\end{tabular}

1.1.2 WILDIMG 3506 D \& O, mantIaL

61 mes PIeto mintemance

51 Fixed mice consteuction

TOIAL EILOINE 3506 D \& D, PAMTIAL

\begin{tabular}{rrrrrrr}
112 & 1 & 113 & 115 & 1 & 116 \\
33 & 36 & 60 & 34 & 37 & 71 \\
\hline 145 & 37 & 182 & 169 & 38 & 187
\end{tabular}

1.1.2.1 InITial cumactenizariom, 3306 51 pixed mice constaucrion

rotal ImIrial cmanactenizarton, 3506

\begin{tabular}{llllll}
2 & $\cdot 7$ & 9 & 2 & 7 & 0 \\
\hline 2 & 7 & 9 & 2 & 7
\end{tabular}

Fic 2 Fourth-level project summary by WBS for partial dismantlement of Building 3506. 


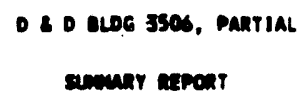

$81 \cdot 81000$

$11 / 10 / 93$

Arreneed ov: was / participent

1.1.2.2 Eeutmint removal, 3506

51 pixid mice consteuction

Total Eeulnuim aEmoval. 3506

1.1.2.3 ozcomtanimarion, 3506 51 pixed mice constuction

Total ofcomtamimation, ssos

1.1.2.6 D1 mantle stauctuats, 3506 51 fixud mice constaction

Total ol EanitLe stmuctune. 3506

1.1.2.5 Closine, 3506

51 FIXed mice comstauction

Total Clowne, 350 S

1:1.3.1 Tagarment, 3506

51. PIxed mice constmuction

Total Tacatmint, 3ses

1.1.3.2 Pacx/taumse to mess $\mathrm{m}, 3306$ 51 pixed mice consteuction

rotal pack/transf to mess in, 3506

1.1.3.3 DIencesal of DLDE 3506 mat'l 92 maste namaetinint

9 secial

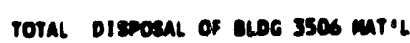

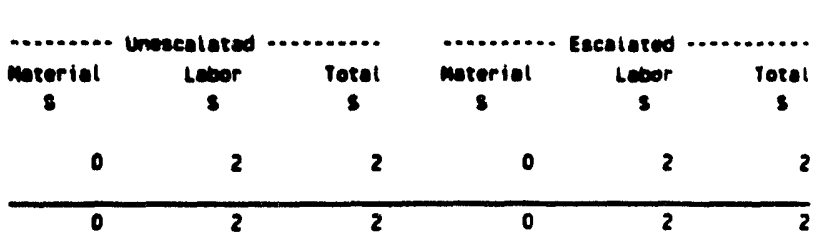

\begin{tabular}{llllll}
1 & 2 & 3 & 1 & 2 & 3 \\
\hline 1 & 2 & 3 & 1 & 2 & 3
\end{tabular}

\begin{tabular}{llllll}
5 & 11 & 16 & 5 & 11 & 16 \\
\hline 5 & 11 & 16 & 5 & 11 & 16
\end{tabular}

\begin{tabular}{llllll}
3 & 1 & 4 & 3 & 1 & 6 \\
\hline 3 & 1 & 4 & 3 & 1 & 6
\end{tabular}

\begin{tabular}{llllll}
5 & 0 & 5 & 5 & 0 & 5 \\
\hline 5 & 0 & 5 & 5 & 0
\end{tabular}

\begin{tabular}{llllll}
1 & 1 & 2 & 1 & 1 & 2 \\
\hline 1 & 1 & 2 & 1 & 1 & 2
\end{tabular}

\begin{tabular}{rrrrrr}
0 & 0 & 0 & 0 & 0 & 0 \\
326 & 0 & 326 & 335 & 0 & 339 \\
\hline 326 & 0 & 326 & 335 & 0 & 335
\end{tabular}

Fiz 2 (continued) 
o 0 clog sses, matial

exemer nevor

$81=81000$

11/10/es

Arranesed oy: wes / participant

$$
\text { w - total }
$$

comrinerner

eamo rotal

\begin{tabular}{|c|c|c|c|c|c|}
\hline moterial & $\begin{array}{c}\text { Uneacalased } \\
\text { tebor } \\
8\end{array}$ & Total & noterial & $\begin{array}{l}\text { lated } \\
\text { tebor } \\
8\end{array}$ & losel \\
\hline 505 & 190 & 703 & 519 & 200 & 719 \\
\hline 151 & 50 & 210 & 156 & 61 & 217 \\
\hline 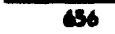 & 237 & 913 & 673 & 261 & 6 \\
\hline
\end{tabular}

Fie 2 (continued) 


\section{- 8 ones 3906}

\section{armaner ateont}

81 - 81000

$11 / 10 / 93$

Arreneed or: ws / Particieant

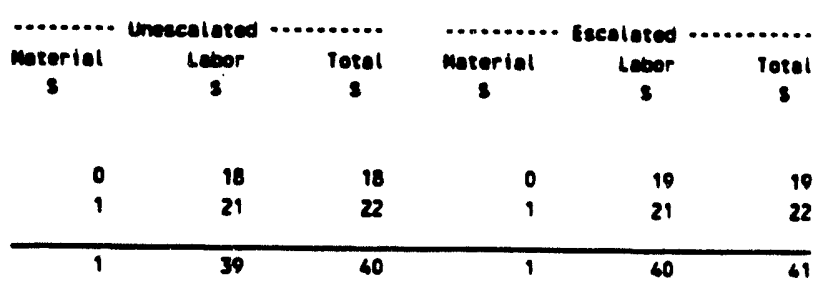

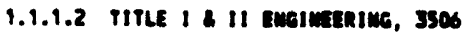

18 A-E TITLE 1 \& II EMER.

40 mes A-E surwont

TOTAL TITLE 1 \& 11 engingersing, 3506

\begin{tabular}{rrrrrr}
0 & 26 & 26 & 0 & 26 & 26 \\
0 & 0 & 8 & 0 & 8 & 8 \\
\hline 0 & 32 & 32 & 0 & 32 & 32
\end{tabular}

1.1.1.3 const mani 2 anecert, 3506

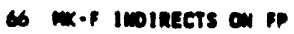

67 in-p Dinects on

total const nemit a grent, 3506

\begin{tabular}{rrrrrr}
15 & 0 & 15 & 15 & 0 & 15 \\
0 & 32 & 32 & 0 & 32 & 32 \\
\hline 15 & 32 & 67 & 15 & 32 & 67
\end{tabular}

1.1.1.4 TITLE III EngImetRing, 3506

13 mes ritle III emen.

19 A-E TITLE III Euen.

TOTAL TITLE III EMGImEering, 3SOS

\begin{tabular}{rrrrrr}
2 & 27 & 29 & 2 & 28 & 30 \\
0 & 7 & 7 & 0 & 7 & 7 \\
\hline 2 & 34 & 36 & 2 & 35 & 37
\end{tabular}

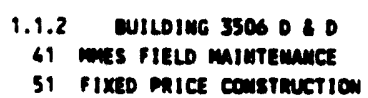

TOTAL EulLIMG 3505 o 0

\begin{tabular}{rrrrrr}
130 & 1 & 131 & 136 & 1 & 135 \\
33 & 36 & 49 & 34 & 37 & 71 \\
\hline 163 & 37 & 200 & 160 & 30 & 206
\end{tabular}

1.1.2.1 Intrial cmanactenszation, 3506 51 Fixed mite consteuction

TOTAL IMITIAL CManactenization, 3sos

\begin{tabular}{llllll}
2 & 7 & 9 & 2 & 7 & 0 \\
\hline 2 & 7 & 9 & 2 & 7
\end{tabular}

Fif. 3. Fourth-level project summary by WBS for complete dismantlement of Building 3506. 
D 20 cuso 3805

ement arrost

$81 \cdot 81000$

$11 / 10 / 43$

Arrenead or: uss / Partielenent

1.1.2.2 Eevinum nemoval, ssos 51 fixed mile comstaction

rotal ceutment newoval, ssas

1.1.2.3 Decowtmimation, s806

51 pixed mice constauction

total Decowtamimation, 3ses

1.1.2.4 otsmante stauctune, 3506 31 pixto mice constaction

rotal Dismante stactuat, 3906

1.1.2.5 Cloune, 3506

51 Fixio mice constmuction

TorAl cloant, 350

1.1.3.1 Tecarmint, 3sos

51 PIxtd mice consthuction

rotal takatment, 3506

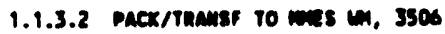
51 PIxed mice constuletion

total pack/taumsf ro mess $\mathrm{m}, 3306$

1.1.3.3 oteroosal of mos 3506 mat 'L 92 uste munarentur

6 encias

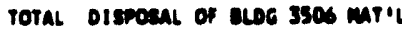

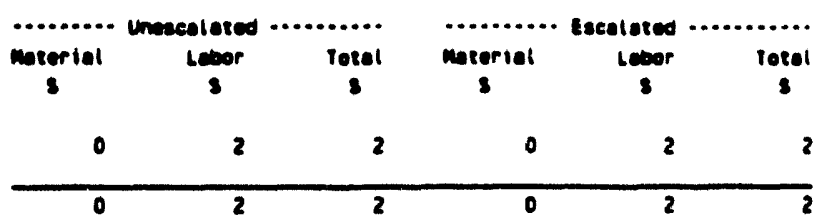

\begin{tabular}{cccccc}
0 & 0 & 0 & 0 & 0 & 0 \\
\hline 0 & 0 & 0 & 0 & 0
\end{tabular}

\begin{tabular}{lllllll}
9 & 15 & 26 & 0 & 16 & 25 \\
\hline 9 & 15 & 26 & 9 & 16 & 25
\end{tabular}

\begin{tabular}{llllll}
3 & 1 & 4 & 3 & 1 & 6 \\
\hline 3 & 1 & 4 & 3 & 1 & 4
\end{tabular}

\begin{tabular}{cccccc}
0 & 0 & 0 & 0 & 0 & 0 \\
\hline 0 & 0 & 0 & 0 & 0 & 0
\end{tabular}

\begin{tabular}{llllll}
2 & 1 & 3 & 2 & 2 & 4 \\
\hline 2 & 1 & 3 & 2 & 2 & 4
\end{tabular}

\begin{tabular}{rrrrrr}
0 & 0 & 0 & 0 & 0 & 0 \\
639 & 0 & 659 & 657 & 0 & 657 \\
\hline 69 & 0 & 650 & 657 & 0 & 657
\end{tabular}

Fig. 3 (continued) 


\section{0 ung 350s

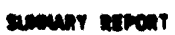

$$
81 \cdot 81000
$$ \\ $11 / 10 / \mathrm{s}$}

\section{Arreneed or: wes / Participent}

av - rotal centrimetuct

eam rotal

\begin{tabular}{|c|c|c|c|c|c|}
\hline nateriel & $\begin{array}{l}\text { ealated } \\
\text { Lear } \\
8\end{array}$ & retel & Woterial & tered & $\begin{array}{c}\text { Iotol } \\
5\end{array}$ \\
\hline $\begin{array}{l}3 \\
21\end{array}$ & $\begin{array}{r}200 \\
10\end{array}$ & $\begin{array}{r}1036 \\
311\end{array}$ & $\begin{array}{l}259 \\
z 80\end{array}$ & $\begin{array}{r}205 \\
2\end{array}$ & $\begin{array}{r}1024 \\
320\end{array}$ \\
\hline
\end{tabular}

Fiz. 3 (continued) 


\subsection{BUILDNG 3515}

The schedule for the complete decontamination alternative for the D\&D of Building 3515 takes into account the entire process and sequencing of tasks from the beginning of the work activities, through decontamination, demolition, and backfilling the building, through disposal of the waste materials at an existing on-site tumulus. The critical tasks identified determine the duration of the project. The schedule is illustrated in Fig. 4. A summary of the complete dismantlement alternative by the fourth level PSWBS is shown in Fig. 5. All of the summary reports and the detail cost estimate for the complete dismantlement D\&D of Building 3515 are included in Appendix C. A summary of the partial dismantlement alternative by the fourth-level PSWBS is shown in Fig. 6. All of the summary reports and the detail cost estimate for the partial dismantlenent D\&D of Building 3515 are included in Appendix D. The schedule for partial dismantlement is the same as for partial dismantlement (Fig. 4). 


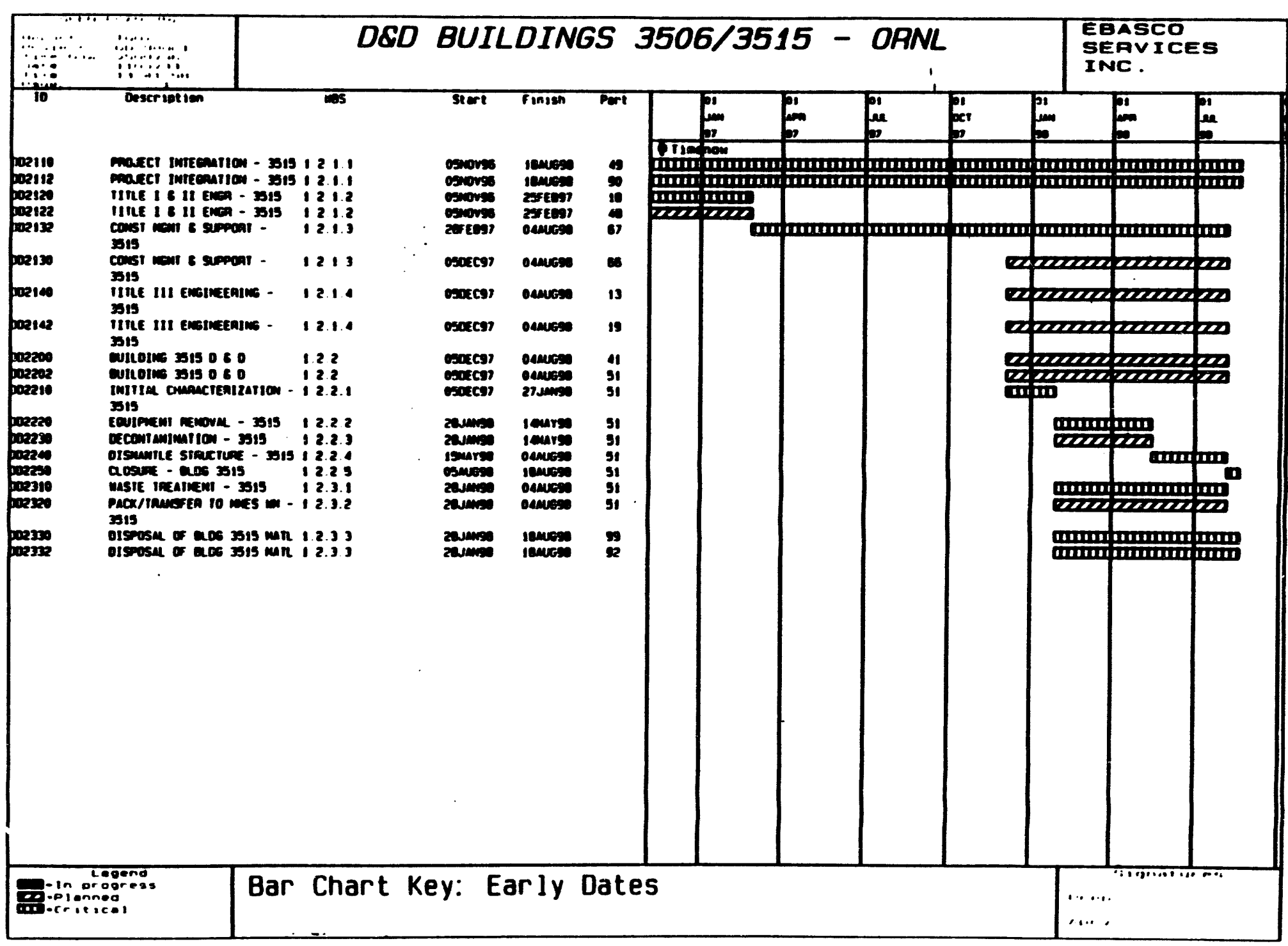

Fie 4. Schodule for DED of Building 3515. 


\section{5}

ammant ateont

$81=81000$

$11 / 10 / 9 s$

Arraneed Dy: ws / Particigent

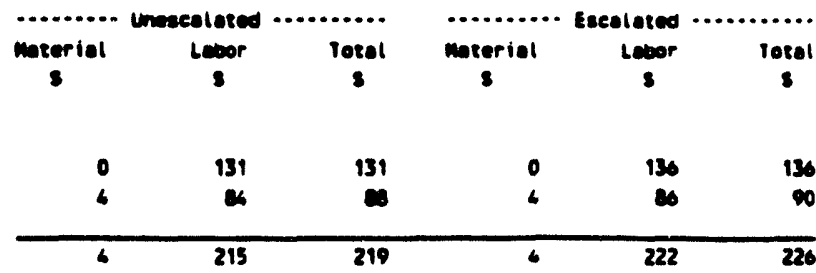

1.2.1.1 mostet Imtecarion, 3515

40 wes movect semviats

co en oivisio

Total movet IutEearion, 3sis

\begin{tabular}{rrrrrr}
0 & 121 & 121 & 0 & 122 & 122 \\
0 & 61 & 61 & 0 & 61 & 61 \\
\hline 0 & 182 & 182 & 0 & 183 & 183
\end{tabular}

1.2.1.3 cowst ment \& apreat, 3515

a no-f Imolnets on to

67 nu-f Dinects on to

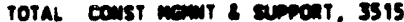

\begin{tabular}{rrrrrr}
105 & 0 & 105 & 110 & 0 & 110 \\
3 & 222 & 223 & 3 & 230 & 233 \\
\hline 100 & 222 & 330 & 113 & 230 & 343
\end{tabular}

1.2.1.6 TITLE III Enginetering, 3515

13 Wes TITLE III Ewe.

19 A-E TITLE III ENes.

TOTAL TITLE III ENGImething, 3515

\begin{tabular}{rrrrrr}
9 & 161 & 170 & 10 & 169 & 17 \\
0 & 43 & 43 & 0 & 45 & 45 \\
\hline 9 & 204 & 213 & 10 & 216 & 226
\end{tabular}

\footnotetext{
1.2 .2 Diloting 3515 o 20

69 mes FIELD MIUTEMAMcE

s) Pixco mate comstavetion
}

TOTAL CUILDIMG 3515 D 0

\begin{tabular}{lrrrrr}
209 & 1 & 300 & 316 & 1 & 315 \\
306 & 51 & 357 & 322 & 53 & 373 \\
\hline 605 & 52 & 657 & 436 & 36 & 600
\end{tabular}

1.2.2.1 ImItial CManactenizarion, 3515 51 Fixeo mice constaction

TOTal Imirial cmanactenizarion, 3513

\begin{tabular}{llllll}
6 & 26 & 30 & 6 & 25 & 31 \\
\hline 6 & 26 & 30 & 6 & 23 & 31
\end{tabular}

Fig. 5. Fourth-kevel project summary by WBS for complete dismantlement of Building 3515. 


\section{$0 \& 0063515$}

\section{semeanr netrout}

\section{$81=81000$}

$11 / 10 / 93$

Arrenend oy: was / Marticitemt

1.2.2.2 Eovimiat menoval, 3515 51 fixed mice constauction

Total Ecuimewt nevoval, 3515

1.2.2.3 oecontamimation, 3515 5) FILD mie: constenction

rotal Becominaimation, 3515

1.2.2.6 OImante stmetrue, 3515

51 Fixed mate consthuction

Total DImantLE stwartue, 3515

1.2.2.5 ClOAUnE, 3599

S1 Fixed mice coustmuction

TOTAL CLOANE, S5is

1.2 .3 .9 TEAATHEN, 3515

51 Fixed mice coustauction

TOTaL TaEaTnEmT, 3515

1.2.3.2 Mex/rnamsf to wes $\mathrm{m}, 3515$

51 FIXED Masce constauctio

total PaCx/TRAMBF to mes M. 3515

1.2.3.3 Disoosal of DLes 3515 mat'L

92 mste mannectuent

9 sereial

TOTAL DISHOSAL Of ELOG 3515 MAT'L

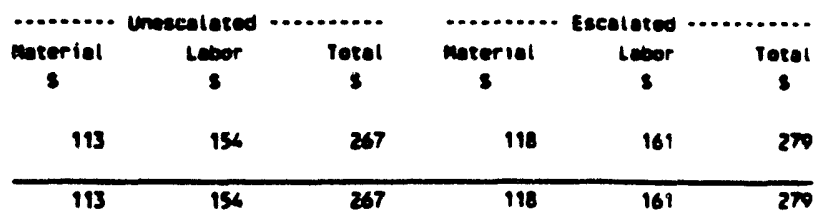

\begin{tabular}{llllll}
0 & 0 & 0 & 0 & 0 & 0 \\
\hline 0 & 0 & 0 & 0 & 0 & 0
\end{tabular}

\begin{tabular}{llllll}
40 & 00 & 138 & 51 & 5 & 160 \\
\hline 40 & 0 & 138 & 51 & $\$ 5$ & 146
\end{tabular}

\begin{tabular}{llllll}
6 & 3 & 9 & 6 & 3 & 9 \\
\hline 6 & 3 & 9 & 6 & 3
\end{tabular}

\begin{tabular}{llllll}
0 & 0 & 0 & 0 & 0 & 0 \\
\hline 0 & 0 & 0 & 0 & 0 & 0
\end{tabular}

\begin{tabular}{llllll}
2 & 2 & 4 & 2 & 2 & 4 \\
\hline 2 & 2 & 4 & 2 & 2 & 6
\end{tabular}

$\begin{array}{rrrrrrr}0 & 0 & 0 & 0 & 0 & 0 \\ 620 & 0 & 62 & 61 & 0 & 41\end{array}$

Fig. 5 (contimued) 


\section{- L d las 35is \\ sumer revout \\ $81 \cdot$ ereos \\ $11 / 10$ es}

Arrenow oy: Less / Particiment

as - Total

cart tmeener

cans torat

\begin{tabular}{|c|c|c|c|c|c|}
\hline \multicolumn{3}{|c|}{.......... unesestoted ........... } & \multicolumn{3}{|c|}{........... Eseoloted .... } \\
\hline $\begin{array}{c}\text { material } \\
\text { ? }\end{array}$ & Letor & $\begin{array}{c}\text { Posel } \\
\text { s }\end{array}$ & $\begin{array}{c}\text { Moterial } \\
\text { ? }\end{array}$ & Leor & 1otol \\
\hline $\begin{array}{r}1530 \\
503\end{array}$ & $\begin{array}{r}1146 \\
393\end{array}$ & $\begin{array}{r}26 \pi \\
0 \% 6\end{array}$ & $\begin{array}{r}1607 \\
520\end{array}$ & $\begin{array}{l}1100 \\
400\end{array}$ & $\begin{array}{r}27 \% 6 \\
037\end{array}$ \\
\hline 2033 & 1561 & 3576 & 2136 & 1597 & 3733 \\
\hline
\end{tabular}

Fiz 5 (continued) 
D 0 clog 3515, pantial

vemerer aterest

$51=81000$

$11 / 10 / 43$

Arreneed by: ws / Participent

1.2.1.1 moster imtenarion, 3515

69 mes monet etavicts

00 ER DIvision

rotal maset Intecarion, 3515

1.2.1.2 rithe 1 \& 11 Emolimetering, 3515

16 A-E TITLE 1 \& 11 Ewet.

40 unes $A-E$ eximear

TOTAL TITLE 1 \& 11 EmetmenaImG, 3515

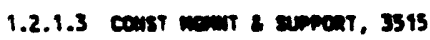

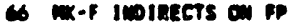

67 ux-F Dinects on FP
\end{abstract}

rotal const newt a enrout, 3595

1.2.1.6 TITL 111 Enolmenims, 3315

13 Wus TITLE 111 Emen.

19 A-E TITLE III Ewea.

. TOTAL TITLE III EmoImetaing, 3515

1.2.2 WILDING 3315 D 0 D. Pantial

69 MUES BIELO MAIMTEMAMCE

51 Fixed mice constauction

rotal miloime 3595 o s o, earrial

1.2.2.1 ImIrial Cumactentzarion, 3515 51 fixto mice constauction

rotal Imitial cmanactenizarion, 3515

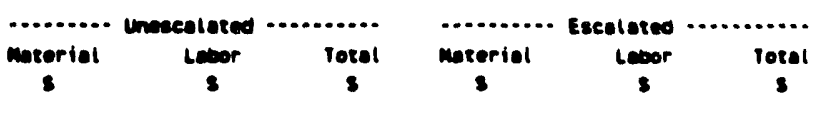

\begin{tabular}{rrrrrr}
0 & 163 & 163 & 0 & 160 & 160 \\
6 & 46 & 6 & 4 & 46 & 00 \\
\hline 4 & 227 & 231 & 4 & 236 & 230
\end{tabular}

\begin{tabular}{rrrrrr}
0 & 132 & 132 & 0 & 133 & 133 \\
0 & 66 & 6 & 0 & 67 & 67 \\
\hline 0 & 190 & 190 & 0 & 200 & 200
\end{tabular}

\begin{tabular}{rrrrrr}
115 & 0 & 115 & 120 & 0 & 120 \\
3 & 256 & 237 & 3 & 263 & 266 \\
\hline 118 & 236 & 352 & 123 & 263 & 346
\end{tabular}

\begin{tabular}{rrrrrr}
9 & 161 & 170 & 10 & 160 & 170 \\
0 & 43 & 43 & 0 & 45 & 45 \\
\hline 9 & 206 & 213 & 10 & 216 & 224
\end{tabular}

\begin{tabular}{llllll}
334 & 1 & 335 & 350 & 1 & 351 \\
306 & 31 & 357 & 322 & 53 & 375 \\
\hline 40 & 32 & 692 & 672 & 56 & 726
\end{tabular}

\begin{tabular}{llllll}
6 & 26 & 30 & 6 & 25 & 31 \\
\hline 6 & 26 & 30 & 6 & 25 & 31
\end{tabular}

Fig. 6. Fourth-level project summary by WBS for partial dismantlement of Building 3515. 
D 8 aleg 3515. Pantial

gumar expont

$81=81000$

11/10/s

Arrened ov: ins / Participant

1.2.2.2 Eevimint acimal, 3515 51 Fixisb mice constauction

TOTAL EeuImeNt RENoval, 3595

1.2.2.3 ofcomtamimation, 3sis 51 Fixed mice constwetio

Total DEComTanimation, 3515

1.2.2.6 DigmantLE stmetunE, 3515 51 FIxed mice coustauction

TOTAL DIEMANtE STMUCTLRE, 3515

1.2.2.5 closine, 3515

51 FIXED MAICE CONSTRUCTIOH

Total Closune, 3515

1.2.3.1 TREATment, 3515

51 Fixed mice constmuction

TOTAL TREATHENT, 3S15

1.2.3.2 PaCK/Tnansf to mes $\mathbf{m}, 3515$ 51 FIXED FRICE constauction

TOTAL PACx/thausf to mes M. 3515

\footnotetext{
1.2.3.3 DIEPosat OF OLDG 3515 maT'L 92 mste munetinim

๑ encial.
}

Toral Digecesel of DLog 3515 mat'L

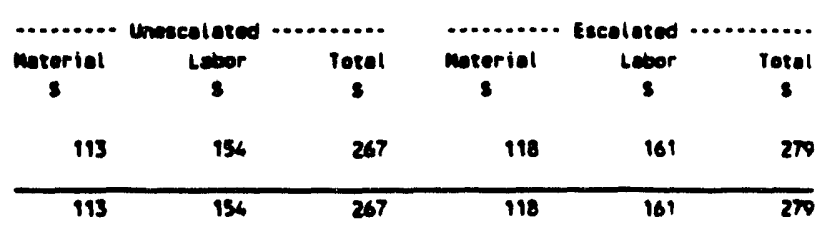

\begin{tabular}{llllll}
22 & 23 & 45 & 23 & 26 & 67 \\
\hline 22 & 23 & 43 & 23 & 26 & 67
\end{tabular}

\begin{tabular}{lllllll}
30 & 65 & 123 & 40 & 00 & 129 \\
\hline 38 & 05 & 123 & 40 & 09 & 120
\end{tabular}

\begin{tabular}{llllll}
6 & 3 & 9 & 6 & 3 & 9 \\
\hline 6 & 3 & 9 & 6 & 3 & 9
\end{tabular}

\begin{tabular}{llllll}
43 & 1 & 46 & 45 & 1 & 46 \\
\hline 43 & 1 & 46 & 45 & 1 & 46
\end{tabular}

\begin{tabular}{llllll}
2 & 2 & 4 & 2 & 2 & 4 \\
\hline 2 & 2 & 4 & 2 & 2 & 6
\end{tabular}

\begin{tabular}{rrrrrr}
19 & 0 & 19 & 20 & 0 & 20 \\
467 & 0 & 467 & 491 & 0 & 691 \\
\hline 486 & 0 & 486 & 511 & 0 & 511
\end{tabular}

Fif. 6 (continued) 


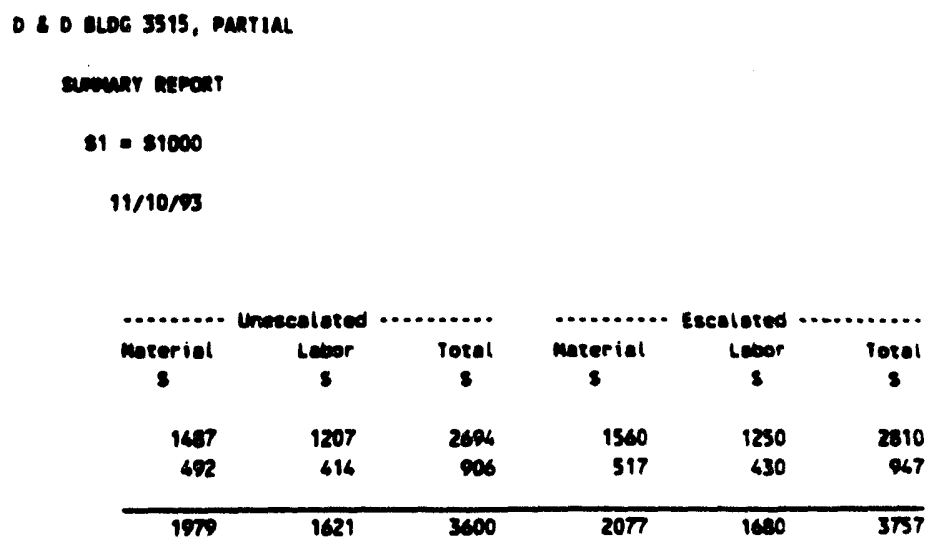

\begin{tabular}{|c|c|c|c|c|c|}
\hline ...... & calotec & $\ldots$ & $\cdots$ & bloted & \\
\hline moterial & Lever & $\begin{array}{c}\text { Total } \\
8\end{array}$ & $\begin{array}{c}\text { material } \\
\text { s }\end{array}$ & Leoor & $\begin{array}{c}\text { 10201 } \\
8\end{array}$ \\
\hline $\begin{array}{r}1407 \\
492\end{array}$ & $\begin{array}{r}1207 \\
616\end{array}$ & $\begin{array}{r}2604 \\
9006\end{array}$ & $\begin{array}{r}1560 \\
517\end{array}$ & $\begin{array}{r}1230 \\
430\end{array}$ & $\begin{array}{r}2810 \\
967\end{array}$ \\
\hline
\end{tabular}

Fit. 6 (continued) 
Appendix A.

Cost Estimate for

Partial Dismantlement of Building 3506 
SUmuRY REPont

Project Mumber: 930031.1

D 0 LLDG 3506, PARTIAL

Projeet Eso Muber.......

Revision Musear..........0

Lest Lpdate.............11/10/93

Sort Order

1. Whs

2. Participent

Approved by:

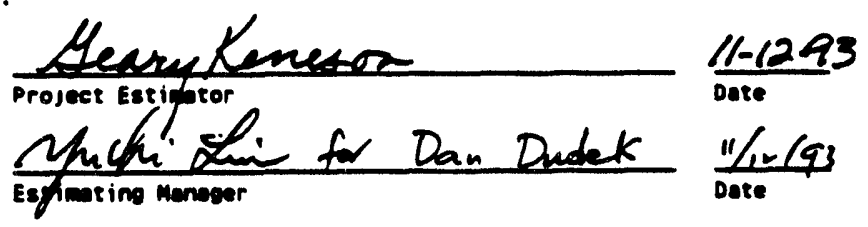

AES Version $5.2 e$

Bese fiscel Year/oumrtor: $93 / 6$

STAMDAED VALUE: CRER193.vel EXPIRES: OL/20/9\%

ESTIMATE FILE: D: WAES52CIX10U3506P.est $11 / 10 / 93$

SCMEDULE FILE: 3506 P

REPORT FILE : D: WAES52CIX10L3506P5. out 11/10/93 16:53:53 
D 0 llog 3506, partial.

\section{ExmunY RENont}

$$
s 1=\$ 1000
$$

$11 / 10 / 93$

Arreneed or: uss / Participant

1.1.1.1 Phosect Integarion, 3506 49 mies project seRvices

90 ER DIVIsion

TOTAL PROJECT INTEezation, 3506

1.1.1.2 TITLE I I II EngineERImG, 3506 18 A-E TITLE 1 \& II ENE.

48 miss $A-E$ supent

TOTAL TITLE I \& 11 ENGIMEERING, 3506

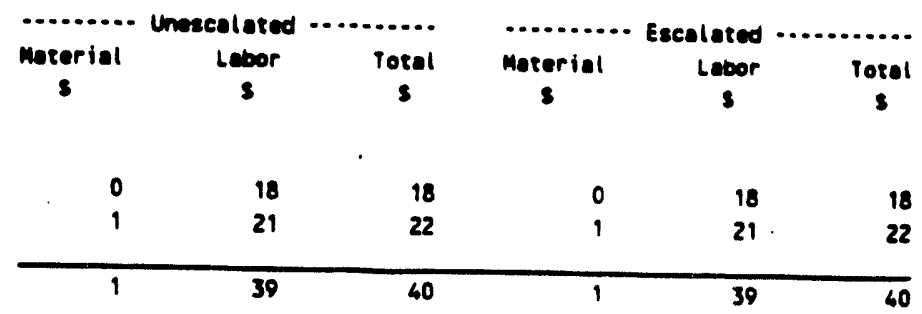

1.1.1.3 coust nemit \& Eppont, 3506 66 MK-F Imoineets on FP

67 MK-F DIRECTS on

total const nemit a sepont, 3506

1.1.1.6 TITLE III EMGIMEERIMG, 3506

13 mes tITLE 111 EMER.

19 A-E TITLE III EMrA.

totAl tITLE III EMGIMEERING, 3506

\begin{tabular}{rrrrrr}
0 & 26 & 26 & 0 & 24 & 26 \\
0 & 8 & 8 & 0 & 8 & 8 \\
\hline 0 & 32 & 32 & 0 & 32 & 32
\end{tabular}

\begin{tabular}{rrrrrr}
16 & 0 & 16 & 15 & 0 & 15 \\
0 & 32 & 32 & 0 & 32 & 32 \\
\hline 16 & 32 & 46 & 15 & 32 & 47
\end{tabular}

\begin{tabular}{rrrrrr}
2 & 27 & 29 & 2 & 28 & 30 \\
0 & 7 & 7 & 0 & 7 & 7 \\
\hline 2 & 36 & 36 & 2 & 35 & 37
\end{tabular}

1.1.2 BUILDIMG 3506 D \& D, PARTIAL

41 mES FIELD MINTEMANCE

51 FIXED PRICE COAsThuction

TOTAL BUILOIMG 3506 D $\&$ D, PARTIAL

\begin{tabular}{rrrrrr}
112 & 1 & 113 & 115 & 1 & 116 \\
33 & 36 & 69 & 36 & 37 & 71 \\
\hline 145 & 37 & 182 & 149 & 38 & 187
\end{tabular}

1.1.2.1 IMITIAL CMAMACtERIzation, 3506 51 FIXED PRICE COUsTRUCTIOY

TOTAL INITIAL CMARACTERIZATION, 3506

\begin{tabular}{llllll}
2 & 7 & 9 & 2 & 7 & 9 \\
\hline 2 & 7 & 9 & 2 & 7 & 9
\end{tabular}


D 2 oldog 350s, partial

sumunr nepont

$81 \cdot 81000$

$11 / 10 / 93$

Arrenead Dy: wes / Participent

1.1.2.2 EeUImENT REMoval, 3506 51 FIXED PRICE constmuction

TOTAL EOUIAMENT REMOVAL, 3506

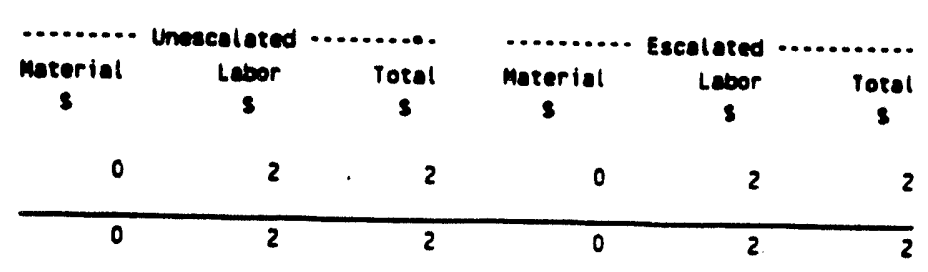

1.1.2.3 Decowtamimation, 3506

51 FIXeD mice constauetion

TOTAL DEContamimation, $3506^{\circ}$

\begin{tabular}{|c|c|c|c|c|}
\hline 1 & 2 & 3 & 1 & 2 \\
\hline 1 & 2 & 3 & 1 & 2 \\
\hline
\end{tabular}

1.1.2.4 DIEMATLE STRUCTURE, 3506

51 FIXED PRICE COAstRuetion

TOTAL DIgmante sthuctune, 3506

\begin{tabular}{llllll}
5 & 11 & 16 & 5 & 11 & 16 \\
\hline 5 & 11 & 16 & 5 & 11 & 16
\end{tabular}

1.1.2.5 Closune, 3506

S1 FIXEO mice constauction

Total Closume, 3506

1.1.3.1 Theatment, 3506

51 FIXED PRICE constauction

rotal tREATMENT, 3506

1.1.3.2 PACK/TRAMSF TO mes in, 3506 51 FIXed phIEe construction

rotal PACK/TRAMSF to mes IM, 3506

\begin{tabular}{llllll}
1 & 1 & 2 & 1 & 1 & 2 \\
\hline 1 & 1 & 2 & 1 & 1
\end{tabular}

1.1.3.3 DISPOSAL OF IOG 3506 mir'L

92 MASTE MAMACENENT

9 spectal

TOTAL DISPOSAL OF BLDG 3506 mT'L

\begin{tabular}{rrrrrr}
0 & 0 & 0 & 0 & 0 & 0 \\
326 & 0 & 326 & 335 & 0 & 335 \\
\hline 326 & 0 & 326 & 335 & 0 & 335
\end{tabular}




\section{- 0 oldo 3306, partial \\ amine nereer}

$\$ 1=\$ 1000$

$11 / 10 / 93$

Arrenued or: uss / Participent

su - Total

continesnCy

GRAND TOTAL

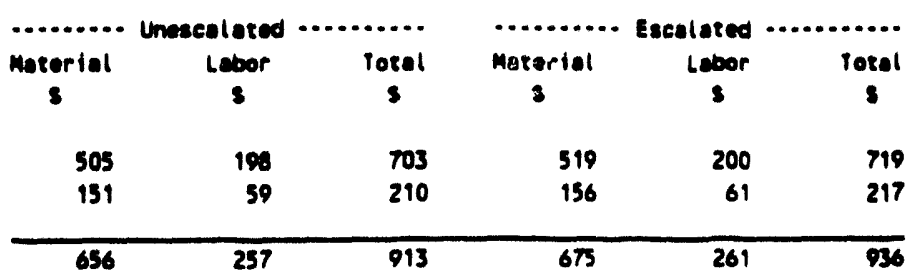


Detall Remont

Project Meroer: 930031.1

D 0 ILDG 3506, PARTIAL

Project 280 Muber.......

Revision Mubar..........0

Lest upente.............11/10/93

Sorz order

1. wos

2. Participant

3. em Aetribute

Approved by:

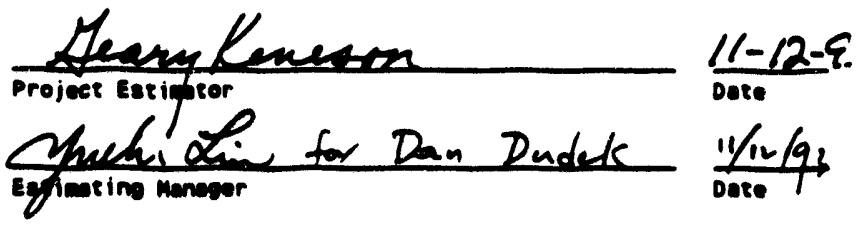

AES Version $5.2 \mathrm{e}$

lose fiscal Yeor/ouprear: $93 / 4$

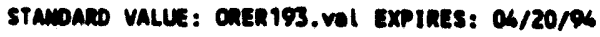

ESTIMATE FILE: O: VAES52CIX1013506P.eat $11 / 10 / 93$

SCMEDULE FILE: 3506 P

MEPORT PILE : $0:$ WES52CIX10U3506P0.out 11/10/93 16:48:51 
Creation Dote ...... 08/18/93

nevision llumer ... 0

Project Estinator.. G KEnEson

WS ............. 1.1.1.1 PhOJECT InTEenATIOW, 3506

Cose cocs ........ 9100 Phosect InTEenation

Participant ...... 49 mis movect senvices

Contreceting ive ... 6

BM Aterlbute ..... X1.1.18 mes project seavices

Diseipline ......... Engineoring

b/M ritle ......... mas mosect senvices

Receiving site ..... $x-10$

stendard value file calerig.vel

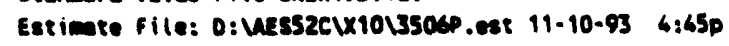

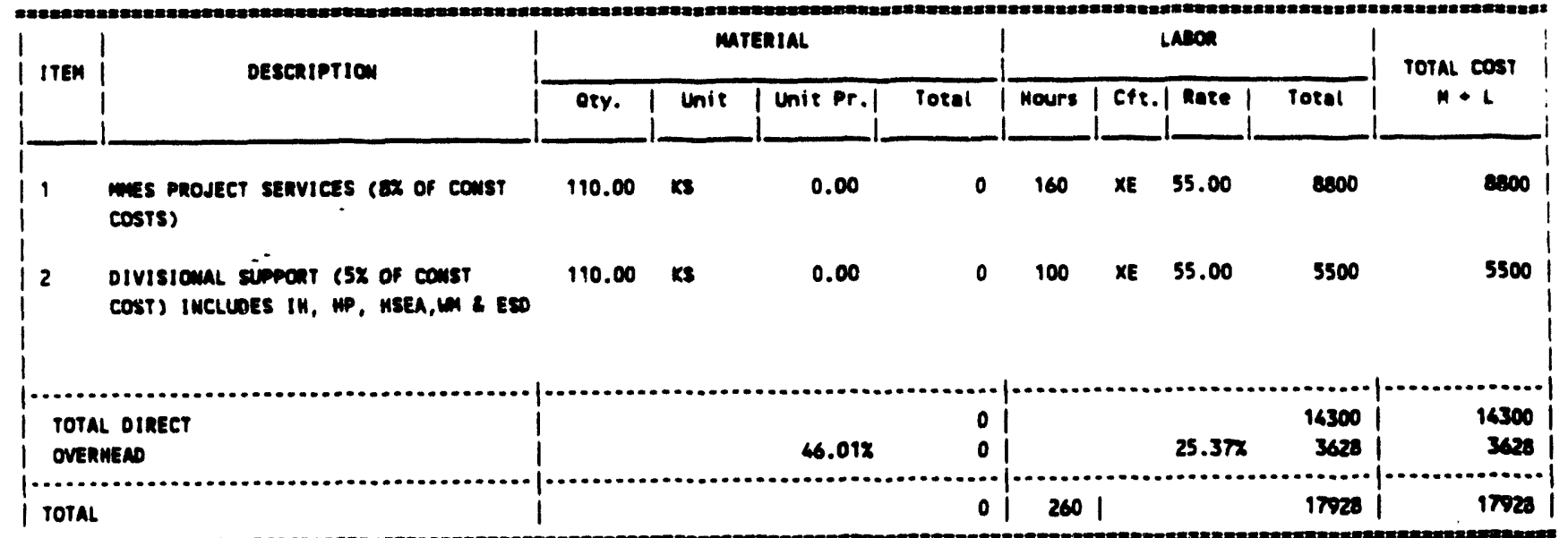

Estranting dob Mumber .. 4225.620

Project Enginear ........ SMEDAKER

Building/are .......... 3506

plent sise ..............

Lewl of Estiente ....... P

funding irpe ........... Expense

source site ............ X-10

oiscipline Estinetor ... wax

Quentity Take-oft oy ... wex

Trece Mumer ............. X.1.2 0

Expiration Date: $06 / 20 / 96$ 
D 80 llDg 3506, partial.

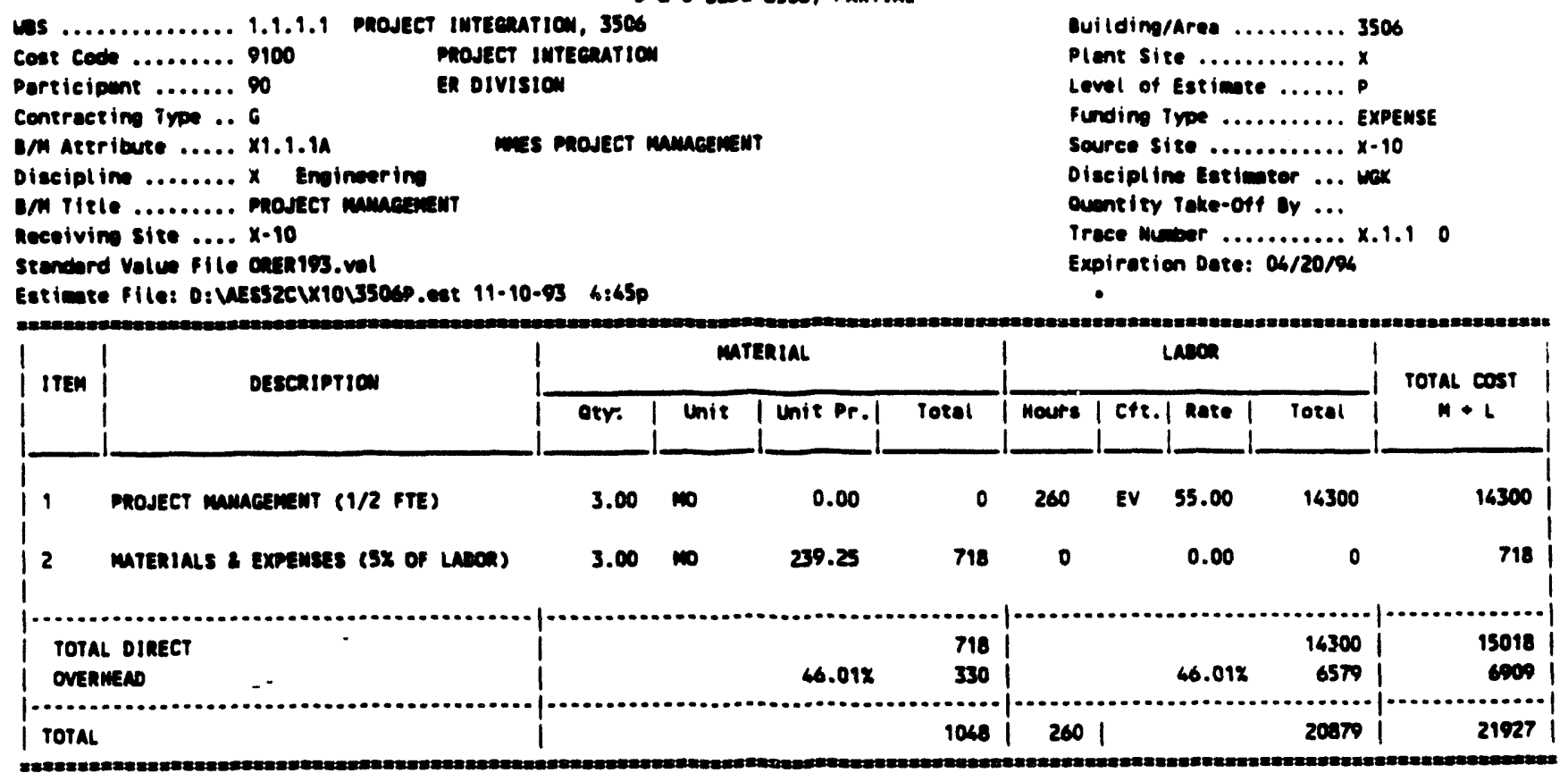


- 20 llog 350s, partial

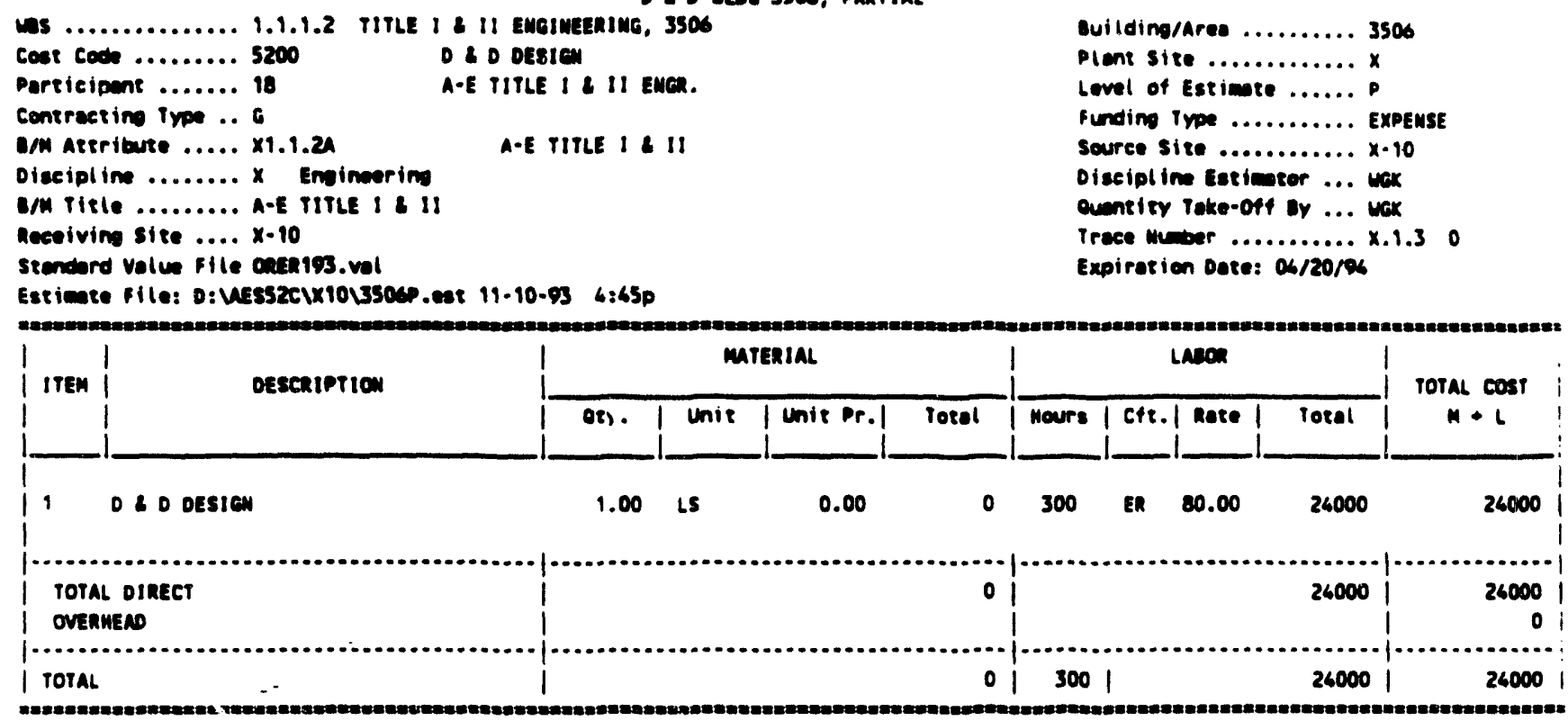


D 2 D lag 3506, partial

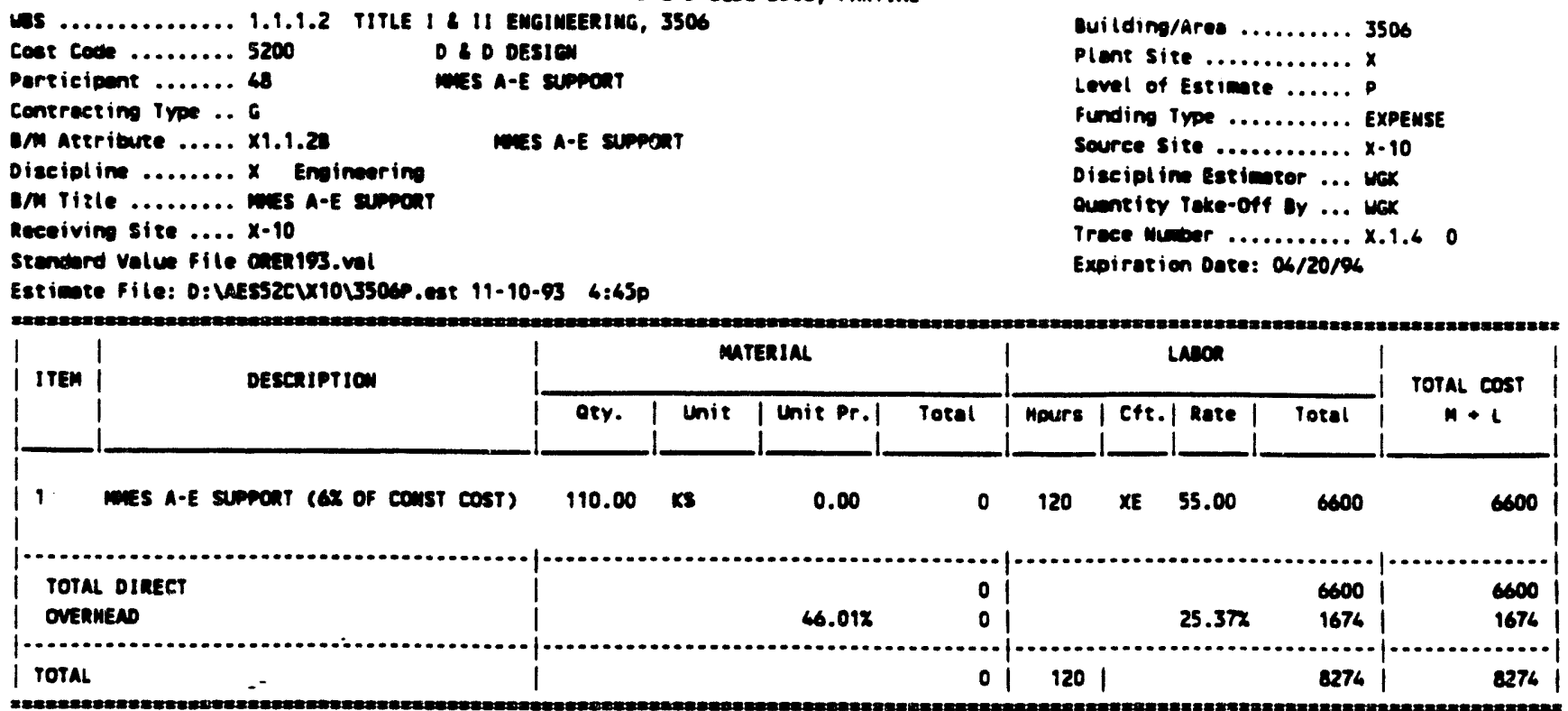




\section{D \& D LLDG 3506, PARTIAL}

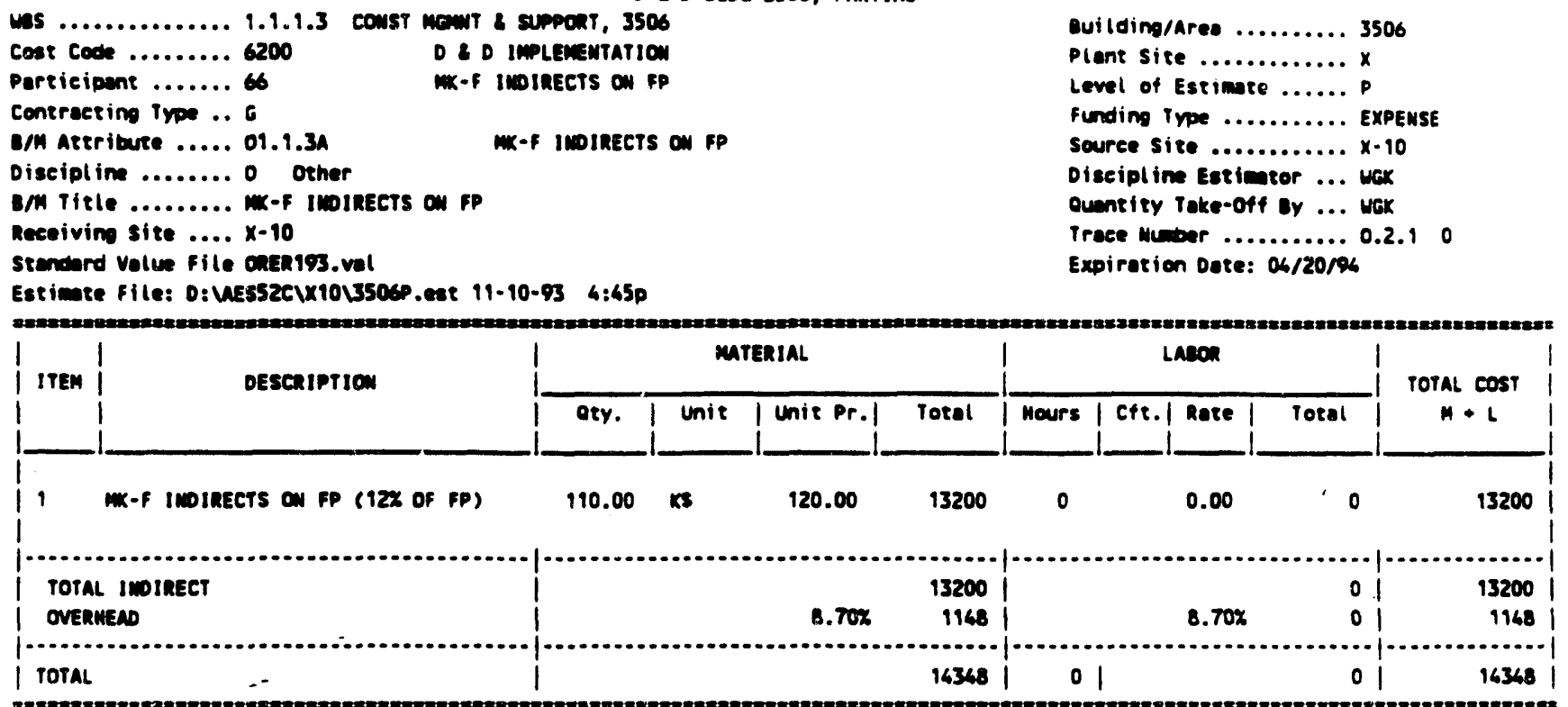


- 20 llog 3506, PARTIAL

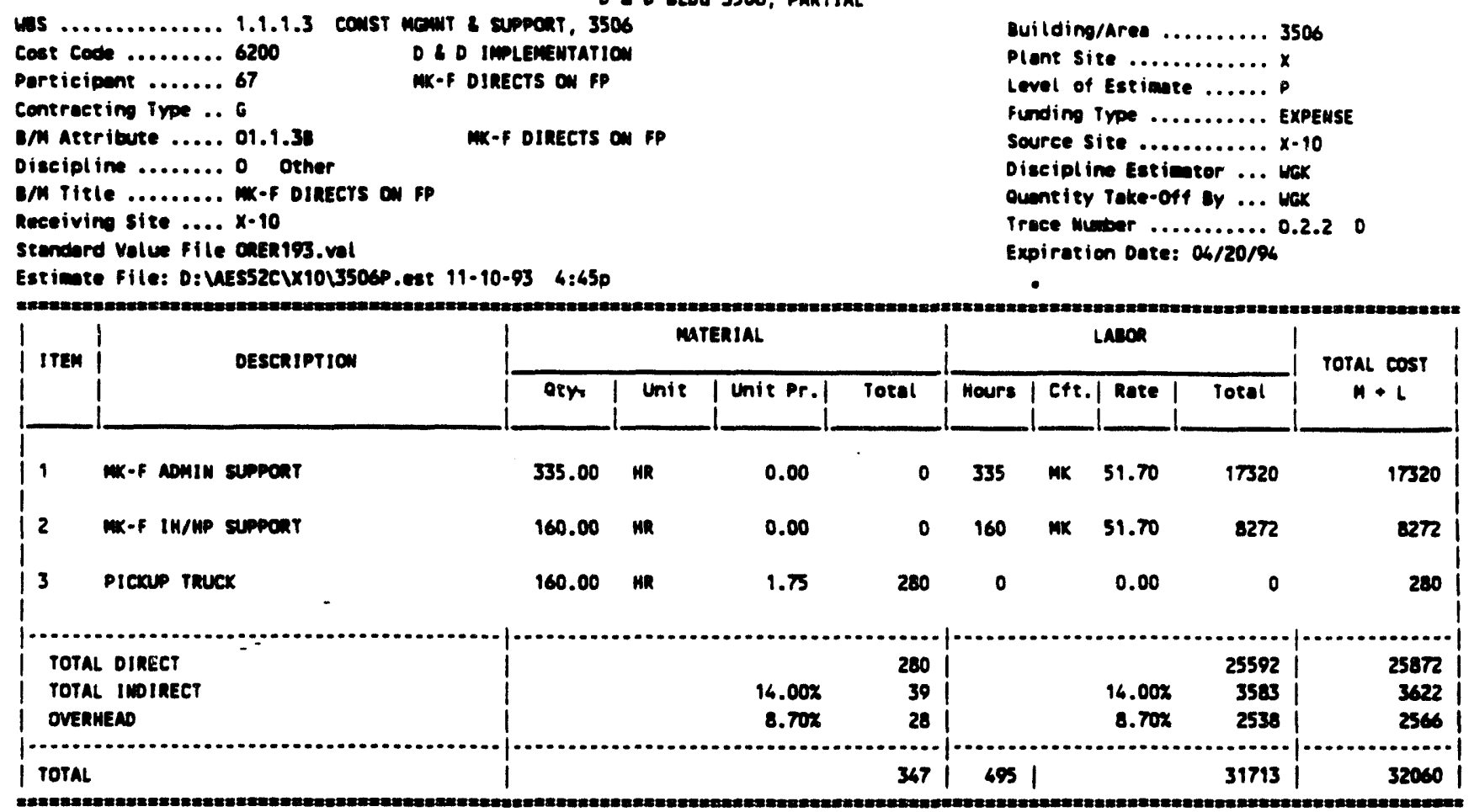


D 20 ILDG 3506, PARTIAL

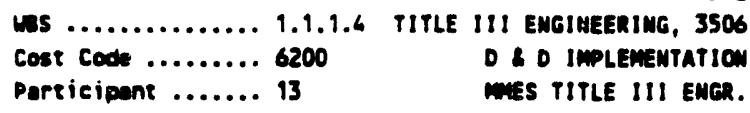

Contracting ivpe .. 6

B/M Attribute ...... X1.1.4A

Discipline ......... $\times$ Enginsering

im ritle .......... MuEs TITLE III

Reeciving site .... $\times 10$

Stendord Value fille Cate193.val

Estimete file: D: WEs52C1X1013506p.est 11-10-93 4:45p

\begin{tabular}{|c|c|c|c|c|c|c|c|c|c|c|}
\hline \multirow{2}{*}{ ITEM } & \multirow{2}{*}{ DESCRIPTIOW } & \multicolumn{4}{|c|}{ MATERIAL } & \multicolumn{4}{|c|}{ LABOD } & \multirow{2}{*}{$\begin{array}{c}\text { TOTAL } \cos T \\
M+L\end{array}$} \\
\hline & & oty. & Unit & Unit Pr.l & Total & Hours & cft. 1 & Rote | & Total & \\
\hline 1 & $\begin{array}{l}\text { MESS TITLE III ENGIMEERIMG }(1-1 / 2 \\
\text { FTE) }\end{array}$ & 1.50 & no & 0.00 & 0 & 390 & $X E$ & 55.00 & 21450 & 21450 \\
\hline 2 & MATERIALS \& EXPENSES (5X OF LABOR) & 1.50 & no & 715.00 & 1073 & 0 & & 0.00 & 0 & 1073 \\
\hline $\begin{array}{l}\text { TOTA } \\
\text { OVER }\end{array}$ & $\begin{array}{l}\text { L DIRECT } \\
\text { HEAD }\end{array}$ & & & $46.01 \%$ & $\begin{array}{r}1073 \\
494\end{array}$ & & & 25.377 & $\begin{array}{r}21450 \\
5462\end{array}$ & $\begin{array}{r}22523 \\
5936\end{array}$ \\
\hline TOTAL & & & & & 1567 & 390 & & & 26092 & 28459 \\
\hline
\end{tabular}

Building/area .......... 3506

Plent site ............. $x$

Level of Estimate ....... P

funding ippe ........... EXPEMSE

Source site ............ $\times 10$

Discipl ine Estimeror ... WGX

Quentity Take-off by ... Wax

Trace wuber ............ X.1.5 0

Expiration Date: $04 / 20 / 96$ 
D 0 DlOg 3506, PARTIAL

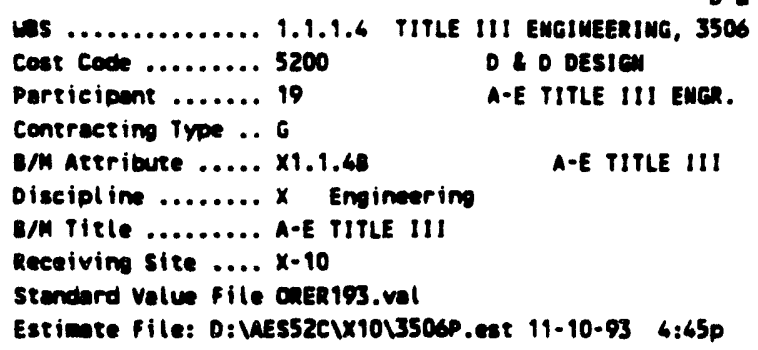

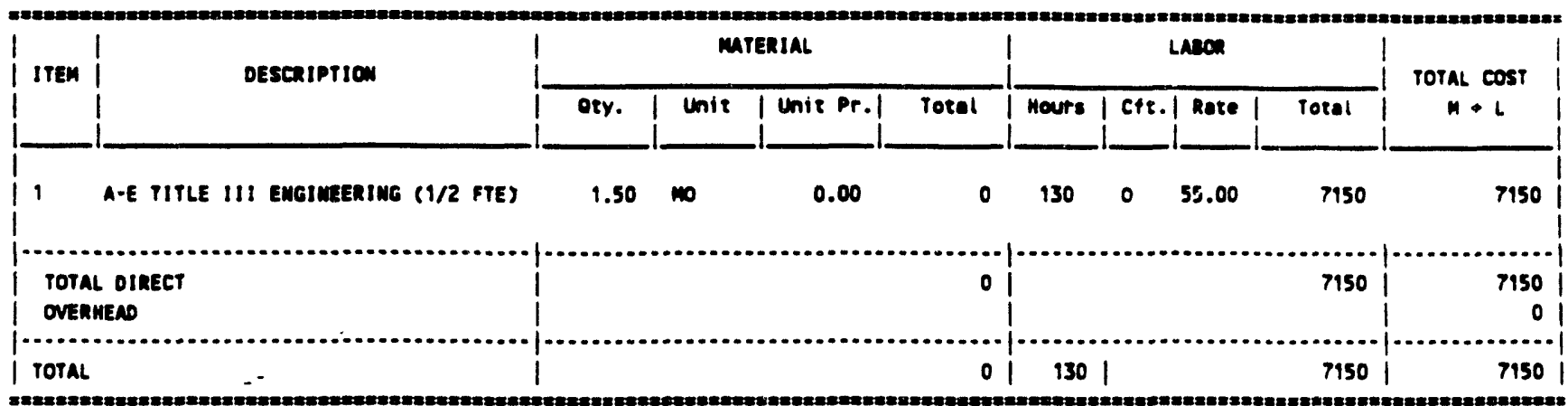

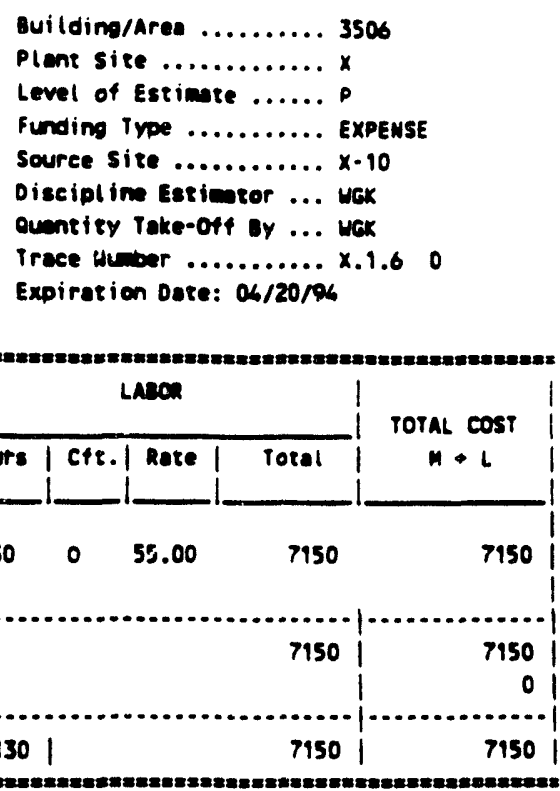


D 0 llog 350s, partial

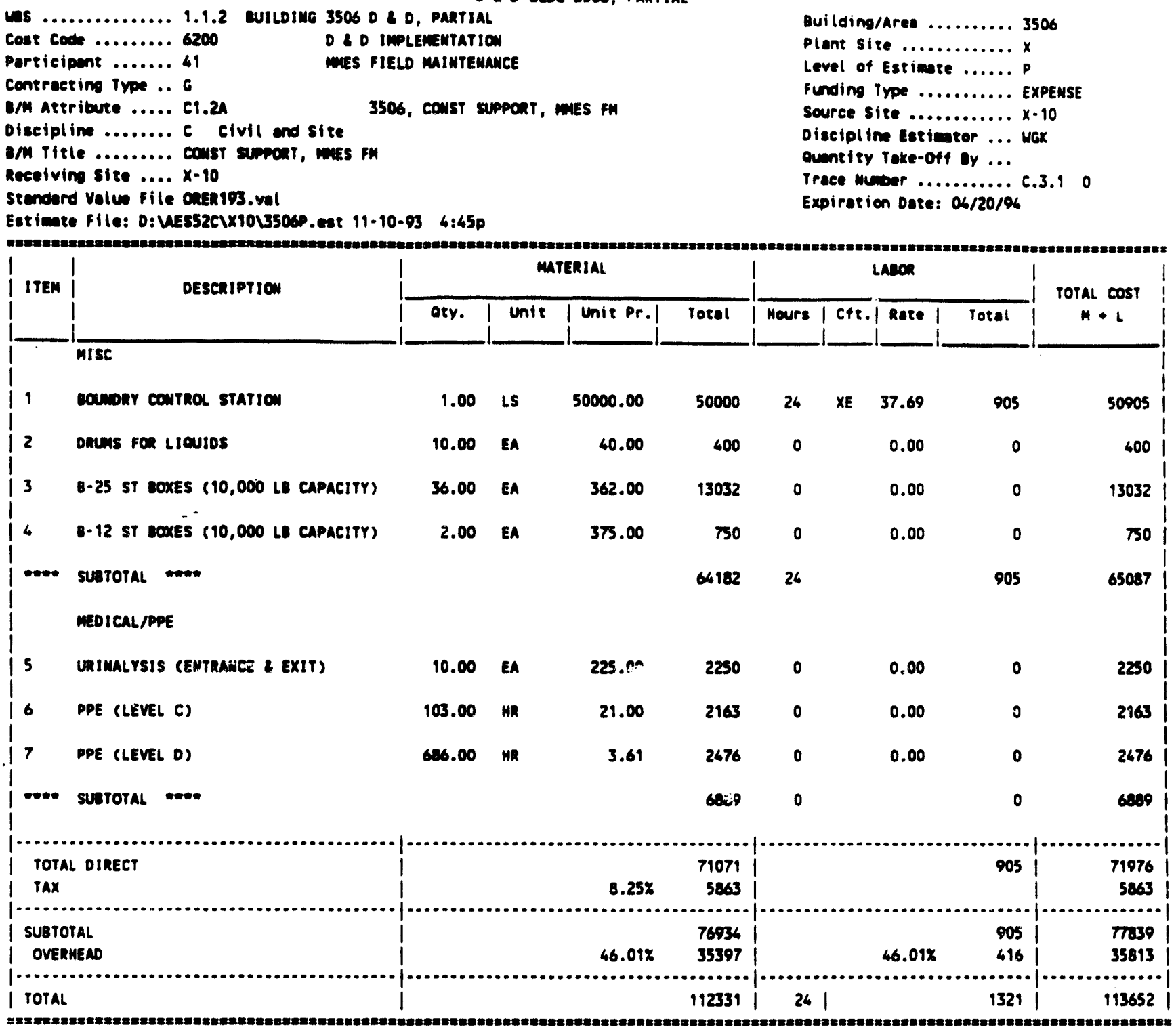


D 2 o clog 3506, PARTial

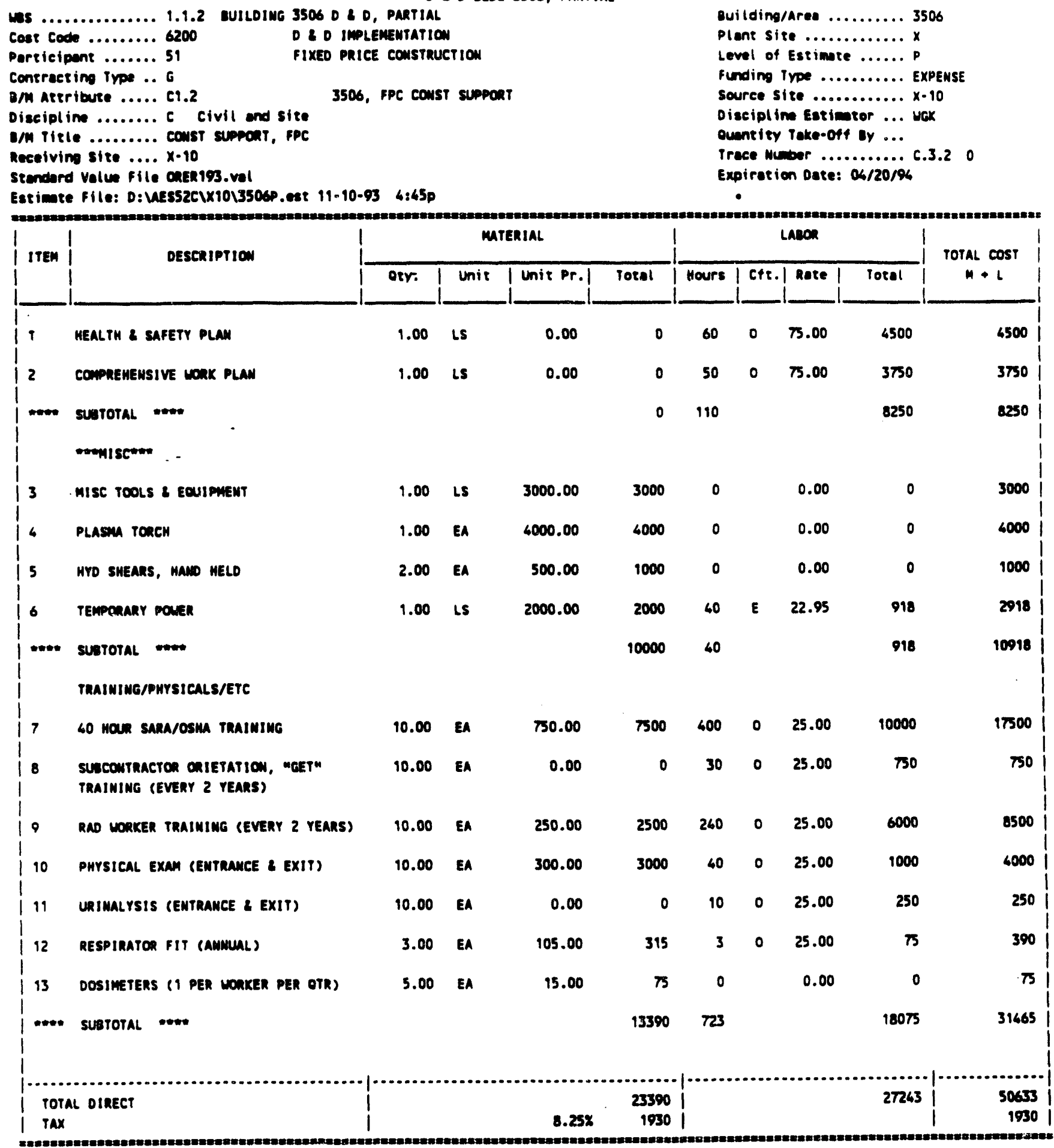


D 0 UlOg 3506, PARTIAL

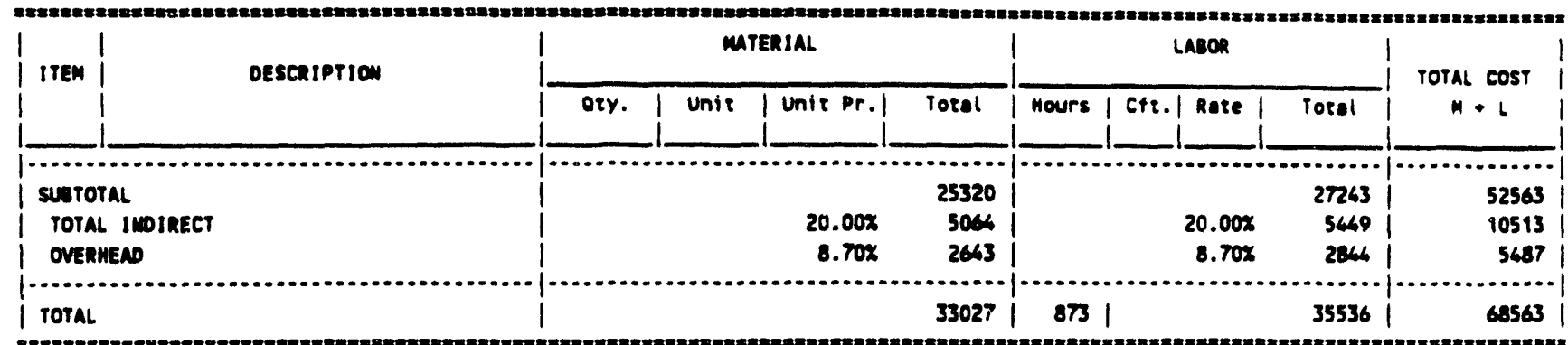

873

68563

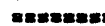


D 6 DLOg 3506, partial

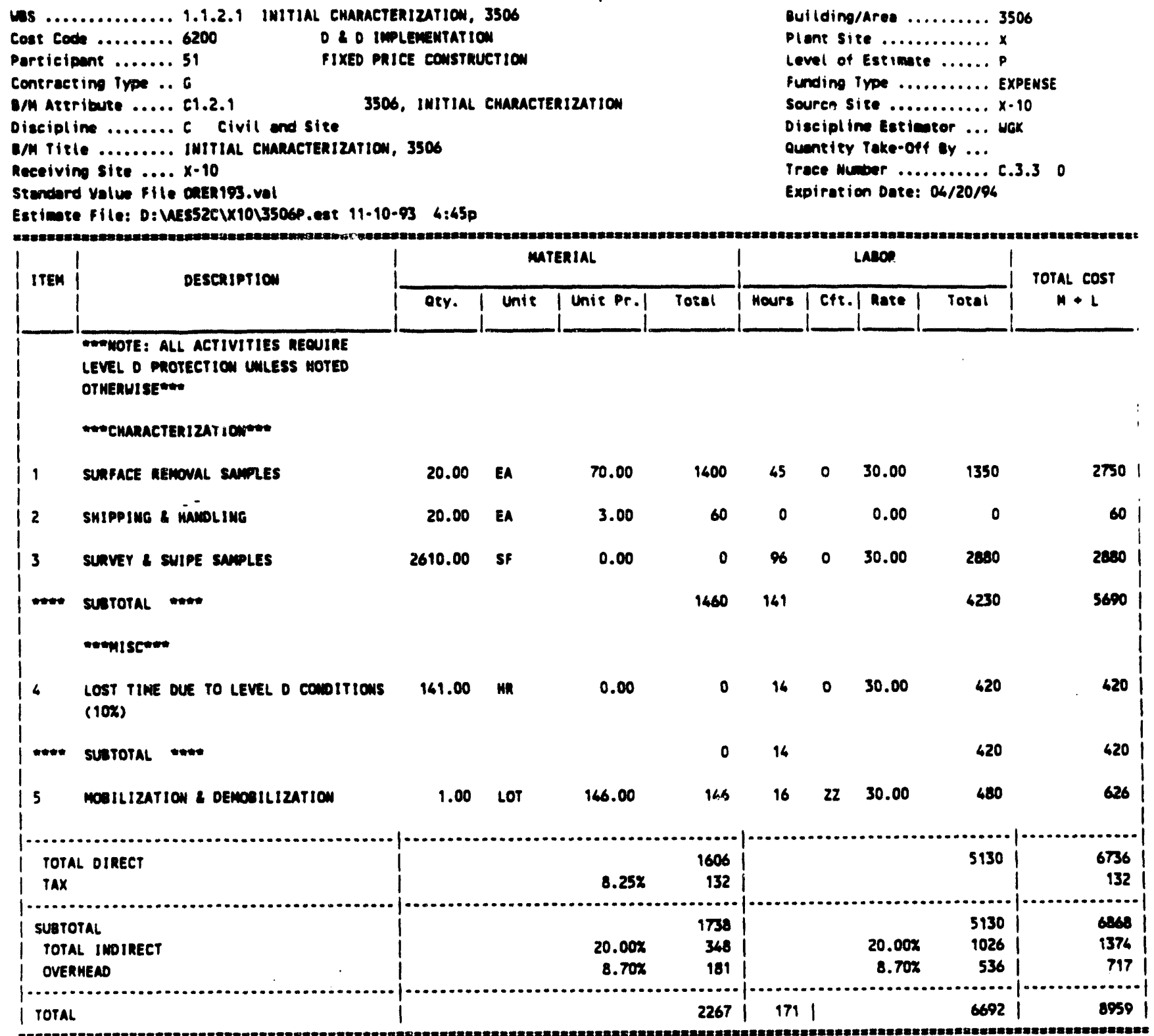




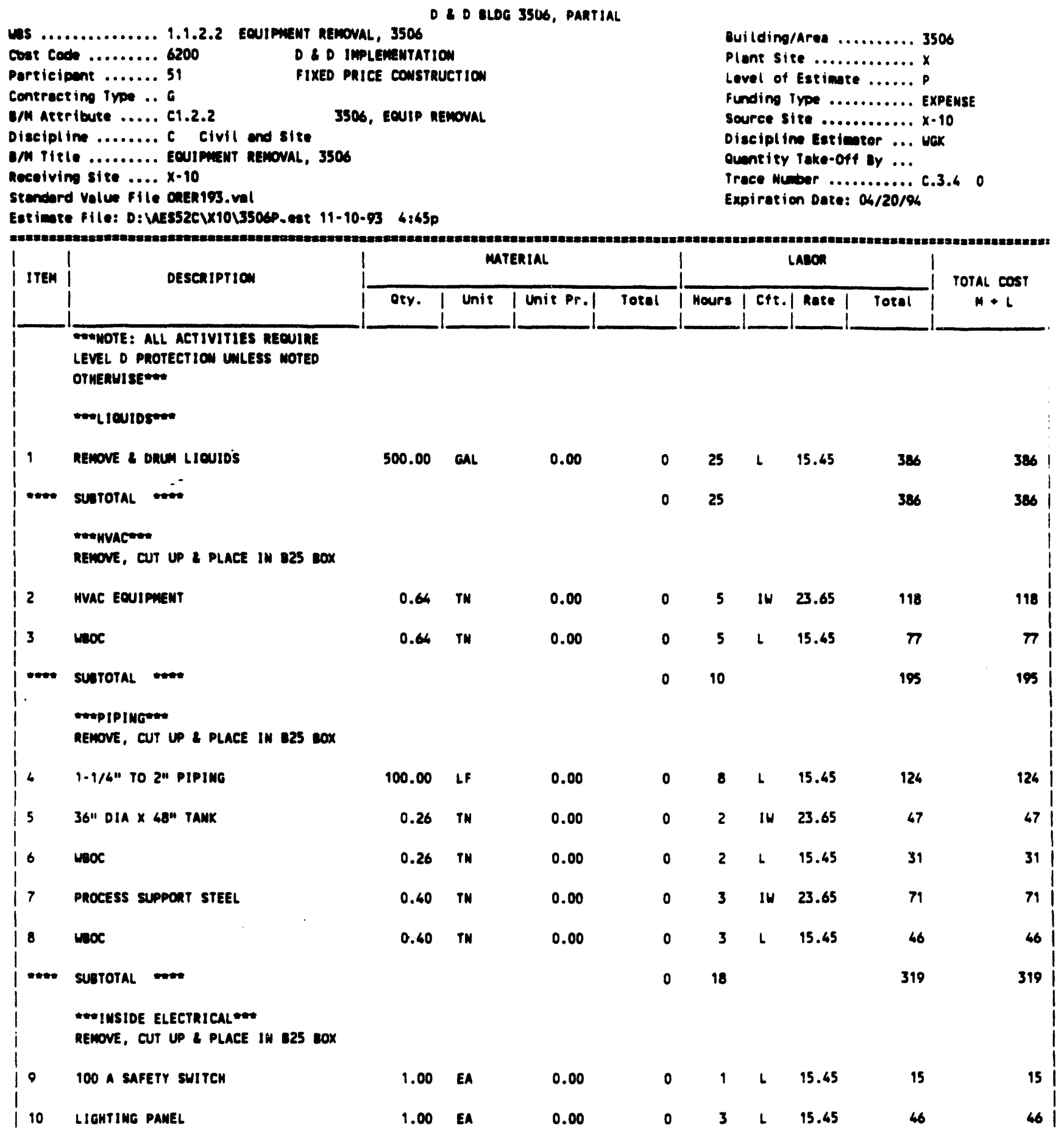


D 20 LlDG 3506, PARTIAL

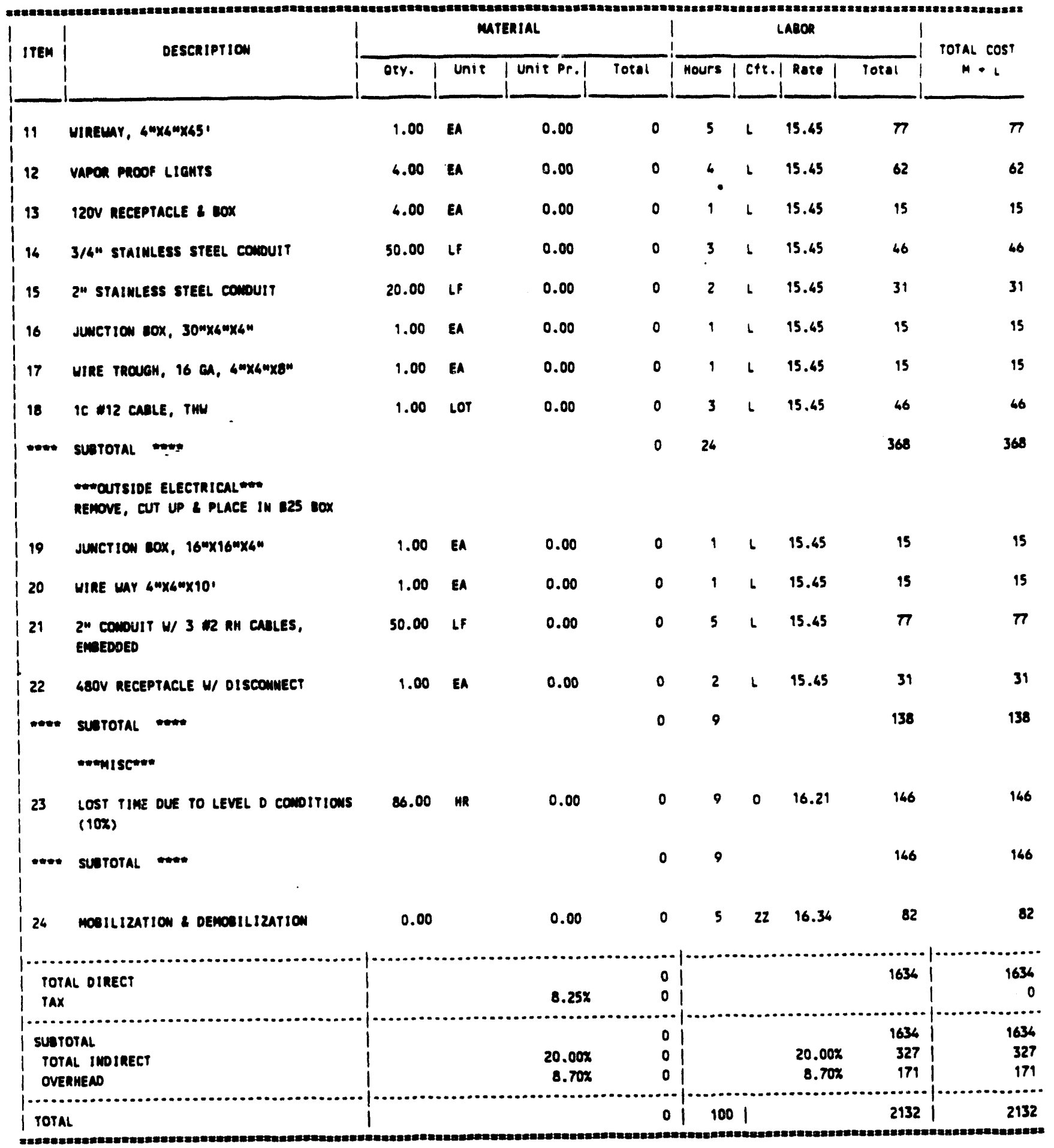


D I LlOG 3506, PARTIAL

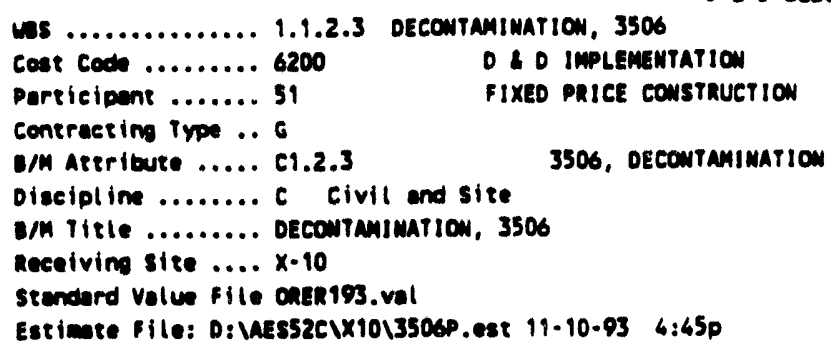

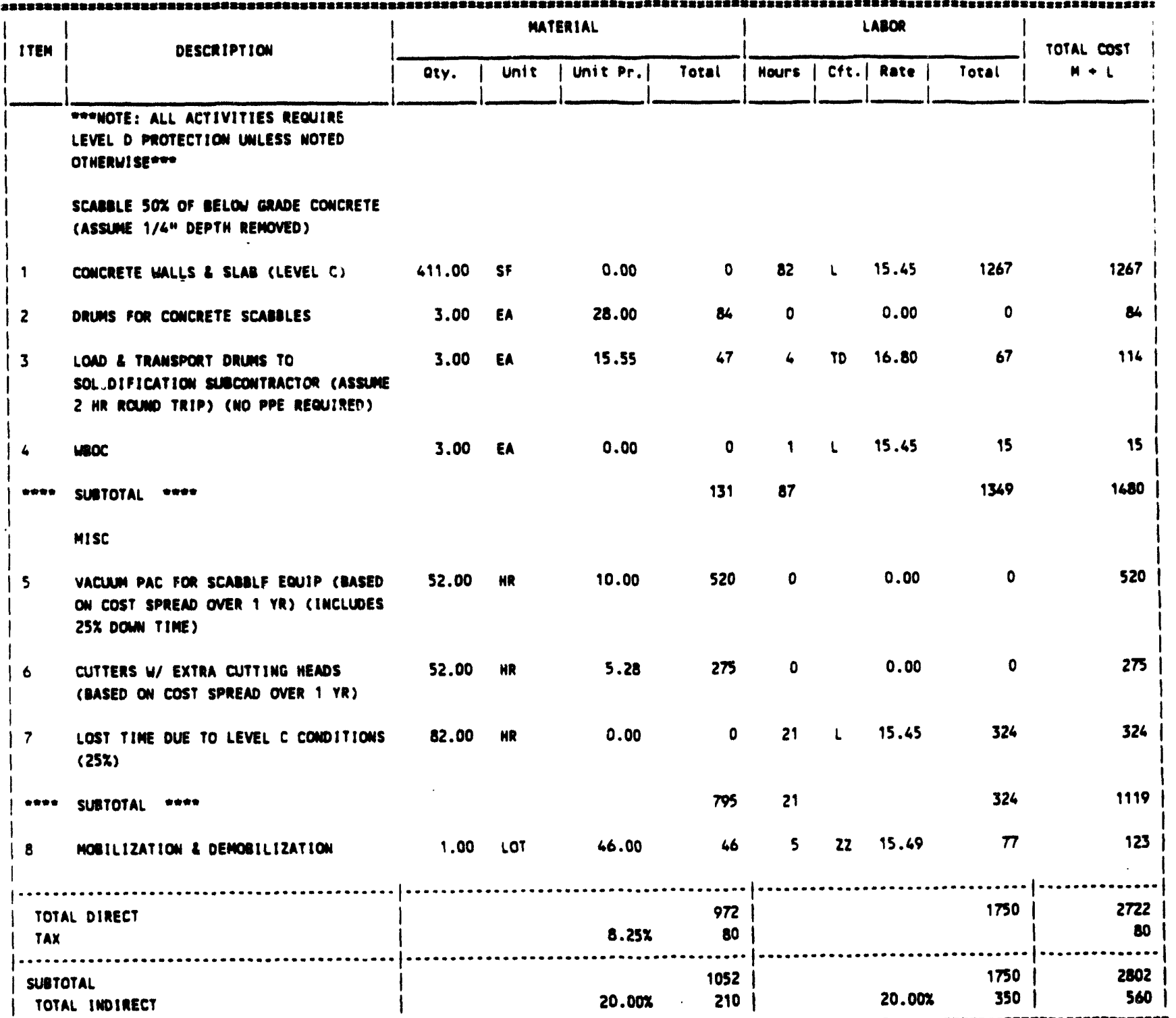

I TOTAL INOTREC?

$20.00 \% \quad 210$

$20.00 x \quad 350$

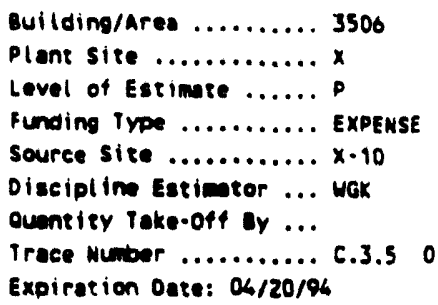


D 0 olDg 3506, PARTIAL

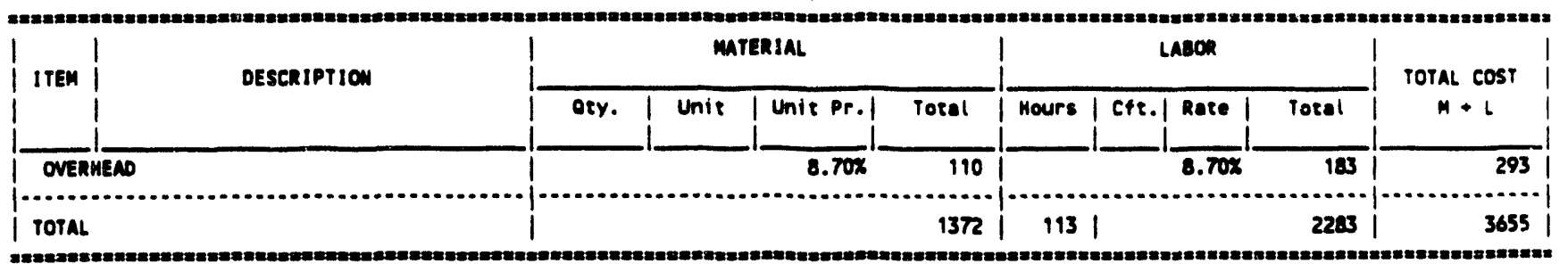


D O BLDG 3506, PARTIAL

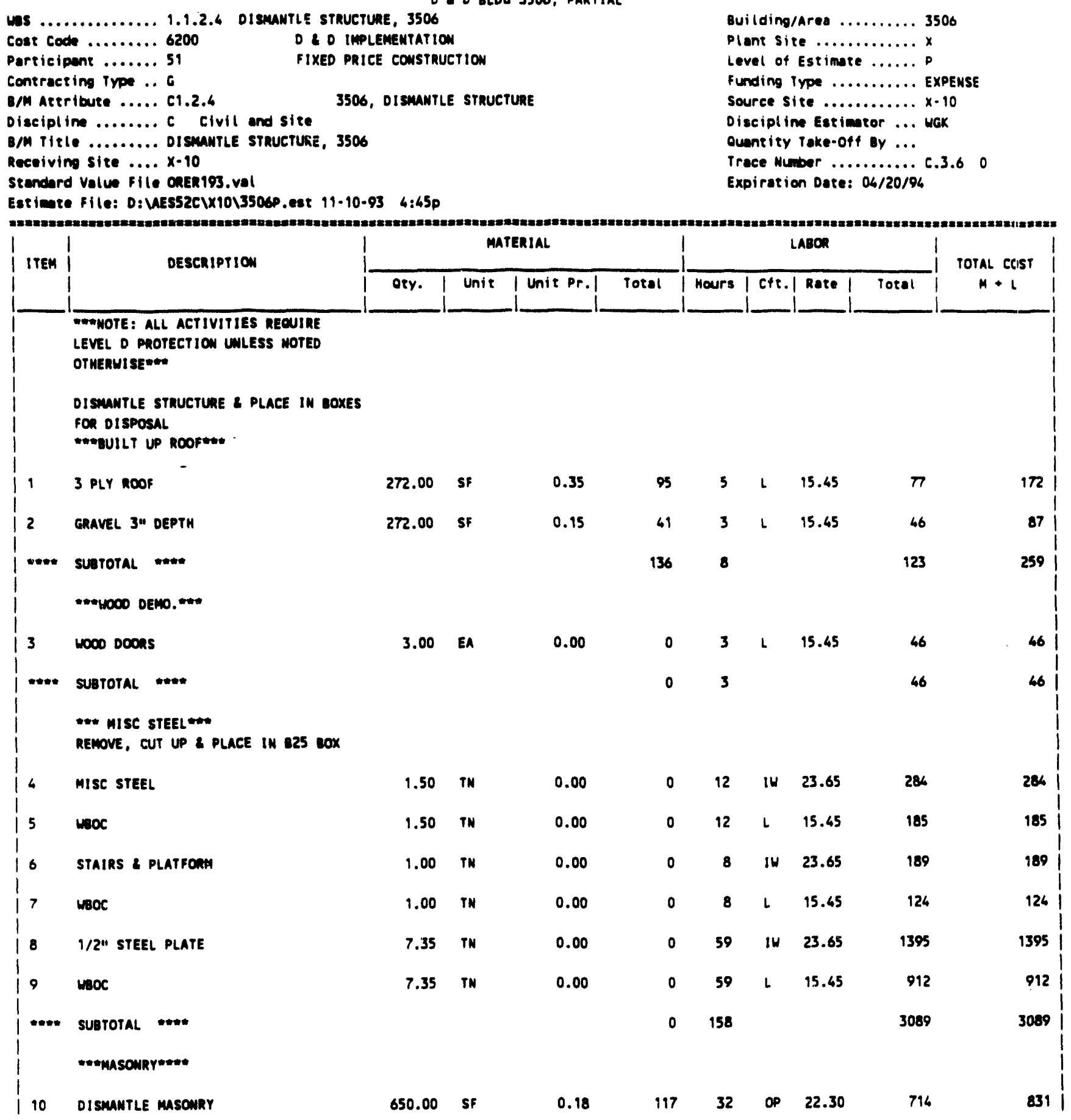


D 10 BLOG 3506, PARTIAL

\begin{tabular}{|c|c|c|c|c|c|c|c|c|c|c|}
\hline \multirow{2}{*}{ ITEM } & \multirow{2}{*}{ DESCRIPTION } & \multicolumn{4}{|c|}{ material } & \multicolumn{4}{|c|}{ LABOR } & \multirow{2}{*}{$\begin{array}{c}\text { TOTAL Cost } \\
M+L\end{array}$} \\
\hline & & aty. & Unit & Unit Pr.l & Total & Hours & Cft.l & | Rate | & Total & \\
\hline 11 & PLACE MASONRY IN B-25 BOXES & 20.50 & CY & 2.02 & 49 & 2 & OP & 22.30 & 45 & 86 \\
\hline intent & SUSTOTAL & & & & 158 & 36 & • & & 759 & 917 \\
\hline 12 & CONCNETE MALLS & 116.00 & CY & 23.60 & 2738 & 58 & OP & 22.30 & 1293 & 4031 \\
\hline 13 & woc & 116.00 & CY & 0.00 & 0 & 116 & $L$ & 15.45 & 1792 & 1792 \\
\hline 16 & $\begin{array}{l}\text { BACKFILL. \& COAPACT PIT MITH COMCNETE } \\
\text { RUBSLE (TS MP FE LOADER \& VIBRATIMG } \\
\text { ROLLER) }\end{array}$ & 36.00 & CY & 0.46 & 17 & 1 & $O P$ & 22.30 & 22 & 39 \\
\hline 15 & $\begin{array}{l}\text { PLACE REMAIMING CONCRETE RUBBLE IN } \\
\text { B-25 BOXES }\end{array}$ & 80.00 & CY & 2.02 & 162 & 7 & $O P$ & 22.30 & 156 & 318 \\
\hline$m$ & sustotal & & & & 2917 & 182 & & & 3263 & 6180 \\
\hline 16 & $\begin{array}{l}\text { LOST TIME OUE TO LEVEL D COMITIOAS } \\
(10 \%)\end{array}$ & $387.0 \mathrm{r}$ & & 0.00 & 0 & 39 & 0 & 18.86 & 736 & 736 \\
\hline$\infty$ & SUBTOTAL & & & & 0 & 39 & & & 736 & 736 \\
\hline 17 & mosilization \& dEMOSILIZATION & 1.00 & LOT & 161.00 & 161 & 21 & $\mathbf{2 2}$ & 18.91 & 397 & 558 \\
\hline Tota & L DIRECT & & & & 3372 & & & & 8413 & 11705 \\
\hline $\operatorname{Tax}$ & & & & $8.25 \%$ & 273 & & & & & 278 \\
\hline sUBTo & & & & & 3650 & & & & 8413 & 12063 \\
\hline Tota & IL INOIRECT & & & $20.00 \%$ & 730 & & & $20.00 \%$ & 1683 & 2613 \\
\hline OVER & HEEAD & & & $8.70 \%$ & 381 & & & $8.70 \%$ & 878 & 1259 \\
\hline TOTAL & & & & & 4761 & 4451 & & & 10974 & 15735 \\
\hline
\end{tabular}


D D BLDG 3506, PARTIAL

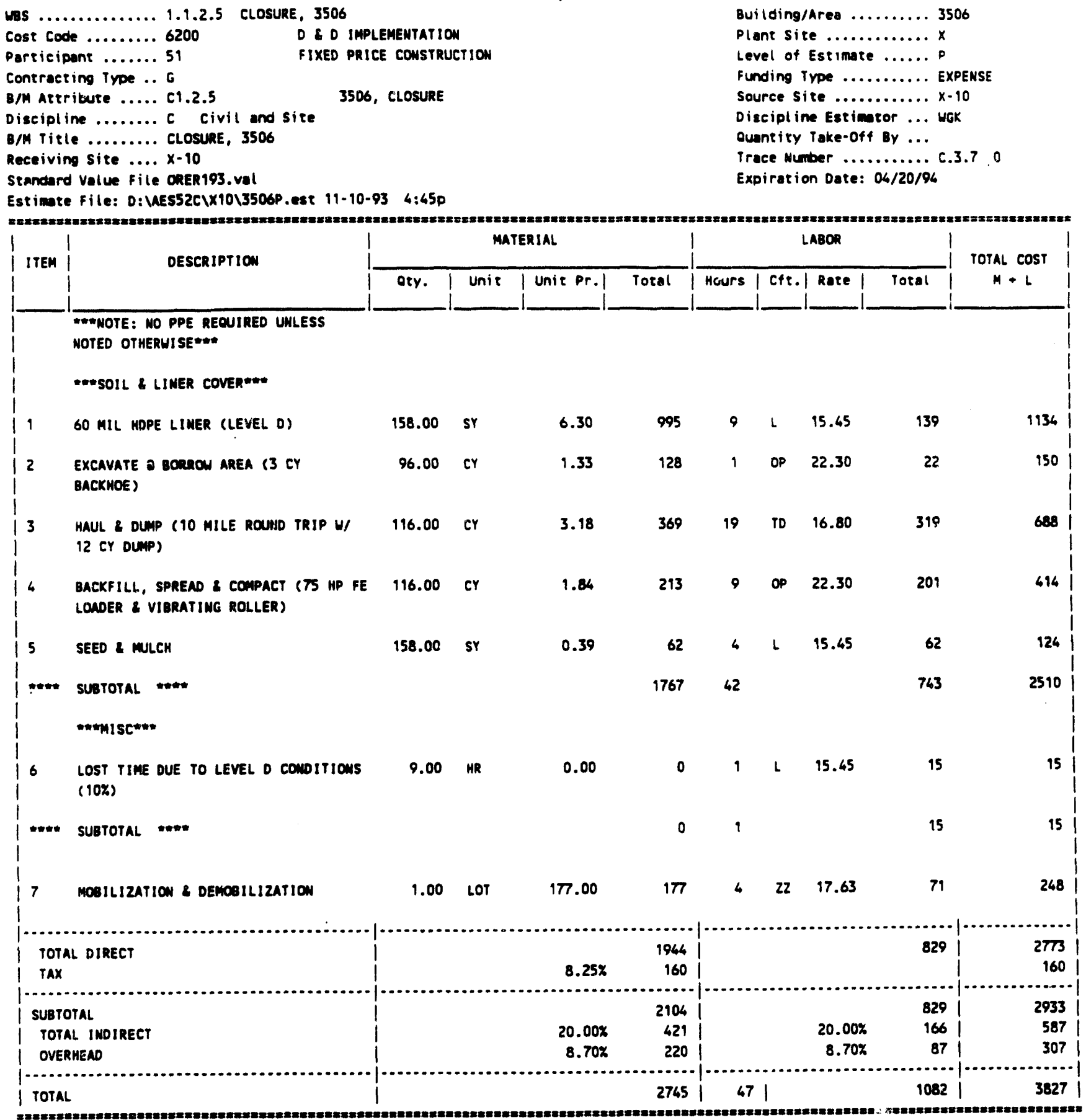


D I ELOG 3506, PARTIAL

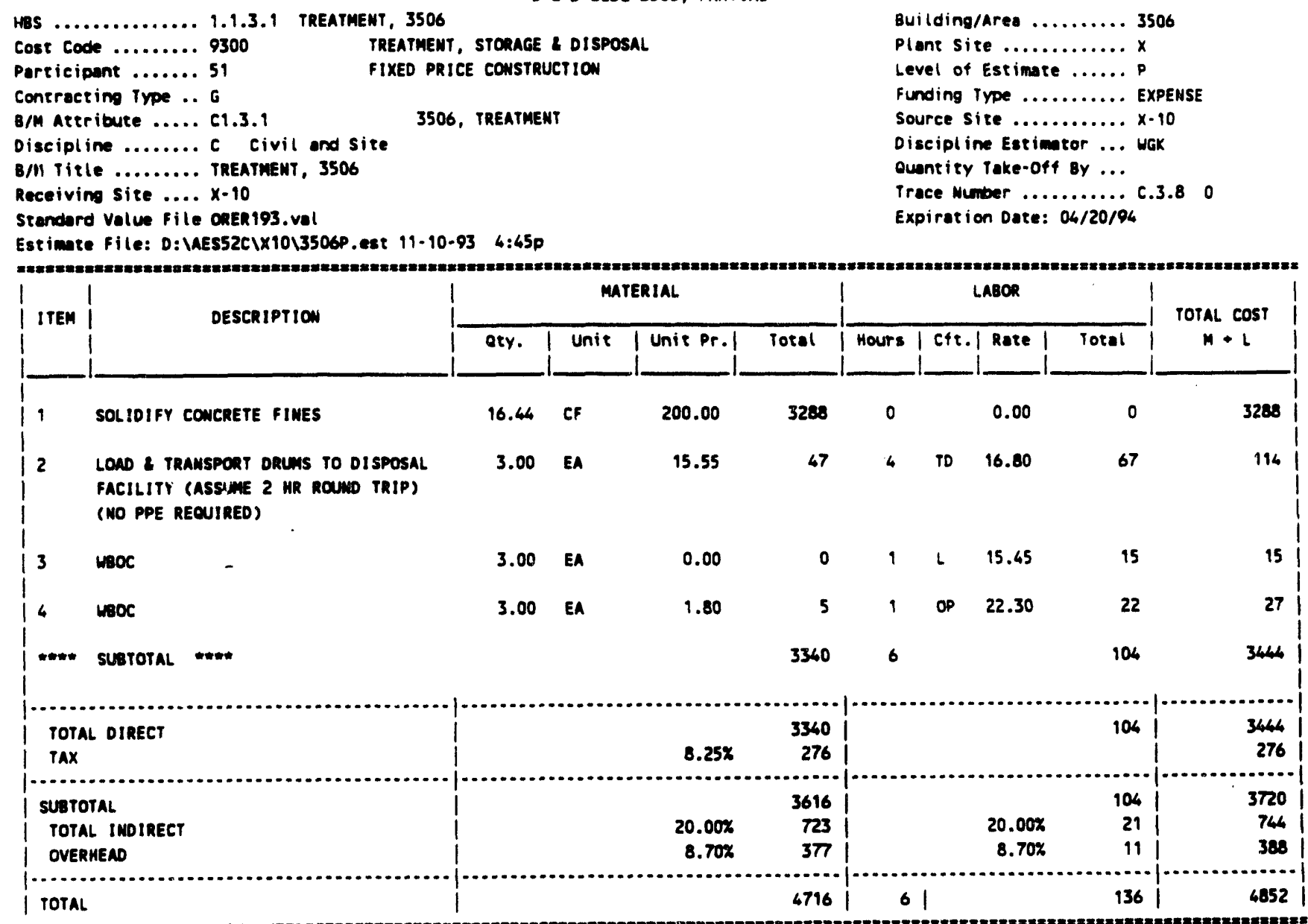


D 10 BLDG 3506, PARTIAL

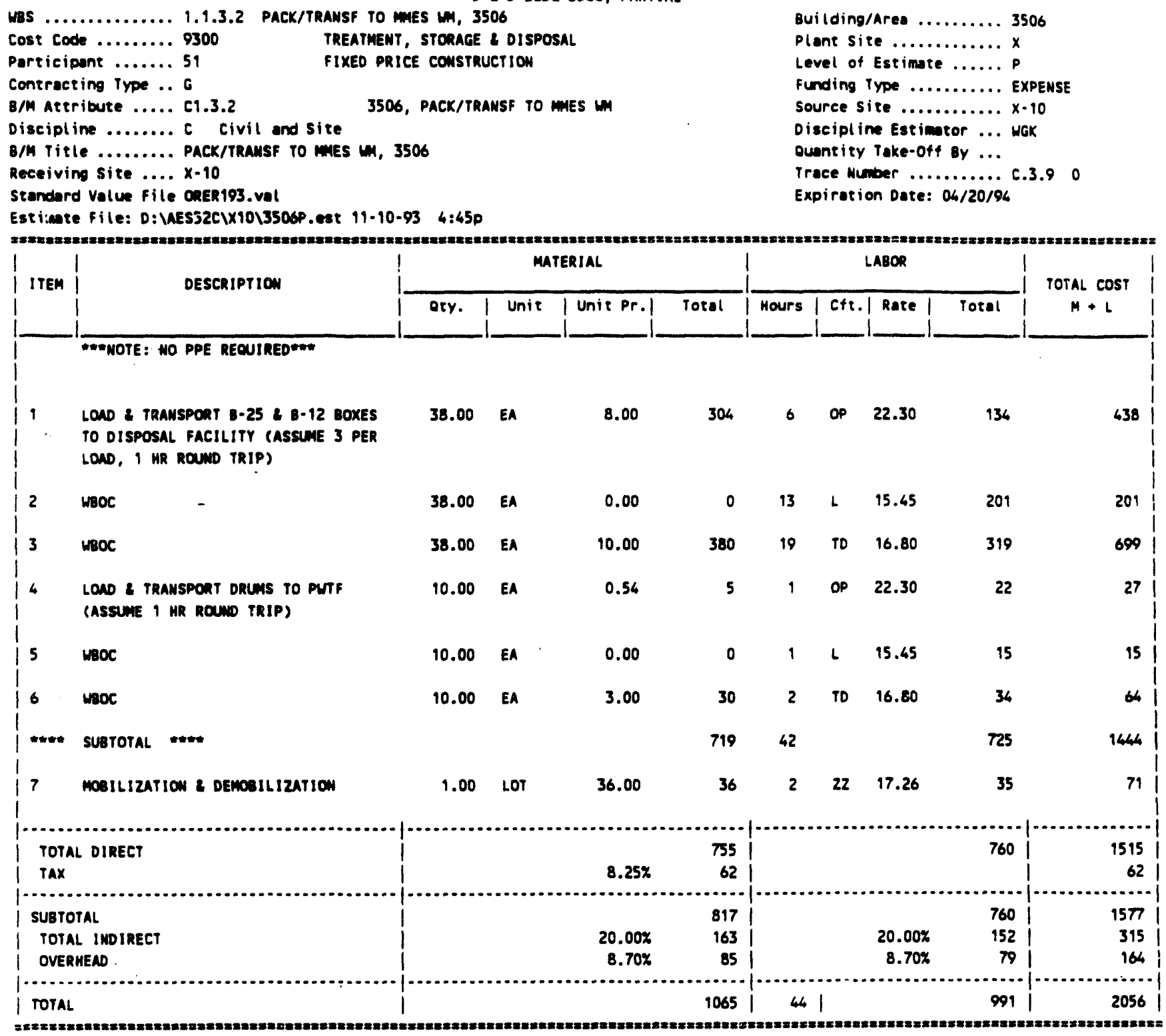


- 0 DLDG 3506, partial

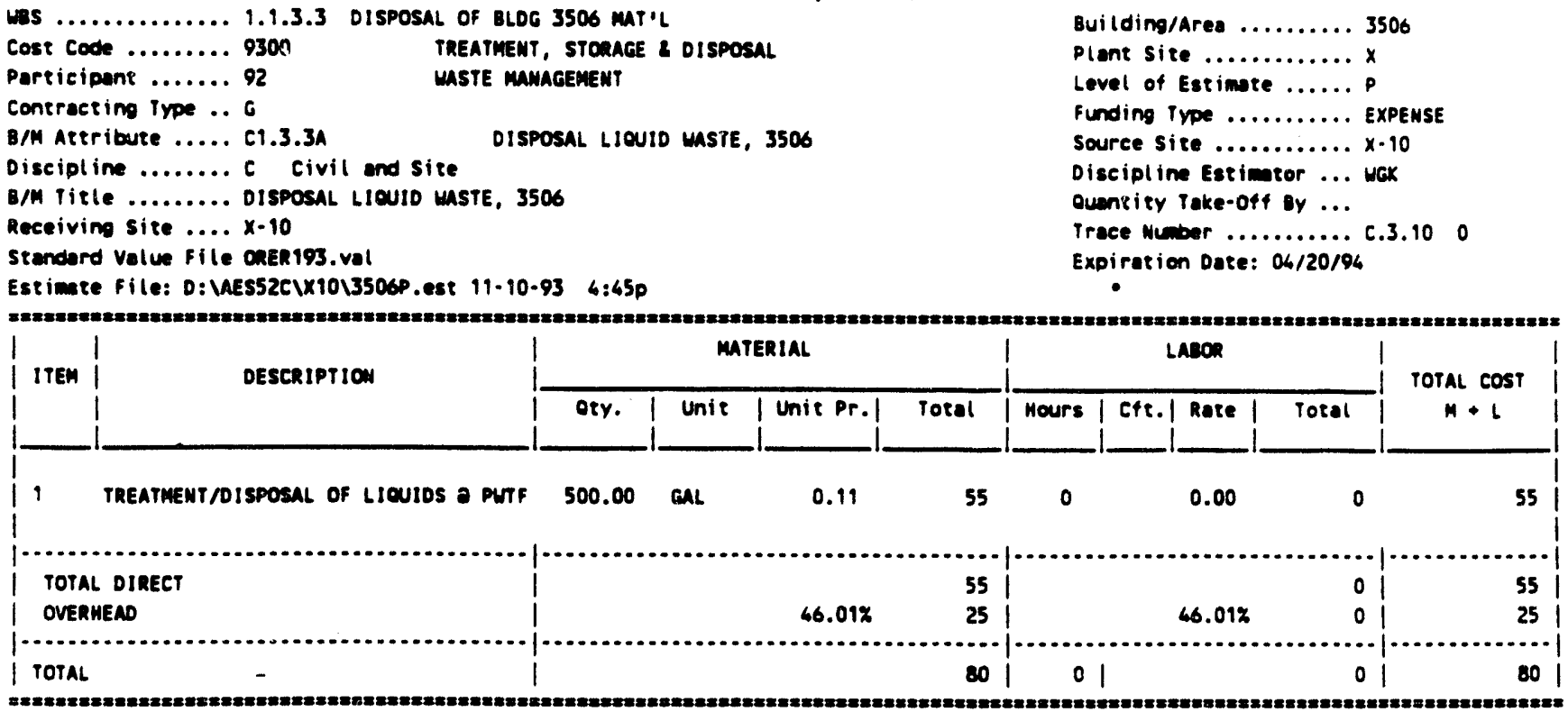


D 0 bldg 3506, partial

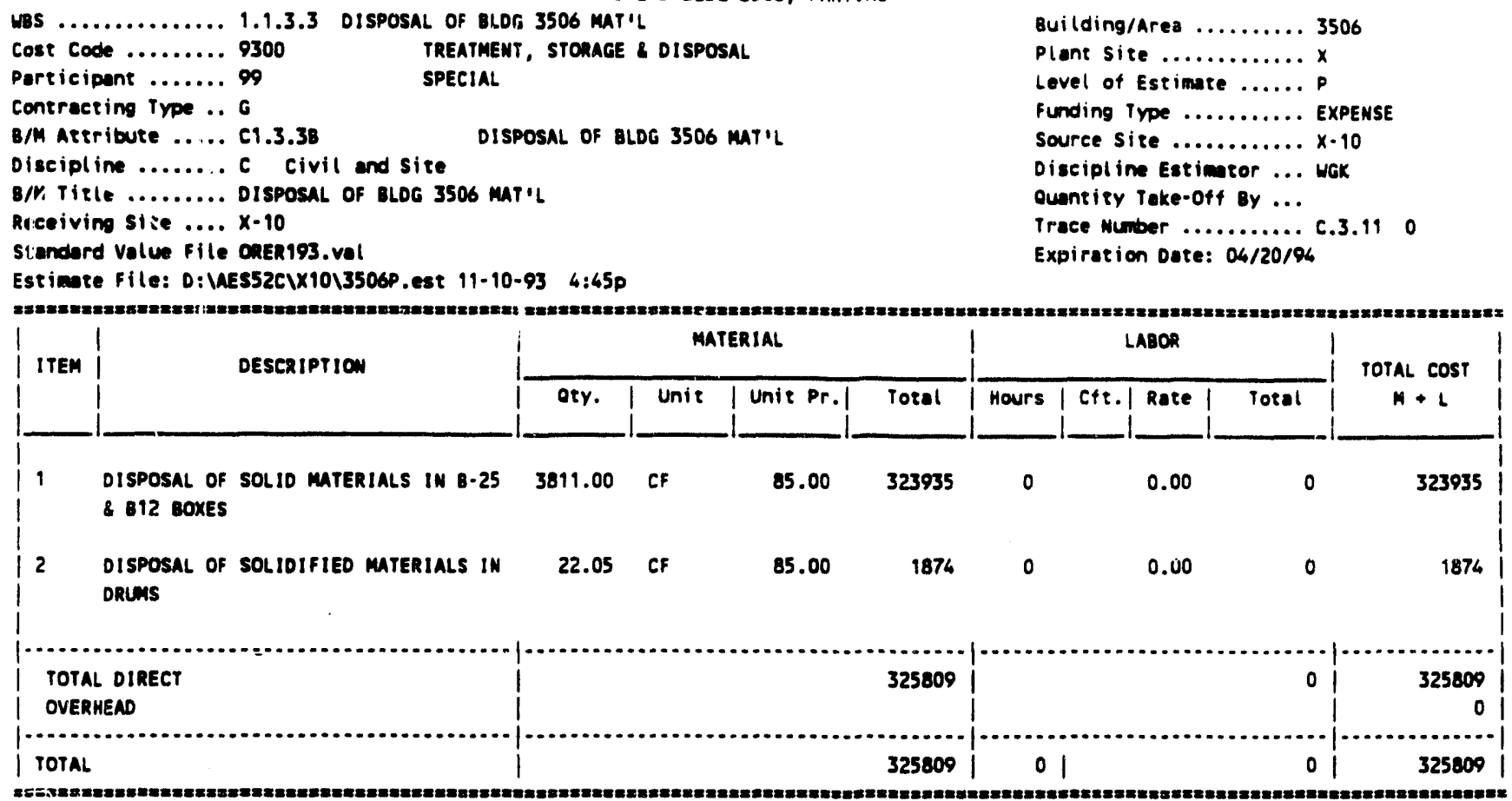




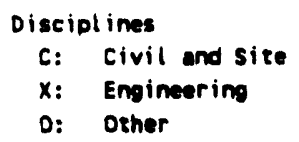

COST SUmuarY

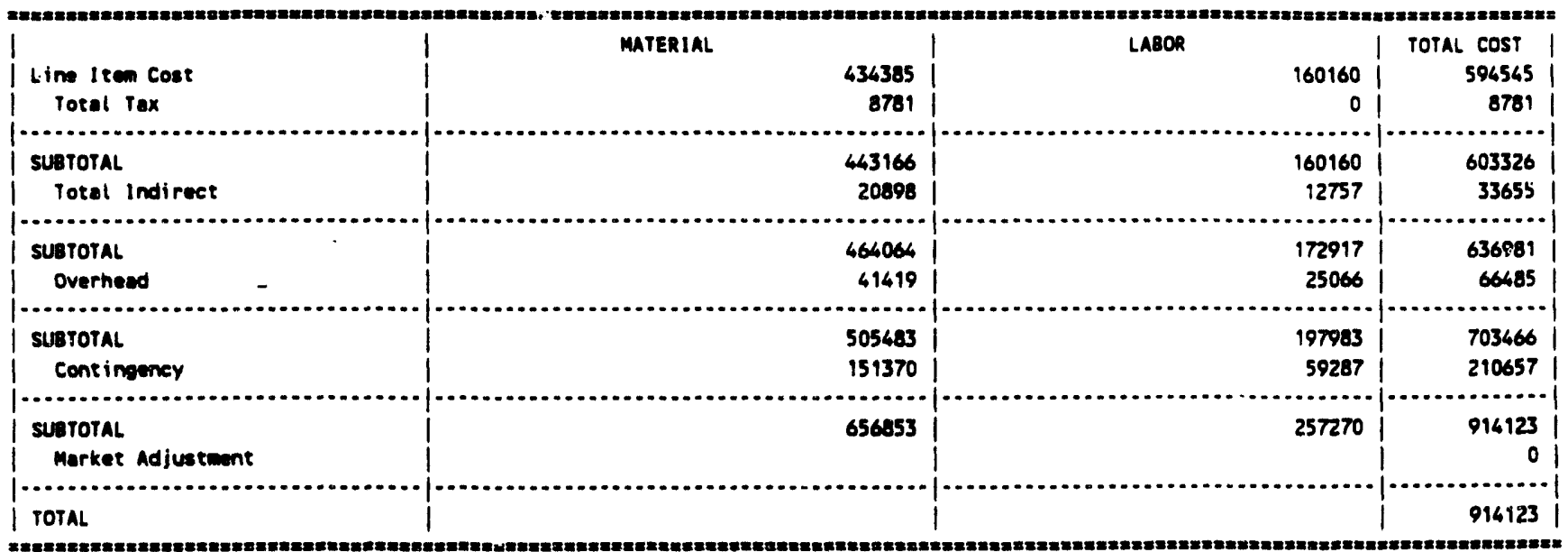


Appendix B.

Cost Estimate for

Complete Dismantlement of Building 3506 
SUMUAYY REPORT

Project Muber: 930031.1

D R D BLOG 3506

Project Eso Nuber.......

Revision Muber..........

Lest Update............11/10/93

Sort Order

1. wes

2. Participant

Approved by:

$\frac{\text { Leang Keneson }}{11-12-93}$

AES Version $5.2 \mathrm{c}$

Base fiscal Year/ouarter: $93 / 4$

STAMDARD VALUE: ORER193.val EXPIRES: $04 / 20 / 96$

ESTIMATE FILE: D: LAES52CIXIOU3506.est 11/10/93

SCMEDULE FILE: 3506

REPORT FILE : D: WAES52CIX10L35065. OUt 11/10/93 16:50:00 
$11 / 10 / 93$

Arranged By: was / Participent

\begin{tabular}{cccccc}
$\begin{array}{c}\text { Moterial } \\
s\end{array}$ & $\begin{array}{c}\text { Labor } \\
5\end{array}$ & $\begin{array}{c}\text { Total } \\
5\end{array}$ & $\begin{array}{c}\text { Moterial } \\
5\end{array}$ & $\begin{array}{c}\text { Labor } \\
5\end{array}$ & $\begin{array}{c}\text { Total } \\
s\end{array}$ \\
0 & 18 & 18 & 0 & 19 & 19 \\
1 & 21 & 22 & 1 & 21 & 22 \\
\hline 1 & 39 & 40 & 1 & 40 & 41
\end{tabular}

1.1.1.2 TITLE 1 \& II EMGIMEerimG, 3506 18 A-E TITLE 1 \& 11 ENeR.

48 mes $A-E$ SUPpont

total TITLE I \& II ENGINEERIMG, 3506

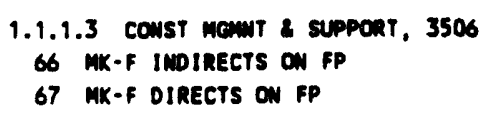

TOTAL CONST MENTI \& SUPPORT, 3506
1.1.1.4 TITLE III ENGINEERING, 3506
13 MES TITLE III EMER.
19 A-E TITLE III ENCR.

TOTAL TITLE III ENGIMEERING, 3506

\section{1 .2 BUILOING 3506 D \& 0 \\ 41 MUES FIELO MAINTENANCE \\ 51 FIXED PRICE COUSTRUCTION \\ TOTAL BUILOING 3506 D $\&$ D}

1.1.2.1 INITIAL CHARACTERIzATION, 3506 51 FIXED PRICE CONSTRUCTION

TOTAL INITIAL CHARACTERIZAIION, 3506

\begin{tabular}{rrrrrr}
0 & 24 & 24 & 0 & 24 & 26 \\
0 & 8 & 8 & 0 & 8 & 8 \\
\hline 0 & 32 & 32 & 0 & 32 & 32
\end{tabular}

\begin{tabular}{rrrrrr}
15 & 0 & 15 & 15 & 0 & 15 \\
0 & 32 & 32 & 0 & 32 & 32 \\
\hline 15 & 32 & 47 & 15 & 32 & 47
\end{tabular}

\begin{tabular}{rrrrrr}
2 & 27 & 29 & 2 & 28 & 30 \\
0 & 7 & 7 & 0 & 7 & 7 \\
\hline 2 & 34 & 36 & 2 & 35 & 37
\end{tabular}

\begin{tabular}{rrrrrr}
130 & 1 & 131 & 134 & 1 & 135 \\
33 & 36 & 69 & 36 & 37 & 71 \\
\hline 163 & 37 & 200 & 168 & 38 & 206
\end{tabular}

\begin{tabular}{llllll}
2 & 7 & 9 & 2 & 7 & 9 \\
\hline 2 & 7 & 9 & 2 & 7
\end{tabular}

B-4 
D $\angle$ OLDG 3506

SUmLARY REPORT

$s 1=\$ 1000$
$11 / 10 / 93$

Arrenged by: WS / Participant

1.1.2.2 EOUIPNENT REWOWAL, 3506 51 fixed paICE constnuction

TOTAL EOUIPMENT REMOVAL, 3506

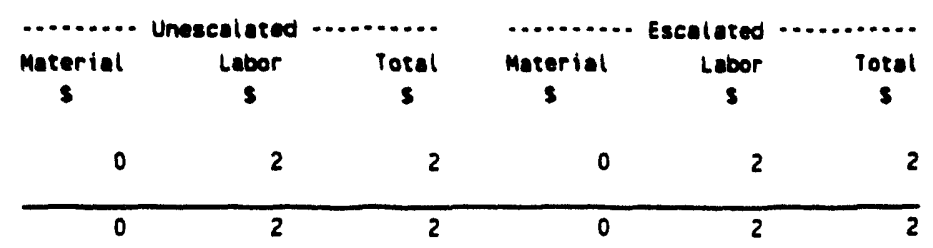

1.1.2.3 DECONTAMIMATION, 3506 51 FIXED PRICE COAstauction

TOTAL DECONTAMIMATION, 3506

\begin{tabular}{llllll}
0 & 0 & 0 & 0 & 0 & 0 \\
\hline 0 & 0 & 0 & 0 & 0 & 0
\end{tabular}

1.1.2.4 DISMAMTLE STRUCTURE, 3506

51 FIXED PRICE COAstRuction

\begin{tabular}{llllll}
9 & 15 & 24 & 9 & 16 & 25 \\
\hline 9 & 15 & 24 & 9 & 16 & 25
\end{tabular}

1.1.2.5 CLOSURE, 3506

51 FIXED PRICE CONSTRUCTION

TOTAL CLOSURE, 3506

\begin{tabular}{llllll}
3 & 1 & 4 & 3 & 1 & 4 \\
\hline 3 & 1 & 4 & 3 & 1 & 4
\end{tabular}

1.1.3.1 TREATMENT, 3506

51 FIXED PRICE COAstnuction

TOTAL TREATMENT, 3506

\begin{tabular}{llllll}
0 & 0 & 0 & 0 & 0 & 0 \\
\hline 0 & 0 & 0 & 0 & 0
\end{tabular}

1.1.3.2 PACK/TRANSF TO MUES IN, 3506 51 FIXED PRICE CONSTRUCTION

TOTAL PACK/TRAMSF to maEs IM, 3506

\begin{tabular}{llllll}
2 & 1 & 3 & 2 & 2 & 4 \\
\hline 2 & 1 & 3 & 2 & 2 & 4
\end{tabular}

1.1.3.3 DISPOSAL OF BLOG 3506 MAT'L 92 MASTE MANAGENENT

99 SPECIAL

TOTAL DISPOSAL OF BLDG 3506 MAT'L

\begin{tabular}{rrrrrr}
0 & 0 & 0 & 0 & 0 & 0 \\
639 & 0 & 639 & 657 & 0 & 657 \\
\hline 639 & 0 & 639 & 657 & 0 & 657
\end{tabular}


DE DLDS 3506

SUMURY REPORT

$\$ 1=\$ 1000$

$11 / 10 / 93$

Arranged Oy: ws / Perticipent

SUB - TOTAL

CONTINGENCY

\begin{tabular}{|c|c|c|c|c|c|}
\hline $\begin{array}{c}\text { Material } \\
\$\end{array}$ & $\begin{array}{c}\text { Labor } \\
\$\end{array}$ & $\begin{array}{c}\text { Total } \\
5\end{array}$ & $\begin{array}{c}\text { Material } \\
s\end{array}$ & $\begin{array}{c}\text { Labor } \\
3\end{array}$ & $\begin{array}{c}\text { Total } \\
3\end{array}$ \\
\hline 836 & 200 & 1036 & 859 & 205 & 1064 \\
\hline 251 & 60 & 311 & 258 & 62 & 320 \\
\hline 1087 & 260 & 1347 & 1117 & 267 & $\overline{1384}$ \\
\hline
\end{tabular}

GRANO TOTAL

B-6 
DETALL REPONT

Project Nuber: 930031.1

D 2 DLOG 3506

Project ESO Number......

Revision Numbr..........

Last Update.............11/10/93

Sort Order

1. 195

2. Porticipont

3. B/M Ateribute

Approved by:

Heankenesa $11-12.93$

Project Est/metor Date

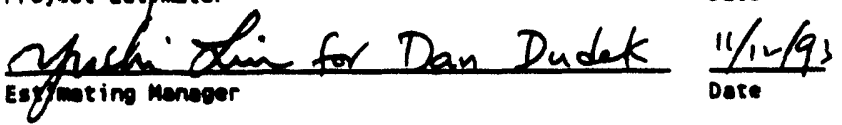

AES Version $5.2 c$

Buse Fiscal Year/ouprter: 93/4

STALDARD VALUE: ORER193.vol EXPIRES: 04/20/\%

ESTIMATE FILE: D: VAES52CIX1013506. Cat $11 / 10 / 93$

SCHEDULE FILE: 3506

REPORT FILE : D:VAES52CIX10135060.0UE 11/10/93 16:48:25 


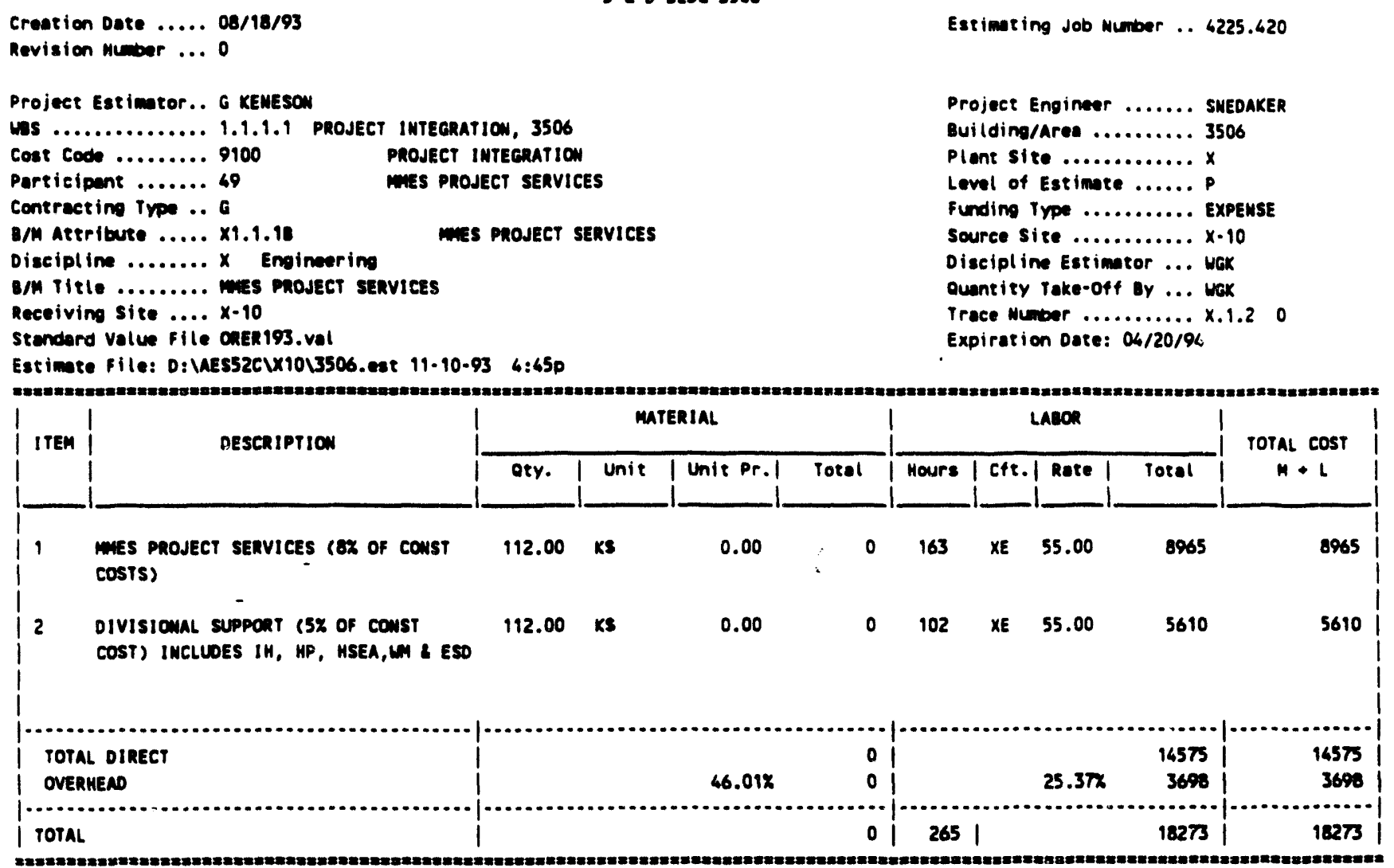



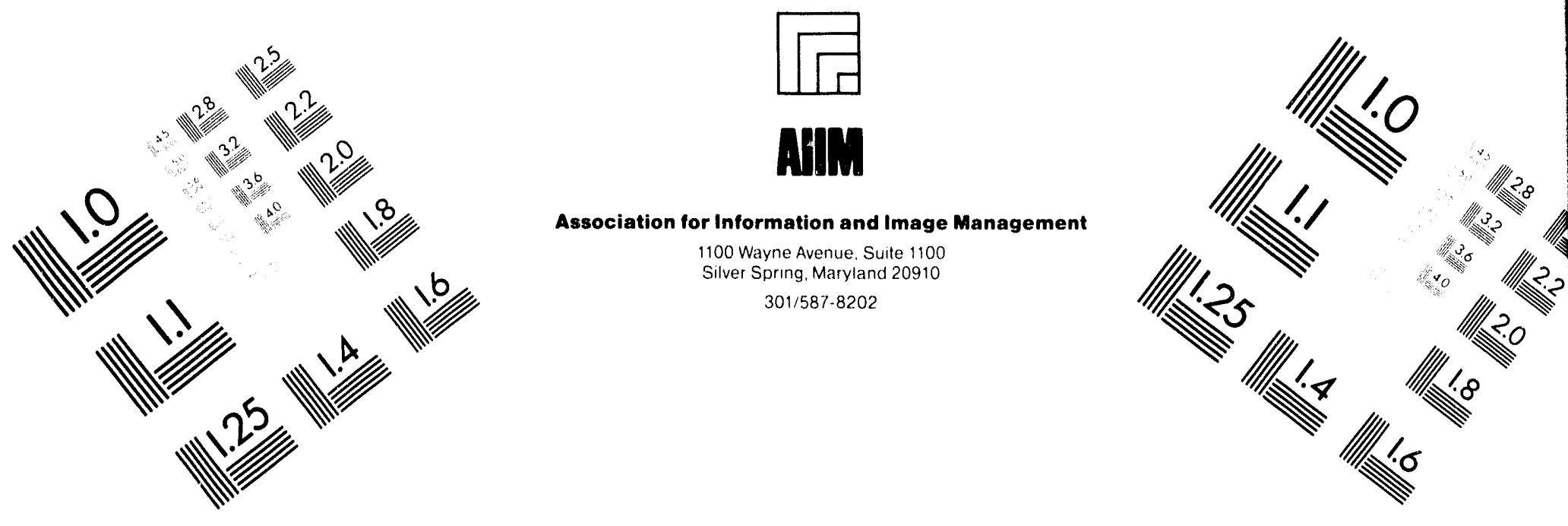

\section{Centimeter} 1m.

Inches

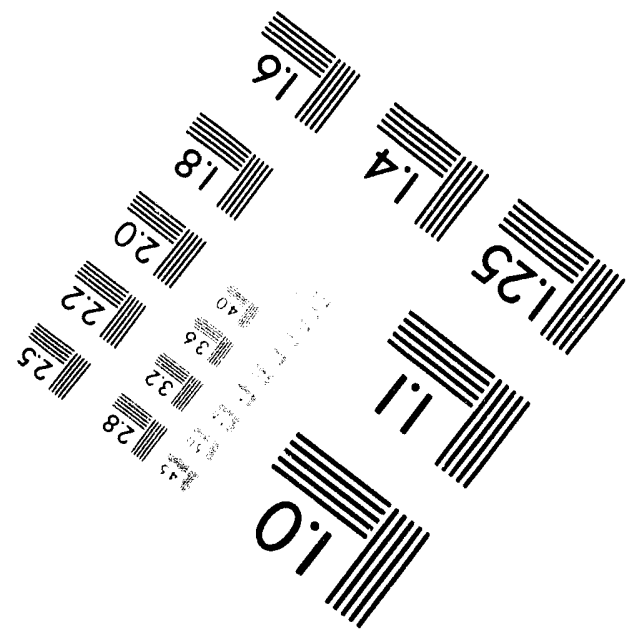

MANUFACTURED TO AIIM STANDARDS

BY APPLIED IMAGE, INC.

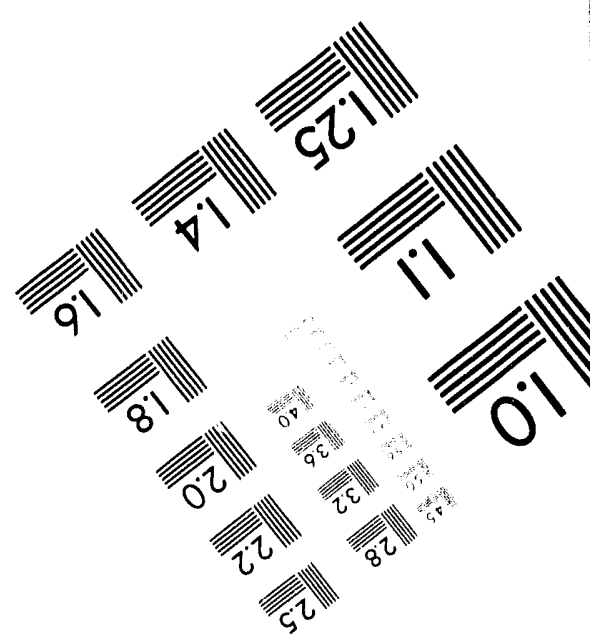



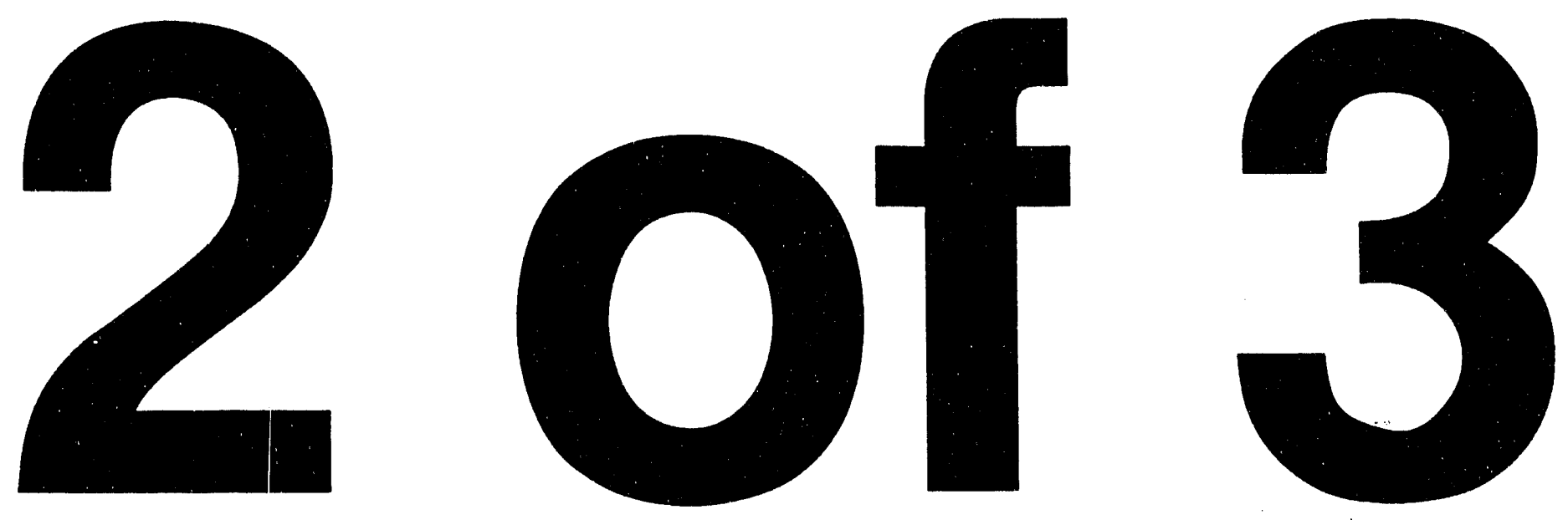


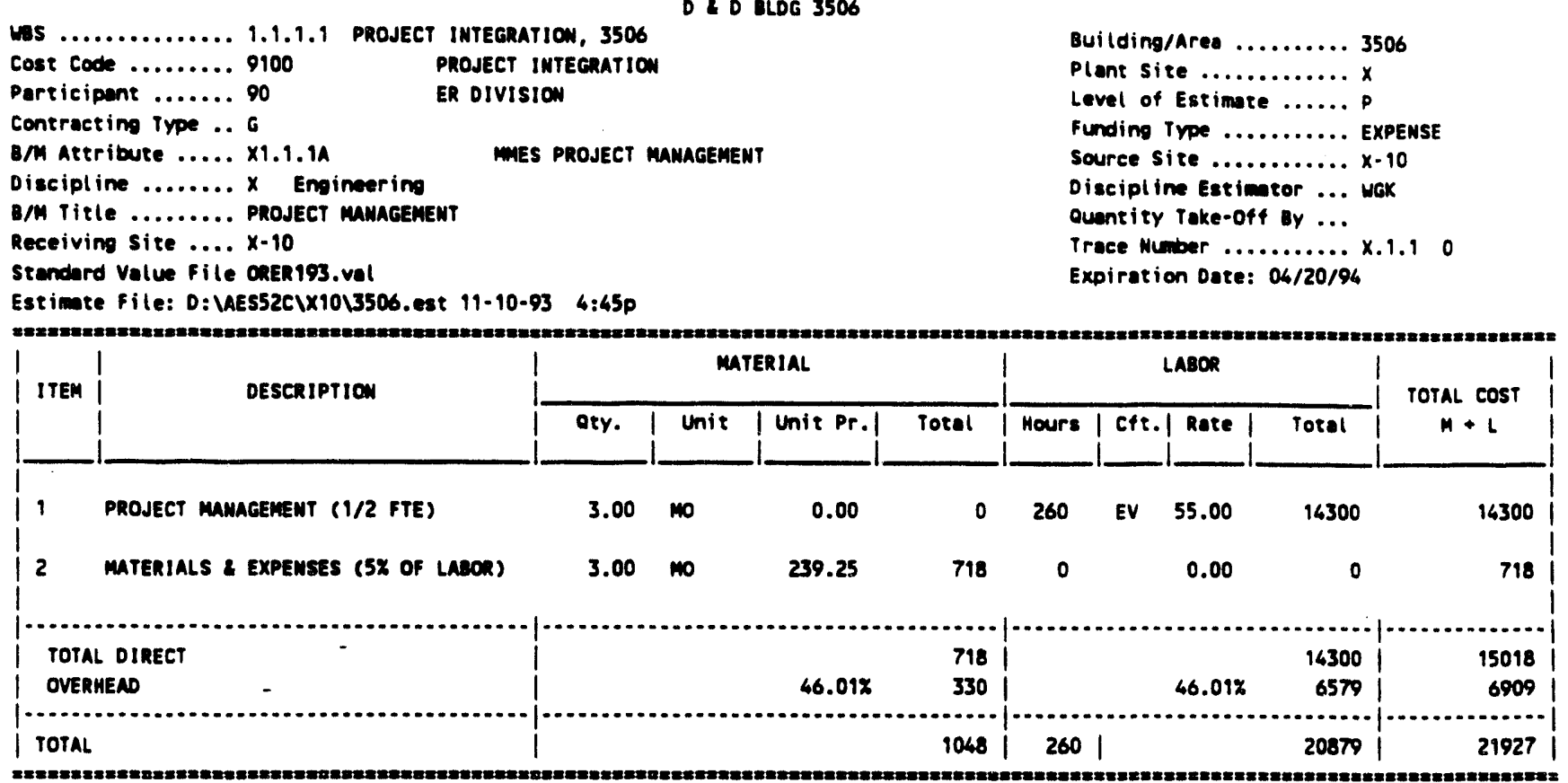


DE D BLDG 3506

WS $\ldots \ldots \ldots \ldots \ldots .1 .1 .1 .2$ TITLE 1 \& $\|$ II EMGIMEerimg, 3506

Cost coode ........ 5200

Participant ....... 18

Contracting Type .. $G$

B/M Attribute ...... $\times 1.1 .2 A$

DE D DESION

A-E TITLE I \& 11 ENGR.

Discipline ......... $\times$ Engineering

B/M Title .......... A-E TITLE I \& II

Receiving site .... $\times$ - 10

Standard value Fille ORERig3.val

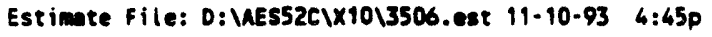

\begin{tabular}{|c|c|c|c|c|c|c|c|c|c|c|}
\hline \multirow{2}{*}{ ITEM } & \multirow{2}{*}{ DESCRIPTION } & \multicolumn{4}{|c|}{ MATERIAL } & \multicolumn{4}{|c|}{ LABOR } & \multirow{2}{*}{$\begin{array}{c}\text { TOTAL COST } \\
M+L\end{array}$} \\
\hline & & oty. & Unit & Unit Pr. I & Total & Hours & $c f t .1$ & Rate I & Total & \\
\hline 1 & $D \& D$ DESIGN & 1.00 & LS & 0.00 & 0 & 300 & ER & 80.00 & 24000 & $24000 i$ \\
\hline $\begin{array}{l}\text { TOTA } \\
\text { OVER }\end{array}$ & $\begin{array}{l}\text { DIRECT } \\
\text { IEAD }\end{array}$ & & & & 0 & & & & 24000 & $\begin{array}{r}24000 \\
0\end{array}$ \\
\hline TOTAL & - & & & & & 300 & . & & 24000 & 24000 \\
\hline
\end{tabular}

Building/areo ......... 3506

Plant site ..............

Level of Estimate ....... $p$

Funding Type ............ EXPENSE

Source site $\ldots \ldots \ldots \ldots \ldots \times 10$

Discipline Estimator ... WGK

Quntity Take-Off By ... WGK

Expiration Date: $04 / 20 / 94$
Trace Number ........... $\times .1 .30$ 
DE D BLDG 3506

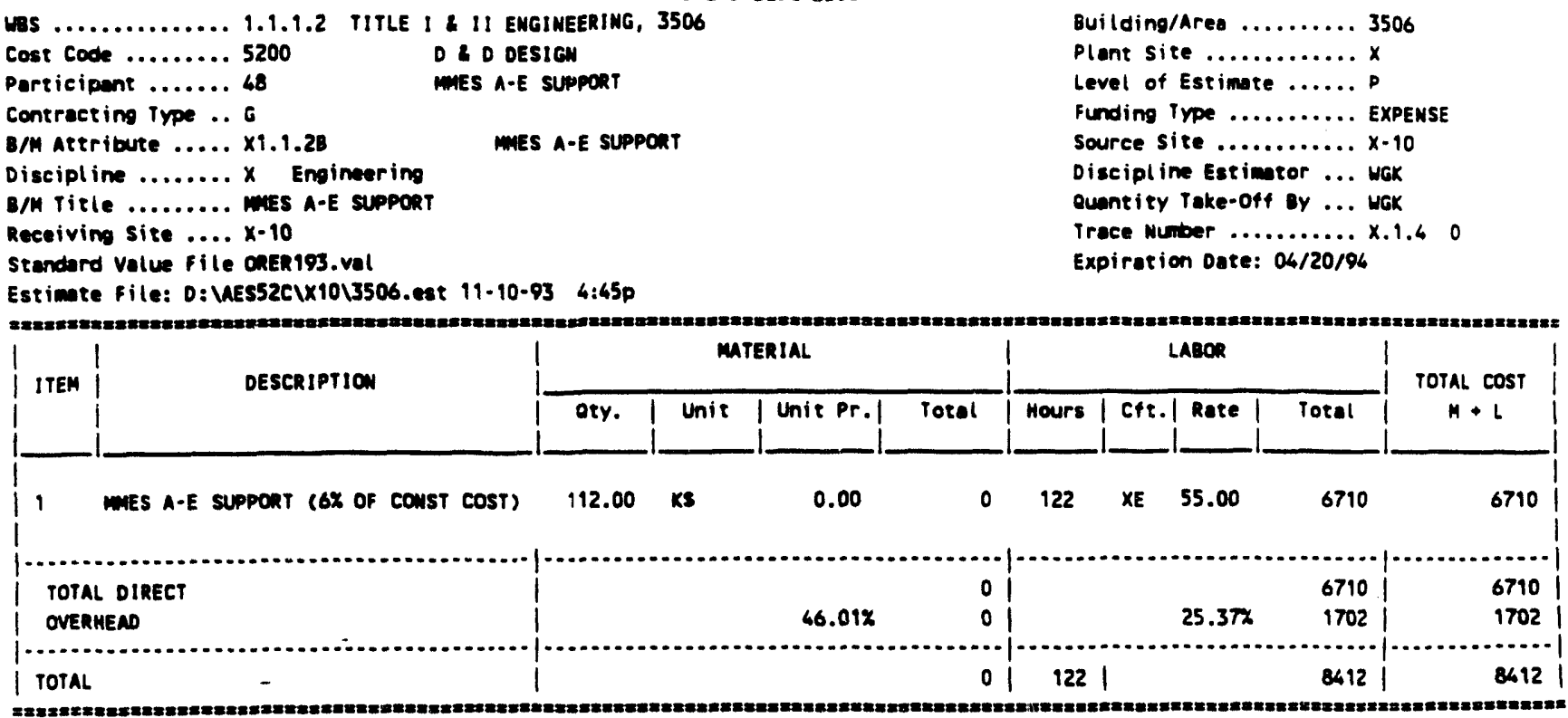


D L D BLD 3506

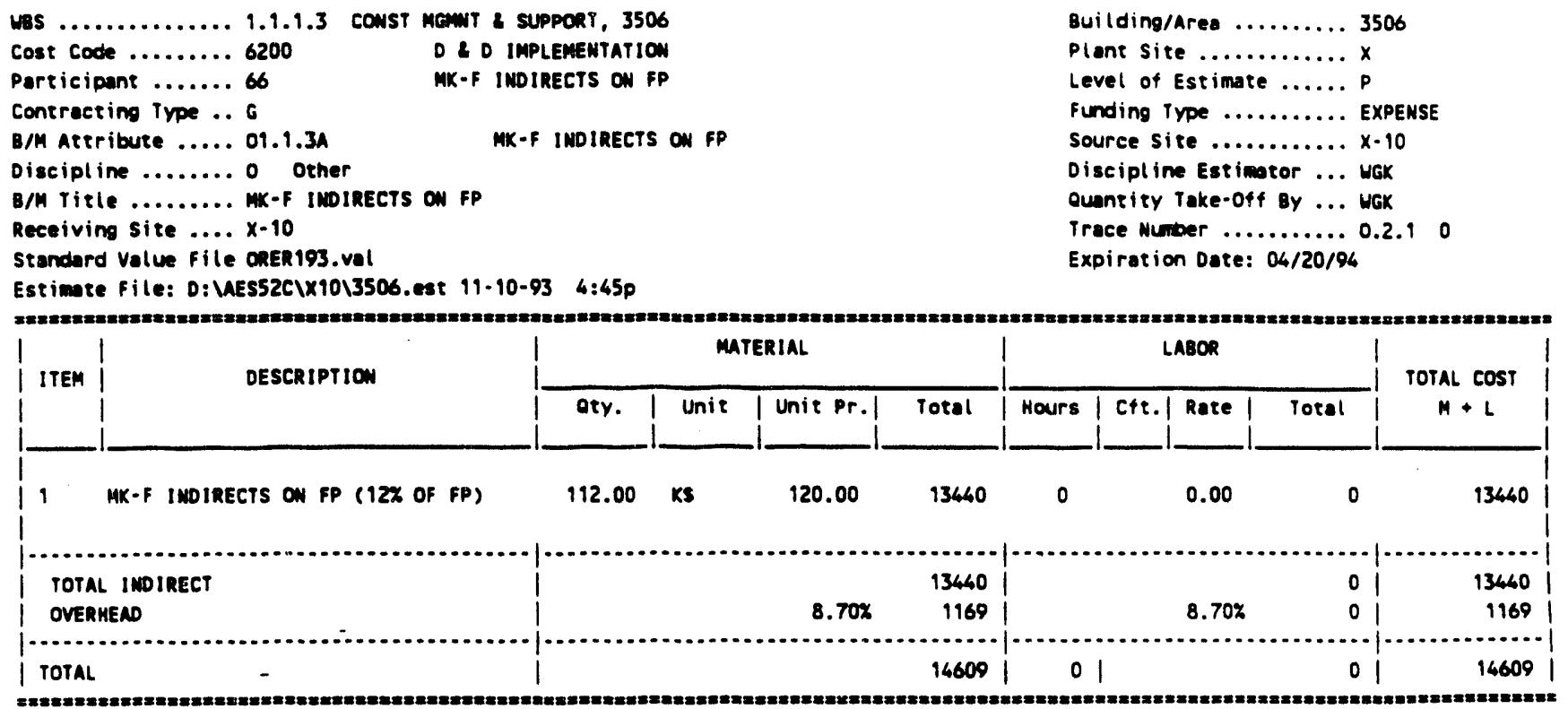

\section{B-12}


D D BLDG 3506

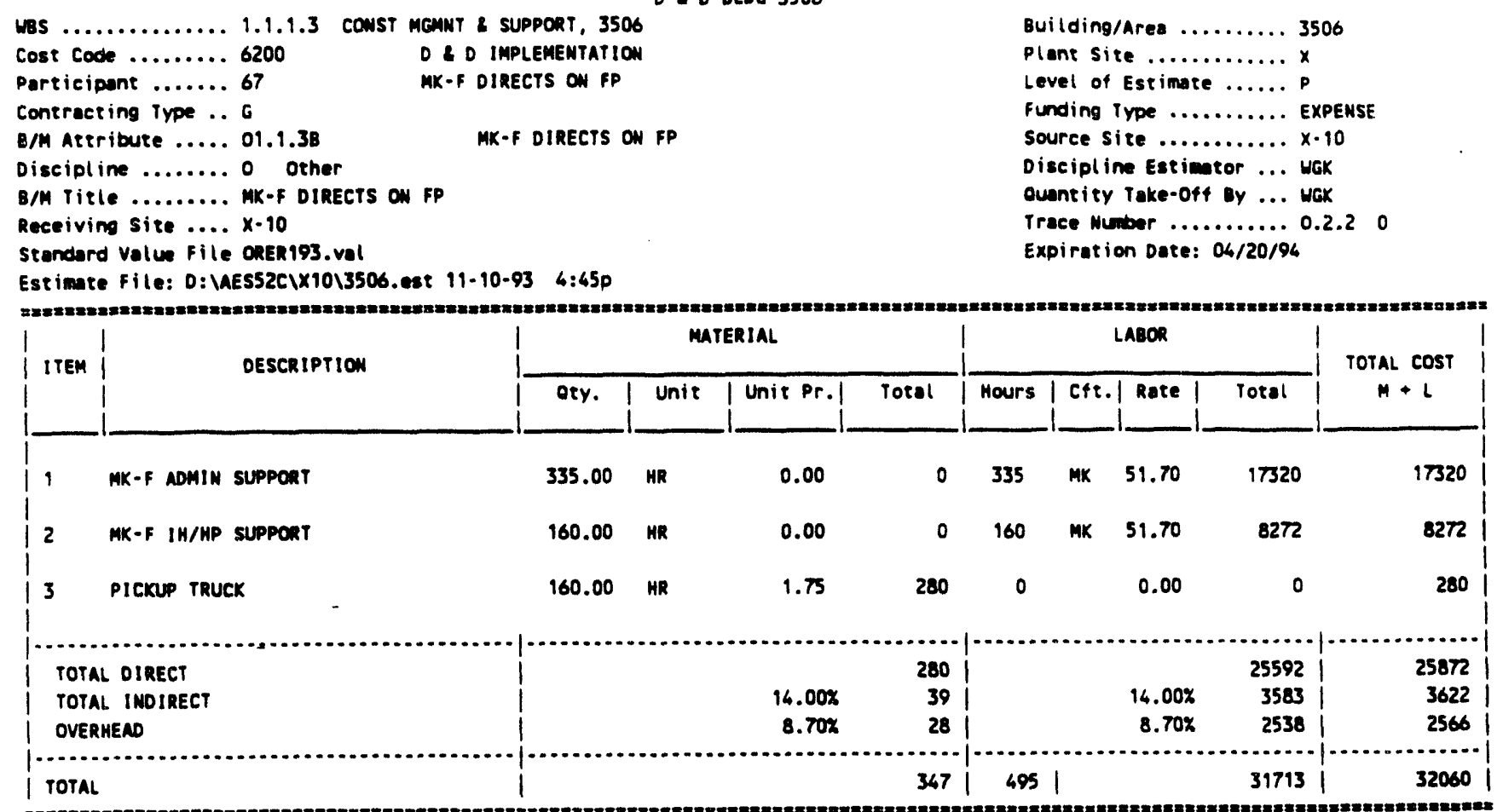


D \& D BLDG 3506

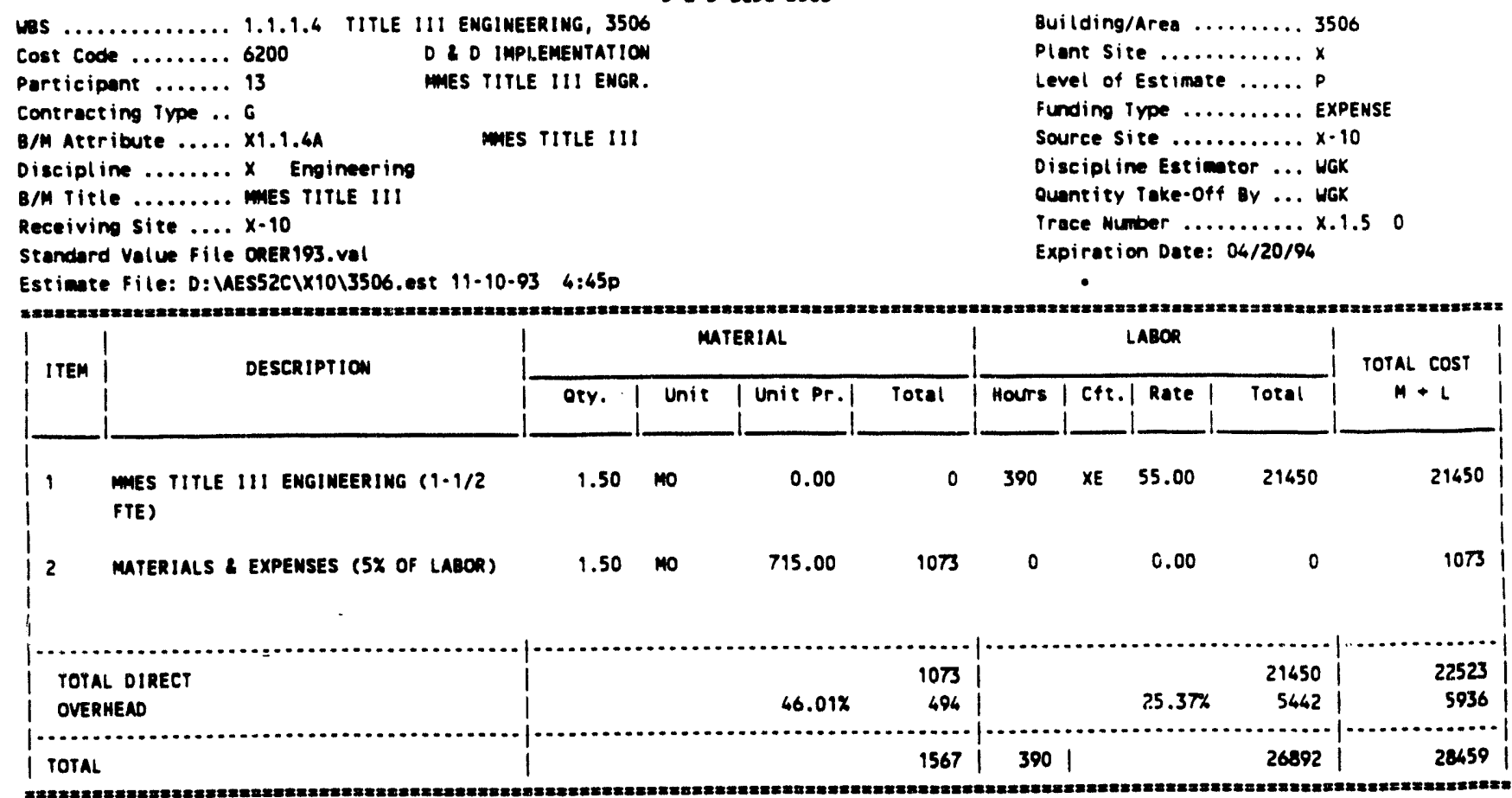


MBS $. . . \ldots \ldots \ldots \ldots . .1 .1 .1 .4$ TITLE 111 ENGIMEERING, 3506

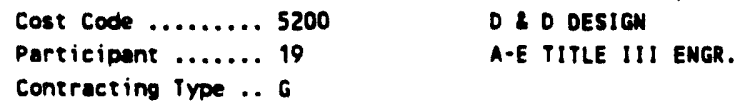

| DESCRIPTION

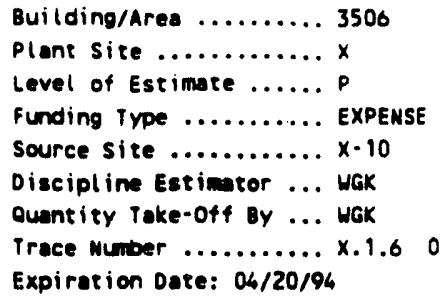


D \& BLDG 3506

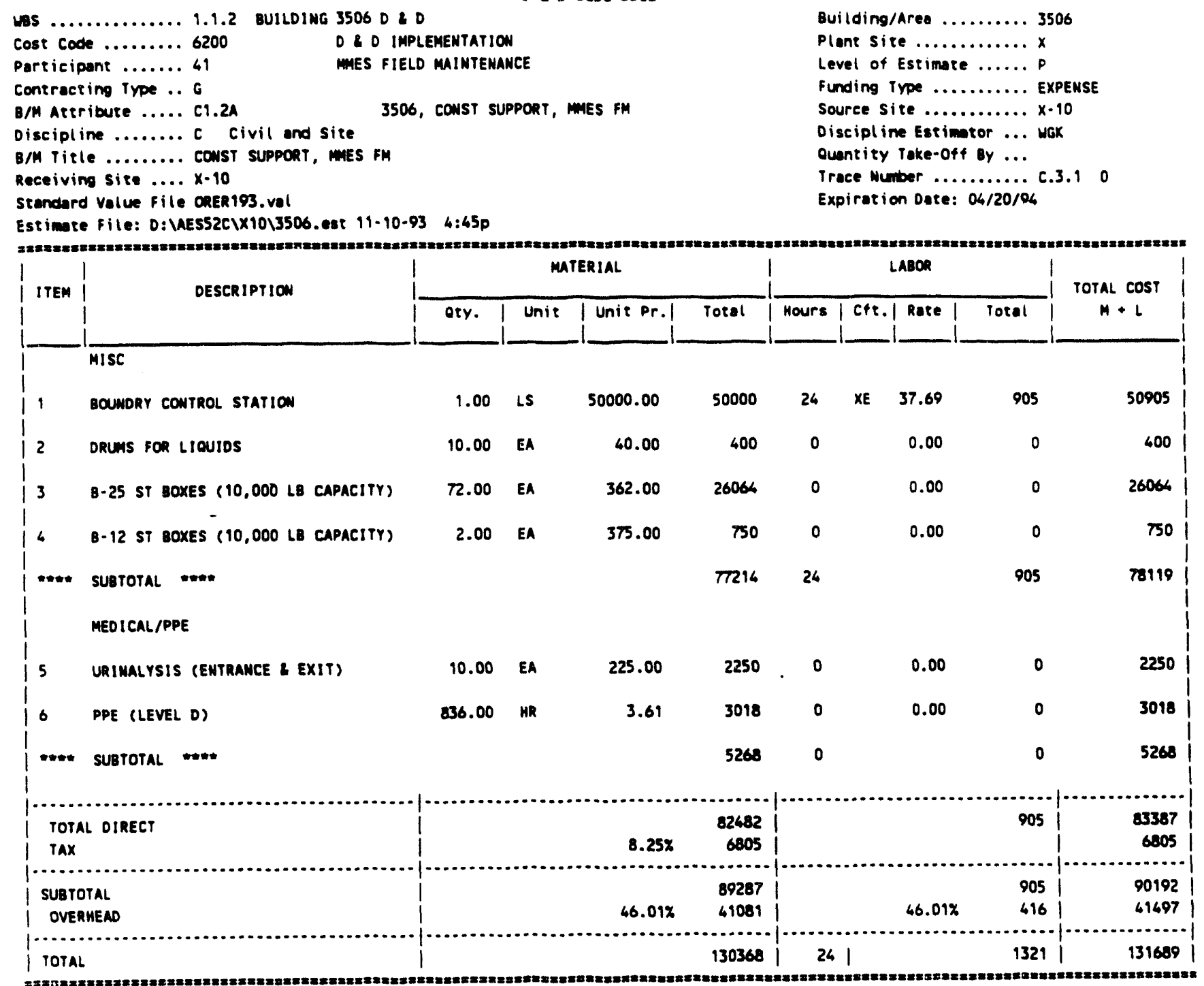




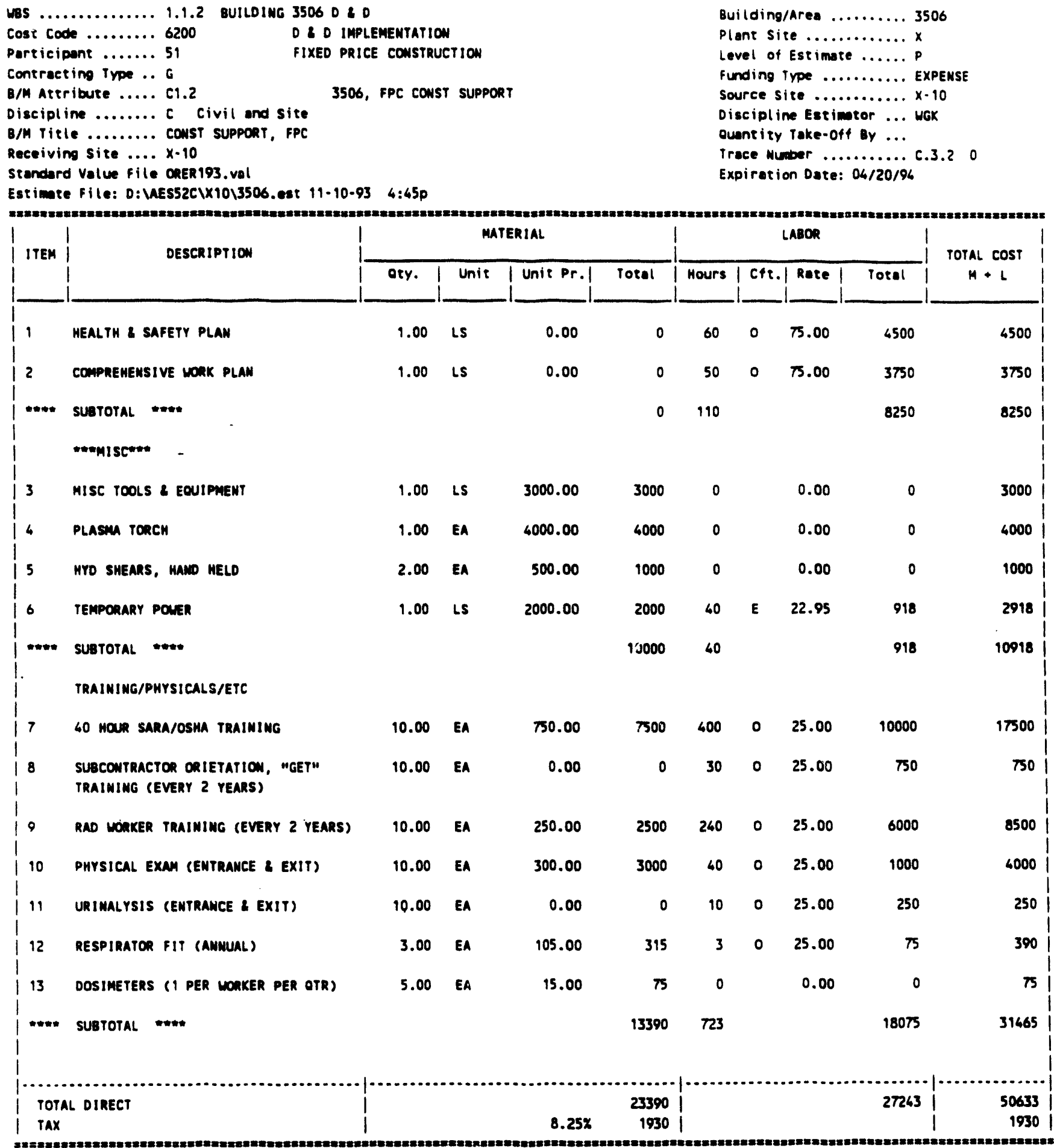


D \& D BLOG 3506

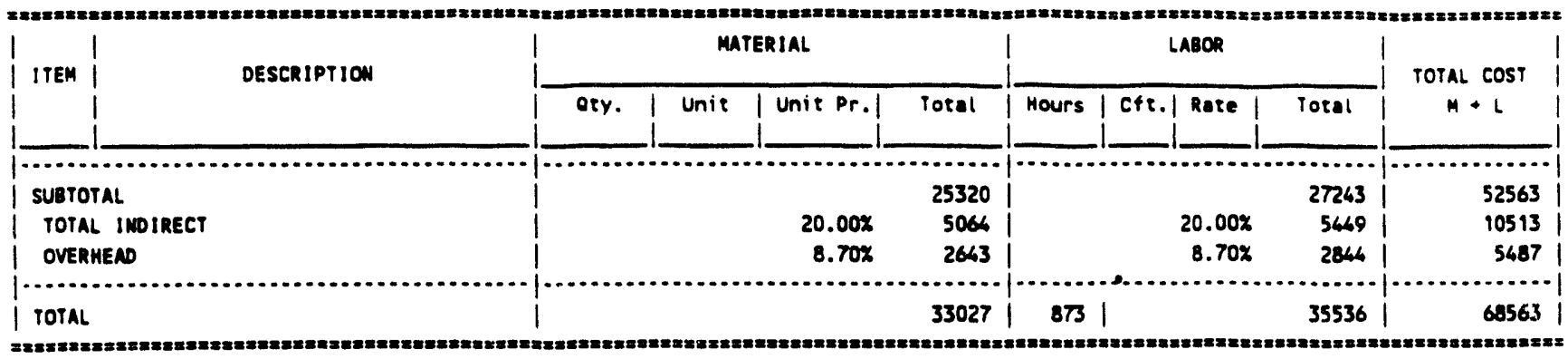


$\begin{array}{ll}\text { Cost Code } \ldots \ldots \ldots .6200 & \text { D \& D IMPLEMENTATION } \\ \text { Participant } \ldots \ldots \ldots .51 & \text { FIXED PRICE CONSTRUCTION }\end{array}$

2. BLDG 3506

Coneracting Type ... $\mathrm{C}$

B/M Attribute ..... C1.2.1

3506, INITIAL CHARACTERIZATION

Discipline ......... c Civil and site

B/A Title ......... IMITIAL CHARACTERIzatION, 3506

Receiving site ..... $x-10$

Standard Value File OnER193.vel

Estimate File: D: \AES52C1X1013506.est 11-10-93 4:45p

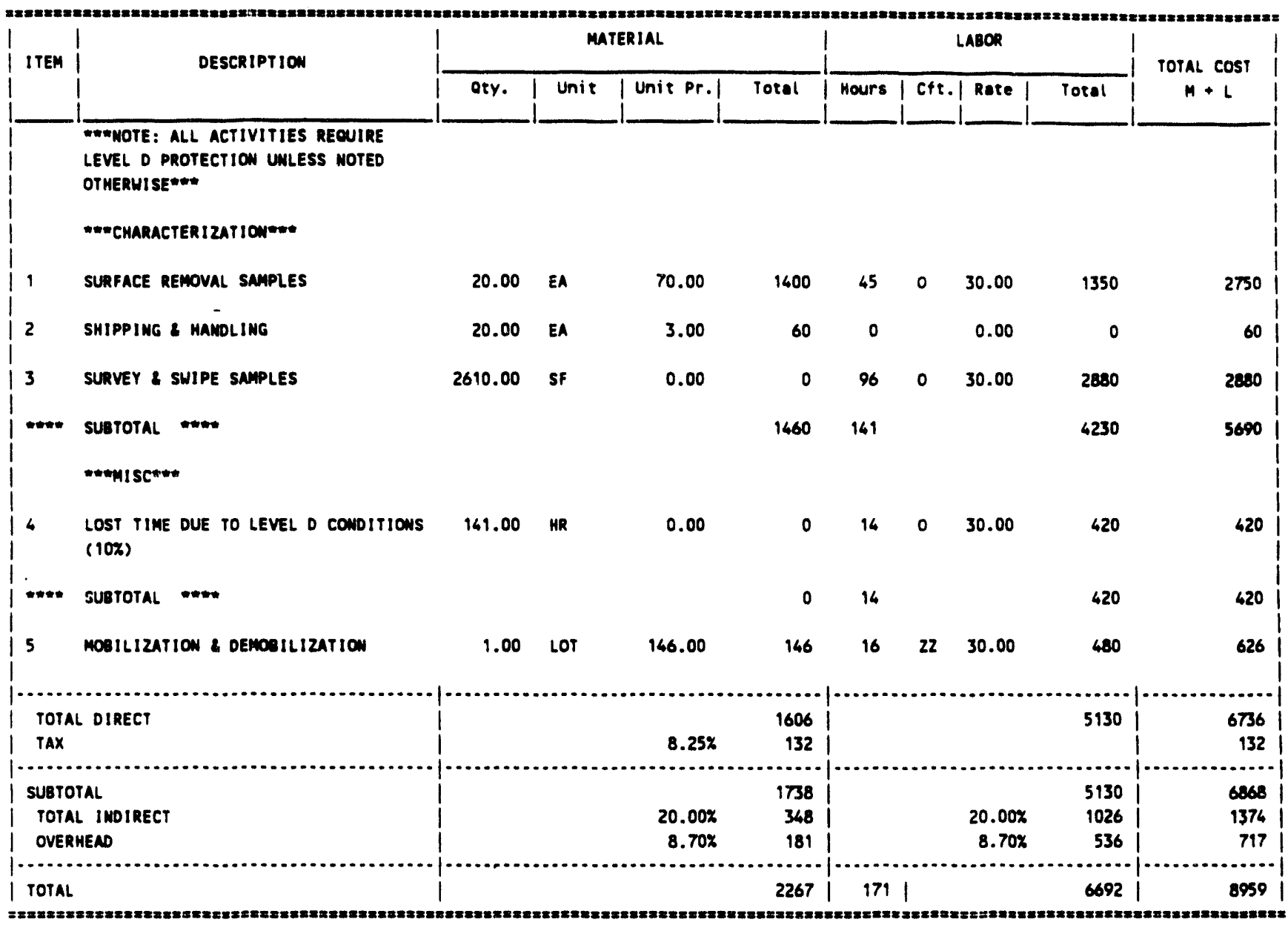

Building/Area ......... 3506

Plant site .............

Level of Estimate ....... $p$

Funding type .......... Expense

Source site ............ $x-10$

Discipline Estimator ... WGK

Quantity Take-off By ...

Trace Number .............. C.3.3 0

Expiration Date: $04 / 20 / 94$ 


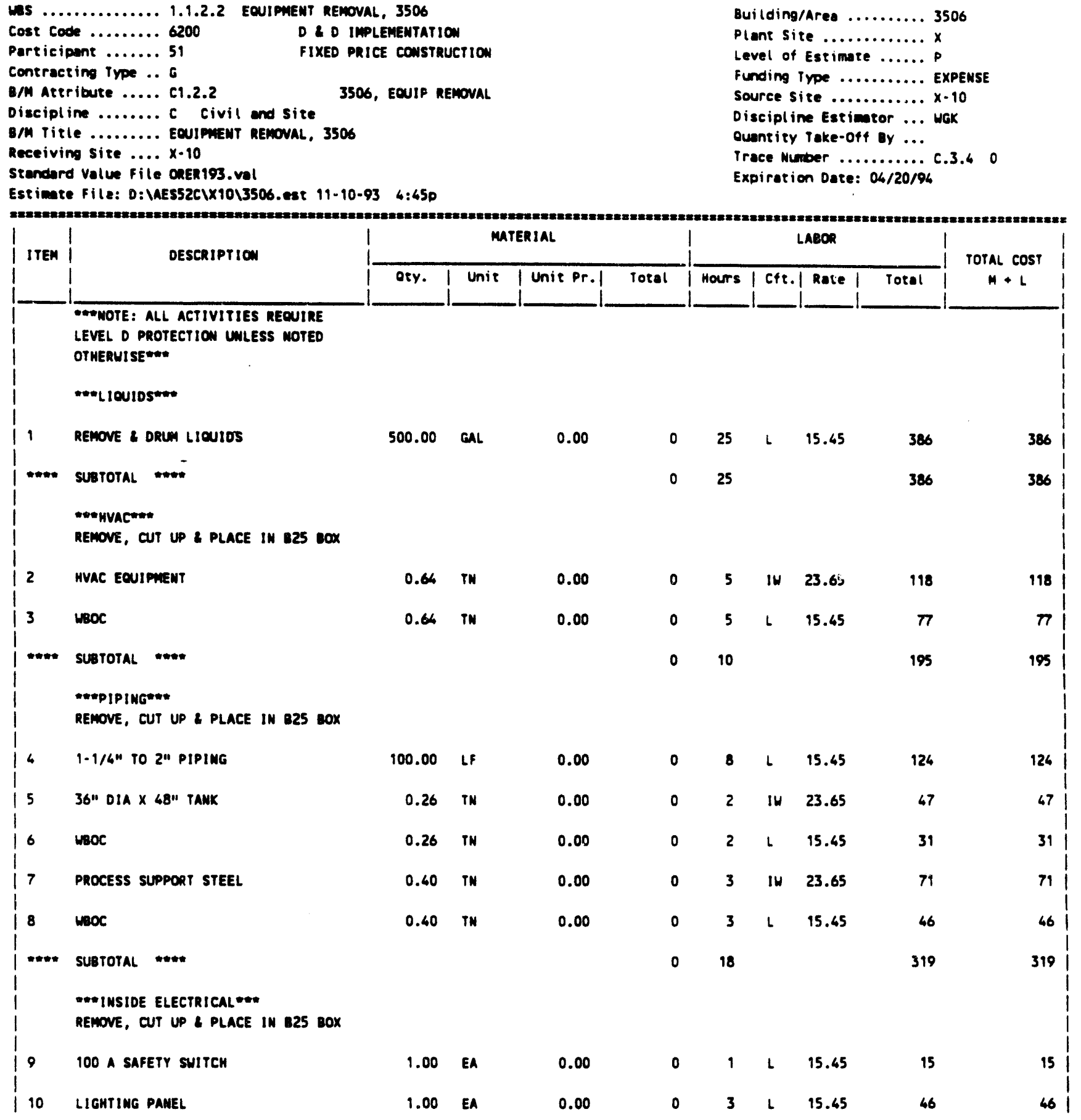


D 20 BLOG 3506

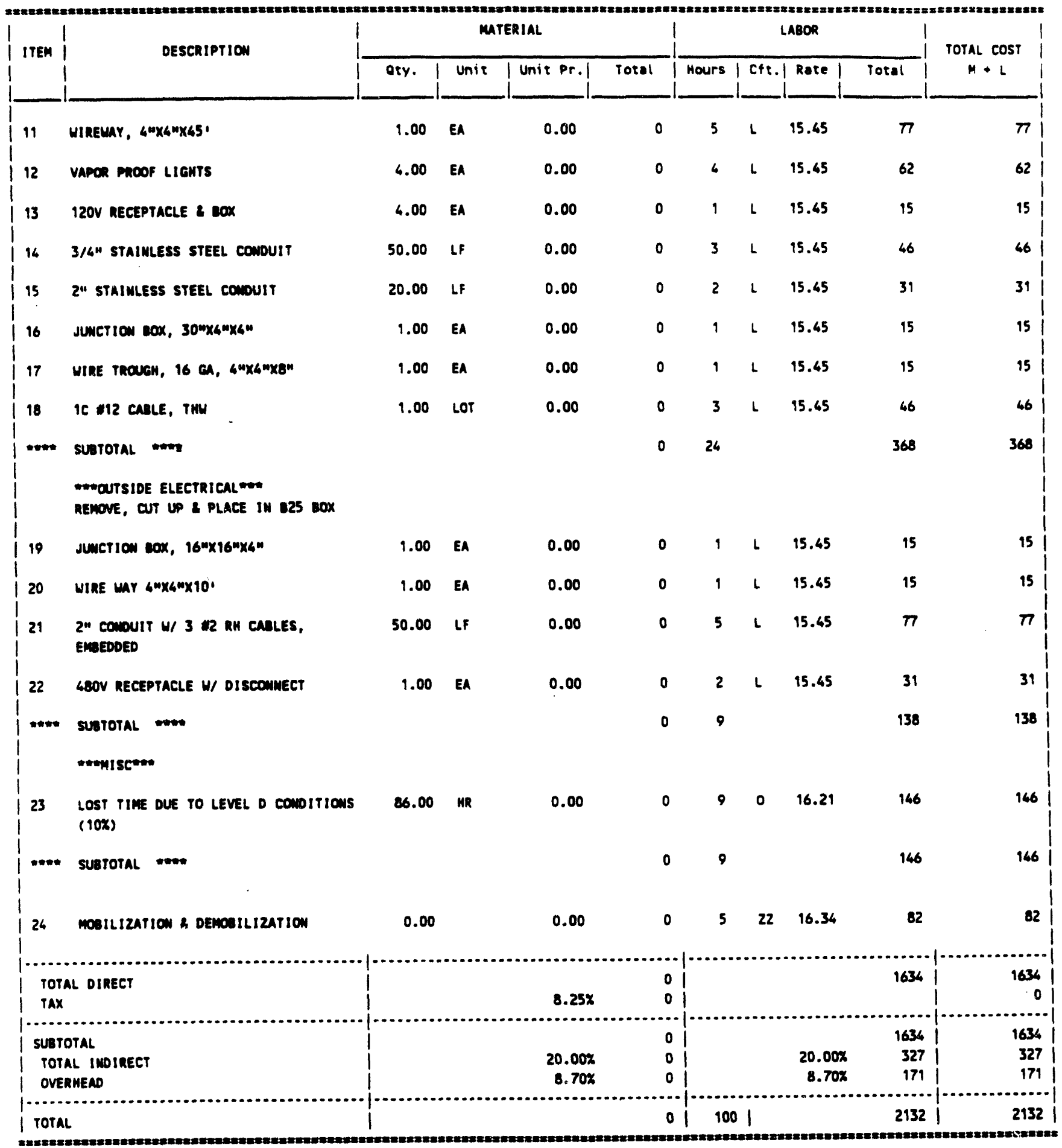


D 2 D BLDG 3506

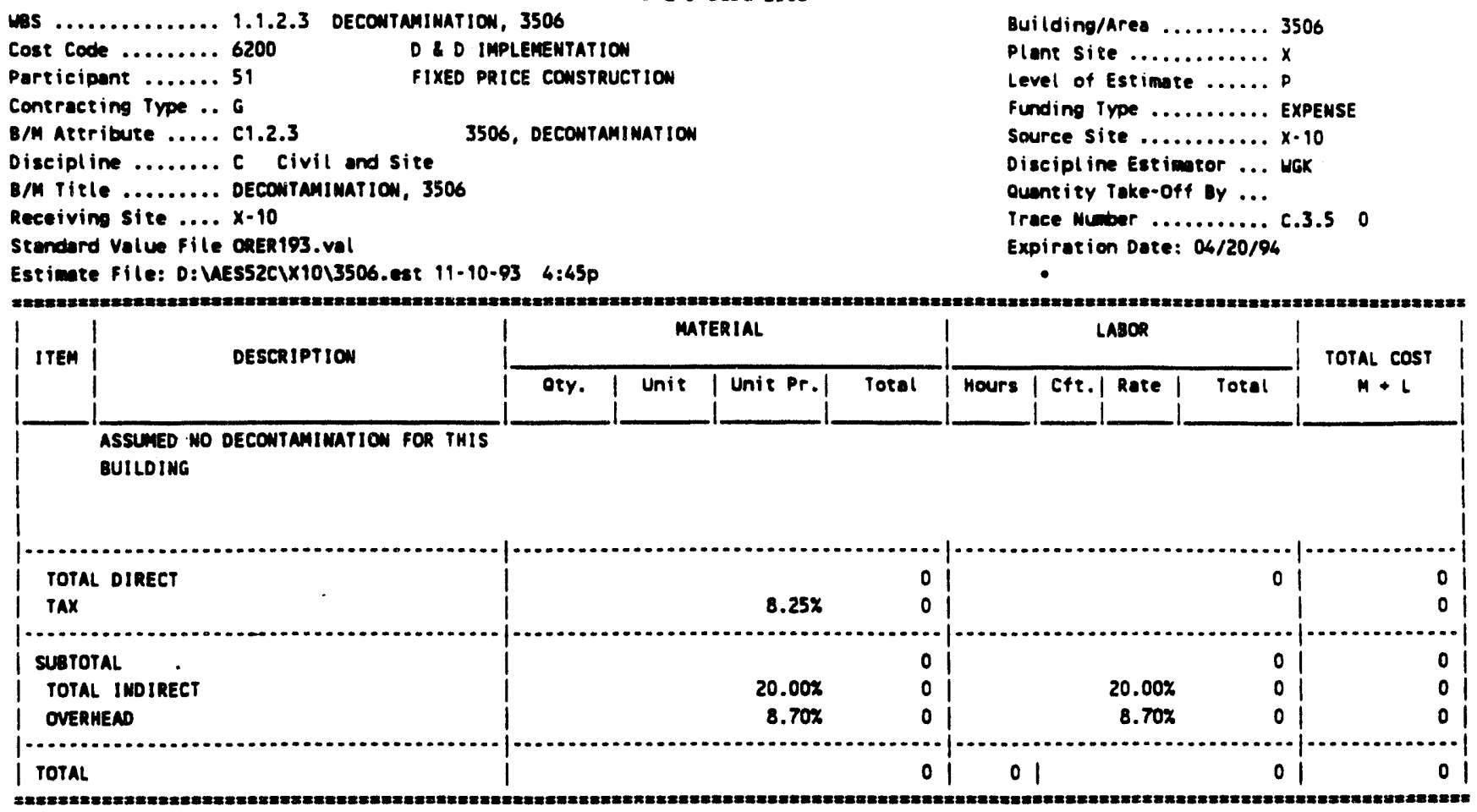


D \& D BLDG 3506

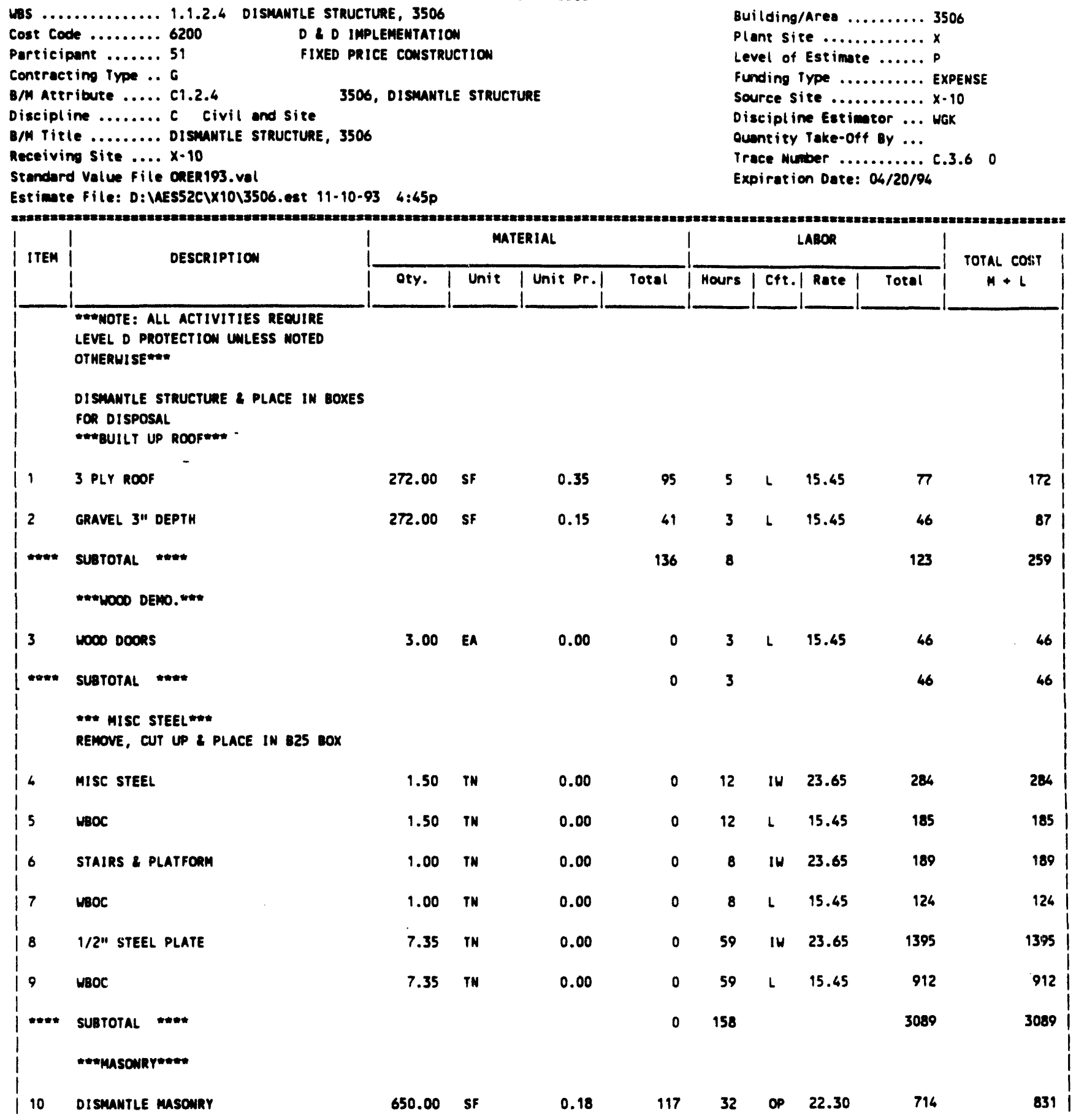


D ID BLDG 3506

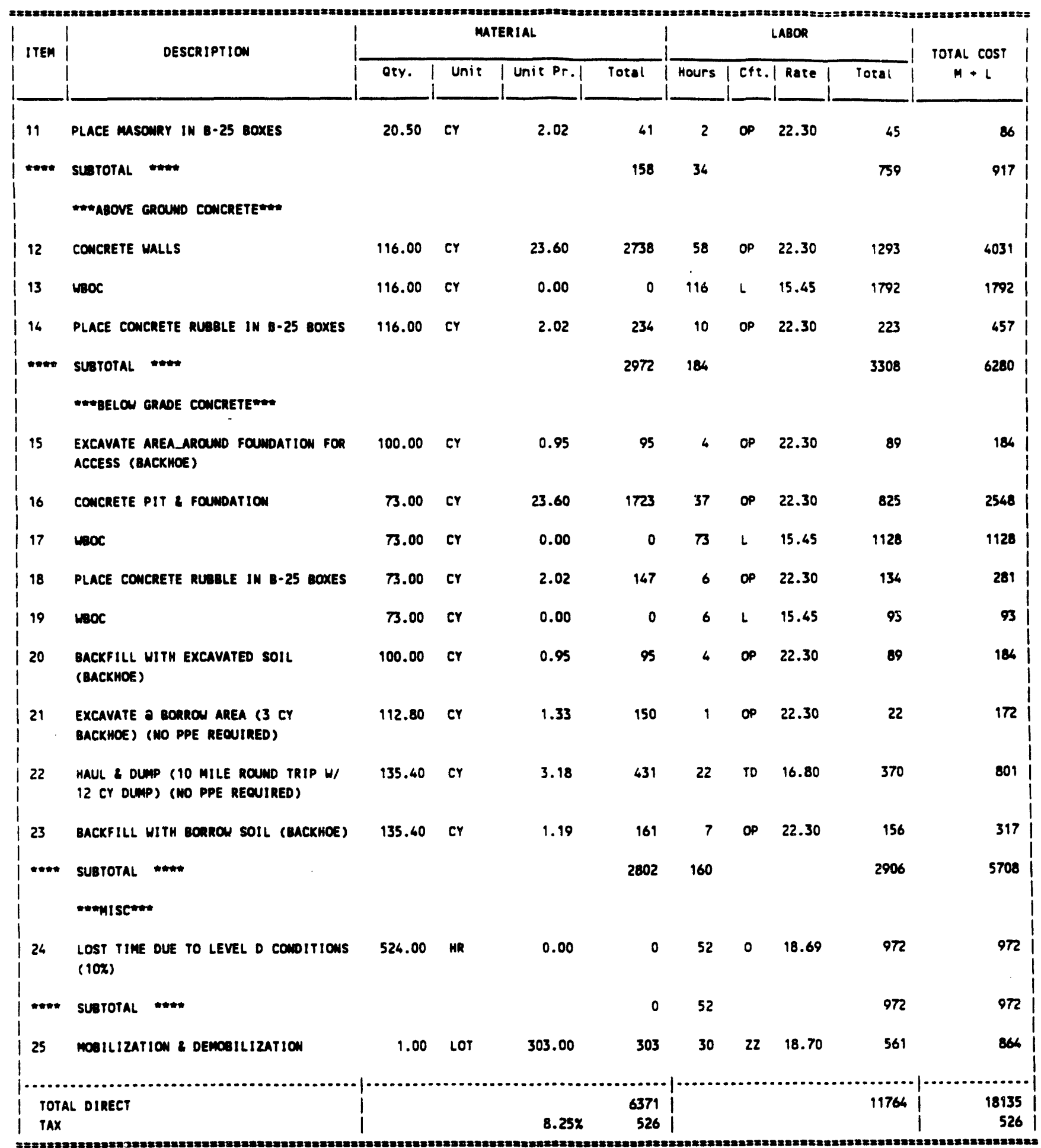


D 2 D NLOG 3506

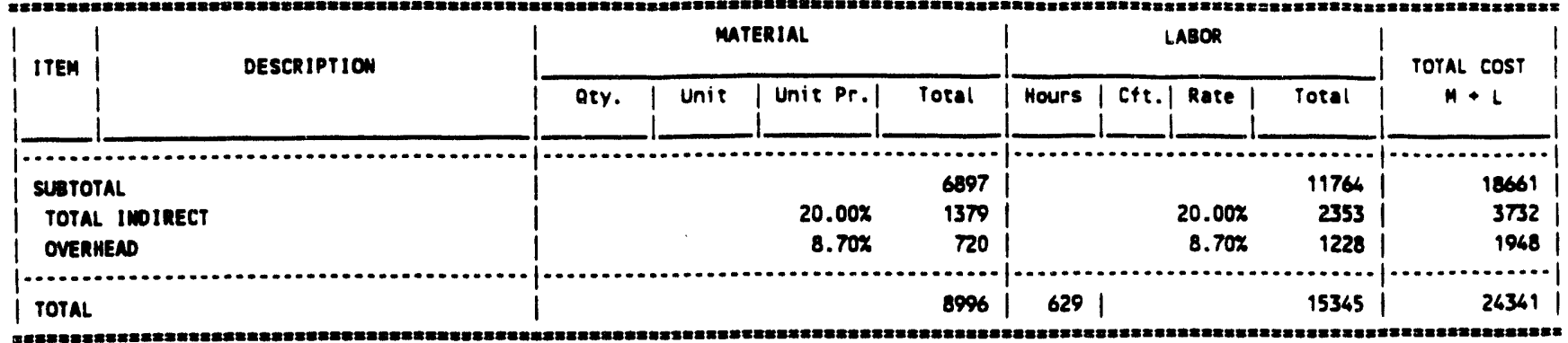




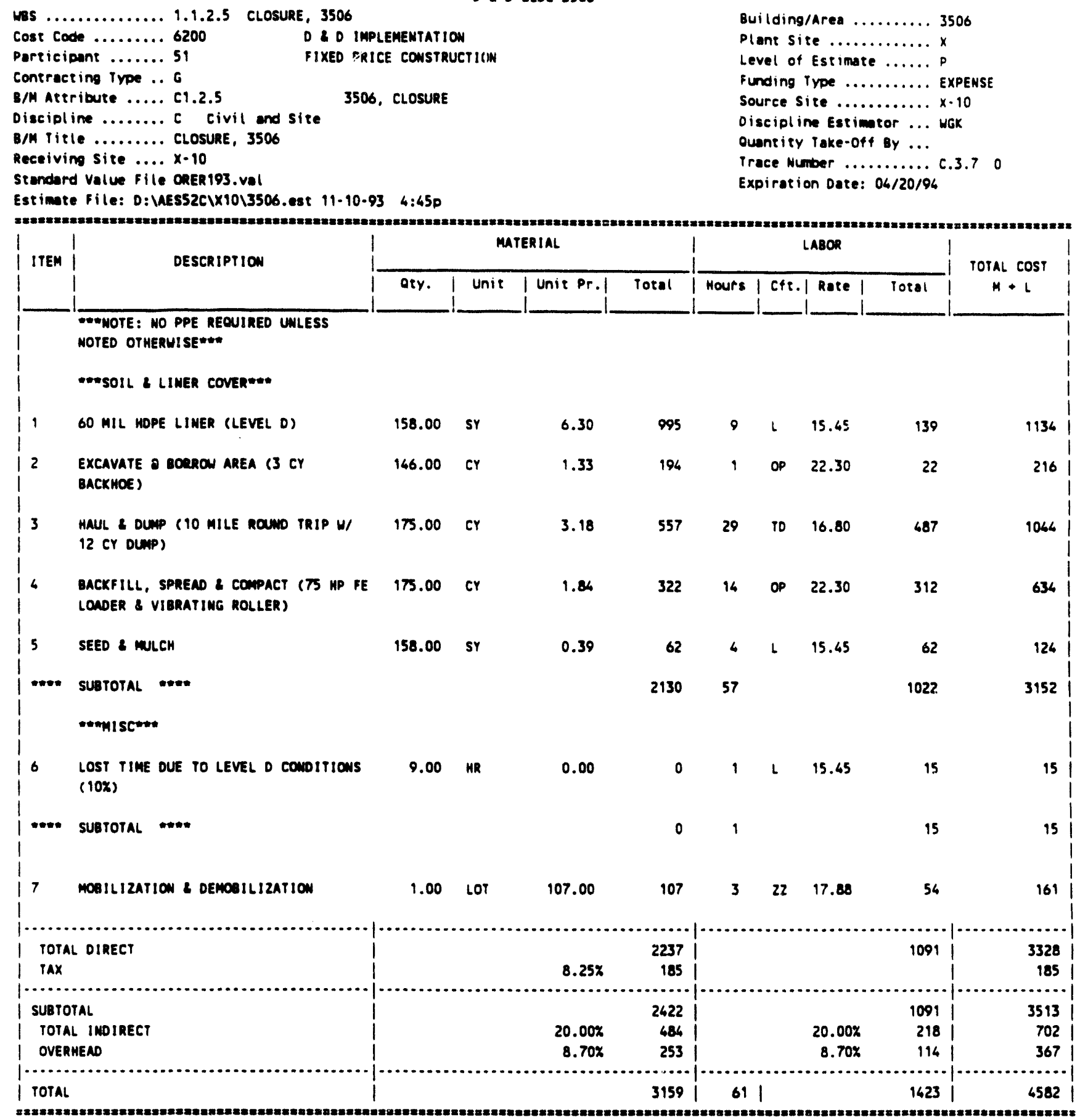




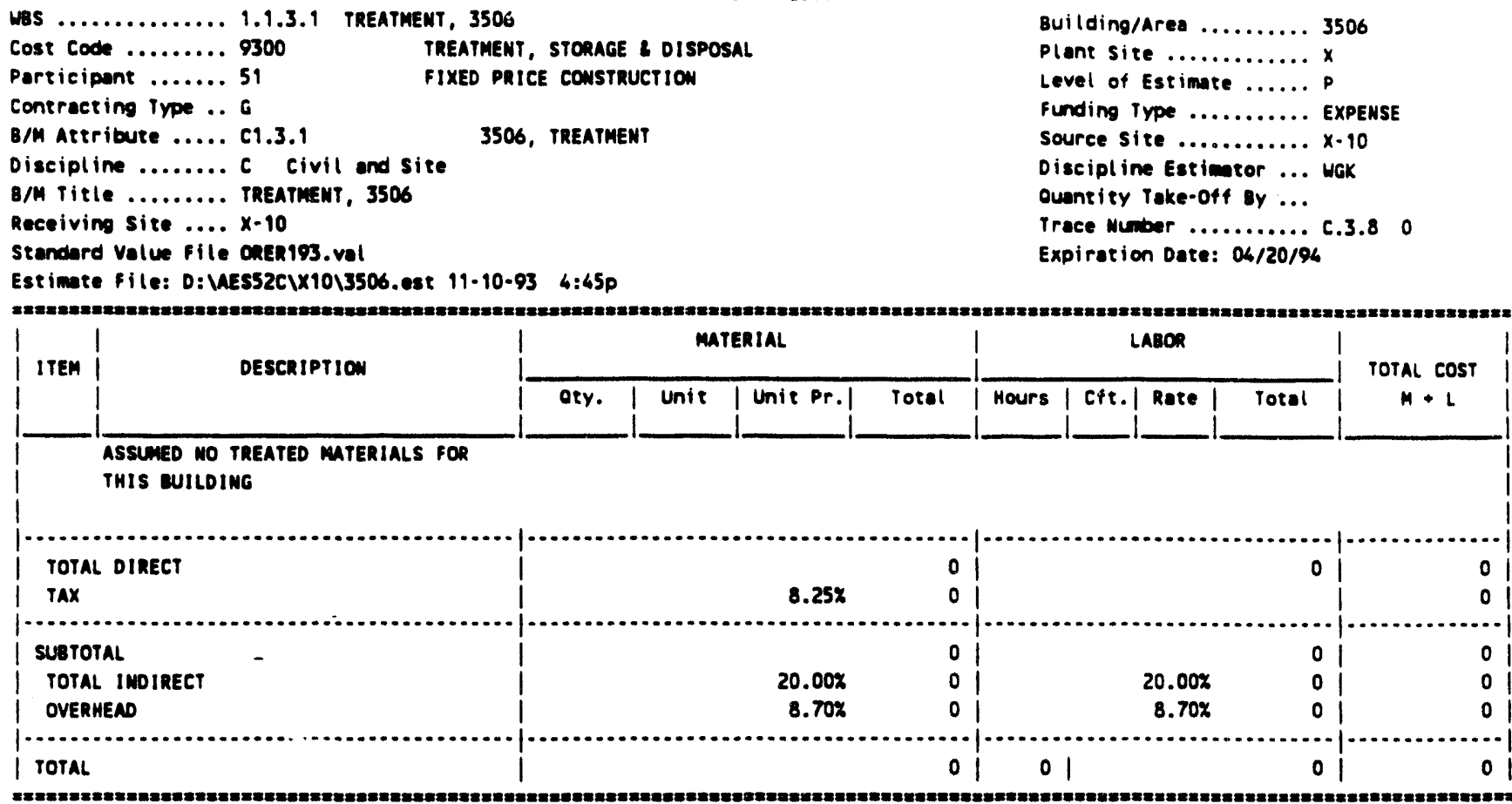




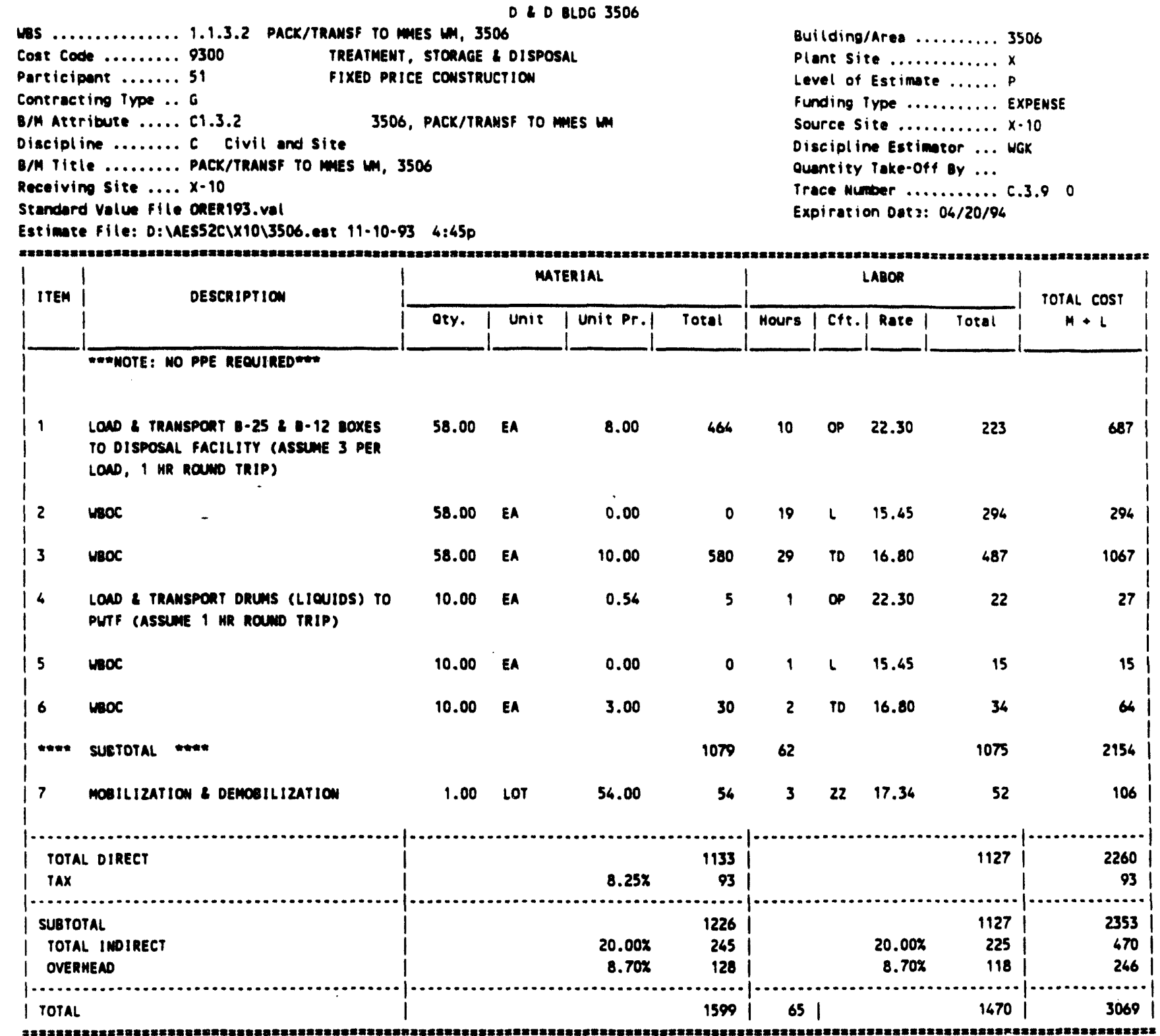




\section{D BLDG 3506}

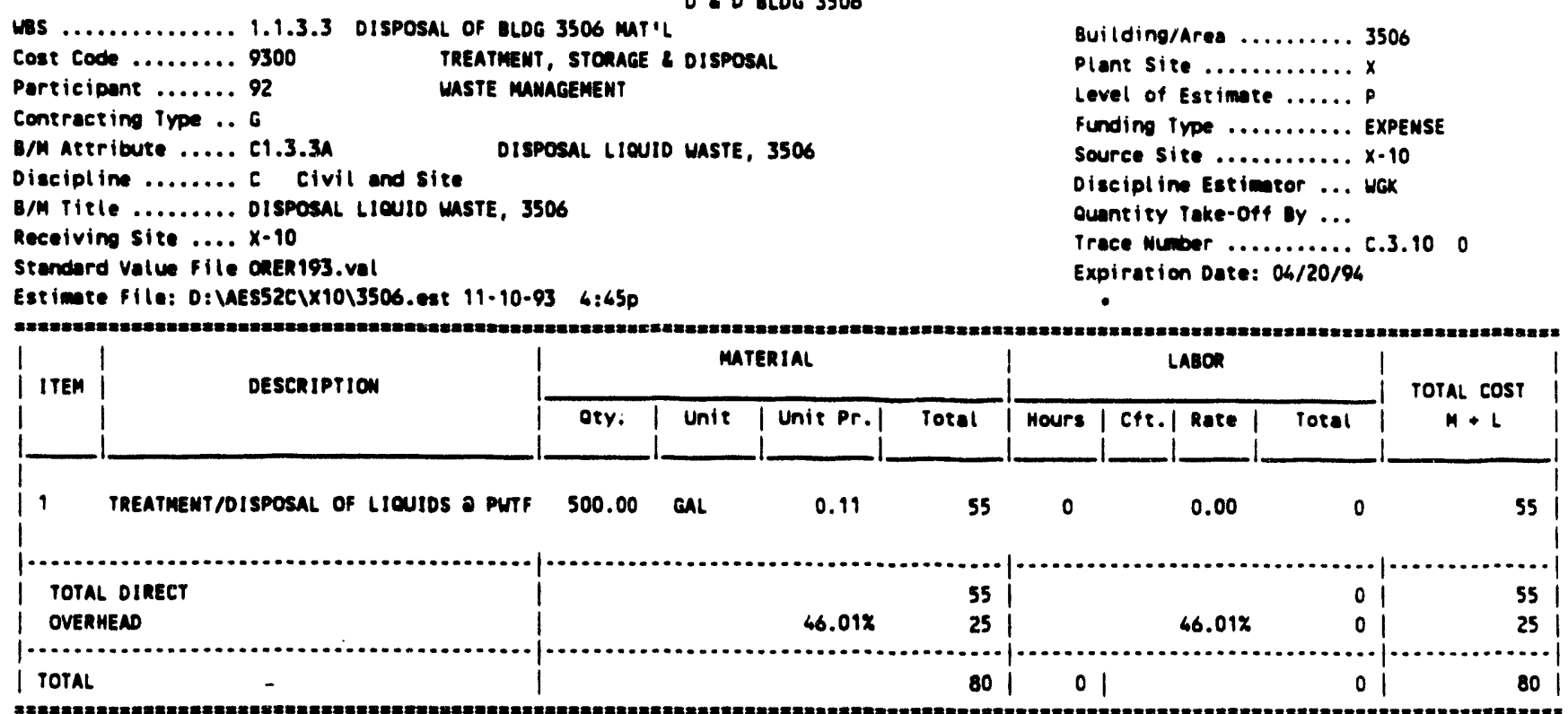


D 30 BLDG 3506

wes $\ldots \ldots \ldots \ldots \ldots 1.1 .3 .3$ DISPOSAL OF BLDG $3506 \mathrm{maT}$ 'L

Cost Code ........ 9300 TREATMENT, STORAEE \& DISPOSAL

Participant ......999 Special

Contracting Irpe .. G

B/M Attribute ..... C1.3.3B

DISPOSAL OF BLDG 3506 MAT'L

Discipline ......... Civil and site

B/M ritle .......... DISPOSAL OF BLDG 3506 MAT'L

Receiving site .... $x-10$

Stendard Value file ORER193.val

Estimate File: D: VAES52CIX1013506.est 11-10.93 4:45p

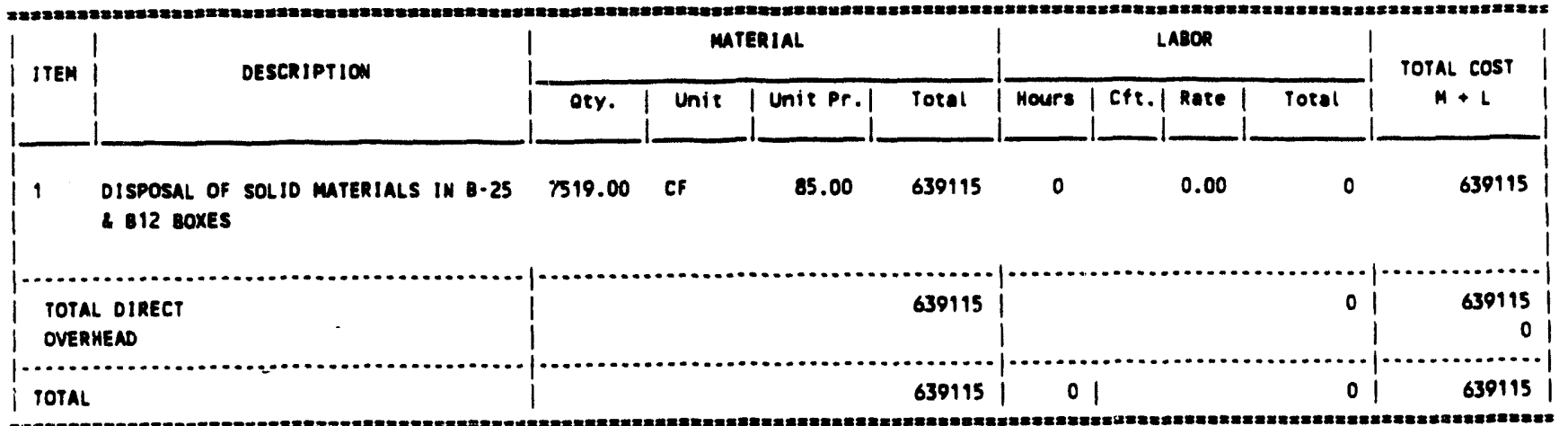

Building/areo ........ 3506

Plant site ............. $x$

Level of Estimate ....... p

Funding type .......... EXPEnSE

Source site ............ $\times-10$

Discipl ine Estimator ... WGK

Quntity Pake-off By ...

Trace Muber ............... c.3.11 0

Expiration Date: $04 / 20 / 94$ 


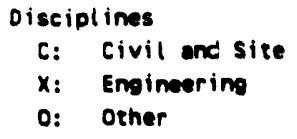

$x$ : Engineering

0 : other

cost sumury

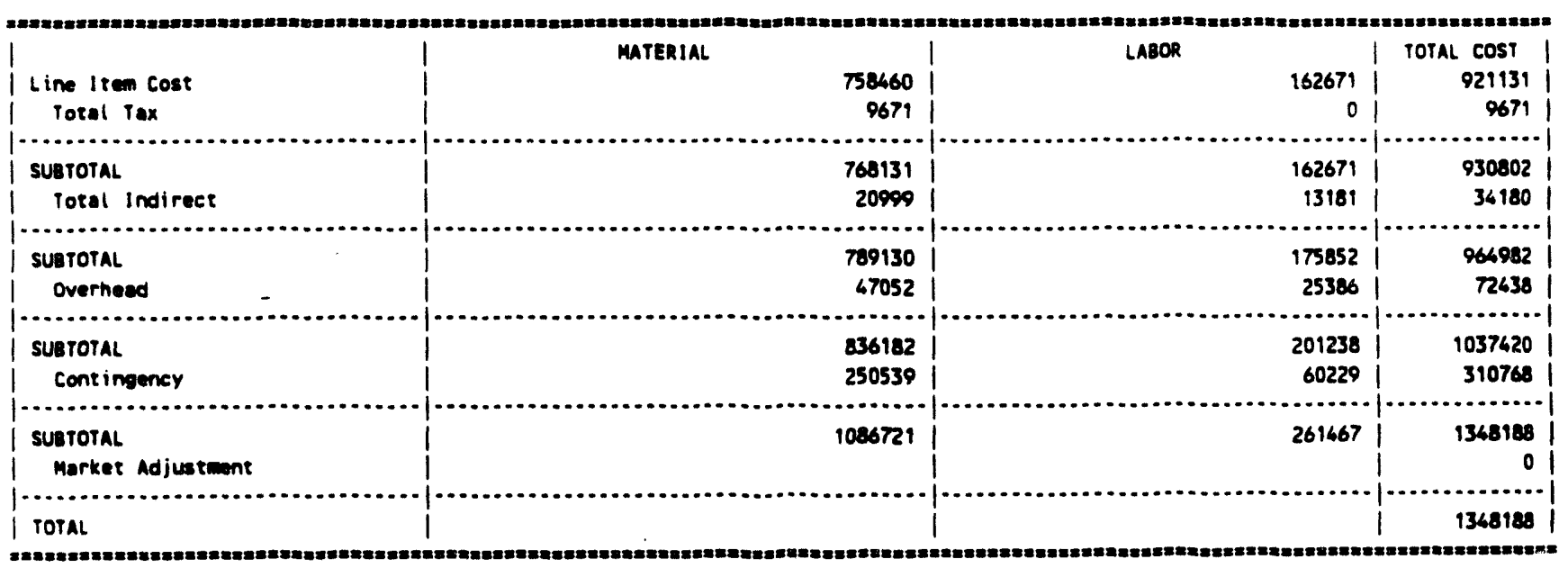


Appendix C.

Cost Estimate for

Complete Dismantlement of Building 3515 
SUMMARY REPORT

Project Nuber: 930031.1

D \& DLDG 3515

Project Eso Numer.......

Revision Numbr..........0

Lese updute............11/10/93

Sort Order

1. uns

2. Porticipant

Approved by:

$\frac{\text { Yeang Kenesen }}{\frac{11-1293}{\text { Dote }}}$

AES Version 5.2c

Base Fiscal Yeor/Ouarter: $93 / 4$

STANDARO VALUE: OAER193.val EXPIRES: $06 / 20 / 94$

ESTIMATE FILE: D: VAES52CIX1013515.est 11/10/93

SCHEDULE FILE: 3515

REPORT FILE : D:IAES52CIX10I3515s.out 11/10/93 16:54:27 


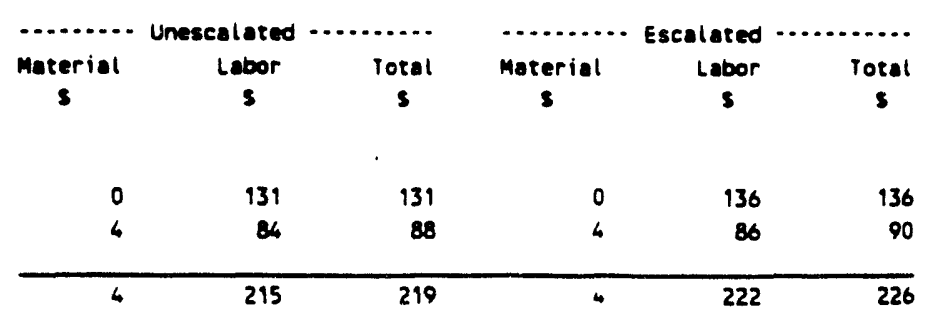

1.2.1.1 PROJECT INTECRATION, 3515

49 mes PROJECT SERVICES

90 ER DIVISIOU

TOTAL PROJECT InTEERATION, 3515

1.2.1.2 TItLE I \& 11 ENGINEERING, 3515

18 A-E TITLE 1 \& II ENCR.

48 MES A-E SUPPORT

TOTAL TITLE I \& II EMgIMEERIMG, 3515

\begin{tabular}{rrrrrr}
0 & 121 & 121 & 0 & 122 & 122 \\
0 & 61 & 61 & 0 & 61 & 61 \\
\hline 0 & 182 & 182 & 0 & 183 & 183
\end{tabular}

1.2.1.3 const newwit a suppont. 3515

66 m-F IMDinects on fin

67 m.F DIRECTS ON FF

TOTAL CONST MOMUT L SUPpont, 3515

\begin{tabular}{rrrrrr}
105 & 0 & 105 & 110 & 0 & 110 \\
3 & 222 & 225 & 3 & 230 & 233 \\
\hline 108 & 222 & 330 & 113 & 230 & 343
\end{tabular}

1.2.1.4 TITLE III ENGINEERING, 3515

13 MES TITLE III ENCR.

19 a-E tItLE III ener.

TOTAL TITLE III ENGIMELRIMG, 3595

\begin{tabular}{rrrrrr}
9 & 161 & 170 & 10 & 169 & 179 \\
0 & 43 & 43 & 0 & 45 & 45 \\
\hline 9 & 204 & 213 & 10 & 216 & 224
\end{tabular}

1.2.2 BILOIMG 3515 D \& 0

61 mES FIELD MINTEMANCE

S1 FIXED PRICE COASTRUCTION

TOTAL BUILDIMG 3515 D $\&$

\begin{tabular}{rrrrrr}
299 & 1 & 300 & 314 & 1 & 315 \\
776 & 51 & 357 & 322 & 53 & 375 \\
\hline 605 & 52 & 657 & 636 & 54 & 690
\end{tabular}

1.2.2.1 INITIAL CMARACTERIZATION, 3515

51 FIXED PRICE COUSTRUCTION

TOTAL INITIAL CHARACTERIZATION, 3515

\begin{tabular}{lrrrrr}
6 & 26 & 30 & 6 & 25 & 31 \\
\hline 6 & 24 & 30 & 6 & 25 & 31
\end{tabular}


D \& OLDG 3515

SUMARYY REPORT

$\$ 1=\$ 1000$

$11 / 10 / 93$

Arranged Oy: ws / Participant

1.2.2.2 ECUIPMENT REMOVAL, 3E is

51 FIXED PRICE COASTRUCTION

TOTAL EOUIPNENT REAONAL, 3515

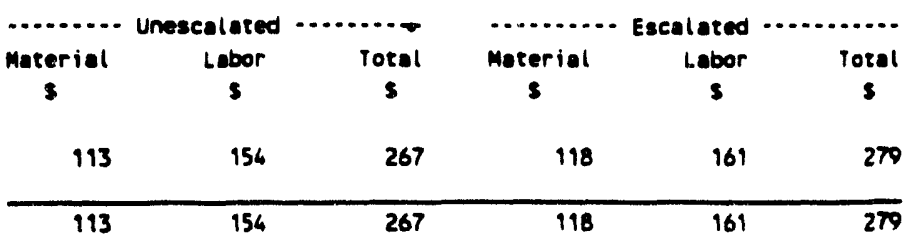

1.2.:.3 DECOMTAMIMATION, 3515

51 FIXED PRICE COnstruction

TOTAL DEcontamimation, 3515

\begin{tabular}{llllll}
0 & 0 & 0 & 0 & 0 & 0 \\
\hline 0 & 0 & 0 & 0 & 0 & 0
\end{tabular}

1,2.2.4 DIswatle stauctune, 3515

51 FIXED PRICE COAstRUCTION

TOTAL DISWANLE STRuctuRE, 3515

\begin{tabular}{llllll}
48 & 90 & 138 & 51 & 95 & 146 \\
\hline 48 & 90 & 138 & 51 & 95 & 146
\end{tabular}

1.2.2.5 CLOSURE, 3515

51 FIXED PRICE COAsTnUCTION

TOTAL CLOSUNE, 3515

\begin{tabular}{llllll}
6 & 3 & 9 & 6 & 3 & 9 \\
\hline 6 & 3 & 9 & 6 & 3 & 9
\end{tabular}

1.2.3.1 TREATUENT, 3515

51 FIXED PRICE construction

TOTAL TREATMENT, 3515

\begin{tabular}{llllll}
0 & 0 & 0 & 0 & 0 & 0 \\
\hline 0 & 0 & 0 & 0 & 0 & 0
\end{tabular}

1.2.3.2 PACK/TRAMSF TO MUES MA, 3515 59 FIXED. PRICE CONSTRUCTION

TOTAL PACK/TRANSF TO mES IM, 3515

\begin{tabular}{llllll}
2 & 2 & 4 & 2 & 2 & 4 \\
\hline 2 & 2 & 4 & 2 & 2 & 4
\end{tabular}

1.2.3.3 DISPOSAL OF BLOG 3515 MAT'L 92 UASTE MANACENENT

9 SPECIAL

TOTAL DISPOSAL OF BLUE 3515 mAT'L

\begin{tabular}{rrrrrr}
0 & 0 & 0 & 0 & 0 & 0 \\
629 & 0 & 629 & 661 & 0 & 661 \\
\hline 629 & 0 & 629 & 661 & 0 & 661
\end{tabular}




\section{D \& D BLD 3515}

\section{SUMURYY REPORT}

\section{$\$ 1=\$ 1000$ \\ $11 / 10 / 93$}

Arranged By: was / Participant

SUB - TOTAL CONTIMEENCY

GRAND TOTAL

\begin{tabular}{|c|c|c|c|c|c|}
\hline $\begin{array}{c}\text { Material } \\
s\end{array}$ & $\begin{array}{c}\text { Labor } \\
5\end{array}$ & $\begin{array}{c}\text { Total } \\
5\end{array}$ & $\begin{array}{c}\text { Material } \\
s\end{array}$ & $\begin{array}{c}\text { Labor } \\
\$\end{array}$ & $\begin{array}{c}\text { Total } \\
5\end{array}$ \\
\hline 1530 & 1148 & 2678 & 1607 & 1189 & 2796 \\
\hline 503 & 393 & 896 & 529 & 408 & 937 \\
\hline 2033 & 1561 & 3574 & 2936 & 1597 & 3733 \\
\hline
\end{tabular}

\section{C-6}


DETAIL REPORT

Project Number: 930031.1

D \& D BLOG 3515

Project EsO Numer.......

Revision Number..........0

Last Update............11/10/93

Sort Order

1. whs

2. Participant

3. $1 / M$ Attribute

Approved by:

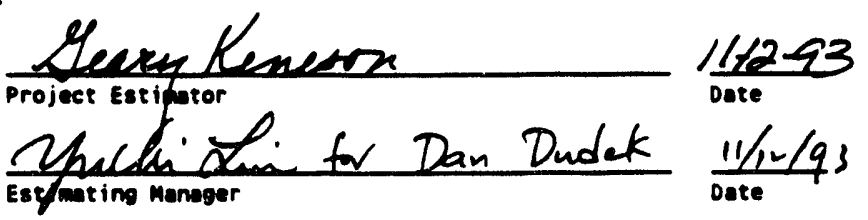

AES Version 5.26

Base fiscel Year/ounrter: $93 / 4$

STAMDARD VALUE: ORER193.val EXPIRES: 06/20/94

ESTIMATE FILE: D:UAES52CIX1013515.est $11 / 10 / 93$

SCMEDULE FILE: 3515

REPORT FILE : D:LAES52CIX10135150.out 11/10/93 16:49:15 


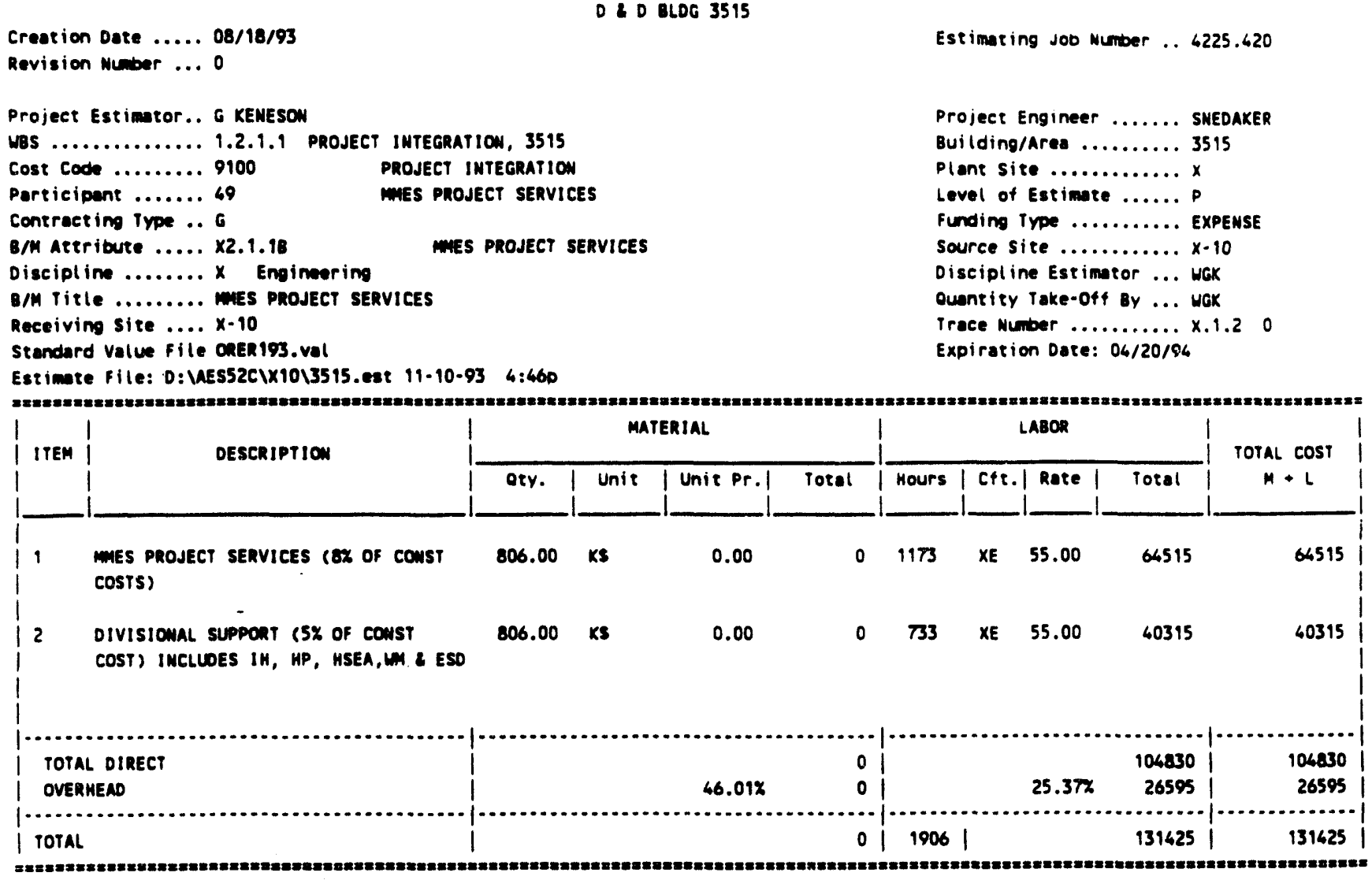


DE DLDG 3515

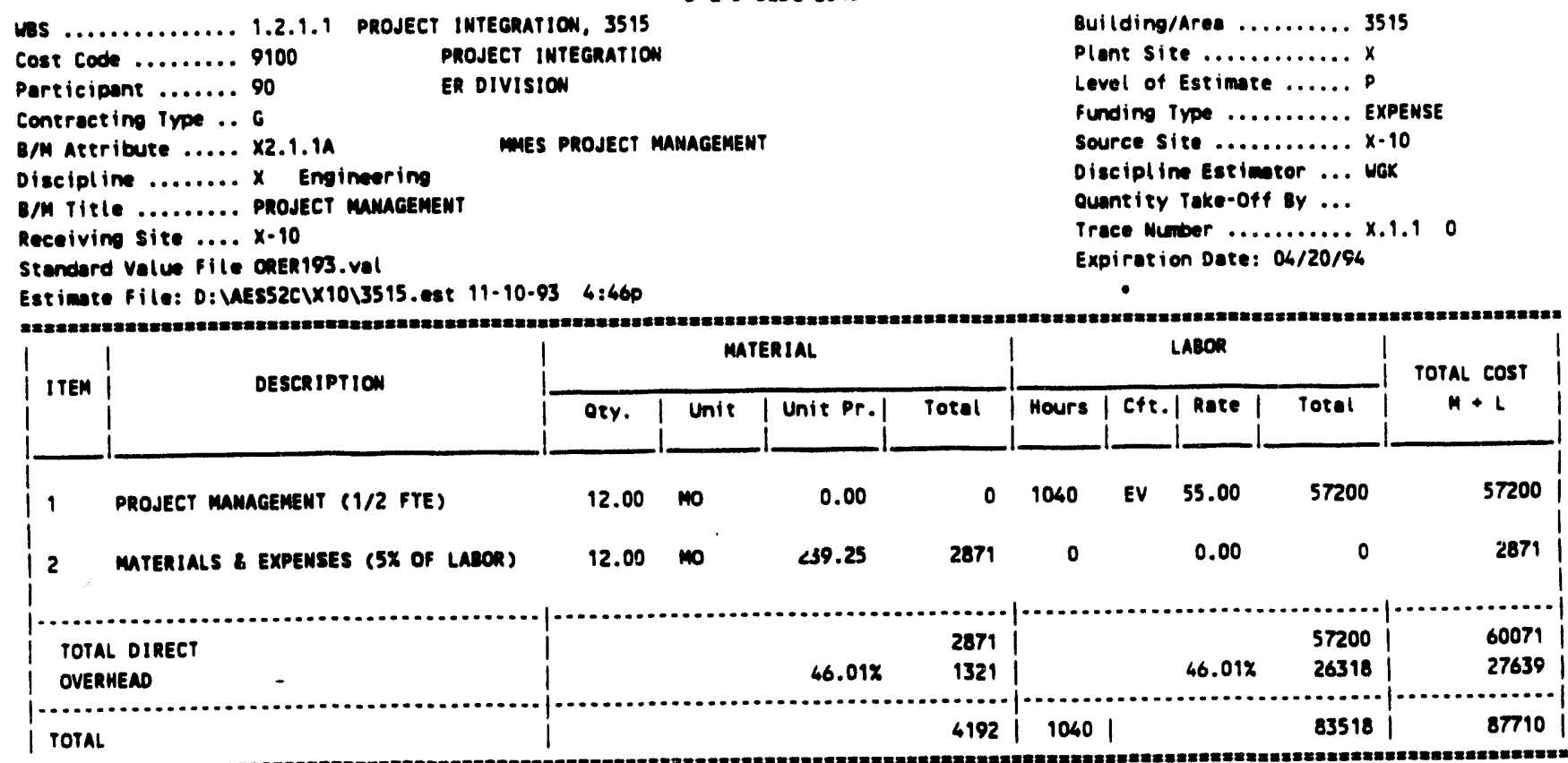


O \& DLOG 3515

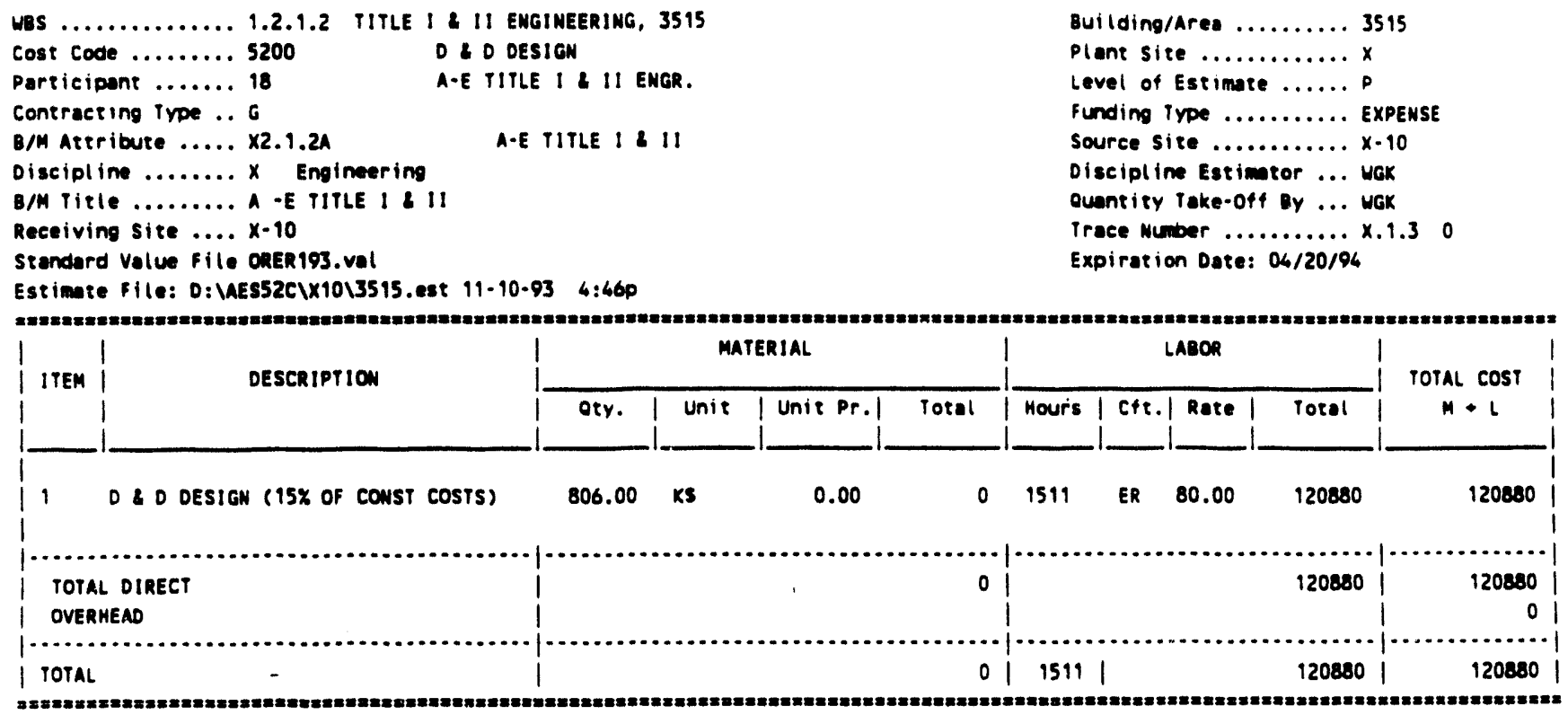




\section{D ALDG 3515}

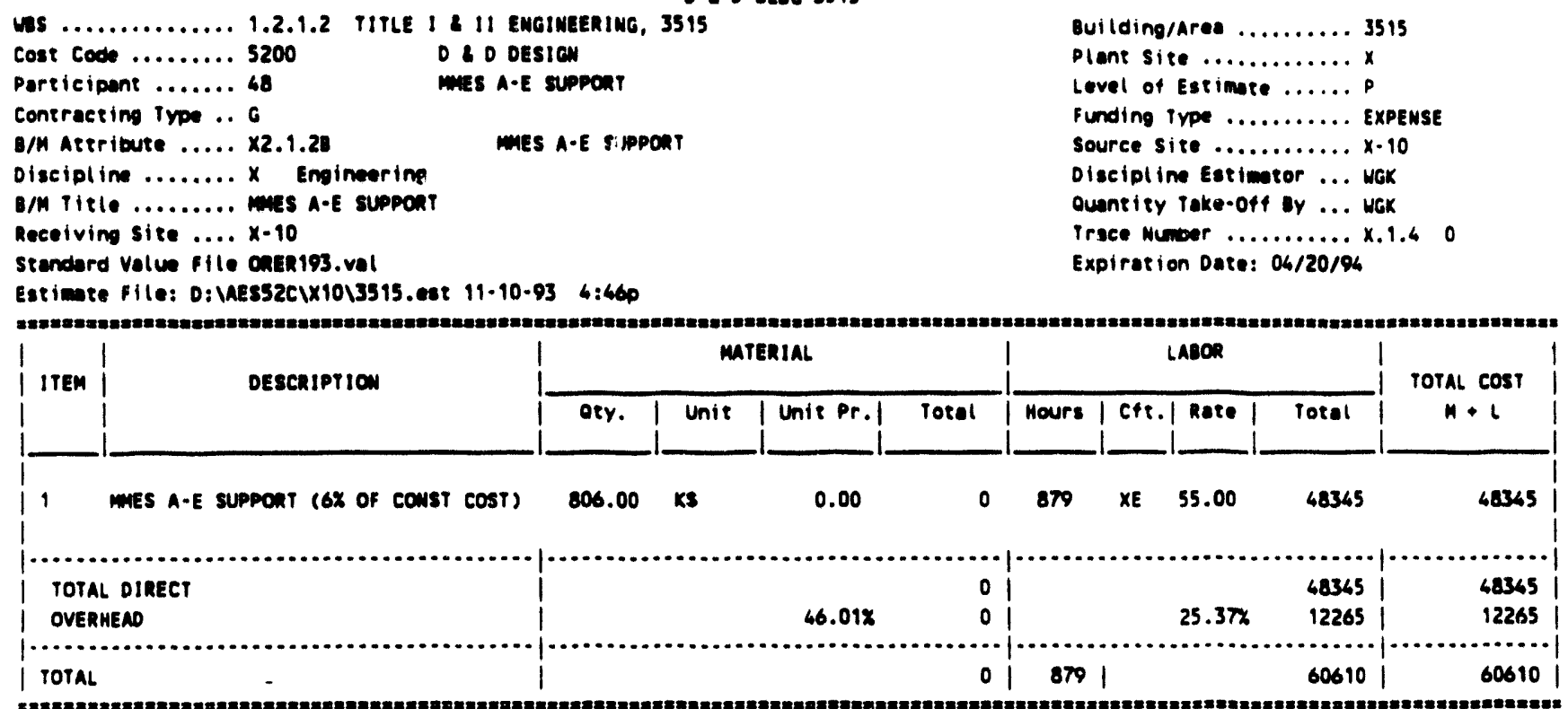


D \& D LLDO 3515

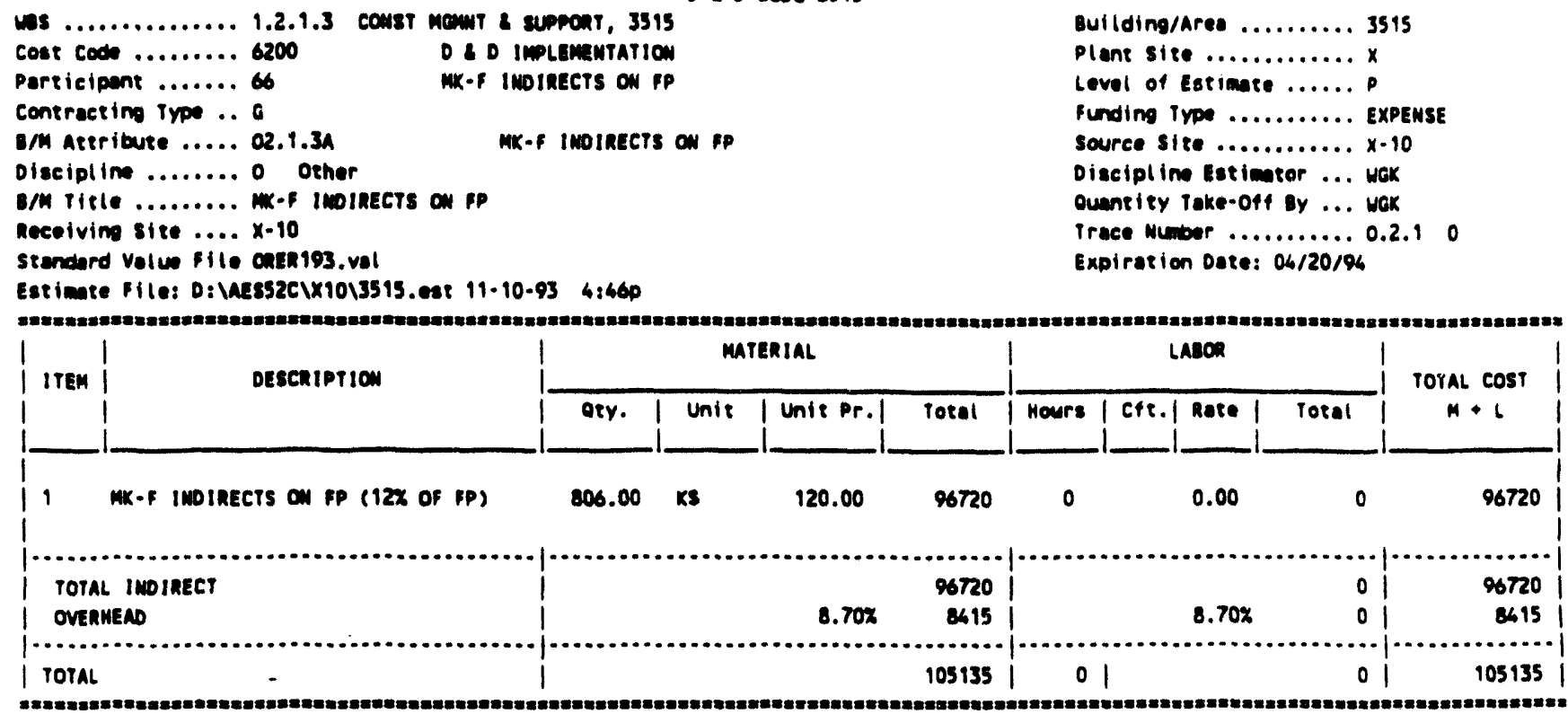


D 2 olog 3515

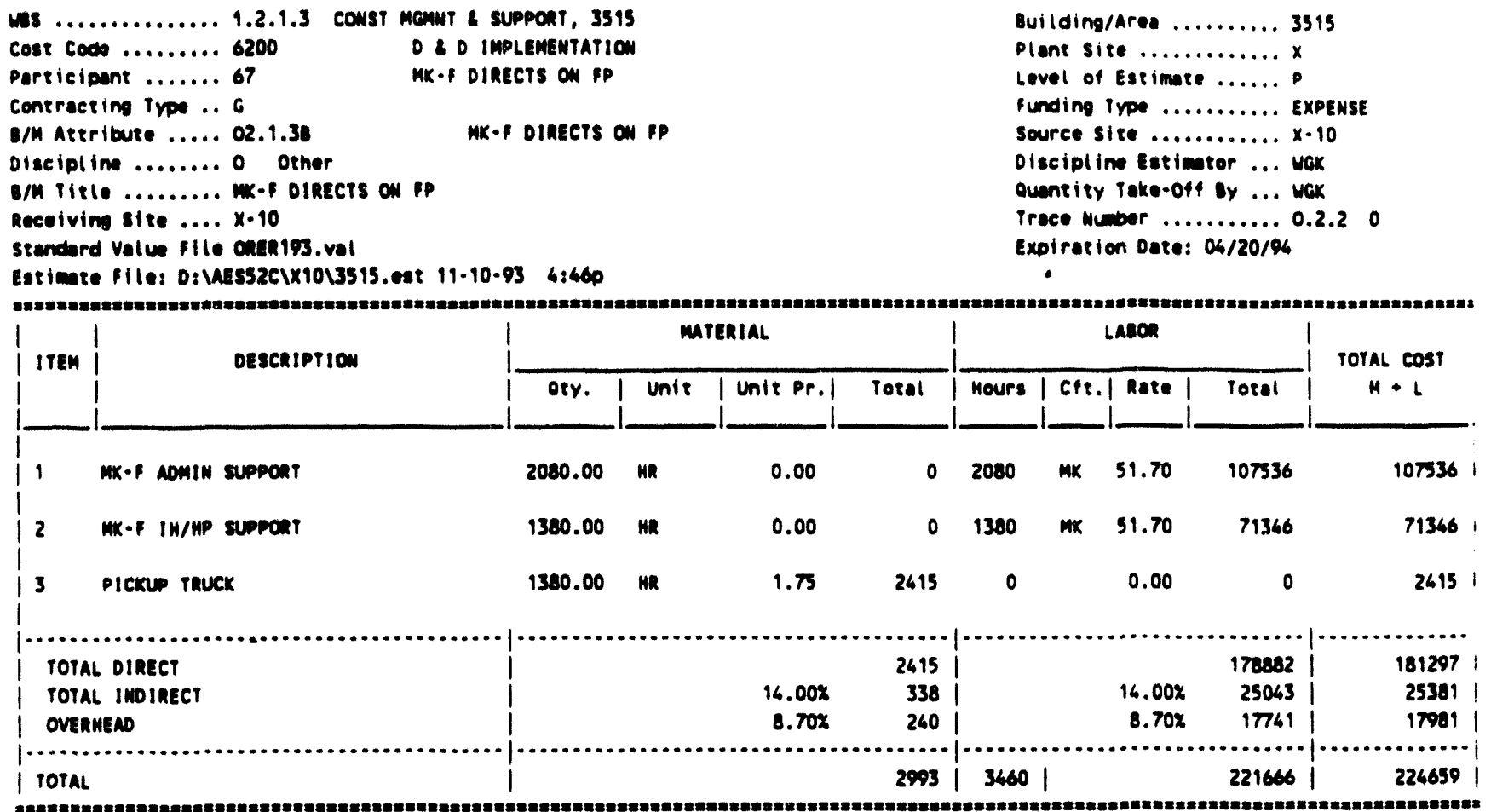

\section{C-13}


DE D ILDG 3515

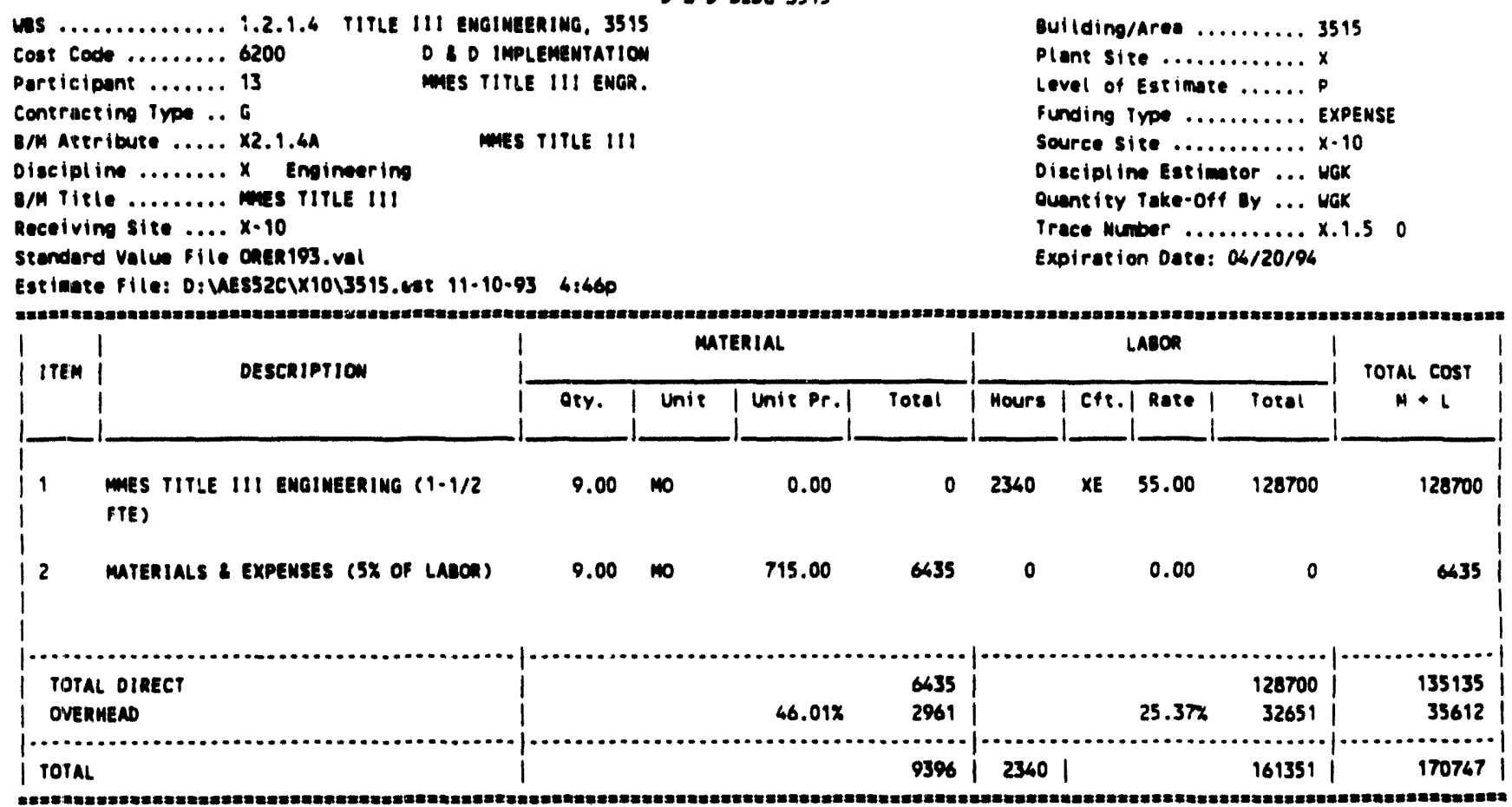


D 20 OLDO 3515

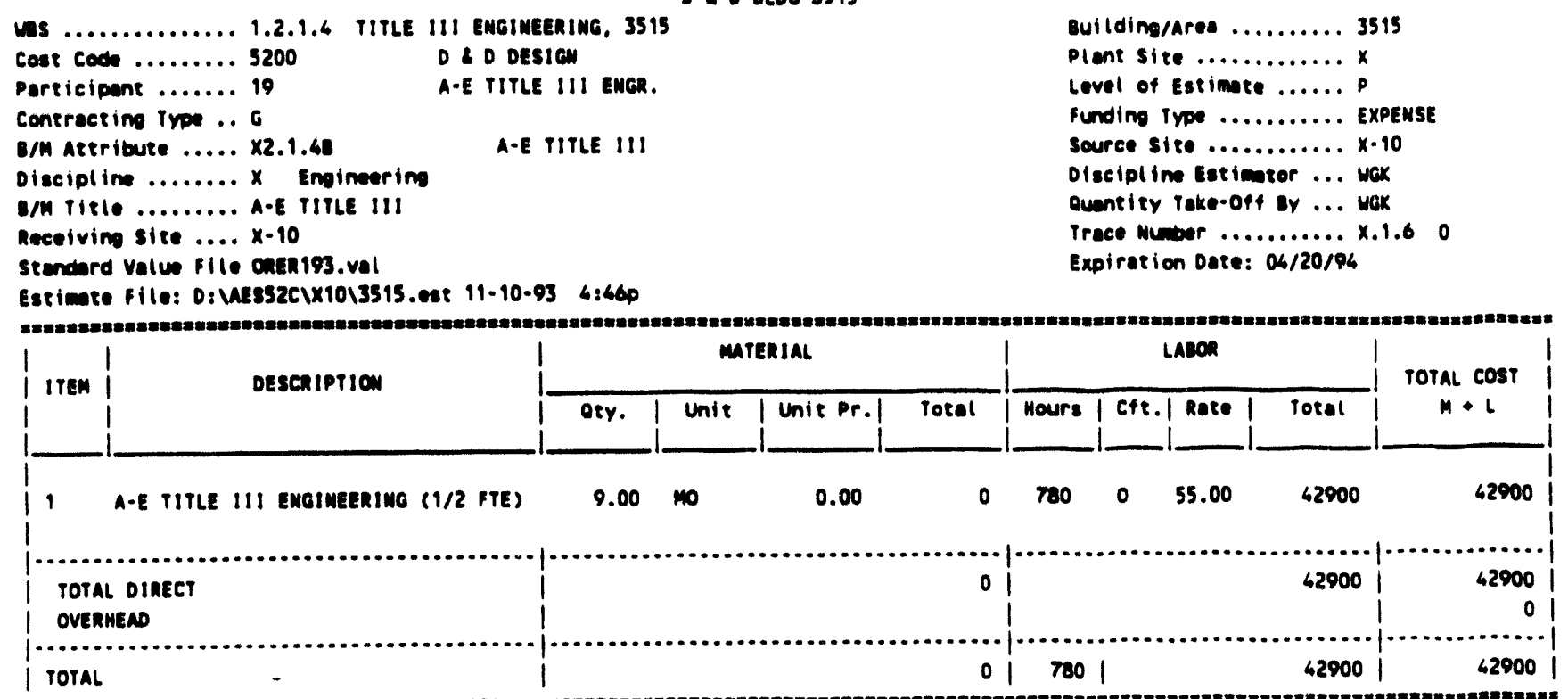

\section{C-15}


DL D BLDG 3515

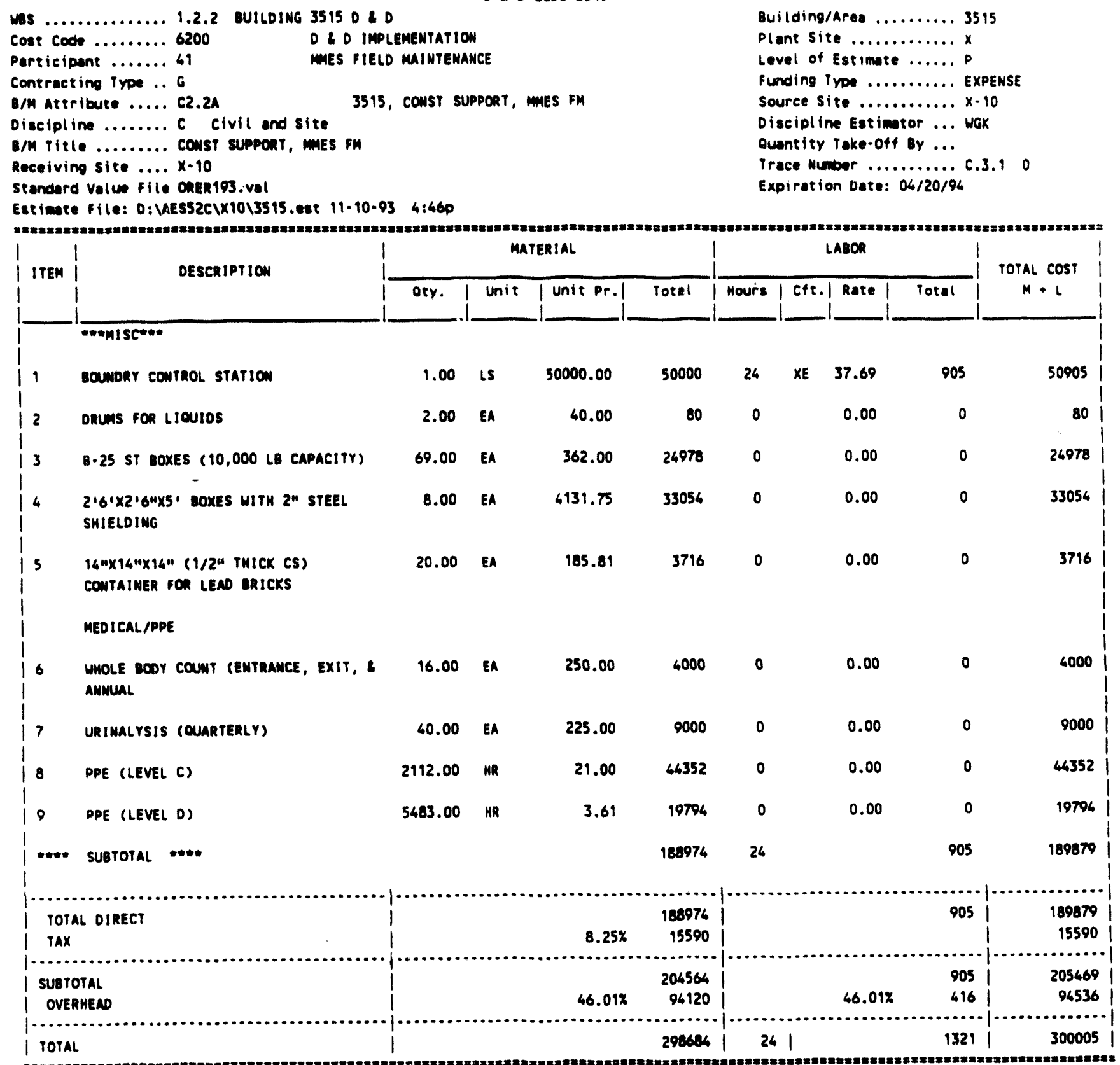


D. OLOG 3515

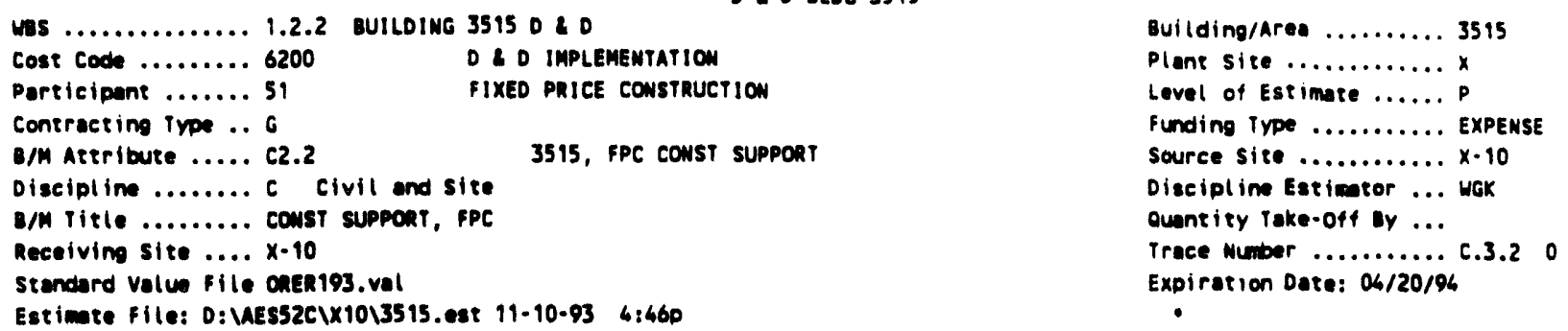

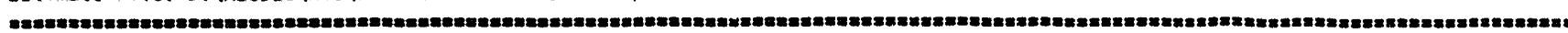

\begin{tabular}{|c|c|c|c|c|c|c|c|c|c|c|}
\hline \multirow{2}{*}{ ITEM } & \multirow{2}{*}{ DESCRIPTION } & \multicolumn{4}{|c|}{ MATERIAL } & \multicolumn{4}{|c|}{ LABOR } & \multirow{2}{*}{$\begin{array}{c}\text { Total cost } \\
M+L\end{array}$} \\
\hline & & Qty. & Unit & Unit Pr.I & Total & Hours & $c+t .1$ & Rate & Toral & \\
\hline 1 & MEALTH \& SAFETY PLAN & 1.00 & LS & 0.00 & 0 & 60 & 0 & 75.00 & 4500 & 4500 \\
\hline 2 & COWPREMENSIVE WORK PLAN & 1.00 & LS & 0.00 & 0 & $\pi 5$ & 0 & 75.00 & 5625 & 5625 \\
\hline mmen & SUPTOTAL Wut & & & & 0 & 135 & & & 10125 & 10125 \\
\hline
\end{tabular}

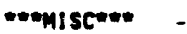

REMOTE MANIPULATCRS

1.00 LS $\quad 100000.00 \quad 100000$

$0 \quad 0.00$

$0 \quad 100000$

435 TON CRAME (nENTAL)

$8.00 \quad 100 \quad 6000.00 \quad 48000$

1.00 LS $\quad 25000.00 \quad 25000$

0.00

0

68000

5 MEPA FILTER SYSTEM FON USE DUNIMG DENO ACTIVITIES (INCLLDES MOA/DEMCS)

6 misc ToOLs a EOUIP

$\begin{array}{llll}1.00 \quad \text { is } & 2500.00 \quad 2500\end{array}$

0.00

0

25000

7 MYD SHEARS, REmOTE OPERATEO

1.00 LS $\quad 7500.00 \quad 7300$

0

0.00

0

2500

$\begin{array}{lll}1.00 \text { LS } \quad 4500.00 & 4500\end{array}$

80

0.00

0

7500

TemponanY POWER

OFFICE TRALLER

1.00 LS

5000.00

5000

192500

0
80

22.95

1836

6336

tom subtotal mome

TRAINING/PHYSICALS/ETC

ASSUNE SOX OF WORKERS PREVIOUSLY

TRAINED

$10 \quad 40$ Moun sara/osma trainIMO

$8.00 \quad \mathrm{EA}$

750.00

320

25.00

8000

14000

8.00 EA

730.00

6000

25.00

8000

14000 (AMMULAL)

12 suncontanacton oRIETATION, MeET" TRAINING (EVERY 2 YEARS)

8.00 EA

0.00

0

25.00

600

600

13 RAD IORKER TRAINIMG (EVERY 2 YEARS)

$8.00 E A$

250.00

2000

192025.00

4800

6800

14 PHYSICAL EXAM (ENTRANCE, EXIT, 2

32.00 EA

300.00

960

1280

25.00

3200

12800 
D\& D I ... 3515

\begin{tabular}{|c|c|c|c|c|c|c|c|c|c|c|c|}
\hline \multirow{2}{*}{ ITEM } & \multirow{2}{*}{\multicolumn{2}{|c|}{ DESCRIPTION }} & \multicolumn{4}{|c|}{ mitenial } & \multicolumn{4}{|c|}{ LABOR } & \multirow{2}{*}{$\begin{array}{c}\text { TOTAL Cost } \\
M \bullet L\end{array}$} \\
\hline & & & oty. & Unit & Unie Pr.| & Total & Hours & Cft & | Rate | & Total & \\
\hline 15 & $\begin{array}{l}\text { woLE coor } \\
\text { ANMUAL }\end{array}$ & COUNT (ENTRAMCE, EXIT, B & 16.00 & EA & 0.00 & 0 & 48 & 0 & 25.00 & 1200 & 1200 \\
\hline 17 & RESPIRATOR & FIT (AMMUAL) & 6.00 & EA & 105.00 & 420 & 4 & 0 & 25.00 & 100 & 520 \\
\hline 18 & DOSIMETERS & ( 1 PER WORKER PER OTR) & 36.00 & EA & 15.00 & 540 & .0 & & 0.00 & 0 & 560 \\
\hline 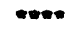 & SUETOTAL & $\infty$ & & & & 24560 & 1076 & & & 26900 & 51460 \\
\hline Tota & IL DIRECT & & & & & 217060 & & & & 38261 & 255921 \\
\hline To & & & & & $8.25 x$ & 17907 & & & & & 17907 \\
\hline susto & ITAL & - & & & & $234 \% 67$ & & & & 38261 & 273828 \\
\hline rota & IL IMOIRECT & & & & $20.00 x$ & 46993 & & & $20.00 \%$ & $T 772$ & 56765 \\
\hline OVER & & & & & $8.70 x$ & 24531 & & & $8.70 x$ & 4057 & 28588 \\
\hline TOTAL & & & & & & 306491 & 1291 & & & 50690 & 357181 \\
\hline
\end{tabular}


D 20 LLOG 3515

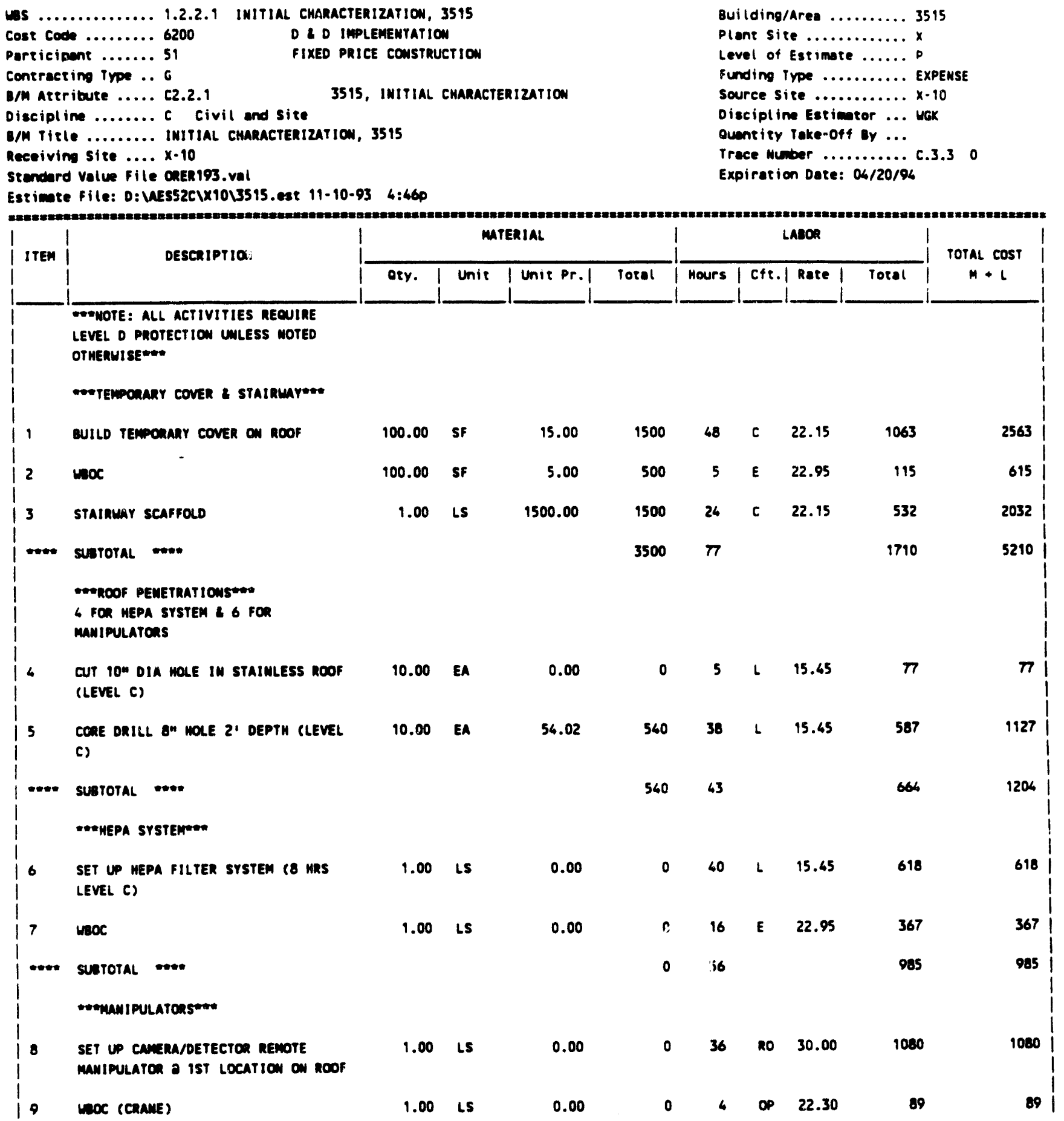


D \& D BLOG 3515

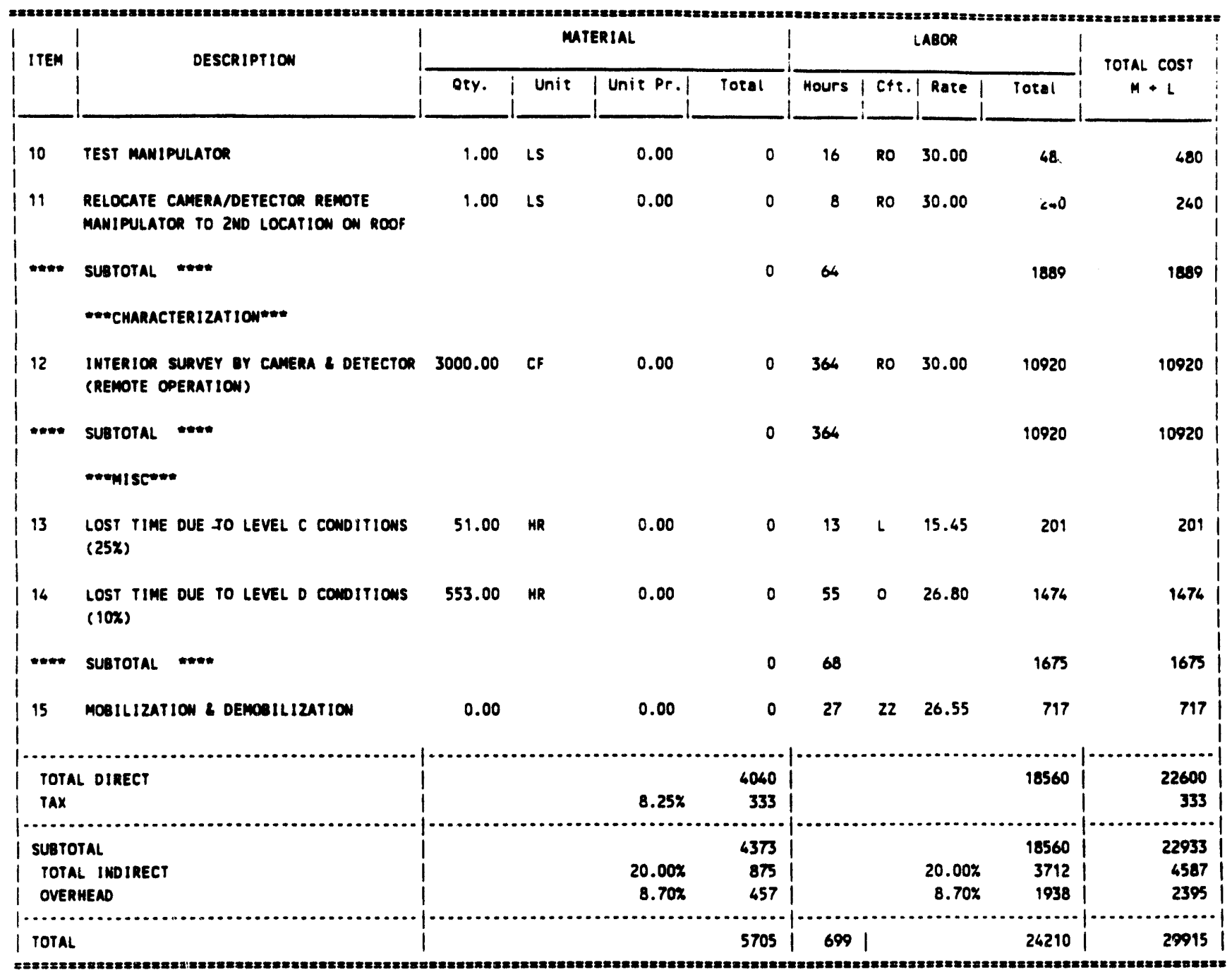




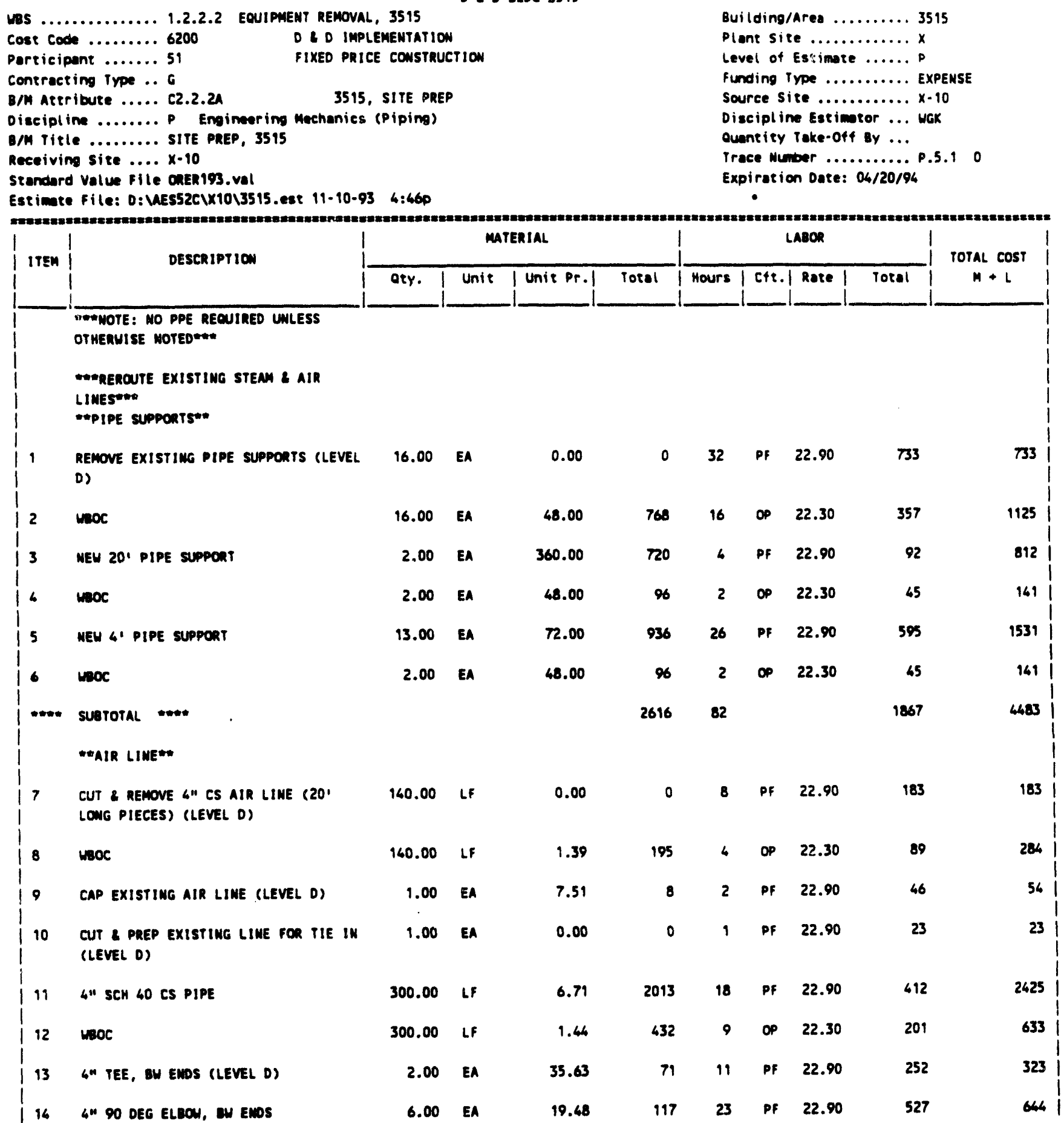


D 2 BLDG 3515

\begin{tabular}{|c|c|c|c|c|c|c|c|c|c|c|}
\hline \multirow{2}{*}{ ITEN } & \multirow{2}{*}{ DESCRIPTION } & \multicolumn{4}{|c|}{ MATERIAL } & \multicolumn{4}{|c|}{ LABOR } & \multirow{2}{*}{$\begin{array}{c}\text { TOTAL } \cos T \\
M+l\end{array}$} \\
\hline & & oty. & Unit & Unit Pr. I & Potal & Hours & $c+t .1$ & Rate | & Total & \\
\hline 15 & $\begin{array}{l}\text { CAP ONE EWD OF MEH TEE (WELO TIME } \\
\text { IMCLUDED IN TEE COST) }\end{array}$ & 1.00 & $E A$ & 7.51 & 8 & 0 & & 0.00 & 0 & 8 \\
\hline +out & SUETOTAL mon & & & & 2844 & 76 & & & 1733 & $45 \pi$ \\
\hline & "*STEAM LIME"* & & & & & & & & & \\
\hline ic & $\begin{array}{l}\text { REMOVE PIPE INSULATION \& PLACE IN } \\
\text { ONE B-25 BOX (LEVEL C) }\end{array}$ & 180.00 & LF & 0.00 & 0 & 36 & $A H$ & 25.45 & 916 & 9161 \\
\hline 17 & $\begin{array}{l}\text { CUT \& REMOVE ON CS STEAM LINE (20' } \\
\text { LONG PIECES) (LEVEL D) }\end{array}$ & 180.00 & LF & 0.00 & 0 & 20 & PF & 22.90 & 458 & 458 \\
\hline 18 & woc & 180.00 & LF & 2.64 & 475 & 10 & OP & 22.30 & 223 & 698 \\
\hline 19 & CAP EXISTING STEAM LINE (LEVEL D) & 1.00 & EA & 20.43 & 20 & 4 & PF & 22.90 & 92 & 112 \\
\hline 20 & $\begin{array}{l}\text { CUT \& PREP EXISTING LINE FOR TIE IN } \\
\text { (LEVEL O) }\end{array}$ & 1.00 & EA & 0.00 & 0 & 1 & PF & 22.90 & 23 & 23 \\
\hline 21 & 8" SCH 40 CS PIPE & 300.00 & LF & 17.16 & 5148 & 33 & PF & 22.90 & $\pi 56$ & 5904 \\
\hline 22 & wsoc & 300.00 & LF & 2.64 & 792 & 17 & $O P$ & 22.30 & 379 & 1171 \\
\hline 23 & B" TEE, BU ENDS (LEVEL D) & 2.00 & EA & 121.13 & 242 & 22 & PF & 22.90 & 504 & 746 \\
\hline 24 & 8" 90 DEG ELBOW, BH ENDS & 6.00 & EA & 87.40 & 524 & 43 & PF & 22.90 & 985 & 1509 \\
\hline 25 & $\begin{array}{l}\text { CAP ONE END OF MEH TEE (WELD TIME } \\
\text { IMCLLDED IN TEE COST) }\end{array}$ & 1.00 & $\varepsilon A$ & 20.43 & 20 & 0 & & 0.00 & 0 & 20 \\
\hline 26 & 2" fiberglass IMSULATION (LEVEL C) & 310.00 & LF & 8.25 & 2558 & 62 & AW & 25.45 & 1578 & 6136 \\
\hline 27 & .016" ALUM JACKET & 1071.00 & SF & 0.54 & 578 & 142 & $A H$ & 25.45 & 3614 & 4192 \\
\hline 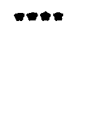 & SUBTOTAL "Wom & & & & 10357 & 390 & & & 9528 & 19805 \\
\hline 28 & WELDING MACHINE & 80.00 & MR & 7.50 & 600 & 0 & & 0.00 & 0 & 600 \\
\hline 29 & FIRE WATCM ( $50 \%$ LEVEL D) & 100.00 & HR & 0.00 & 0 & 100 & $\downarrow$ & 15.45 & 1545 & 1545 \\
\hline 30 & PIPE CLEANING & 1.00 & LS & 0.00 & 0 & 12 & PF & 22.90 & 275 & 275 \\
\hline 31 & PIPE TESTIMG & 12.00 & HR & 35.00 & 420 & 12 & PF & 22.90 & 275 & 695 \\
\hline 32 & PIPE IDENTIFICATION & 12.00 & EA & 6.00 & 72 & 3 & PF & 22.90 & 69 & 161 \\
\hline 33 & AERIAL WORK PLATFOAM & 40.00 & HR & 31.25 & 1250 & 0 & & 0.00 & 0 & 1250 \\
\hline
\end{tabular}


D $\angle$ DLDG 3515

\begin{tabular}{|c|c|c|c|c|c|c|c|c|c|c|}
\hline \multirow{2}{*}{ ITEM } & \multirow{2}{*}{ DESCRIPTION } & \multicolumn{4}{|c|}{ MATERIAL } & \multicolumn{4}{|c|}{ LABOR } & \multirow{2}{*}{$\begin{array}{c}\text { TOTAL COST } \\
M+L\end{array}$} \\
\hline & & oty. & Unit & Unit Pr.l & Total & Mours & $c+2.1$ & | Rate | & Total & \\
\hline 34 & TRUCX \& TRAILER & 16.00 & HR & 45.00 & 720 & 16 & TO & 16.80 & 269 & 989 \\
\hline$\infty+\infty$ & suatotal men & & & & 3062 & 143 & & & 2433 & 5695 \\
\hline 35 & $\begin{array}{l}\text { LOST TIME DUE TO LEVEL C CONDITIONS } \\
\text { (25\%) }\end{array}$ & 240.00 & MR & 0.00 & 0 & 60 & AW & 25.45 & 1527 & 1527 \\
\hline 36 & $\begin{array}{l}\text { LOST TIME DUE TO LEVEL O CONDITIONS } \\
(10 x)\end{array}$ & 151.00 & HR & 0.00 & 0 & 15 & PF & 22.90 & 364 & 366 \\
\hline$\omega t$ & SUBTOTAL "Wo" & & & & 0 & 75 & & & $187 \uparrow$ & 1871 \\
\hline 37 & MOSILIZATION \& DENOSILIZATION & 1.00 & LOT & 378.00 & 378 & 15 & 22 & 22.76 & 361 & 719 \\
\hline TOTAL & DIRECT & & & & 19257 & & & & 1777 & 37030 \\
\hline $\operatorname{TAX}$ & & & & $8.25 \%$ & 1589 & & & & & 1589 \\
\hline SUBTO & & & & & 20846 & & & & $17 \pi$ & 38619 \\
\hline TOTAL & IMOIRECT & & & $20.00 \%$ & $4169 !$ & & & $20.00 \%$ & 3555 & 776 \\
\hline OVER! & AEAD & & & $8.70 x$ & 2176 & & & $8.70 x$ & 1856 & 4032 \\
\hline TOTAL & & & & & 27191 & 781 & & & 23184 & 50375 \\
\hline
\end{tabular}




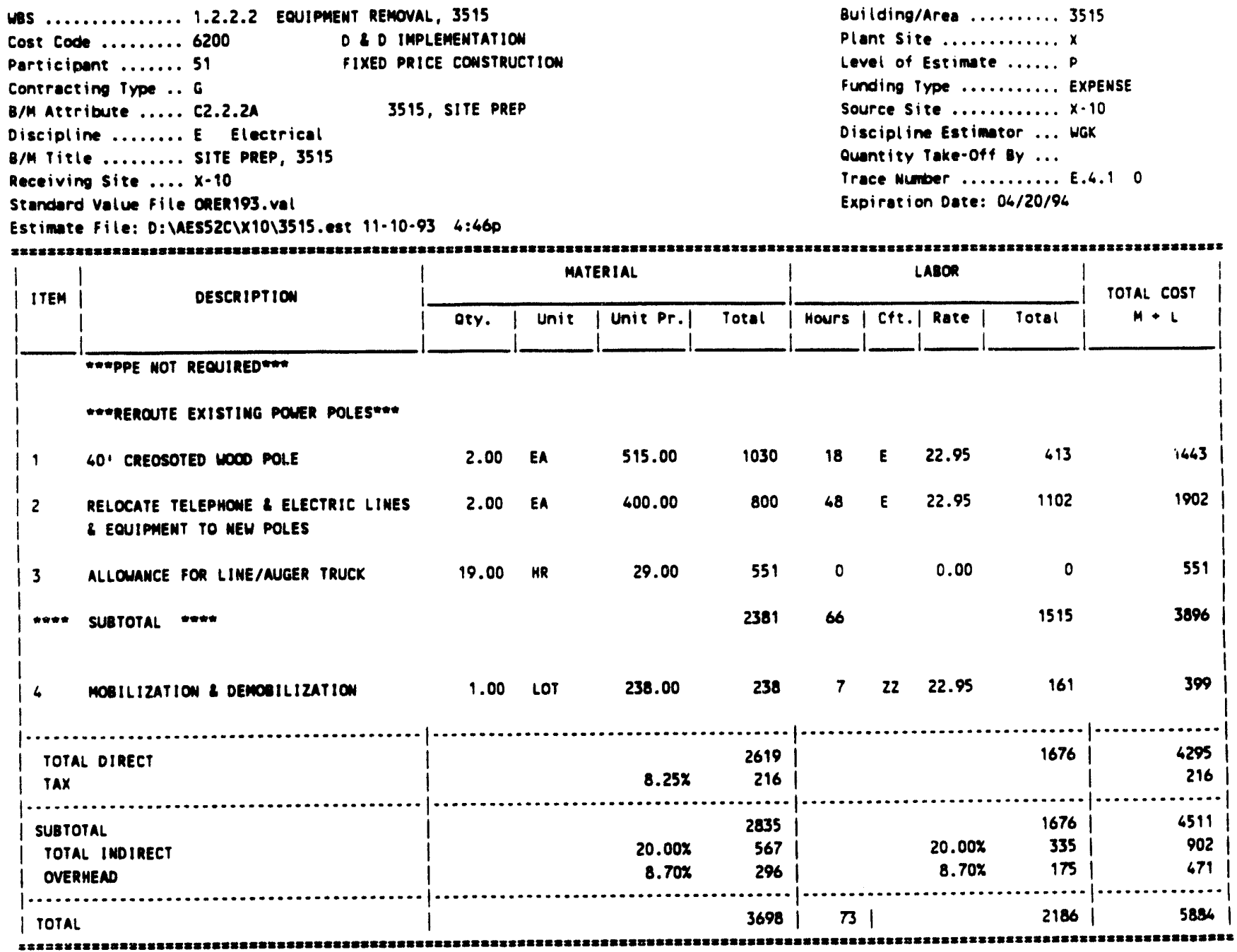




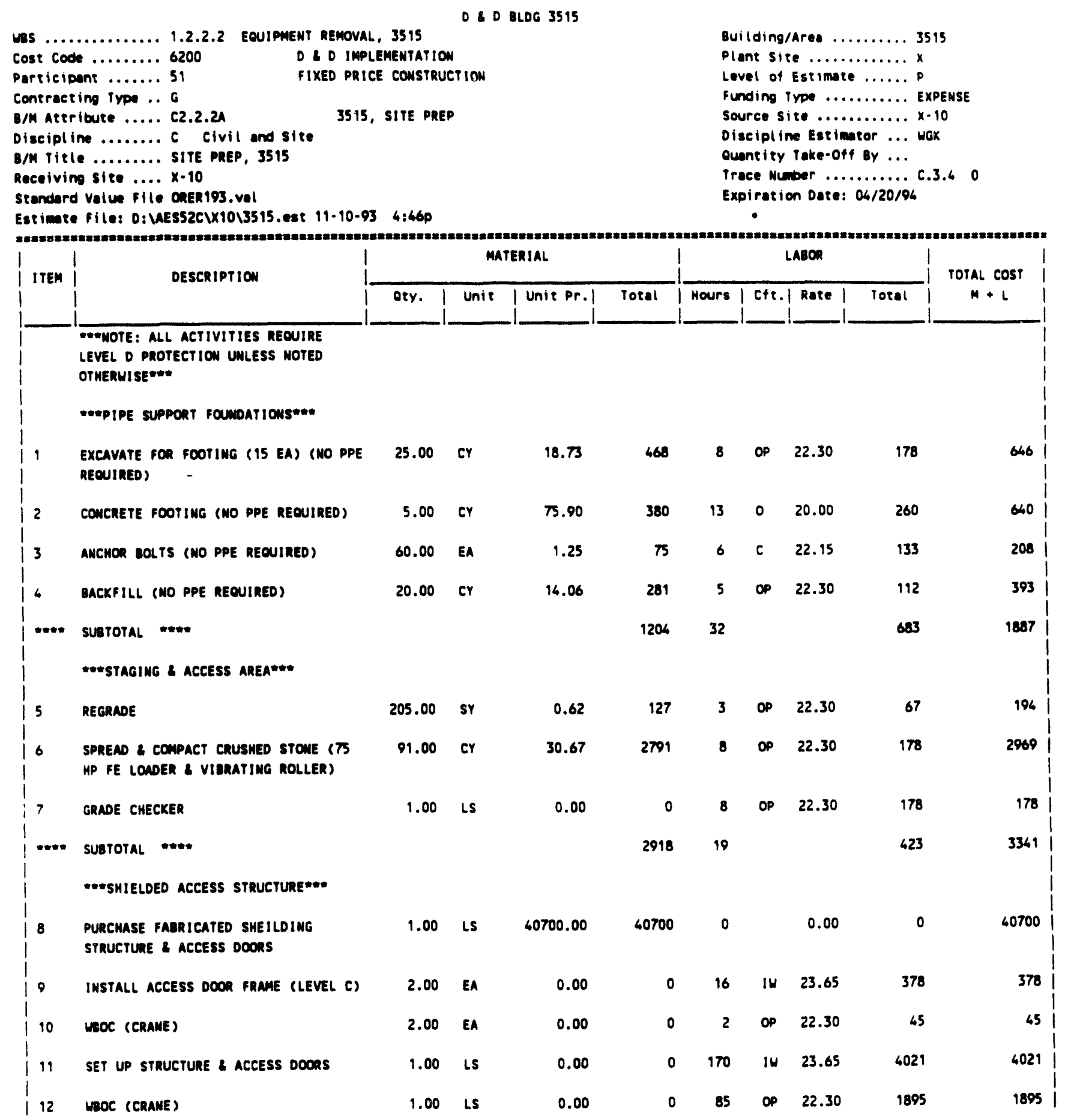


D 4 DLDG 3515

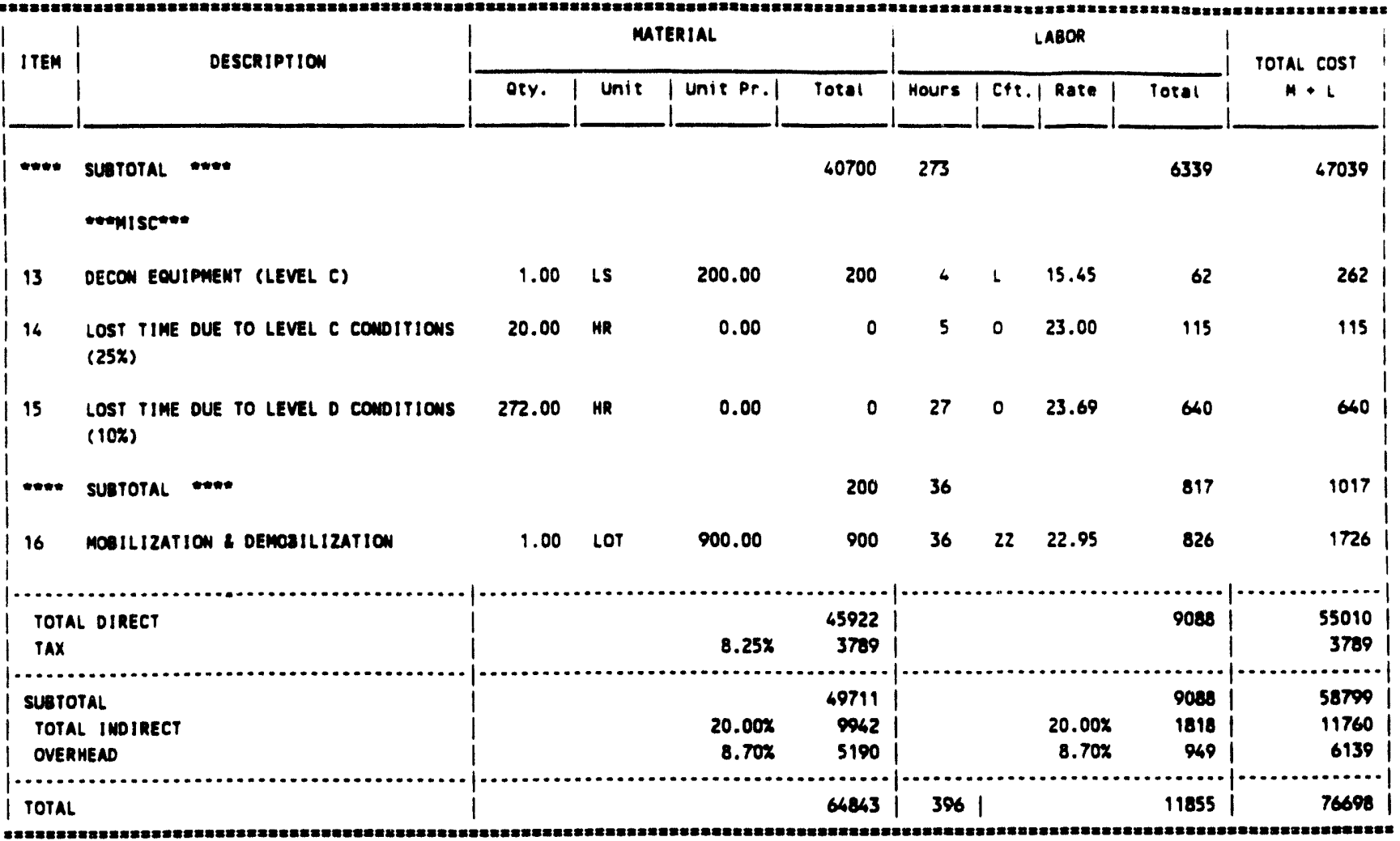


$040 \log 3515$

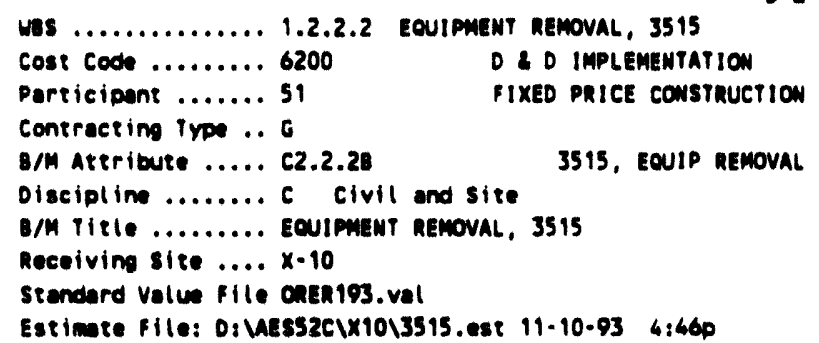


O D ELOG 3515

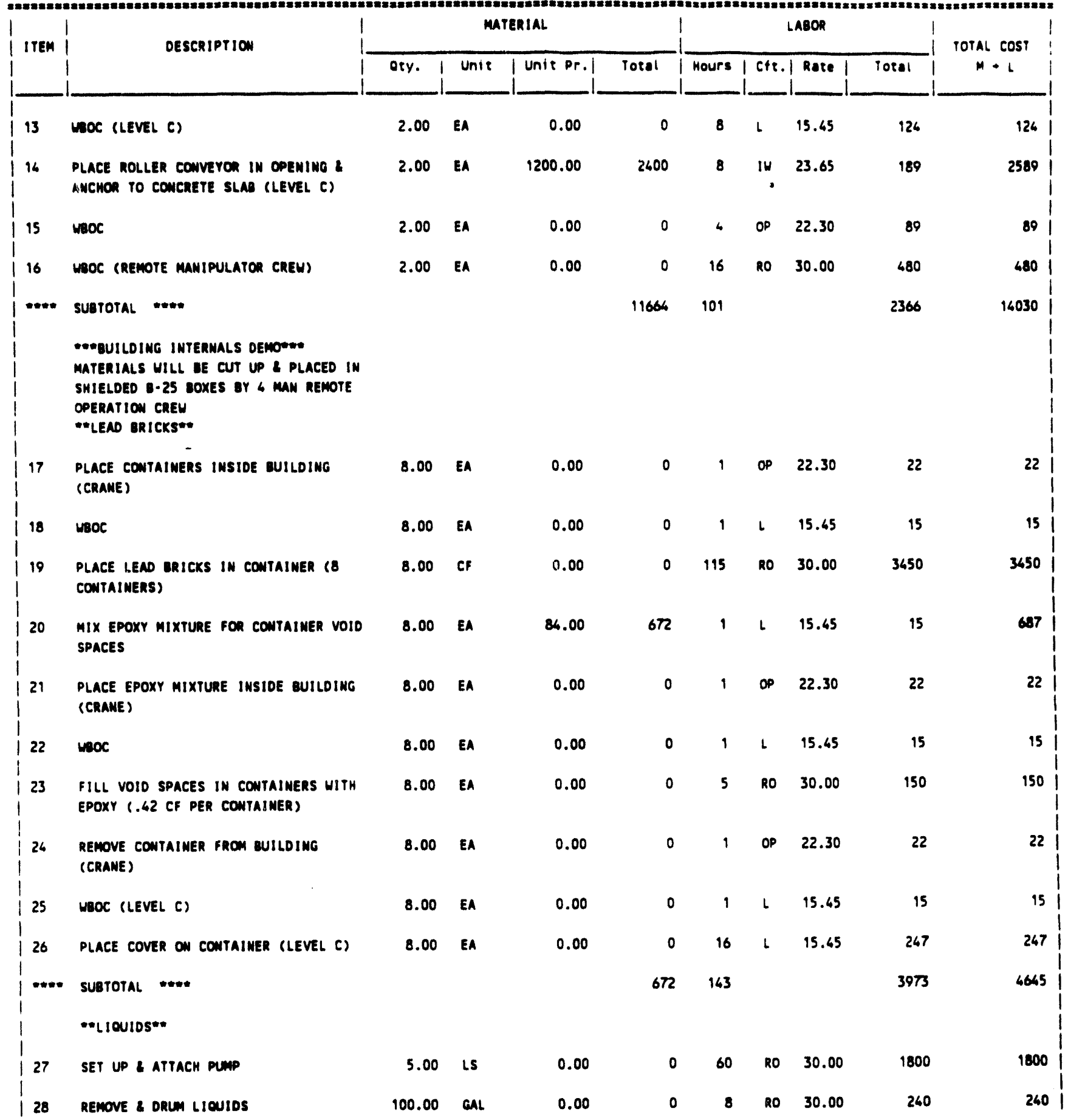


D L D LLO 3515

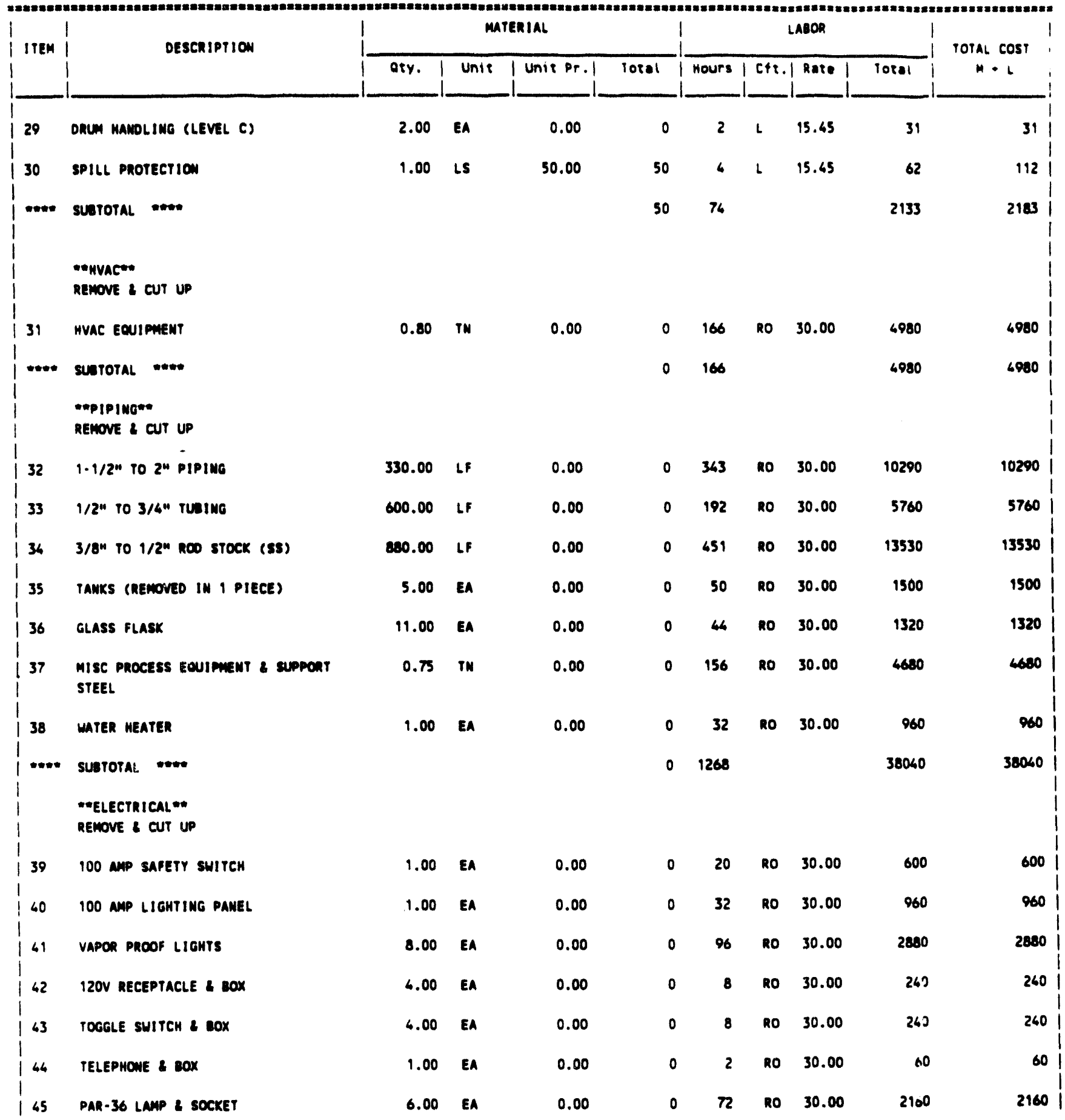


D 2 D BLG 3515

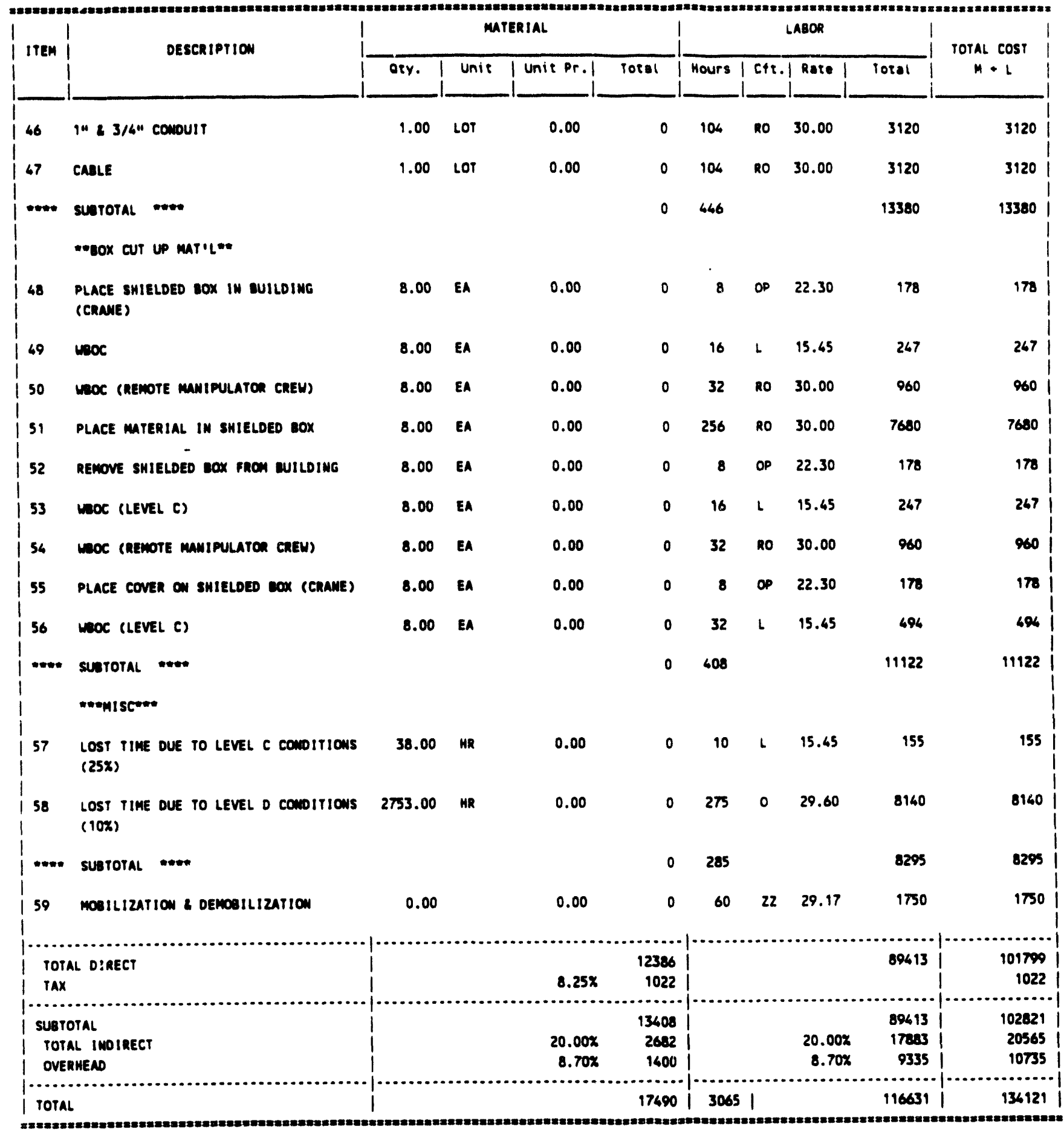




\section{L D LOG 3515}

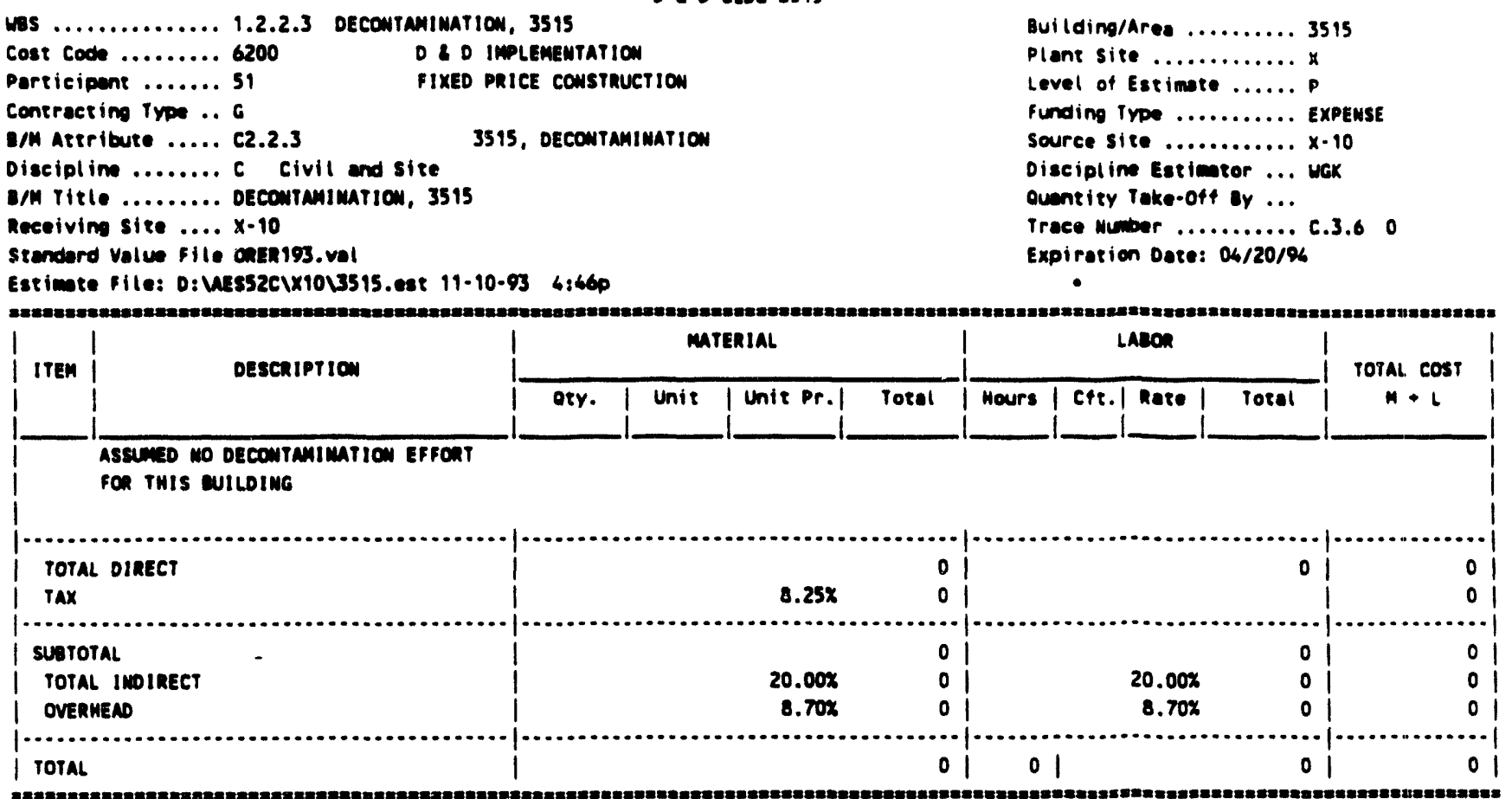


D 20 BLDG 3595

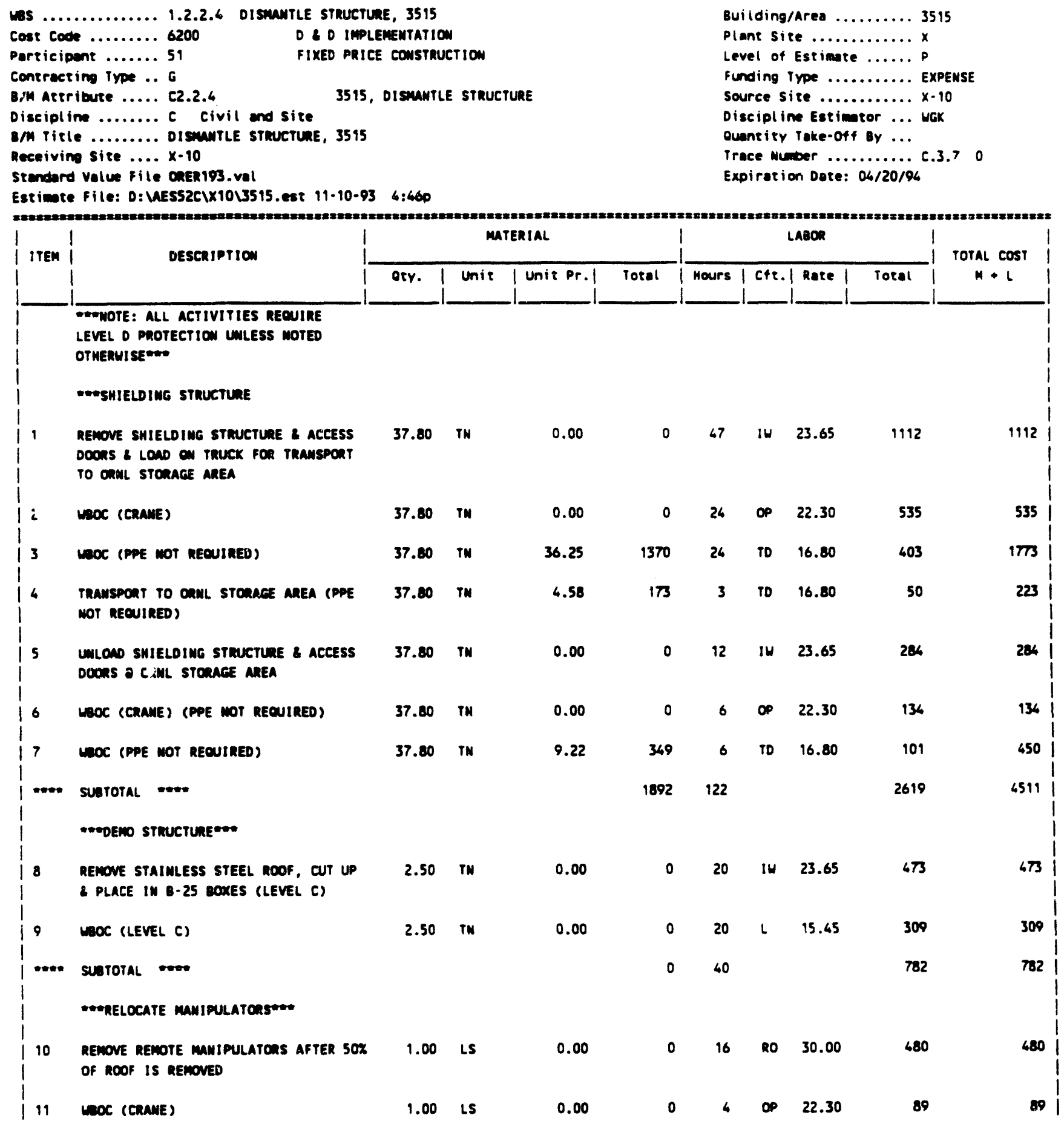


D 5 D BLDG 3515

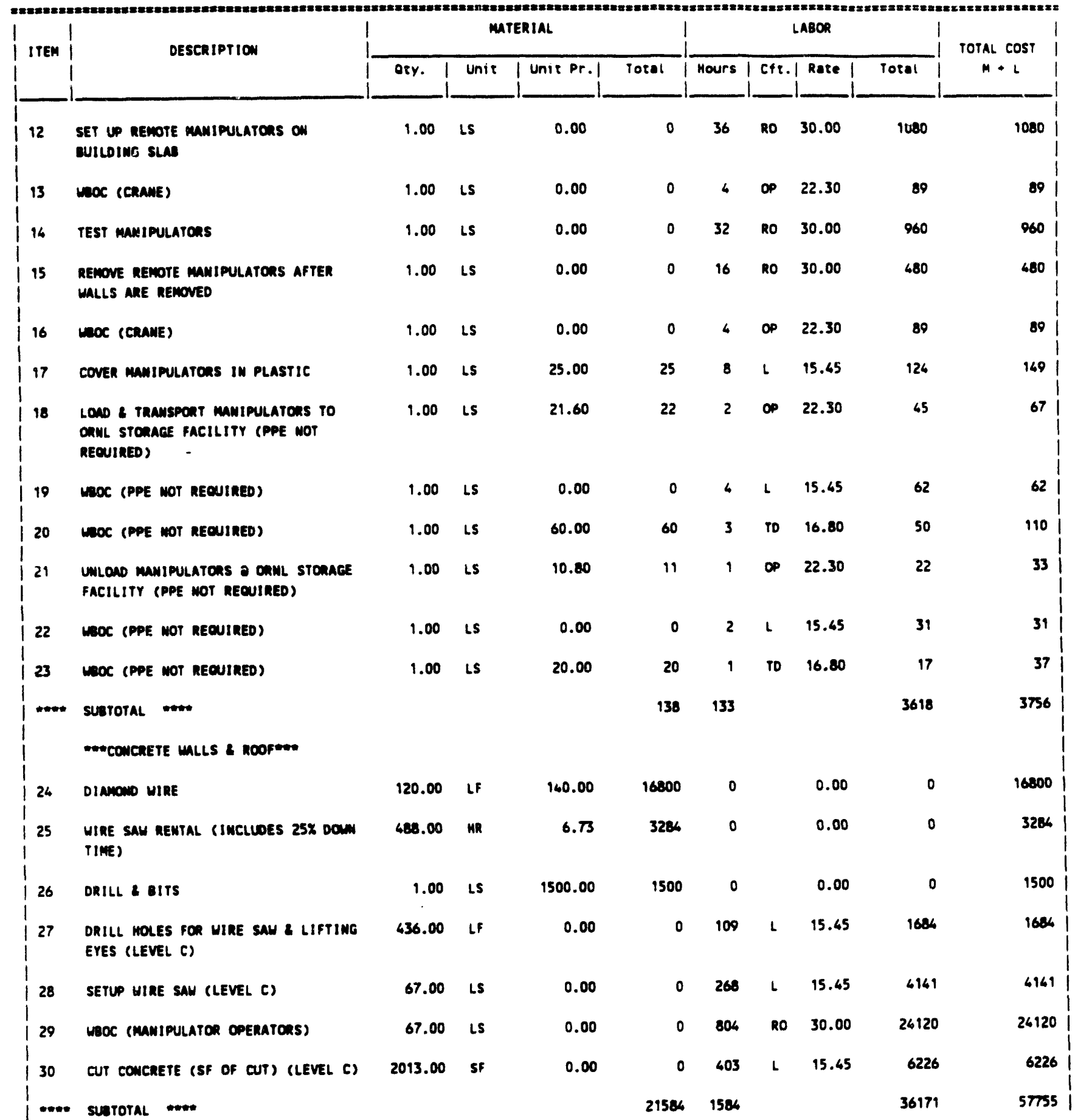


D D BLOG 3515

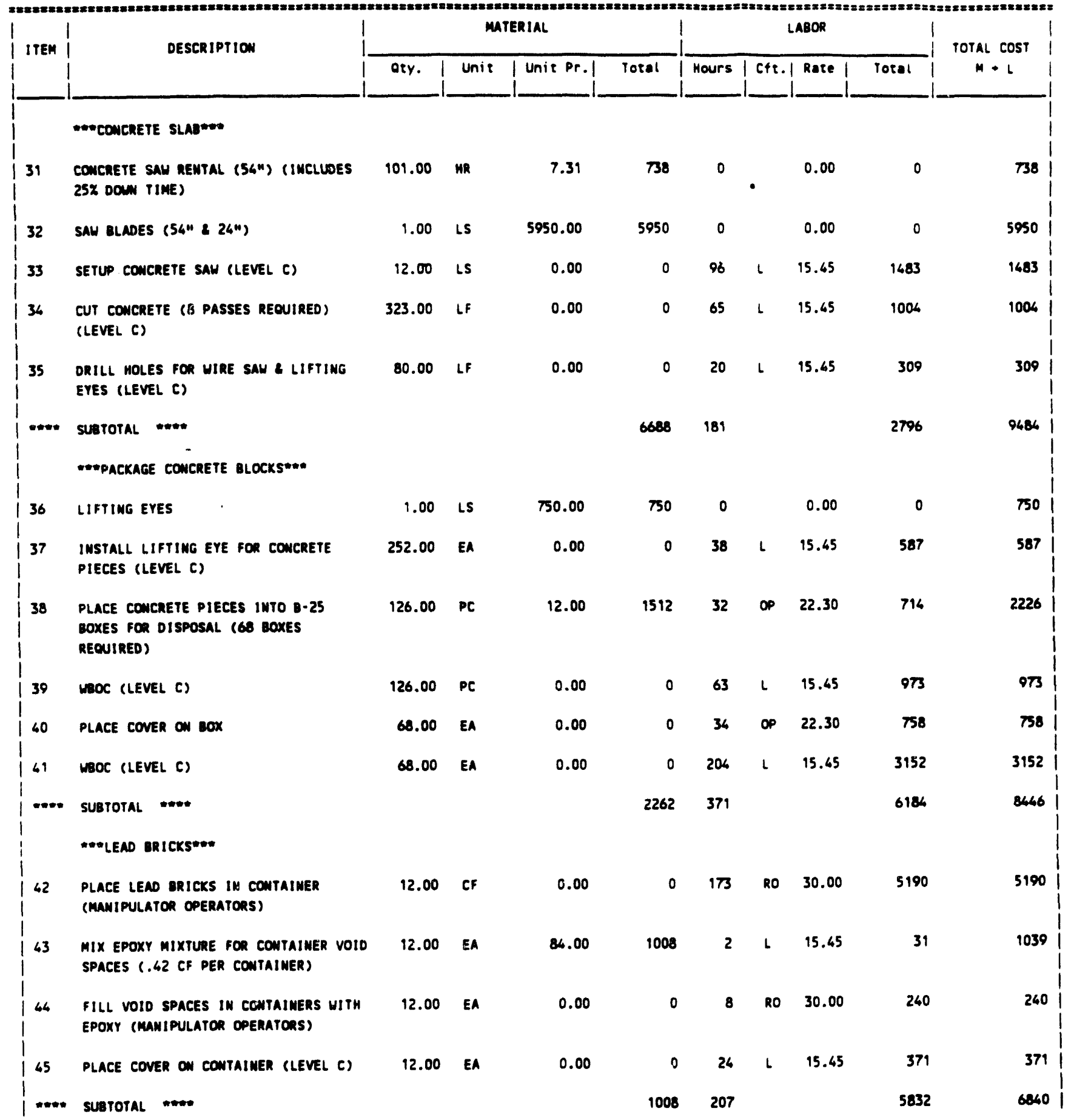


D 2 D ELDG 3515

\begin{tabular}{|c|c|c|c|c|c|c|c|c|c|c|}
\hline \multirow{2}{*}{ ITEM } & \multirow{2}{*}{ DESCRIPTION } & \multicolumn{4}{|c|}{ MATERIAL } & \multicolumn{4}{|c|}{ LABOR } & \multirow{2}{*}{$\begin{array}{c}\text { TOTAL } \cos T \\
M+L\end{array}$} \\
\hline & & Dty. & Unie & Unit Pr.l & Total & Hours & $c+t .1$ & Rate | & Total & \\
\hline & montsents & & & & & & & & & \\
\hline 46 & $\begin{array}{l}\text { LOST TIME DUE TO LEVEL C COMDITIONS } \\
\text { (25\%) }\end{array}$ & 1330.00 & HR & 0.00 & 0 & 333 & 0 & 15.83 & 5279 & 5279 \\
\hline 47 & $\begin{array}{l}\text { LOST TIME OUE TO LEVEL D CONDITIONS } \\
(10 x)\end{array}$ & 1256.00 & NR & 0.00 & 0 & 126 & 0 & 29.71 & 3743 & 3743 \\
\hline 48 & MOSILIZATION \& DEMOSILIZATIOH & 1.00 & LOT & 671.00 & 679 & 93 & 22 & 21.64 & 2012 & 2683 \\
\hline TOTAL & L DIRECT & & & & 34243 & & & & 69028 & 103271 \\
\hline $\operatorname{tax}$ & & & & $8.25 \%$ & 2825 & & & & & 2825 \\
\hline SUBTO & & & & & 37060 & & & & 69028 & 106096 \\
\hline TOTAL & L IMOIRECT & & & $20.00 \%$ & 7416 & & & $20.00 x$ & 13806 & 21220 \\
\hline OVERI & MEAD & & & $8.70 \%$ & 3870 & & & $8.70 x$ & 7207 & 1107 \\
\hline TOTAL & & & & & 48352 & 3190 & & & 90041 & 138393 \\
\hline
\end{tabular}


D I D BLOG 3515

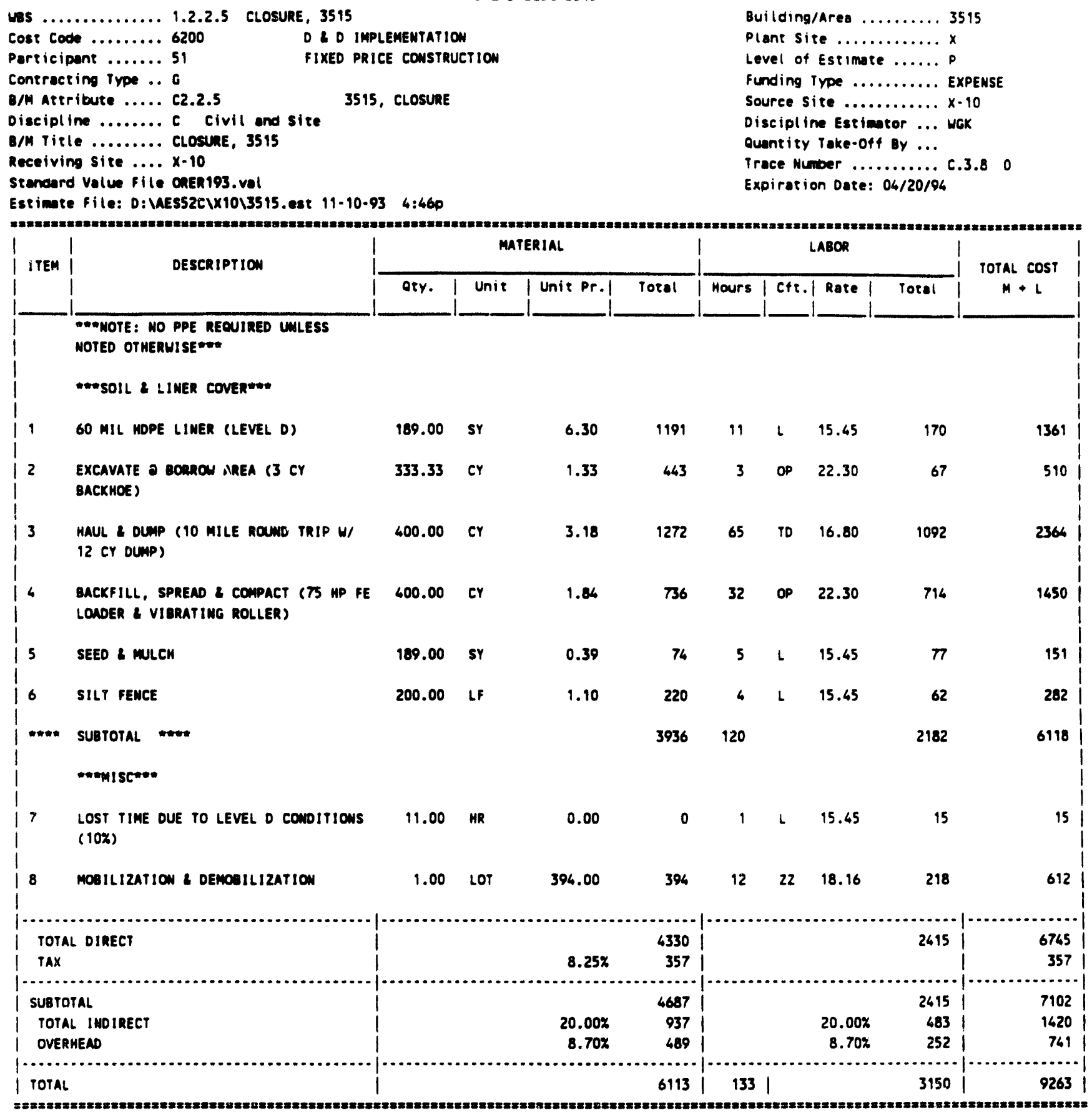




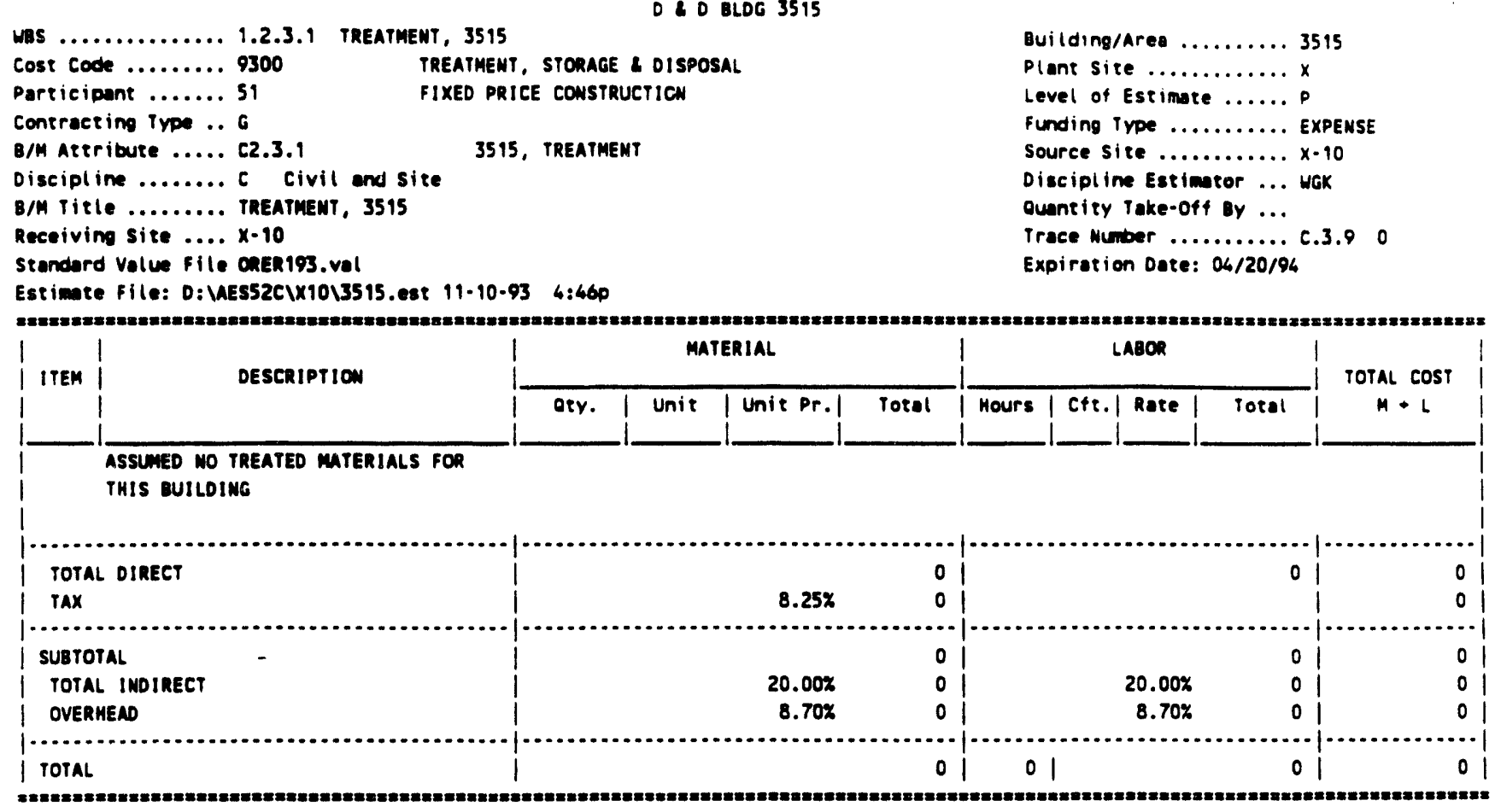


D \& D BLDG 3515

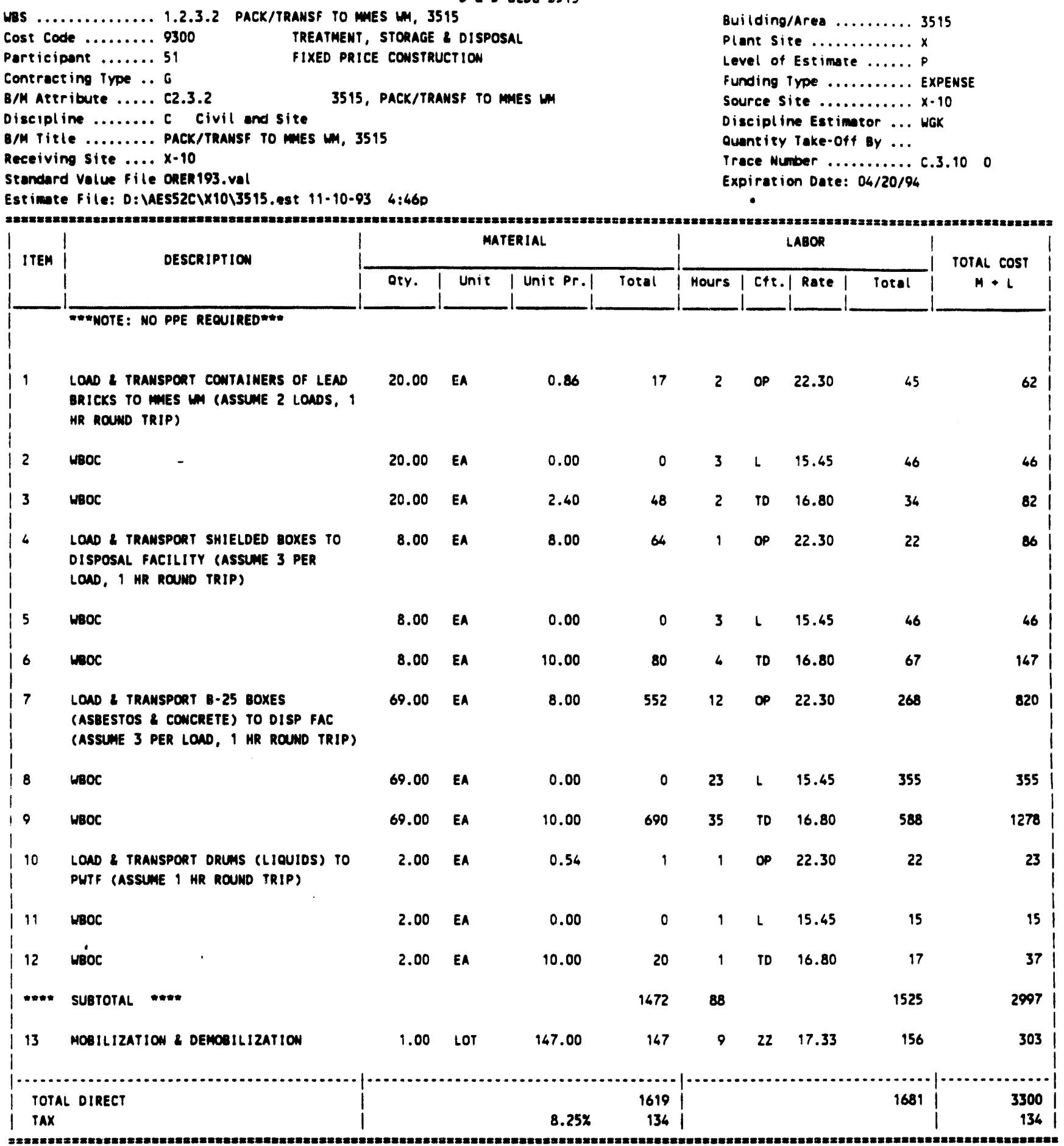


DE D BLDG 3515

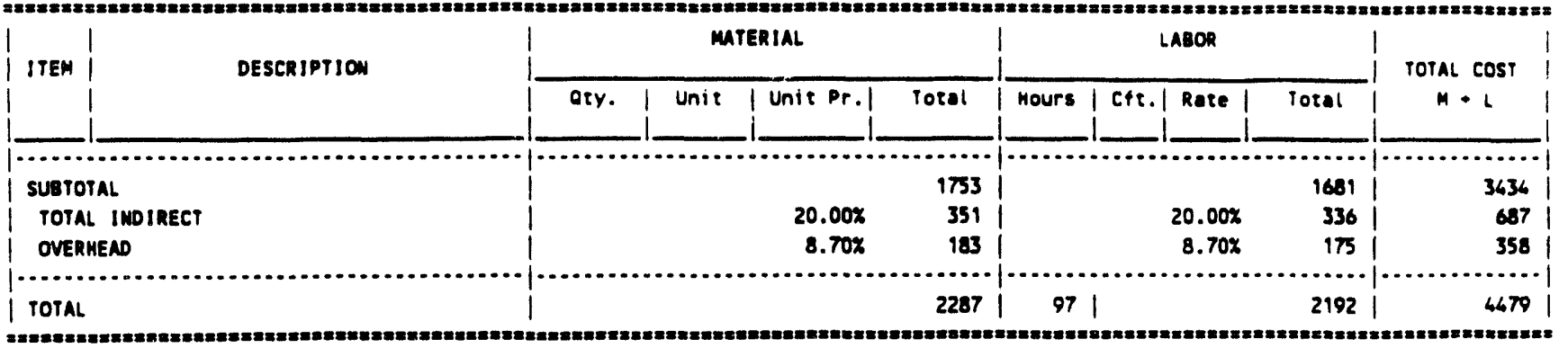

\section{C-39}


D \& D OLDE 3515

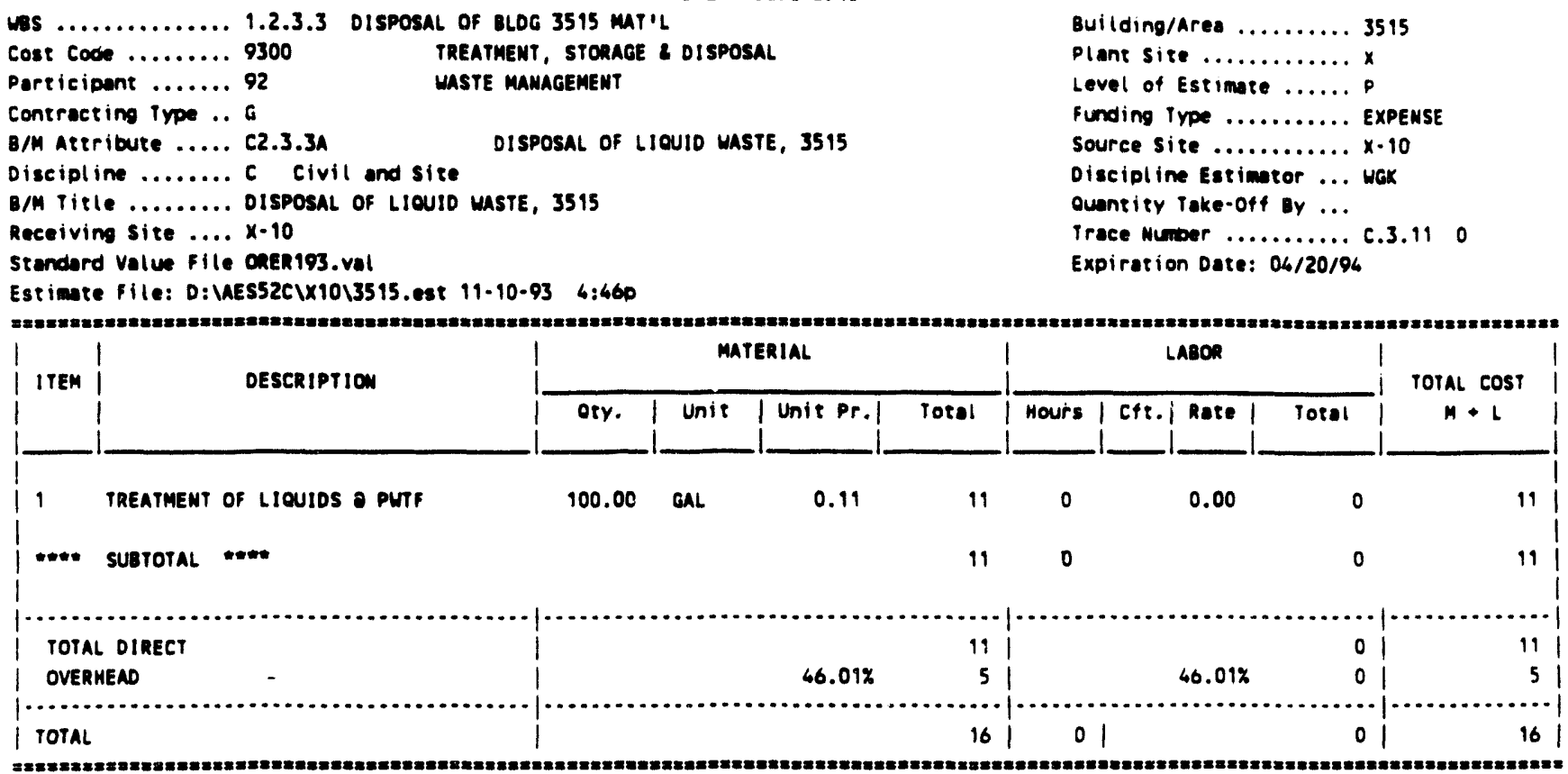


D L DLOG 3515

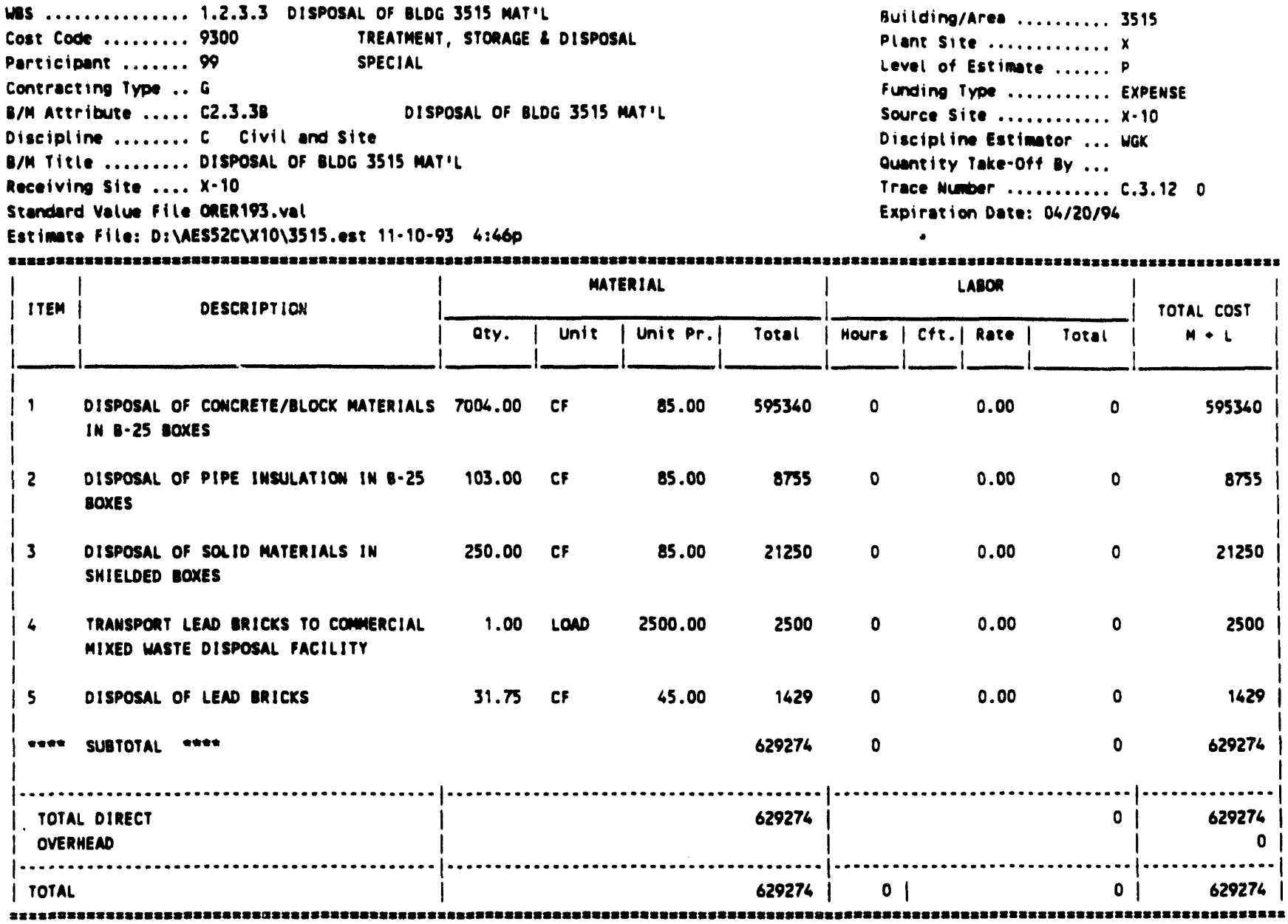




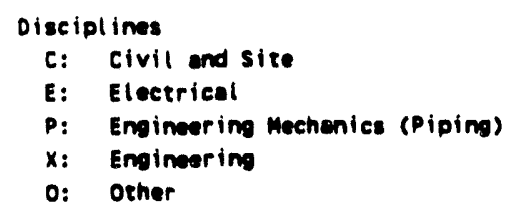

COST SUmuRY

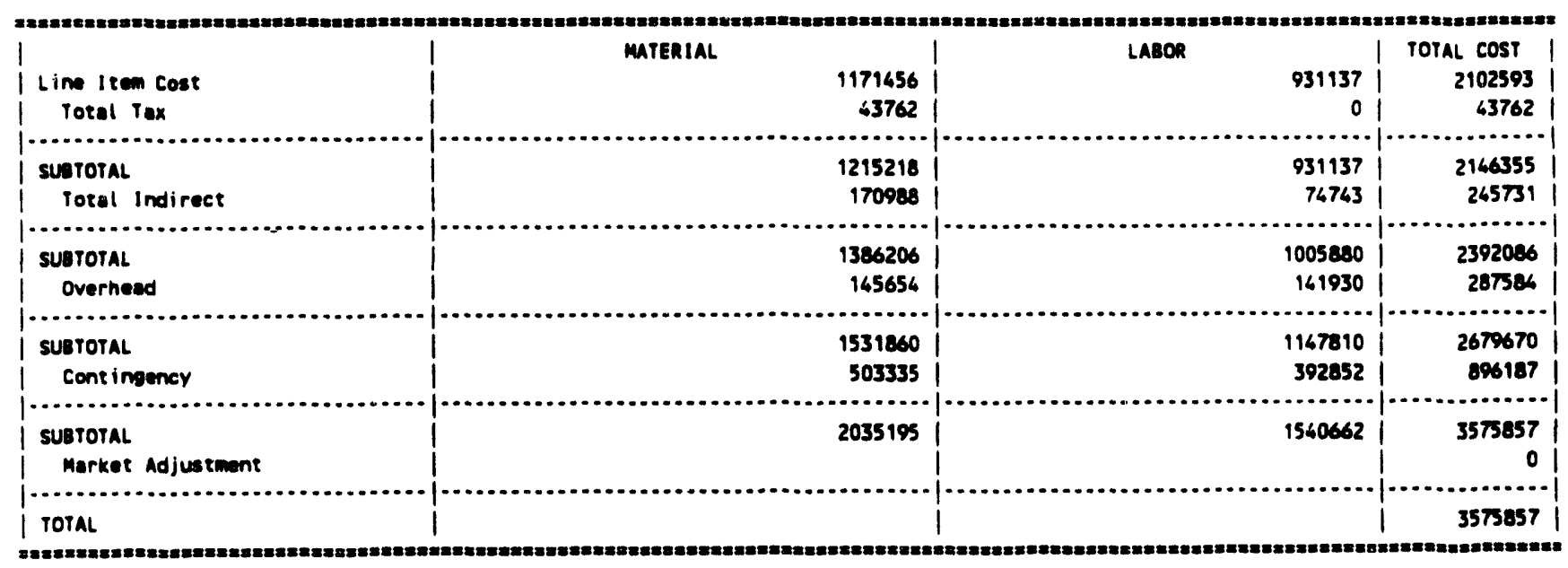


Appendix D.

Cost Estimate for

Partial Dismantlement of Building 3515 
SUmmar REPORT

Project Numer: 930031.1

D 2 D ILOG 3515, PARTIAL

Project Eso Numer.......

Revision Nuber.........

Lest Update............11/10/93

Sort Order

1. wes

2. Participant

Approved by:

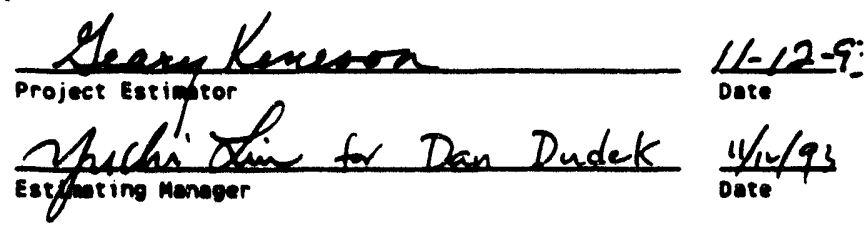

AES Version $5.2 \mathrm{C}$

Bose Fiscal Vear/ourter: 93/4

STAMDARO VALUE: COERT193.val EXPIRES: $04 / 20 / 94$

ESTIMATE FILE: D: WAES52CIX10l3515P.eat $91 / 10 / 93$

SCMEDULE FILE: $3515 P$

REPORT FILE : D:WES52C1X1013515PS. OUT 11/10/93 16:54:57 
O 20 oldo 3515, PARTIAL

SUMURY REPORT

$\$ 1=\$ 1000$

$11 / 10 / 93$

Arreneed oy: ws / Porticipant

1.2.1.9 PROJECT IMTECaATION, 3515

49 mes project senvices

90 ER OIVIsion

TOTAL PROJECT InTECAATION. 3515

1.2.1.2 TITLE I \& 11 ENGIMEERIMG, 3515

18 A-E TITLE 1 \& 11 ENCA.

48 mes A-E SUPpon?

TOTAL TITLE I I II EMGIMEERING, 3515

1.2.1.3 coust nemit a gurpent, 3515

66 M.F INDIRECTS ON FP

67 m-F DInects on EP

TOTAL CONST MEmit \& SAPPONT, 3515

1.2.1.4 TITLE 111 ENGIMEERIMG, 3515

13 WES TITLE III ENER.

19 A-E TITLE III ENCQ.

totAl TITLE III EMGIMEERING, 3515

1.2.2 BUILDIMG 3515 D \& D, PARTIAL

41 MES FIELD MAINTEMANCE

51 FIXED PRICE COUSTRUCTIO

TOTAL EUILDIMG 3515 D \& D, PARTIAL

1.2.2.1 INITIAL CMARACTERIzATION, 3515 51 FIXED PRICE COASTRUCTIOO

TOTAL INITIAL CHARACTERIZATION, 3515

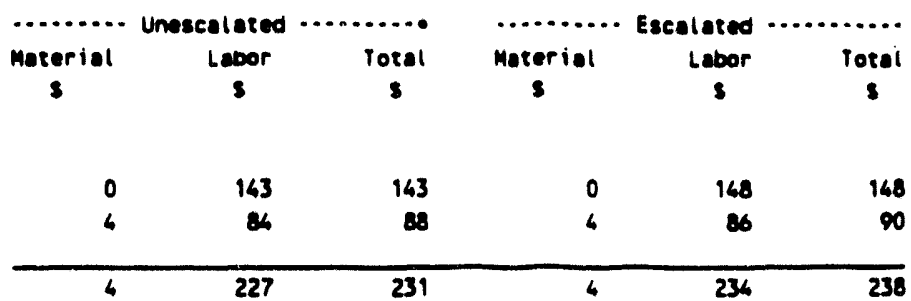

\begin{tabular}{rrrrrr}
0 & 132 & 132 & 0 & 133 & 133 \\
0 & 66 & 66 & 0 & 67 & 67 \\
\hline 0 & 196 & 198 & 0 & 200 & 200
\end{tabular}

\begin{tabular}{rrrrrr}
115 & 0 & 115 & 120 & 0 & 120 \\
3 & 236 & 237 & 3 & 263 & 266 \\
\hline 118 & 236 & 352 & 123 & 263 & 366
\end{tabular}

\begin{tabular}{rrrrrr}
9 & 161 & 170 & 10 & 169 & 179 \\
0 & 43 & 43 & 0 & 45 & 45 \\
\hline 9 & 206 & 213 & 10 & 214 & 226
\end{tabular}

\begin{tabular}{rrrrrr}
336 & 1 & 335 & 350 & 1 & 351 \\
306 & 51 & 357 & 322 & 53 & 375 \\
\hline 640 & 52 & 692 & 672 & 56 & 726
\end{tabular}

\begin{tabular}{llllll}
6 & 24 & 30 & 6 & 25 & 31 \\
\hline 6 & 26 & 30 & 6 & 25 & 31
\end{tabular}

D-4 
D D OLDG 3515, PARTIAL

SUMmMRY REPORT

$$
s 1=\$ 1000
$$

$11 / 10 / 93$

\section{Arranged by: ws / Participant}

1.2.2.2 ECUIPWENT REMOVAL, 3515 51 FIXED PRICE construction

TOTAL EOUIPAENT REMOVAL, 3515

1.2.2.3 DECONTAMIMATION, 3515 51 FIKED PRICE CONSTRUCTION

TOTAL DECONTAMIMATION, 3515

1.2.2.6 DISHANTLE STRUCTUNE, 3515 51 FIXED PRICE COASTRUCTION

TOTAL DIEnNTLE STRUCTURE, 3515

1.2.2.5 ClOSURE, 3515

51 FIXED PRICE CONSTRUCTION

Tatal Closune, 3515

1.2.3.1 TREATMENT, 3515

51 FIXED PRICE COASTRUCTIOU

TOTAL TREATMENT, 3515

1.2.3.2 PACK/TRAMSF TO MESS IN, 3515 51 FIXED PRICE COAstruetion

TOTAL PACK/TRAMSF TO mes MA, 3515

1.2.3.3 DISPOSAL OF BLDG 3515 MATIL 92 UASTE maMACEMENT

9 SPECIRL

TOTAL DISPOSAL OF BLDG 3515 mAT'L

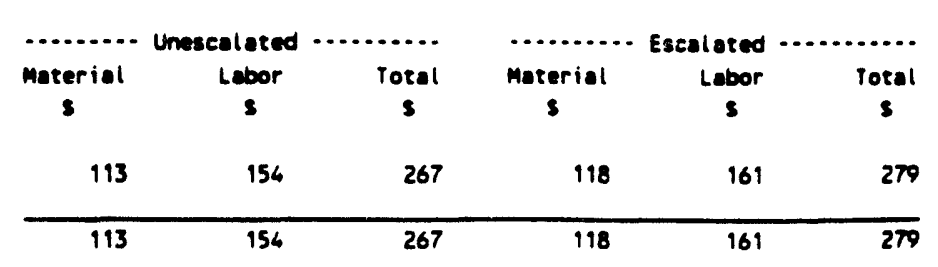

\begin{tabular}{llllll}
22 & 23 & 45 & 23 & 26 & 47 \\
\hline 22 & 23 & 45 & 23 & 26 & 47
\end{tabular}

\begin{tabular}{llllll}
38 & 85 & 123 & 40 & 89 & 129 \\
\hline 38 & 85 & 123 & 40 & 89 & 129
\end{tabular}

\begin{tabular}{llllll}
6 & 3 & 9 & 6 & 3 & 9 \\
\hline 6 & 3 & 9 & 6 & 3 & 9
\end{tabular}

\begin{tabular}{llllll}
43 & 1 & 46 & 45 & 1 & 46 \\
\hline 43 & 1 & 46 & 45 & 1 & 46
\end{tabular}

\begin{tabular}{llllll}
2 & 2 & 4 & 2 & 2 & 6 \\
\hline 2 & 2 & 4 & 2 & 2 & 4
\end{tabular}

\begin{tabular}{rrrrrr}
19 & 0 & 19 & 20 & 0 & 20 \\
467 & 0 & 467 & 491 & 0 & 491 \\
\hline 486 & 0 & 486 & 211 & 0 & 511
\end{tabular}

\section{D-5}




\title{
D 2 D ElDg 3515, PARTIAL \\ SUMURY REPORT
}

\author{
$\$ 1=\$ 1000$ \\ $11 / 10 / 93$
}

Arranged By: WaS / Participant

SUB - TOTAL

CONTIMGENCY

GRAMD TOTAL

\begin{tabular}{|c|c|c|c|c|c|}
\hline $\begin{array}{c}\text { Material } \\
\$\end{array}$ & $\begin{array}{c}\text { Labor } \\
5\end{array}$ & $\begin{array}{c}\text { Total } \\
5\end{array}$ & $\begin{array}{c}\text { Material } \\
\text { s }\end{array}$ & $\begin{array}{c}\text { Labor } \\
s\end{array}$ & $\begin{array}{c}\text { Totel } \\
S\end{array}$ \\
\hline 1487 & 1207 & 2694 & 1560 & 1250 & 2810 \\
\hline 492 & 616 & 906 & 517 & 430 & 967 \\
\hline 1979 & 1621 & 3600 & 2077 & 1680 & 3757 \\
\hline
\end{tabular}

D-6 
DETALL REPORT

Project Mumber: 930031.1

D E BLDG 3515, PARTIAL

\author{
Project ESO Muber...... \\ Revision Number......... \\ Lest Updote.............11/10/93
}

Sort Order

1. Wns

2. Participant

3. B/M Attribute

Approved by:

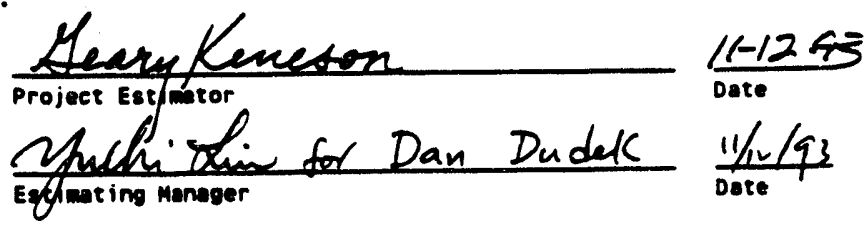

AES Version 5.26

Bose fiscal Year/ouarter: $93 / 6$

STACDARO VALUE: ORER193.val EXPIRES: $04 / 20 / 94$

ESTIMATE FILE: D: WES52CIX1013515P.est 11/10/93

SCHEDULE FILE: 3515P

REPORT FILE : D:WES52CIX1013515P0.out 11/10/93 16:49:38 
Discipl ine ........ $\times$ Engineering

o/M Title .......... mes project senvices

Receiving site ..... $x-10$

Standard value file OnER193.val

Estimate File: D:IAES52CIX1013515P.est $11-10-93 \quad 4: 45 p$

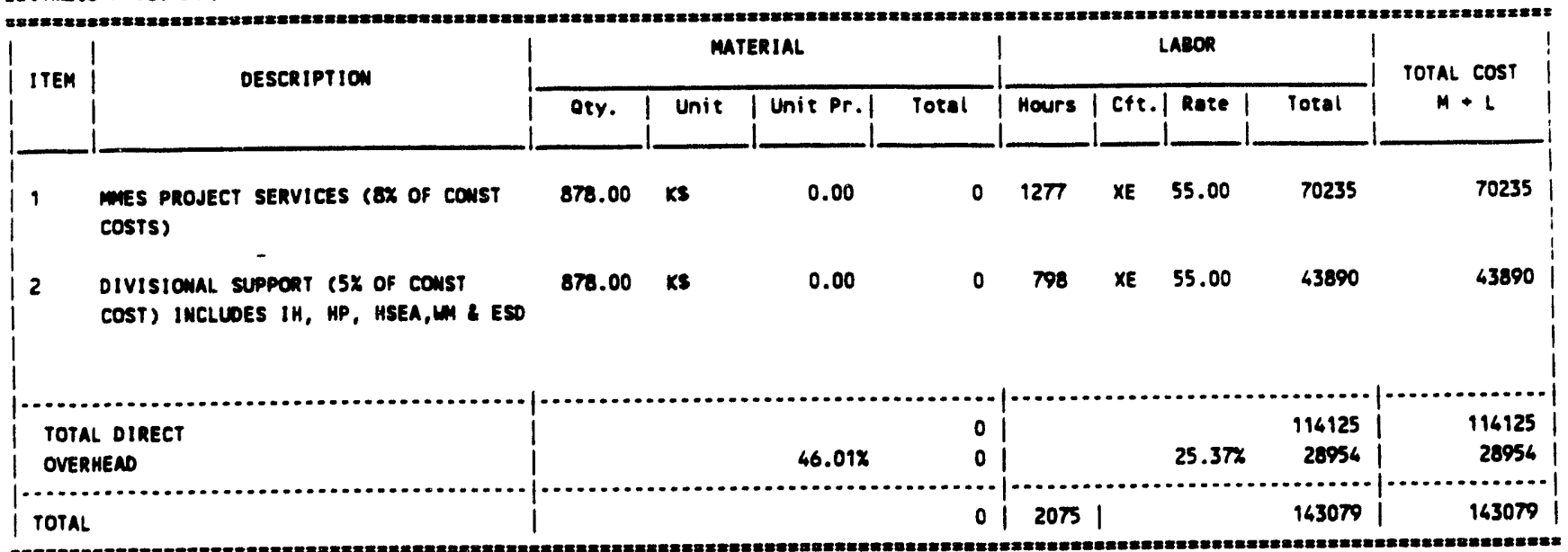

\section{D-8}


D \& BLDG 3515, PARTIAL

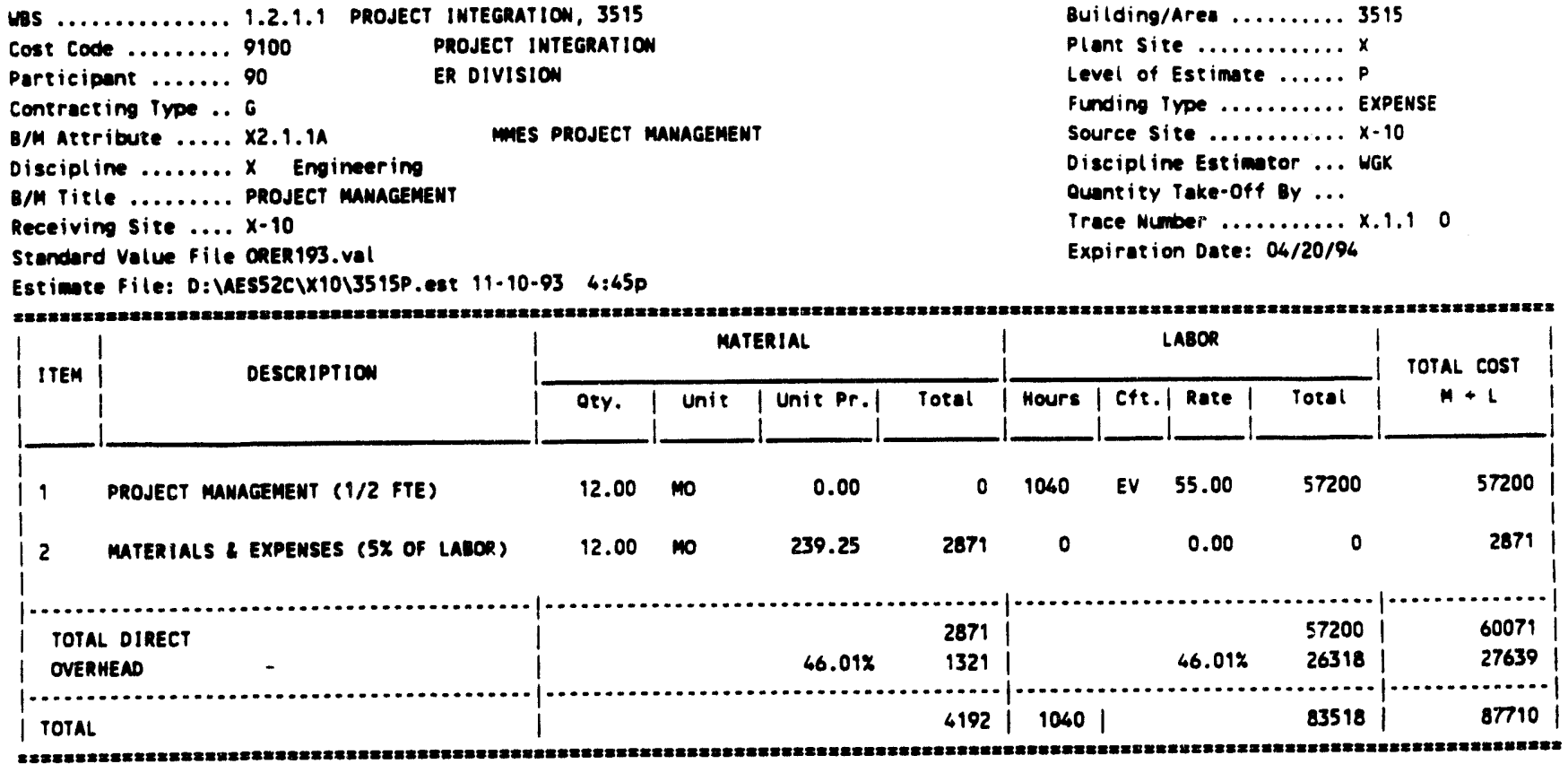


D 20 DLDG 3515, PARTIAL

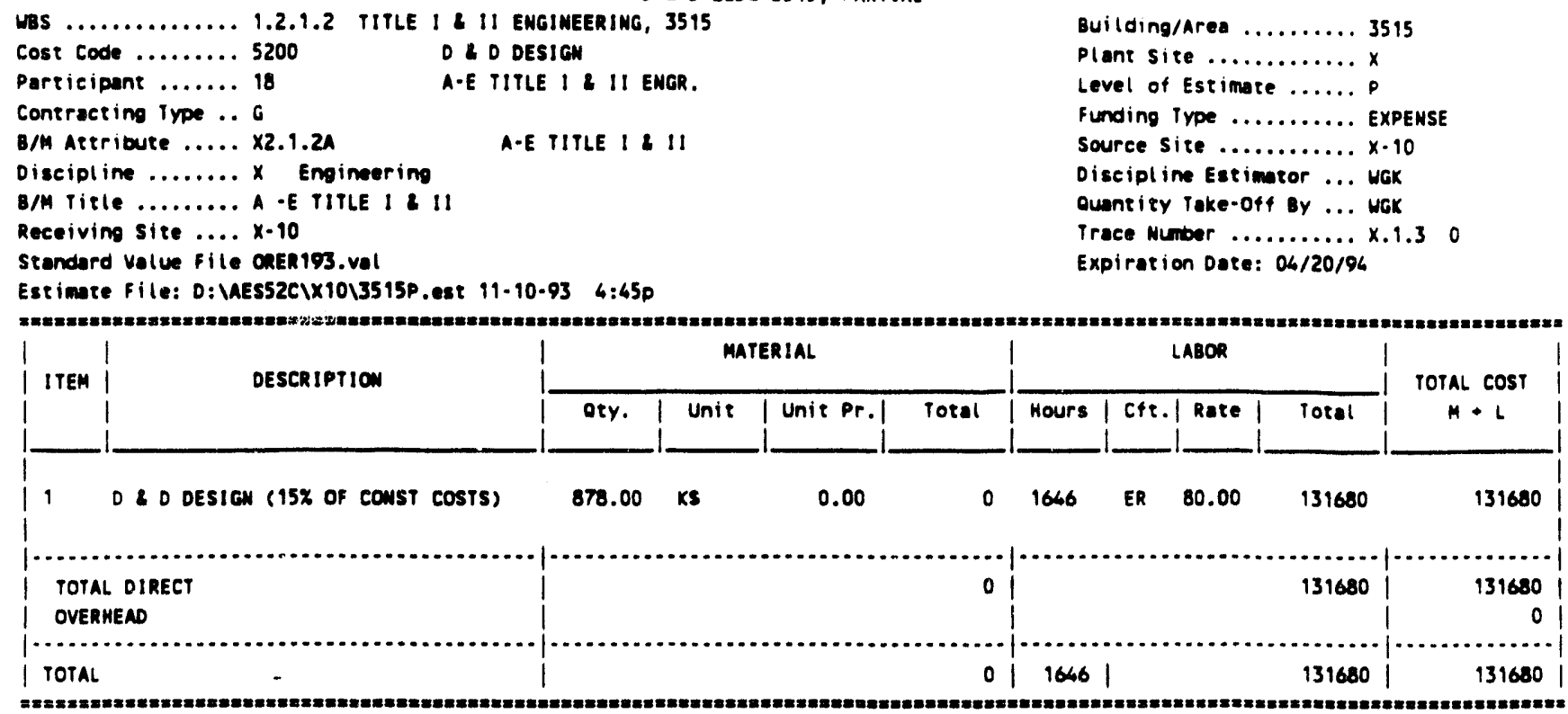


D O BLDG 3515, PARTIAL

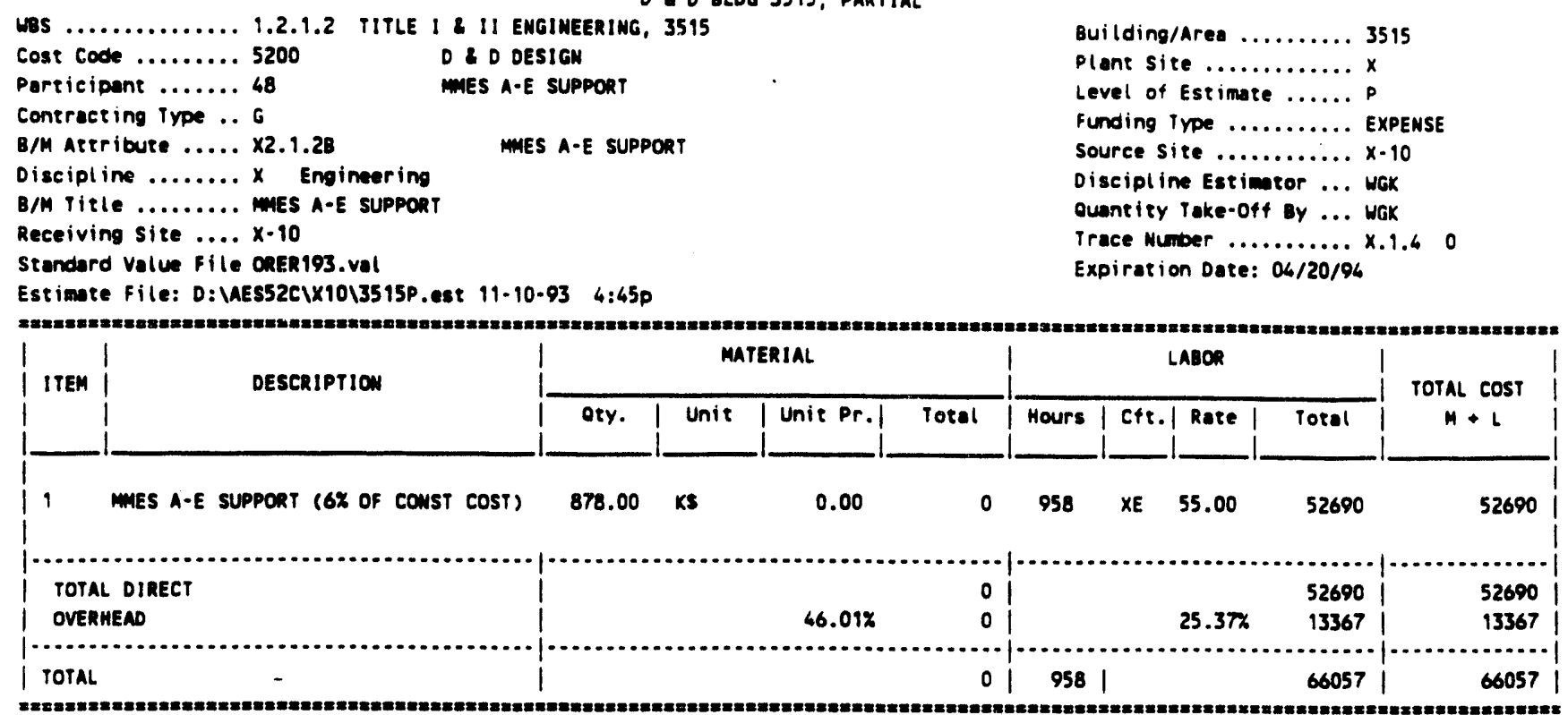

\section{D-11}


DE D BLDG 3515, PARTIAL

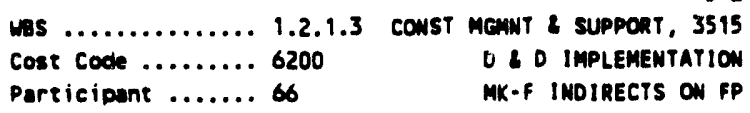

\begin{tabular}{|c|c|c|c|c|c|c|c|c|c|c|}
\hline \multirow{2}{*}{ ITEM } & \multirow{2}{*}{ DESCRIPTIOW } & \multicolumn{4}{|c|}{ MATERIAL } & \multicolumn{4}{|c|}{ LABOR } & \multirow{2}{*}{$\begin{array}{c}\text { TOTAL COST } \\
M+L\end{array}$} \\
\hline & & oty. & Unit & Unit Pr.| & Total & Hours & eft.l & Rate I & Total & \\
\hline 1 & MK-F INDIRECTS ON FP (12\% OF FP) & 878.00 & xs & 120.00 & 105360 & 0 & & 0.00 & 0 & 105360 \\
\hline $\begin{array}{l}\text { TOTA } \\
\text { OVER }\end{array}$ & $\begin{array}{l}\text { LINDIRECT } \\
\text { MEAD }\end{array}$ & & & 8.70x & $\begin{array}{r}105360 \\
9166\end{array}$ & & & $8.70 \%$ & $\begin{array}{l}0 \\
0\end{array}$ & $\begin{array}{r}105360 \\
9166\end{array}$ \\
\hline TOTAL & - & & & & 114526 & 0 & & & 0 & 116526 \\
\hline
\end{tabular}

Building/ared .......... 3515

Plant site ............. $x$

Level of Estimate ....... p

funding iype ........... EXPEKSE

Source site ........... $\times 10$

Discipline Estimtor ... WGK

Quantity Take-off By ... WGK

Trace Mumber .......... 0.2.1 O

Expiration Date: $04 / 20 / 94$ 
O \& D BLOG 3515, PARTIAL

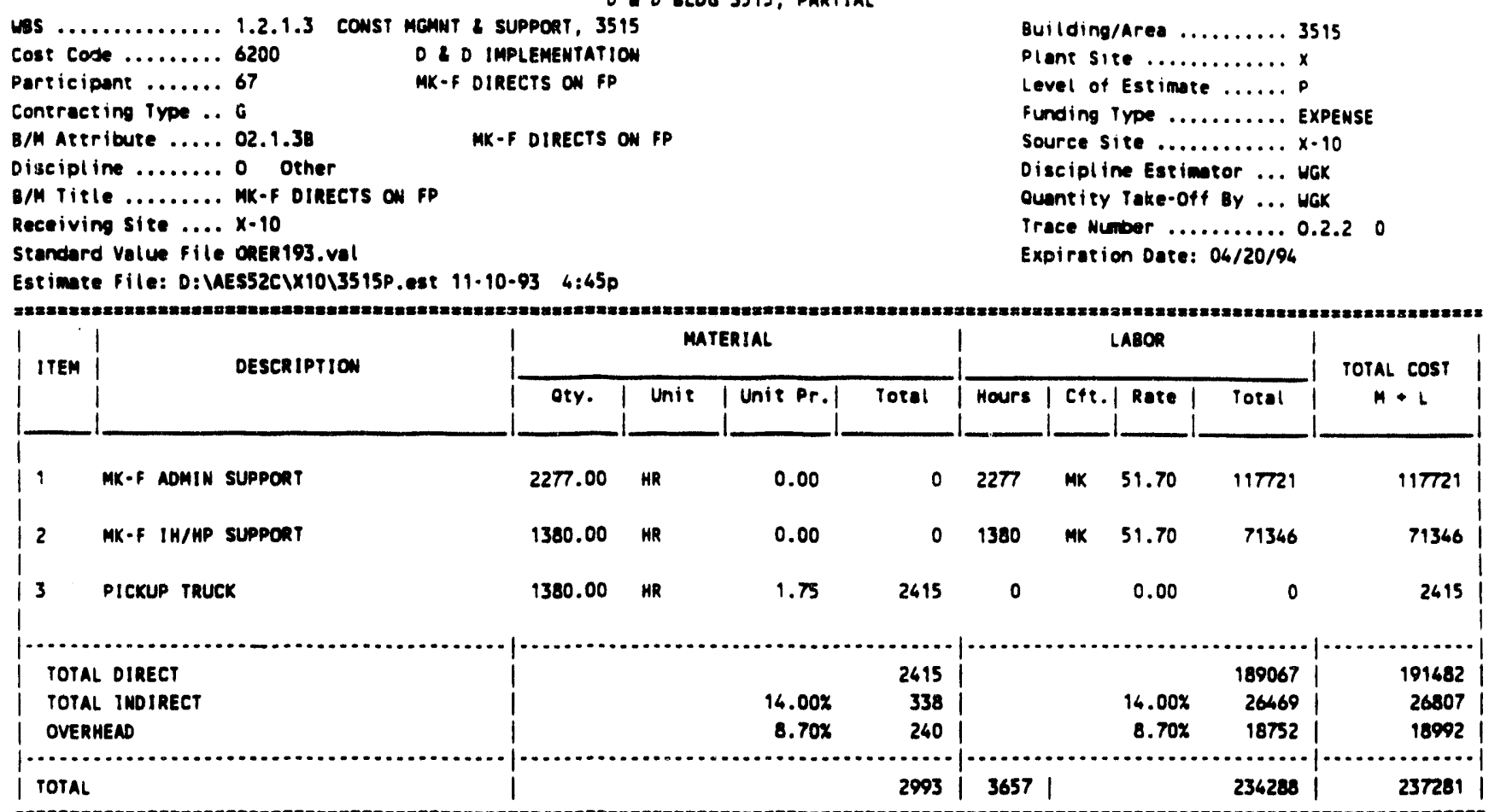


D I D LLO 3515, PARTIAL

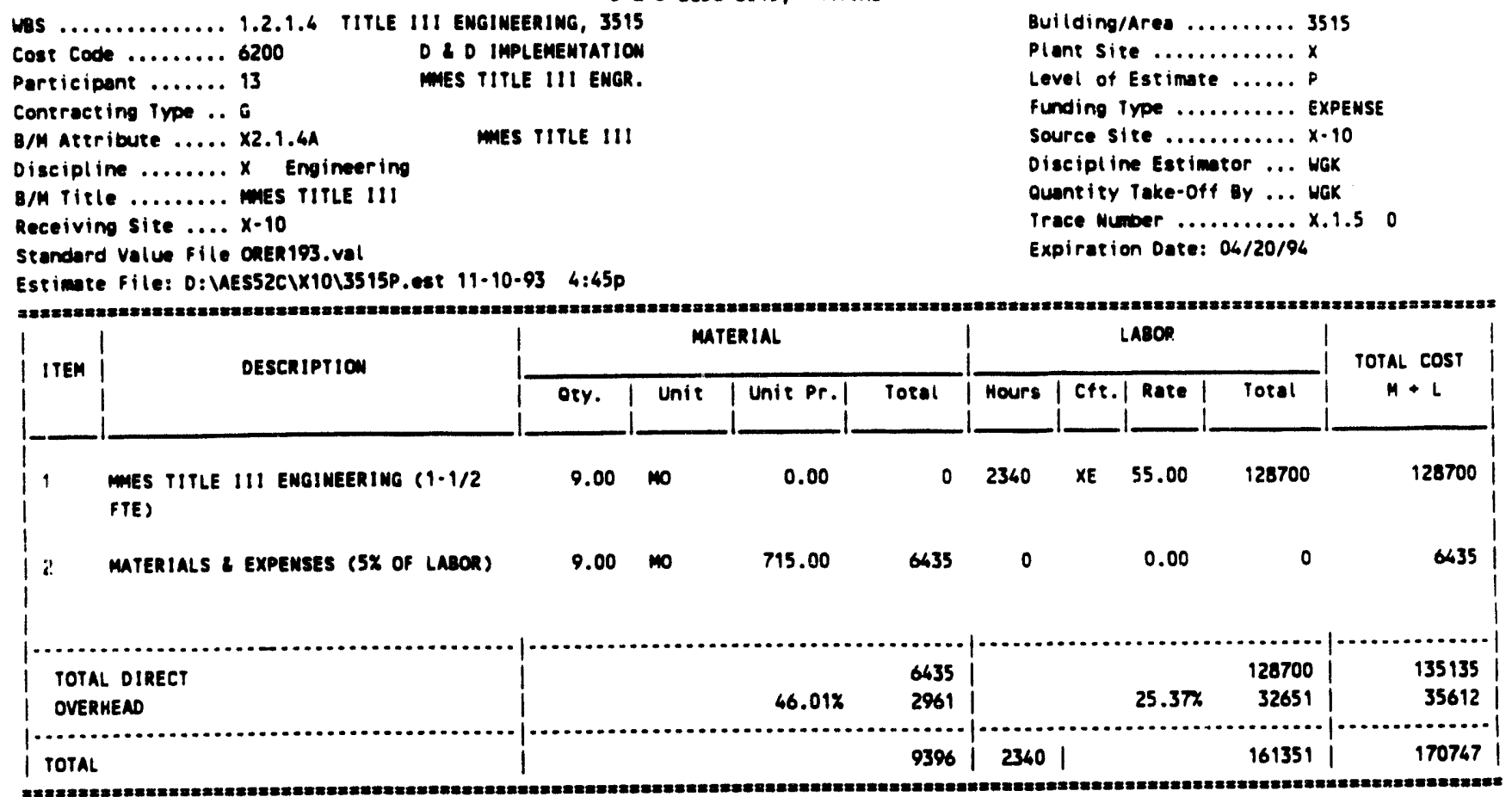


D D BLDG 3515, PARTIAL

wes.

Cost Cods ........ 5200

participant ....... 19

Contracting ivpe ... G

B/M Ateribute ...... X2.1,48

Discipline ........ $\times$ Engineering

B/m Tiele ......... A-e TItLe III

Receiving sire ..... X-10

stendard value fille Caren193.val

Estimate file: D:IAES52C1X10 $3515 p$.est $11 \cdot 10.93 \quad 4: 45 p$

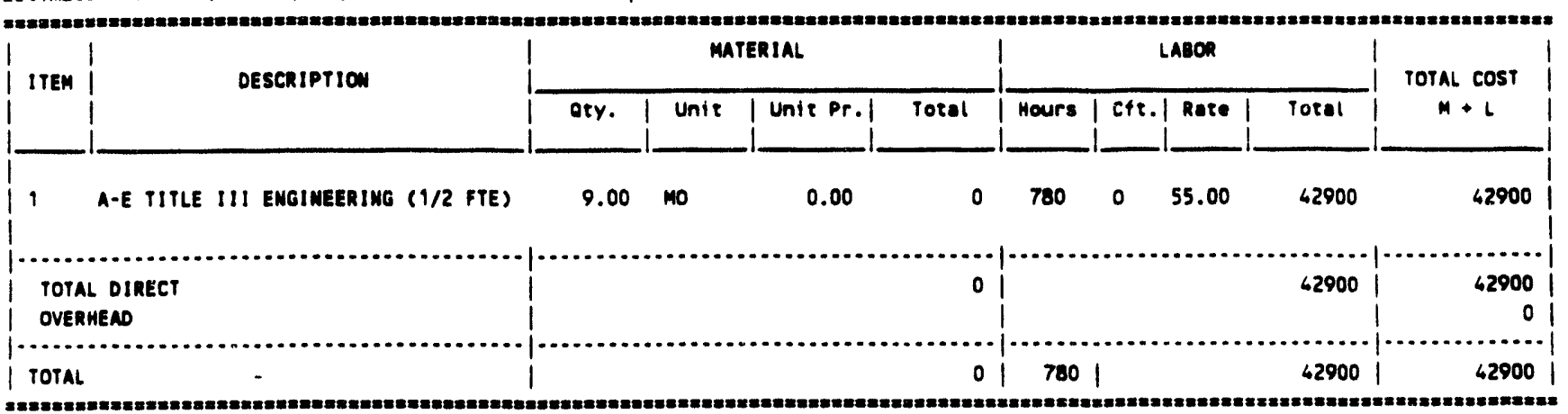

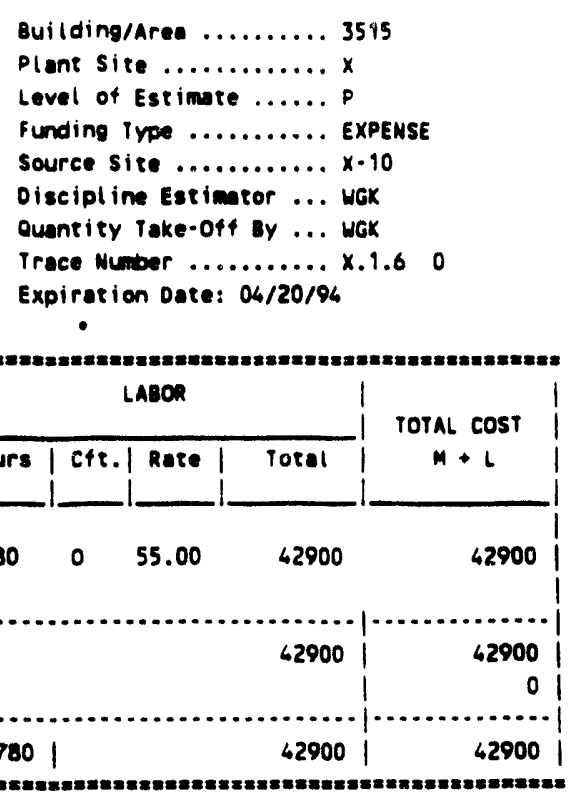

Building/area ......... 3575

D 2 DESICN

A-E TITLE III ENGR.

A-E TITLE III

Level of Estimate .......

Funding Iype .......... Expense

Discipline Estimer .... WGK

Quntity Take-0t4 By ... WGK

Trace Number ............ X.1.6

expiration Date: $04 / 20 / 96$

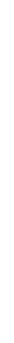

\section{D-15}


D 20 BLDG 3595, PARTIAL

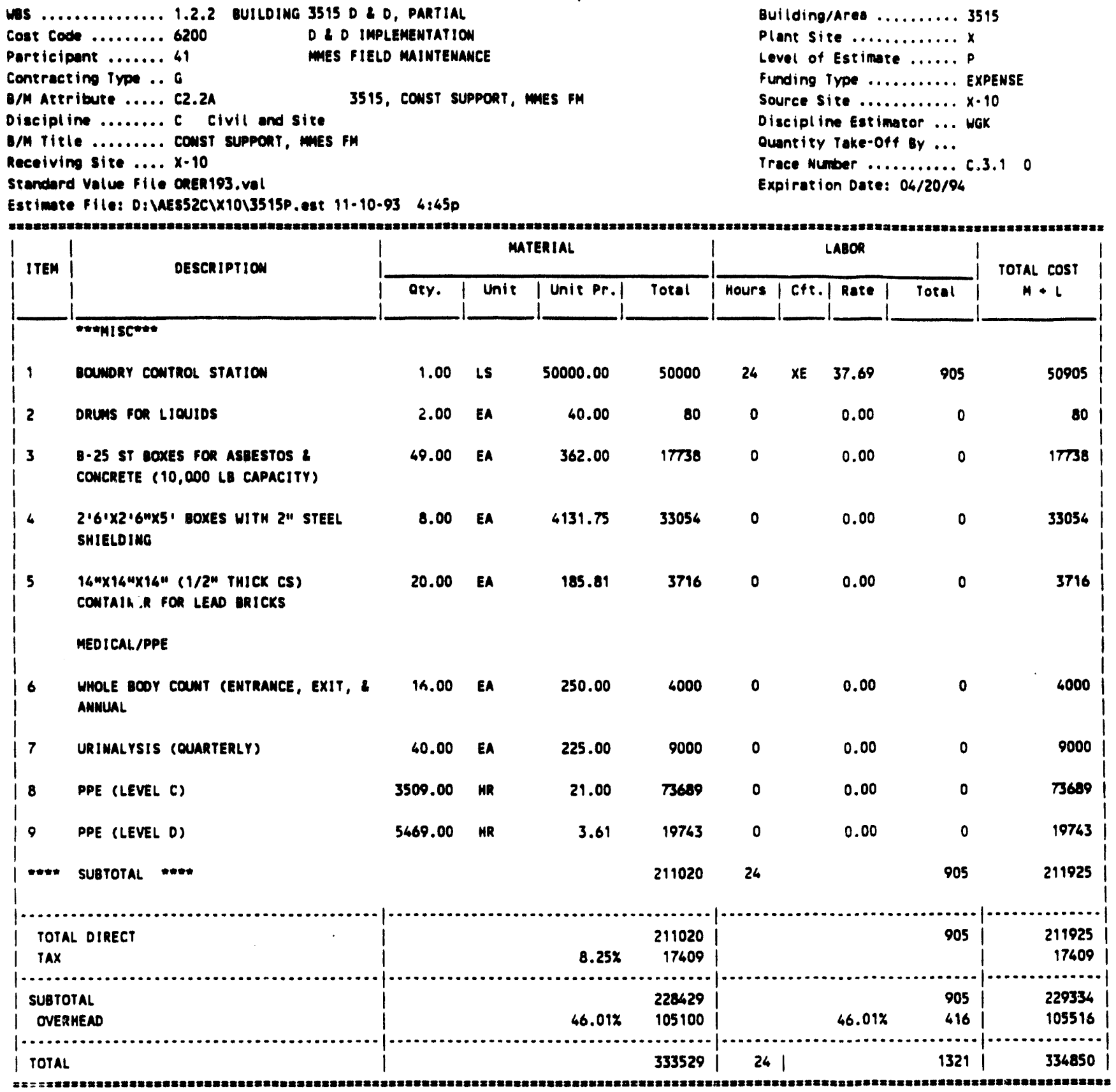


D L DLOG 3515, PARTIAL

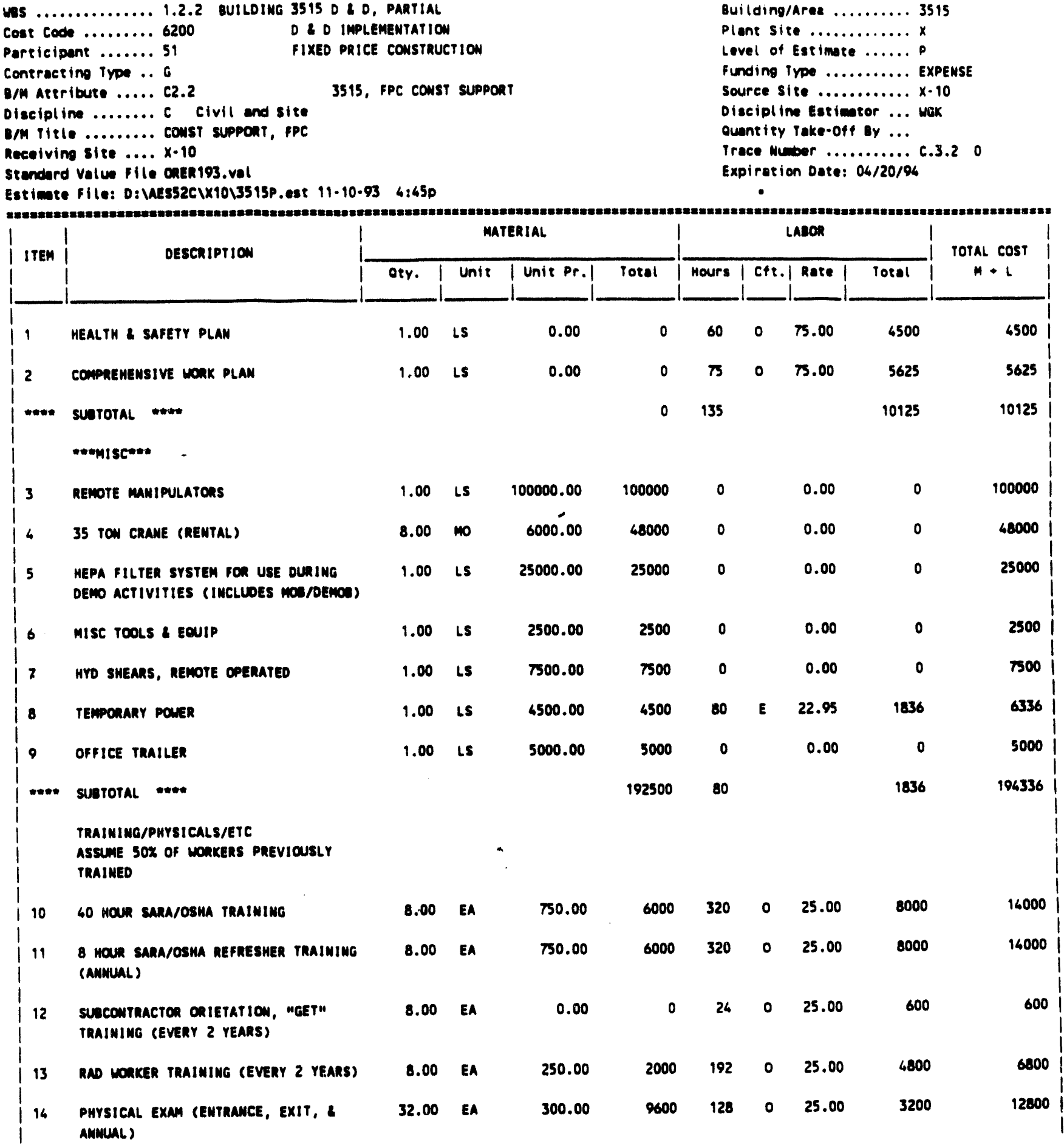


D 20 Llog 3515, paktial

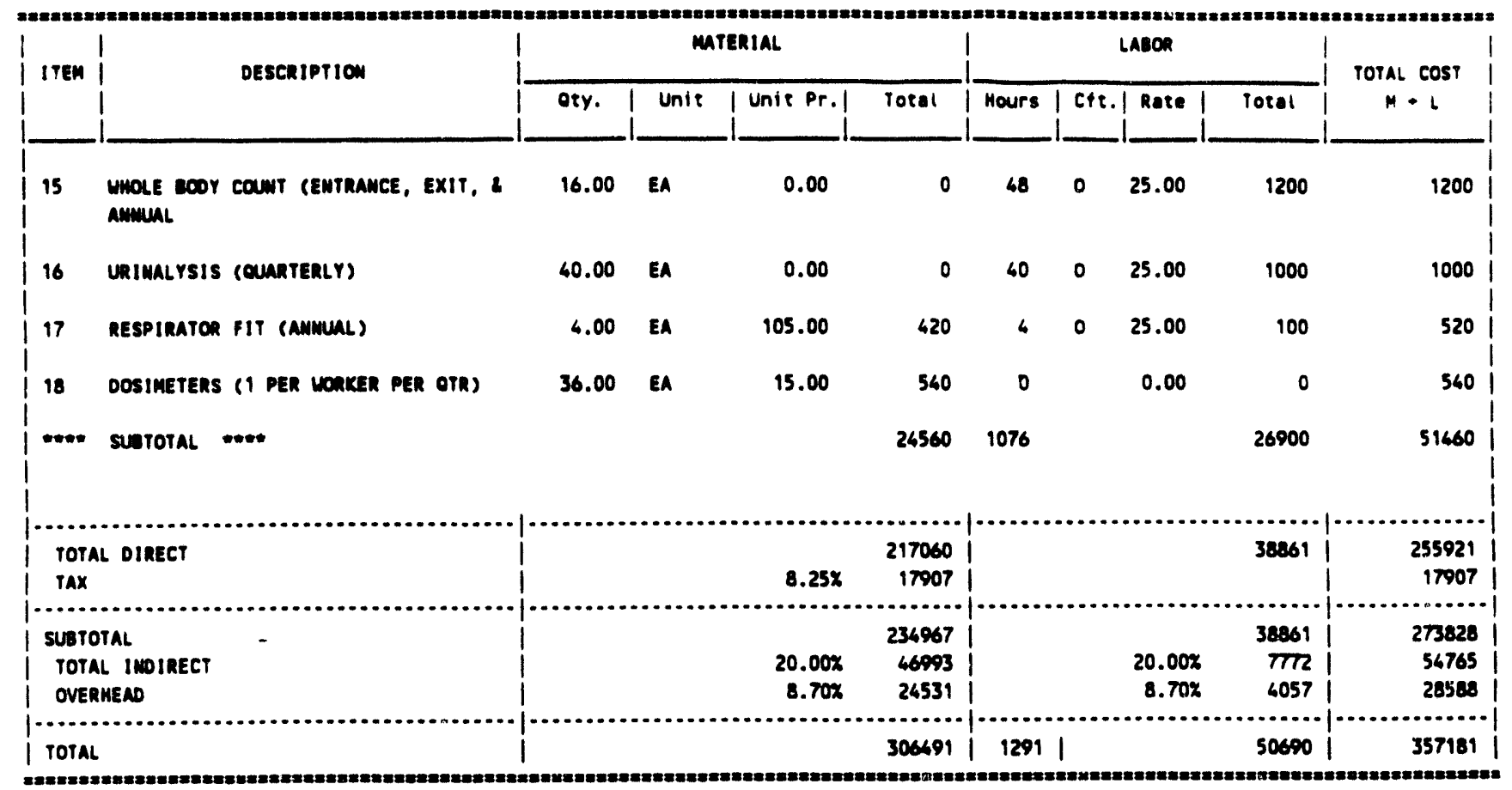


D D BLDG 3515, PARTIAL

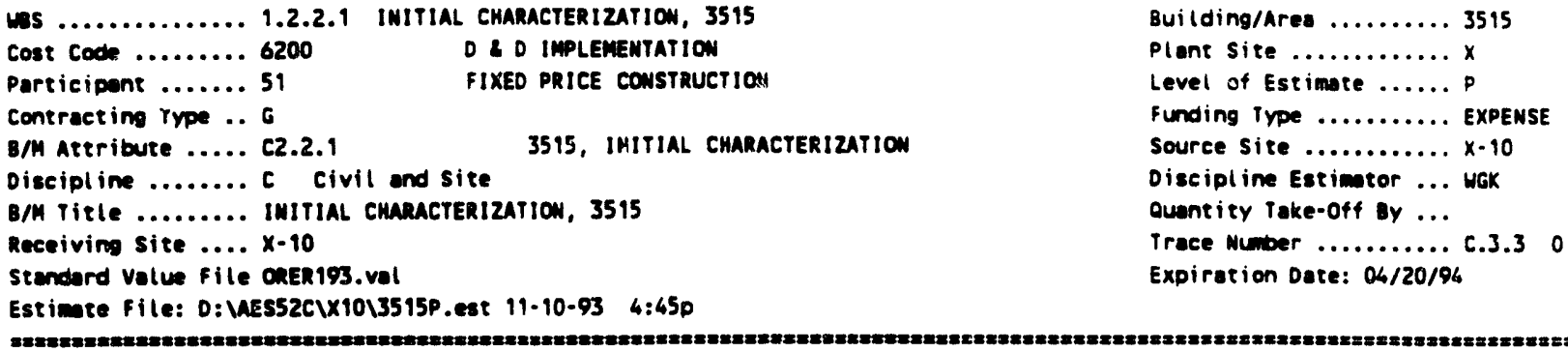

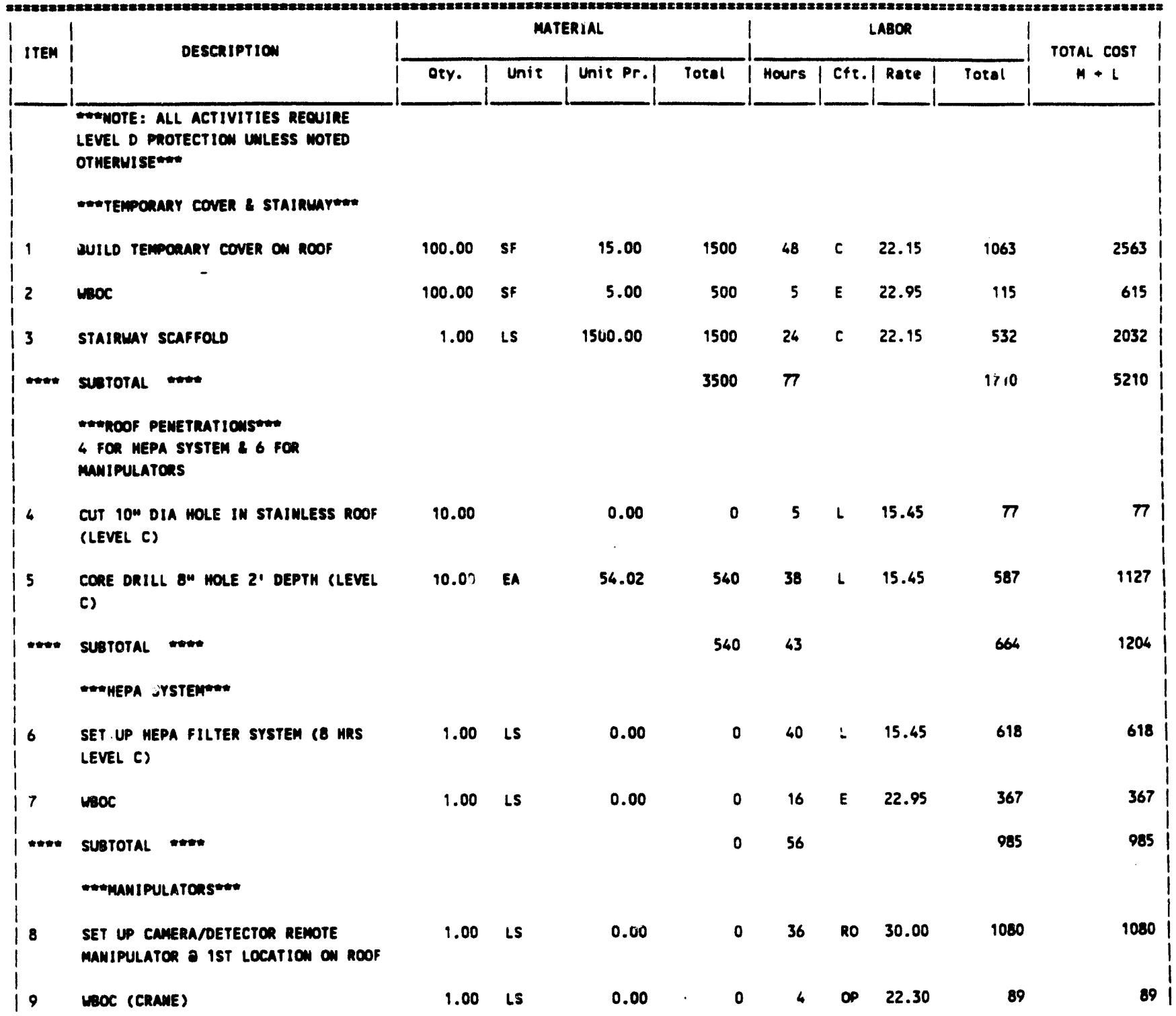


D 2 D BLD 3515, PARTIAL

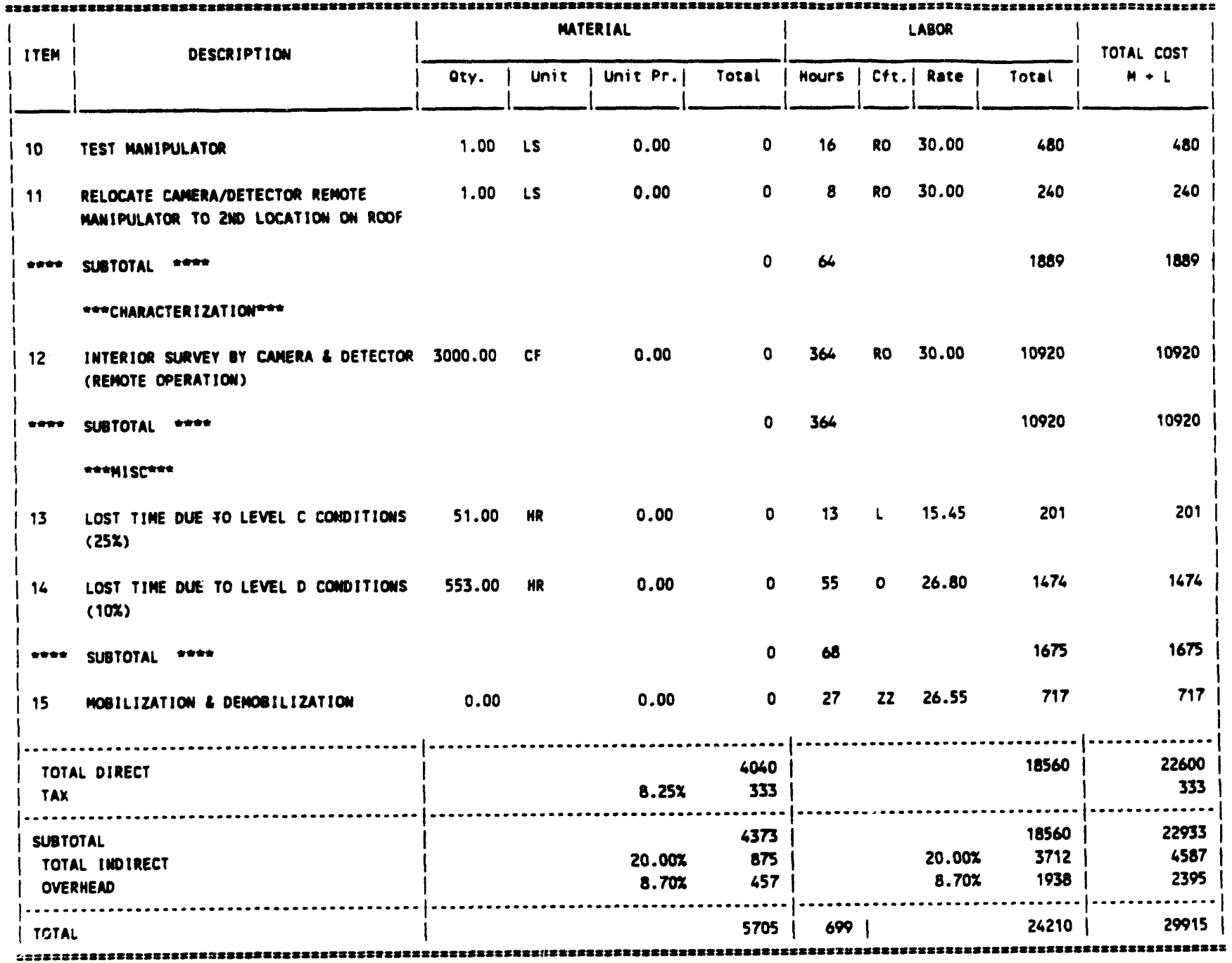




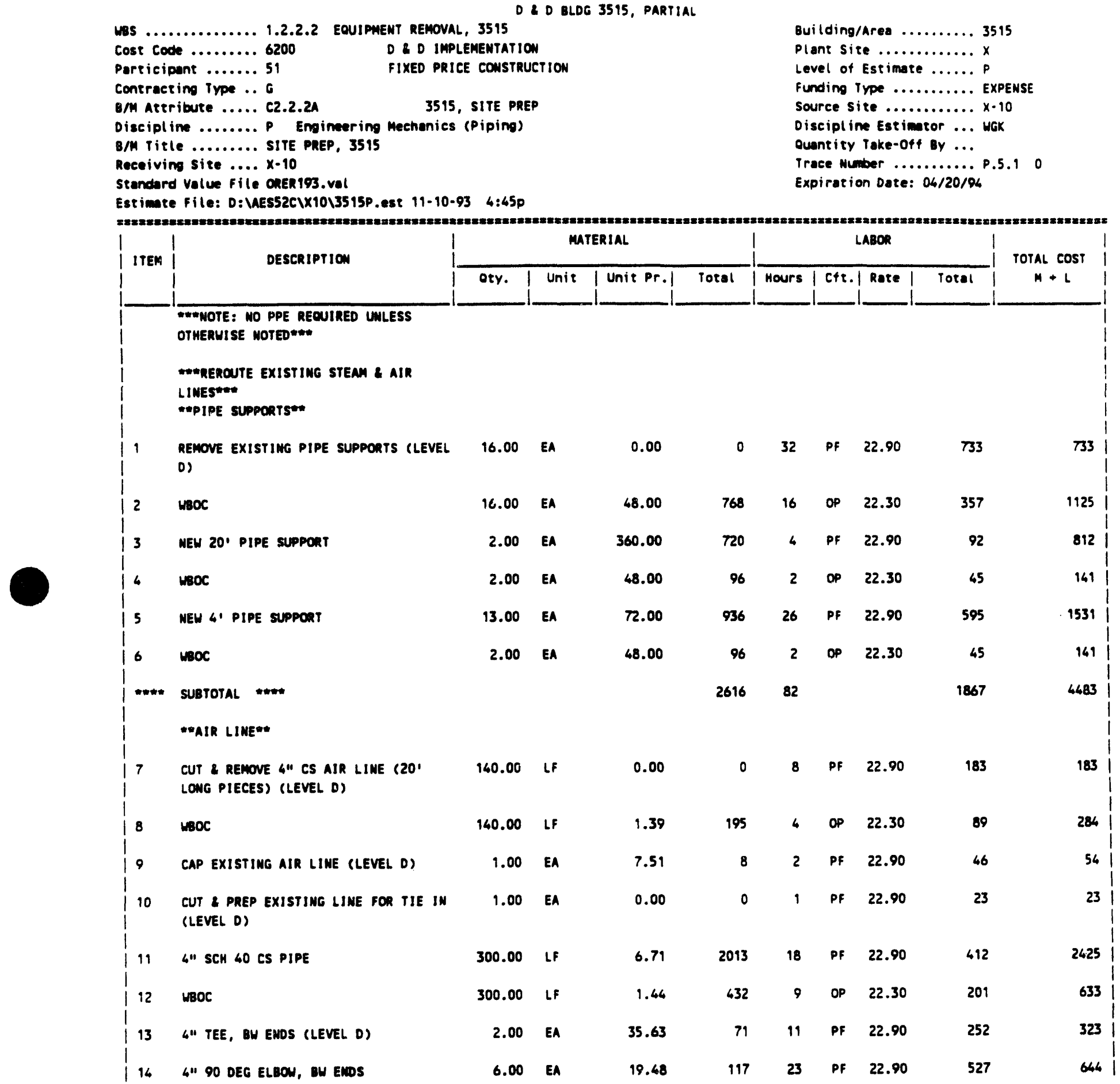


D \& BLDG 3515, PARTIAL

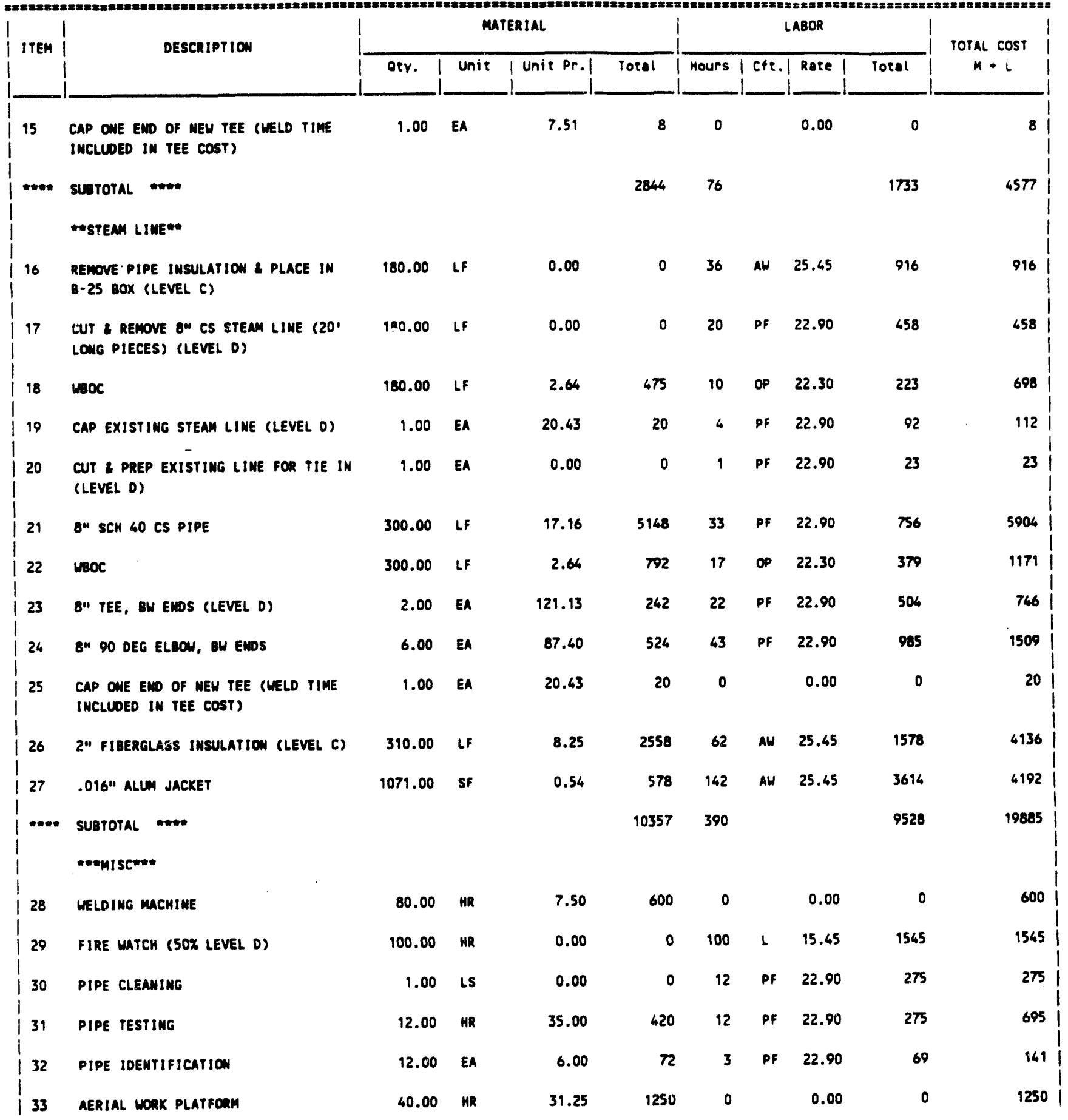


O 10 BLOG 3515, PARTIAL

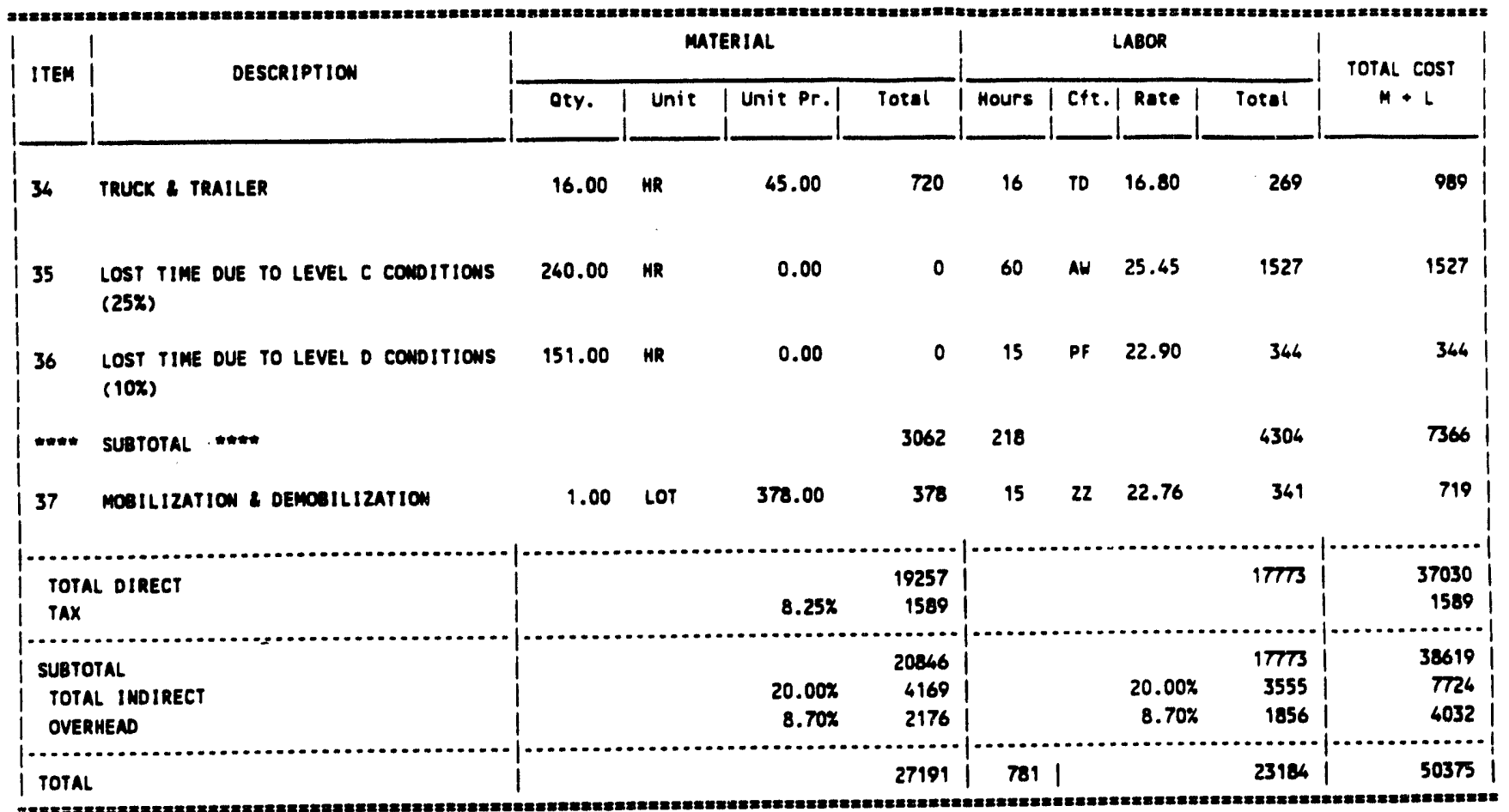


D \& O BLOG 3515, PARTIAL

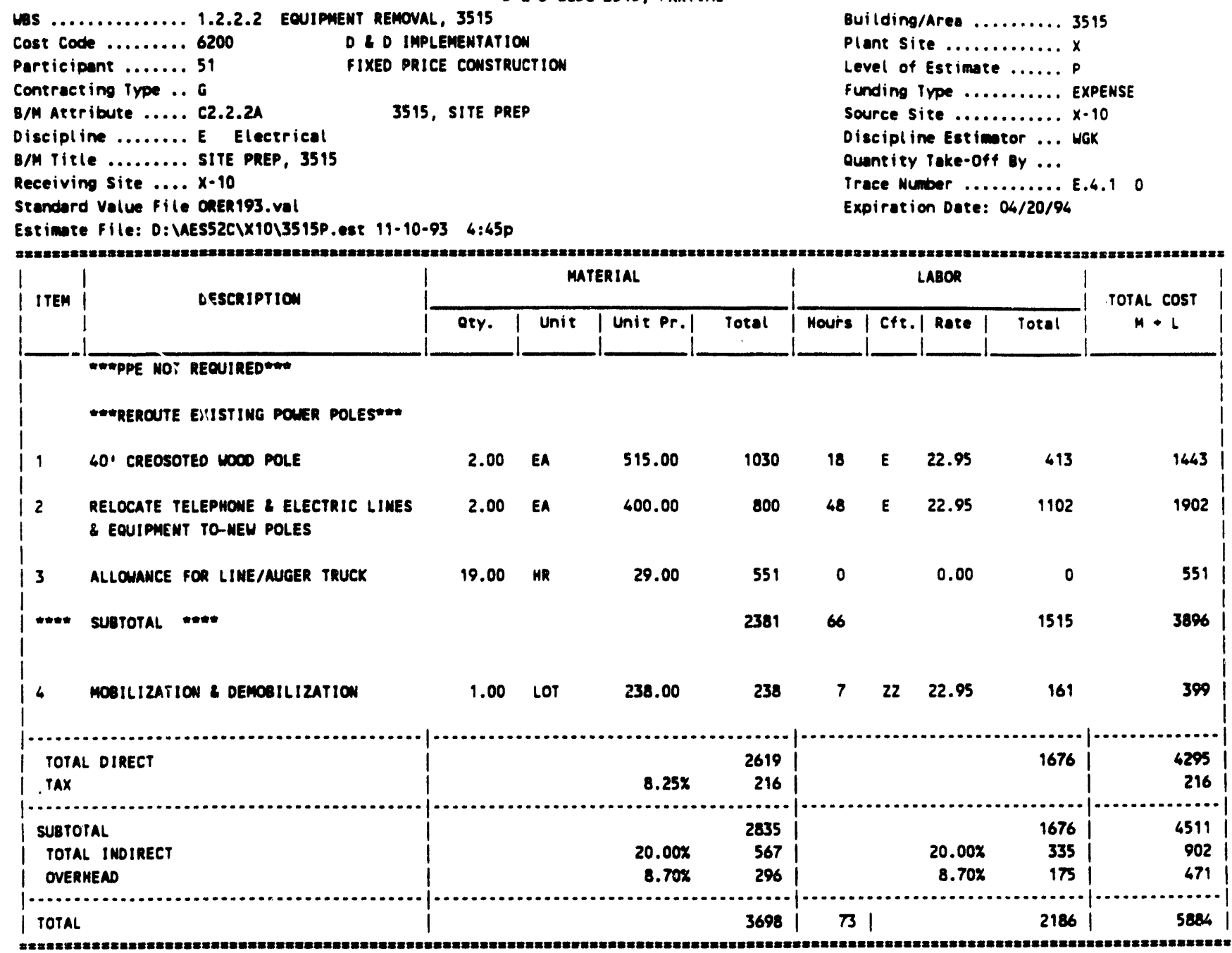


D 20 BLDG 3515, PARTIAL

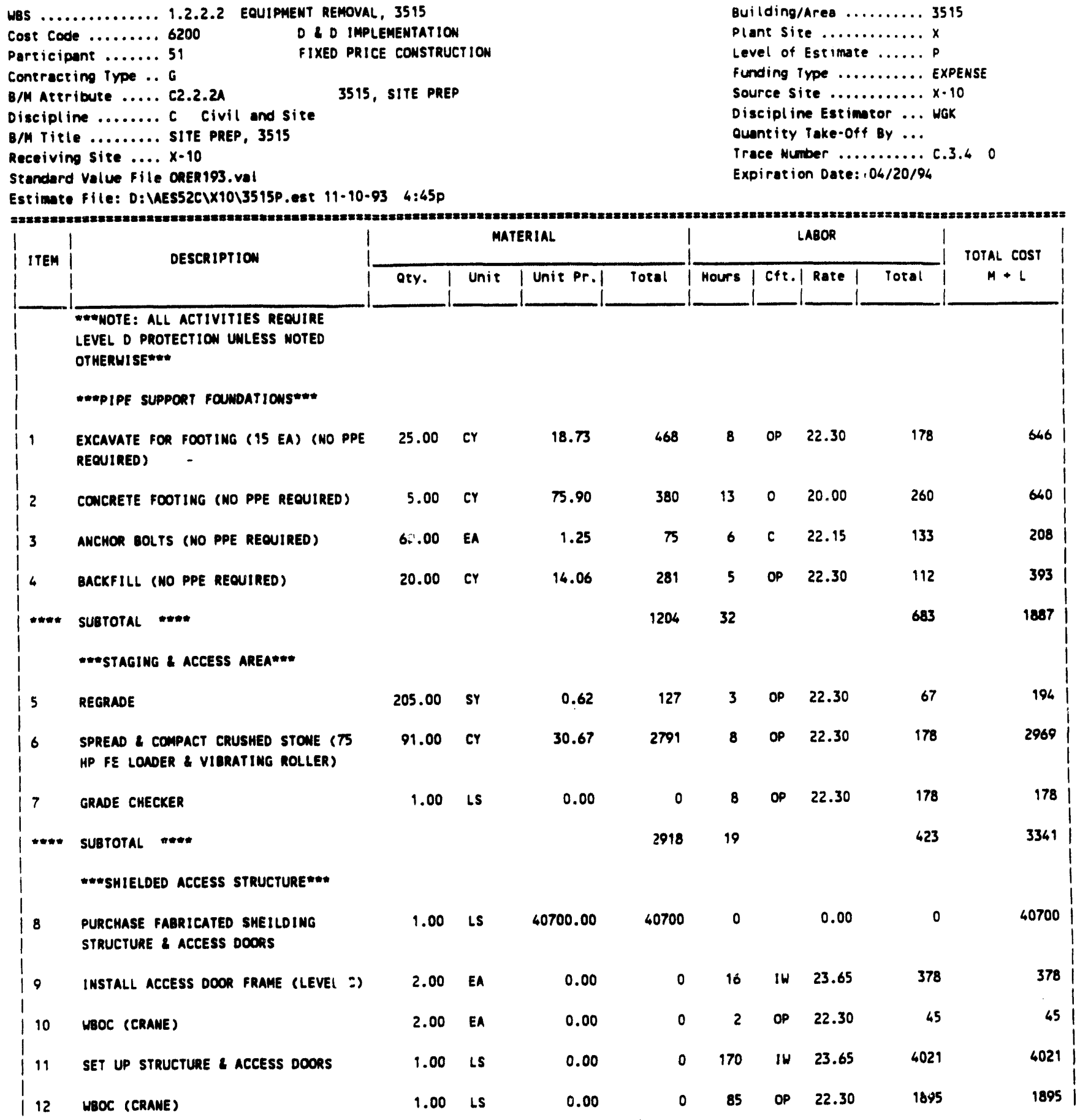


D D BLDG 3515, PARTIAL

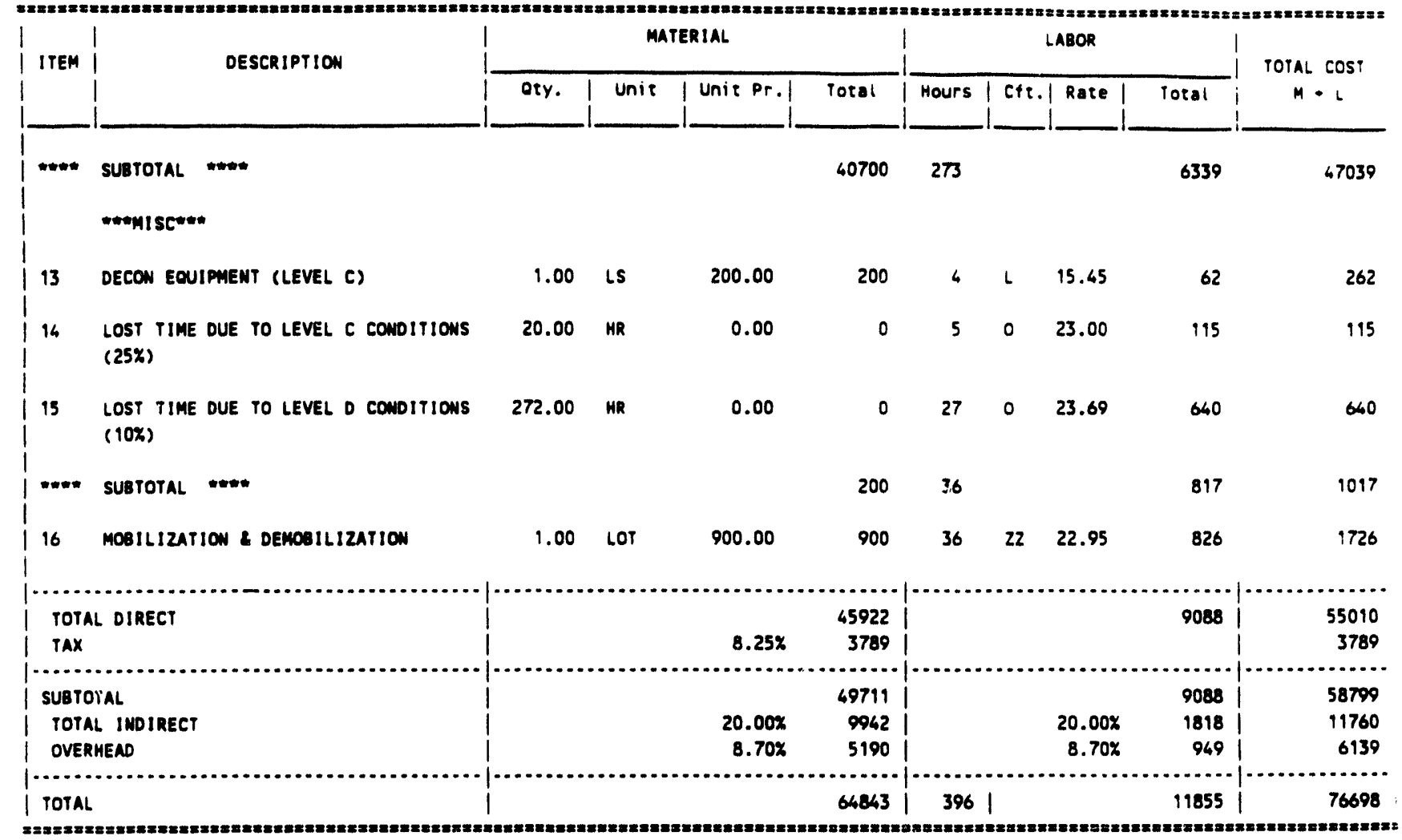


IO BLDG 3515, PARTIAL

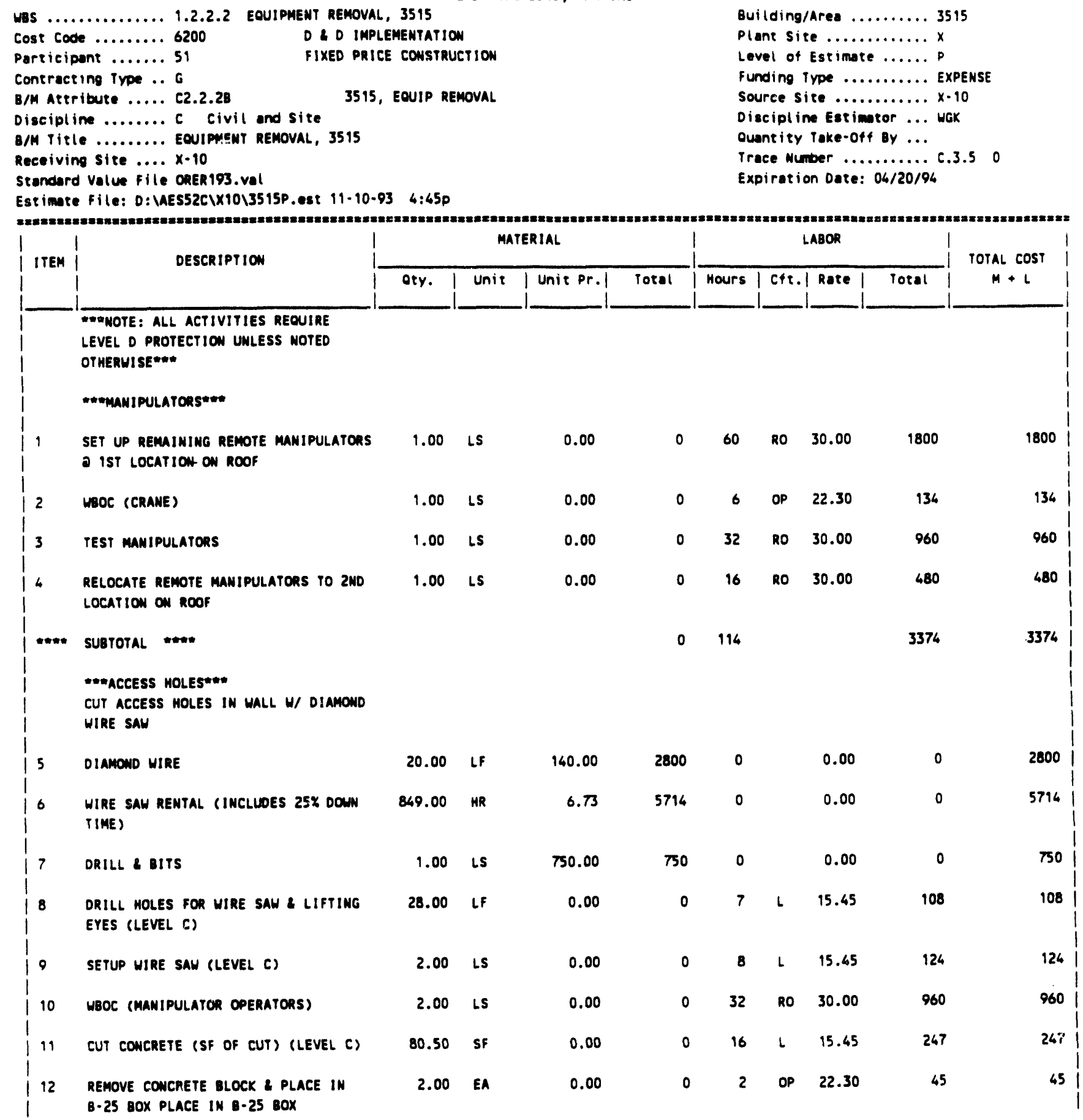


D \& D BLOG 3515, PARTIAL

\begin{tabular}{|c|c|c|c|c|c|c|c|c|c|c|}
\hline \multirow{2}{*}{ ITEM } & \multirow{2}{*}{ DESCRIPTION } & \multicolumn{4}{|c|}{ MATERIAL } & \multicolumn{4}{|c|}{ LABOR } & \multirow{2}{*}{ TOTAL COST } \\
\hline & & oty. & Unit & Unit Pr.l & Total & Hours & $c+t .1$ & | Rate & Total & \\
\hline 13 & WBOC (LEVEL C) & 2.00 & EA & 0.00 & 0 & 8 & $L$ & 15.45 & 124 & $124 \mid$ \\
\hline 14 & $\begin{array}{l}\text { PLACE ROLLER CONVEYOR IN OPENING } \\
\text { ANCHOR TO CONCRETE SLAB (LEVEL C) }\end{array}$ & 2.00 & EA & 1200.00 & 2400 & 8 & IW & 23.65 & 189 & 25891 \\
\hline 15 & weoc & 2.00 & EA & 0.00 & 0 & 4 & OP & 22.30 & 89 & 891 \\
\hline 16 & WBOC (RENOTE MANIPULATOR CREH) & 2.00 & EA & 0.00 & 0 & 16 & RO & 30.00 & 480 & 480 \\
\hline 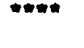 & SUBTOTAL "Ww & & & & 11664 & 101 & & & 2366 & 16030 \\
\hline & $\begin{array}{l}\text { "WEUILOIMG INTERMALS DEMOW" } \\
\text { MATERIALS WILL IE CUT UP \& PLACED IN } \\
\text { SHIELLED B-25 BOXES OY } 4 \text { MAN REMOTE } \\
\text { OPERATION CREN } \\
\text { "-LEAD BRICKS" } \\
\text { - }\end{array}$ & & & & & & & & & \\
\hline 17 & $\begin{array}{l}\text { PLACE CONTAINERS InSIDE BUILOING } \\
\text { (CRAME) }\end{array}$ & 8.00 & EA & 0.00 & 0 & 1 & $O P$ & 22.30 & 22 & 22 \\
\hline 18 & WBOC & 8.00 & EA & 0.00 & 0 & 1 & $L$ & 15.45 & 15 & $15 !$ \\
\hline 19 & $\begin{array}{l}\text { PLACE LEAD BRICKS IN CONTAINER (8 } \\
\text { CONTAINERS) }\end{array}$ & 8.00 & CF & 0.00 & 0 & 115 & RO & 30.00 & 3450 & 3450 \\
\hline 20 & $\begin{array}{l}\text { MIX EPOXY MIXTURE FOR CONTAINER VOID } \\
\text { SPACES }\end{array}$ & 8.00 & EA & 84.00 & 672 & 1 & $L$ & 15.45 & 15 & 687 \\
\hline 21 & $\begin{array}{l}\text { PLACE EPOXY MIXTURE INSIDE BUILDING } \\
\text { (CRANE) }\end{array}$ & 8.00 & EA & 0.00 & 0 & 1 & $O P$ & 22.30 & 22 & 22 \\
\hline 22 & WBOC & 8.00 & EA & 0.00 & 0 & 1 & $\downarrow$ & 15.45 & 15 & 15 \\
\hline 23 & $\begin{array}{l}\text { FILL VOIO SPACES IN CONTAIMERS WITH } \\
\text { EPOXY }(.42 \text { CF PER CONTAIMER) }\end{array}$ & 8.00 & EA & 0.00 & 0 & 5 & RO & 30.00 & 150 & 150 \\
\hline 24 & $\begin{array}{l}\text { REMOVE CONTAINER FROM BUILDING } \\
\text { (CRANE) }\end{array}$ & 8.00 & EA & 0.00 & 0 & 1 & $O P$ & 22.30 & 22 & 22 \\
\hline 25 & WBOC (LEVEL C) & 8.00 & EA & 0.00 & 0 & 1 & $L$ & 15.45 & 15 & 15 \\
\hline 26 & PLACE COVER ON CONTAINER (LEVEL C) & 8.00 & EA & 0.00 & 0 & 16 & $\mathbf{L}$ & 15.45 & 247 & 247 \\
\hline 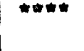 & SUBTOTAL & & & & 672 & 143 & & & 3973 & 4645 \\
\hline & "LIOUIDS" & & & & & & & & & \\
\hline 27 & SET UP \& ATTACH PLAP & 5.00 & LS & 0.00 & 0 & 60 & RO & 30.00 & 1800 & 1800 \\
\hline 28 & REMOVE \& DRUN LIOUIOS & 100.00 & GAL & 0.00 & 0 & 8 & RO & 30.00 & 240 & 240 \\
\hline
\end{tabular}


D \& DLDG 3515, PARTIAL

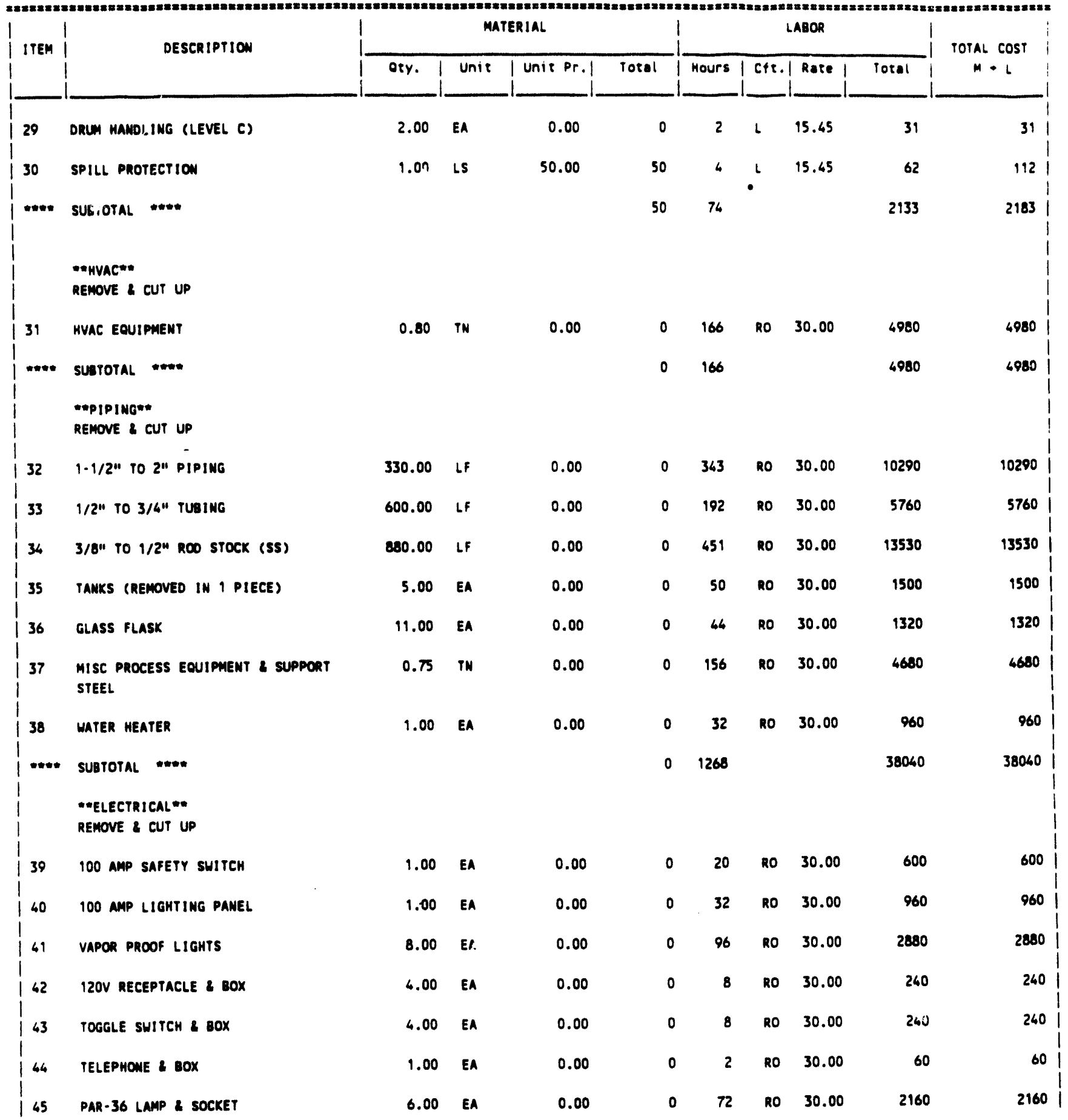


D 2 BLOG 3515, PARTIAL

\begin{tabular}{|c|c|c|c|c|c|c|c|c|c|c|}
\hline \multirow{2}{*}{ ITEM } & \multirow{2}{*}{ DESCRIPTION } & \multicolumn{4}{|c|}{ MATERIAL } & \multicolumn{4}{|c|}{ LABOR } & \multirow{2}{*}{$\begin{array}{c}\text { TOTAL } \cos T \\
M+L\end{array}$} \\
\hline & & aty. & Unit & Unit Pr.l & Total & Hours & Cft. & | Rate | & lotal & \\
\hline 46 & I" $3 / 4$ " conoult & 1.00 & LOT & 0.00 & 0 & 106 & RO & 30.00 & 3120 & 3120 \\
\hline 47 & CABLE & 1.00 & tor & 0.00 & 0 & 104 & RO & 30.00 & 3120 & 3120 \\
\hline$\omega t$ & SUBTOTAL mitm & & & & 0 & 446 & & & 13380 & 13380 \\
\hline 48 & $\begin{array}{l}\text { PLACE SHIELDED BOX IN BUILDING } \\
\text { (CRANE) }\end{array}$ & 8.00 & EA & 0.00 & 0 & 8 & $O P$ & 22.30 & 178 & 178 \\
\hline 49 & WBOC & 8.00 & EA & 0.00 & 0 & 16 & $\mathbf{L}$ & 15.45 & 247 & 267 \\
\hline 50 & WBOC (REMOTE MANIPULATOR CREH) & 8.00 & EA & 0.00 & 0 & 32 & RO & 30.00 & 960 & 9601 \\
\hline 51 & $\begin{array}{c}\text { PLACE MATERIAL IN SHIELDED BOX } \\
-\end{array}$ & 8.00 & EA & 0.00 & 0 & 256 & RO & 30.00 & 7680 & 76801 \\
\hline 52 & REMOVE SHIELDED BOX FROM BUILOING & 8.00 & EA & 0.00 & 0 & 8 & OP & 22.30 & 178 & i78 \\
\hline 53 & WBOC (LEVEL C) & 8.00 & EA & 0.00 & 0 & 16 & \llcorner & 15.45 & 247 & $267 !$ \\
\hline 54 & MEOC (REMOTE MANIPULATOR CREW) & 8.00 & EA & 0.00 & 0 & 32 & RO & 30.00 & 960 & 9601 \\
\hline 55 & PLACE COVER ON SHIELDED BOX (CRANE) & 8.00 & EA & 0.00 & 0 & 8 & OP & 22.30 & 178 & 178 \\
\hline 56 & WOC (LEVEL C) & 8.00 & EA & 0.00 & 0 & 32 & 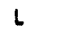 & 15.45 & 494 & 694 \\
\hline 1..$+\infty$ & SUBTOTAL H"W" & & & & 0 & 408 & & & 11122 & 11122 \\
\hline 57 & $\begin{array}{l}\text { LOST TIME DUE TO LEVEL C CONDITIONS } \\
(25 \%)\end{array}$ & 38.00 & MR & 0.00 & 0 & 10 & 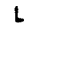 & 15.45 & 155 & 155 \\
\hline 58 & $\begin{array}{l}\text { LOST TIME DUE TO LEVEL D CONDITIONS } \\
(10 \%)\end{array}$ & 2753.00 & HR & 0.00 & 0 & 275 & 0 & 29.60 & 8140 & 8140 \\
\hline 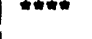 & SUBTOTAL WH & & & & 0 & 285 & & & 8295 & 8295 \\
\hline 59 & MOBILIZATION \& DEMOBILIZATION & 0.00 & & 0.00 & 0 & 60 & 22 & 29.17 & 1750 & 1750 \\
\hline TOTAL & L DIRECT & & & & 12386 & & & & 89413 & 101799 \\
\hline $\operatorname{TAX}$ & & & & $8.25 \%$ & 1022 & & & & & 1022 \\
\hline I suBto & TAL & & & & 13408 & & & & 896131 & 102821 \\
\hline TOTA1 & L INDIRECT & & & $20.00 \%$ & 2682 I & & & $20.00 \%$ & 17803 & 20565 \\
\hline OVER! & MEAD & & & $8.70 x$ & 14001 & & & $8.70 x$ & 9335 & 10735 \\
\hline | TOTAL & & & & & 17490 & 30651 & & & 116631 & 134121 \\
\hline
\end{tabular}


D 20 BLOG 3515, PARTIAL

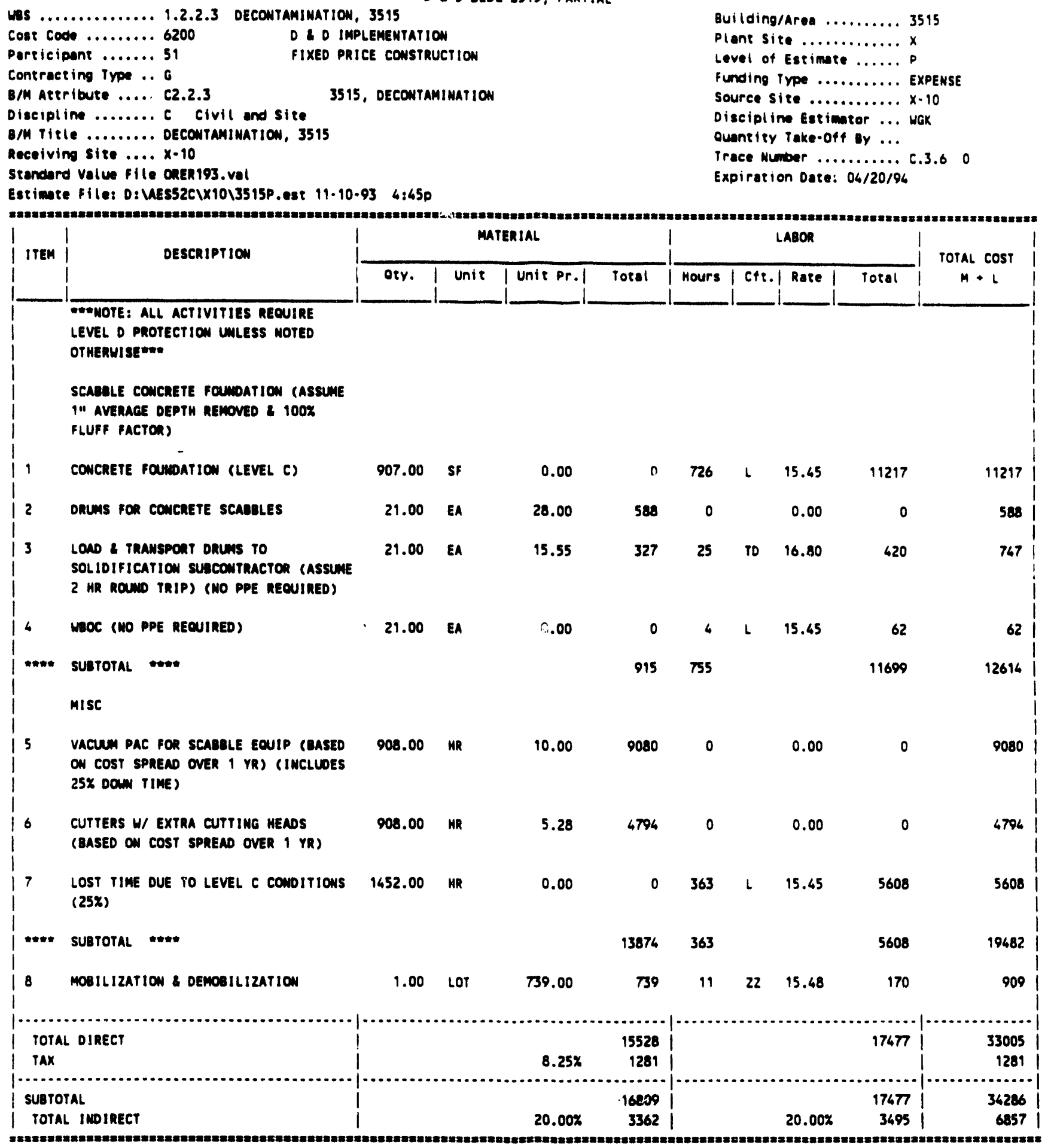


D o bloo 3515, partial

ITEM | OESCRIPTIOW



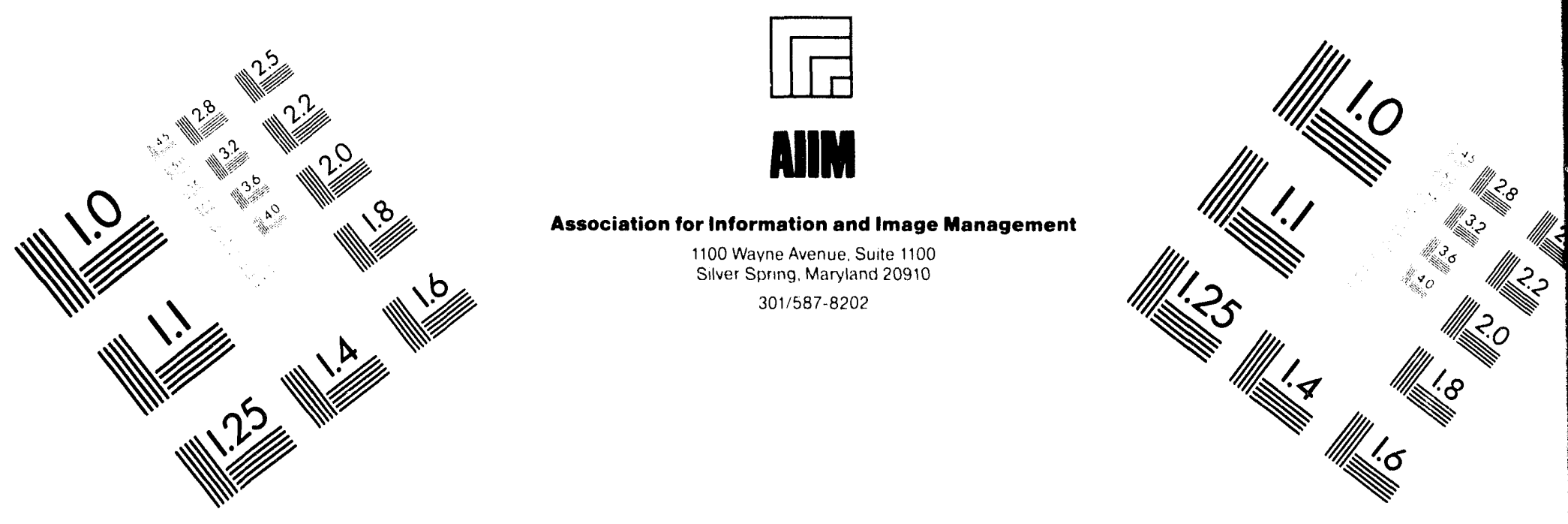

\section{Centimeter}

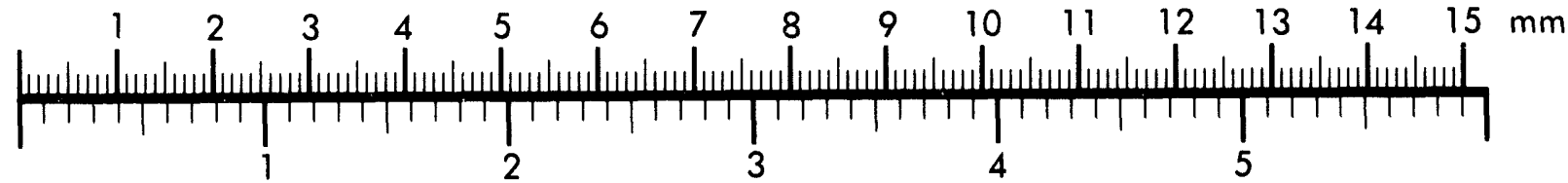

Inches
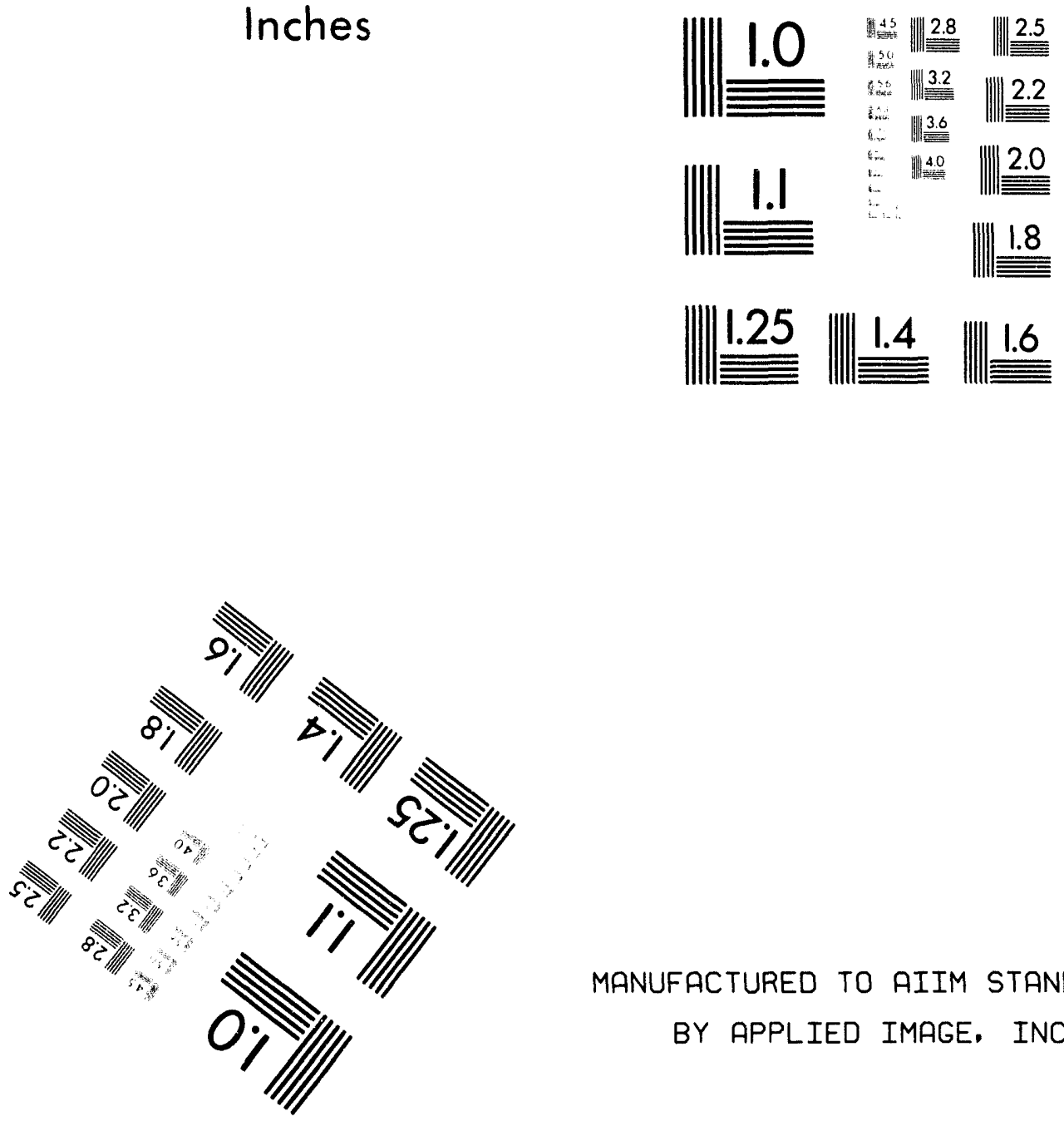

MANUFACTURED TO AIIM STANDARDS

BY APPLIED IMAGE, INC.

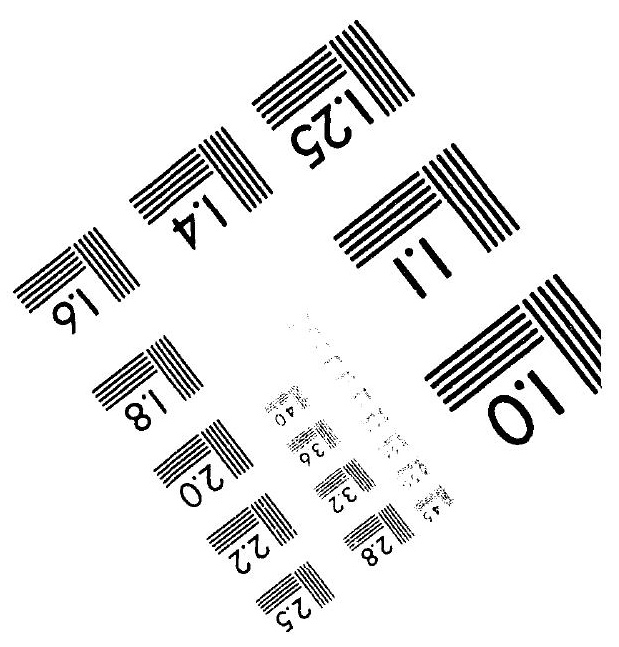



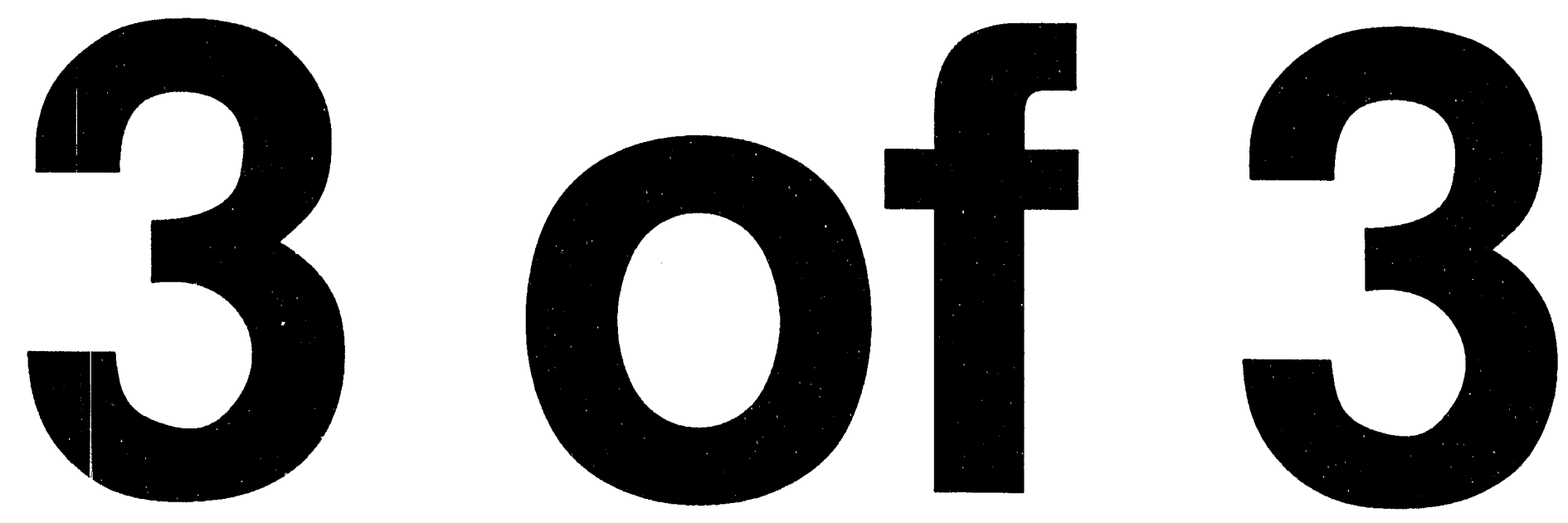
D O 8LDG 3515, PARTIAL

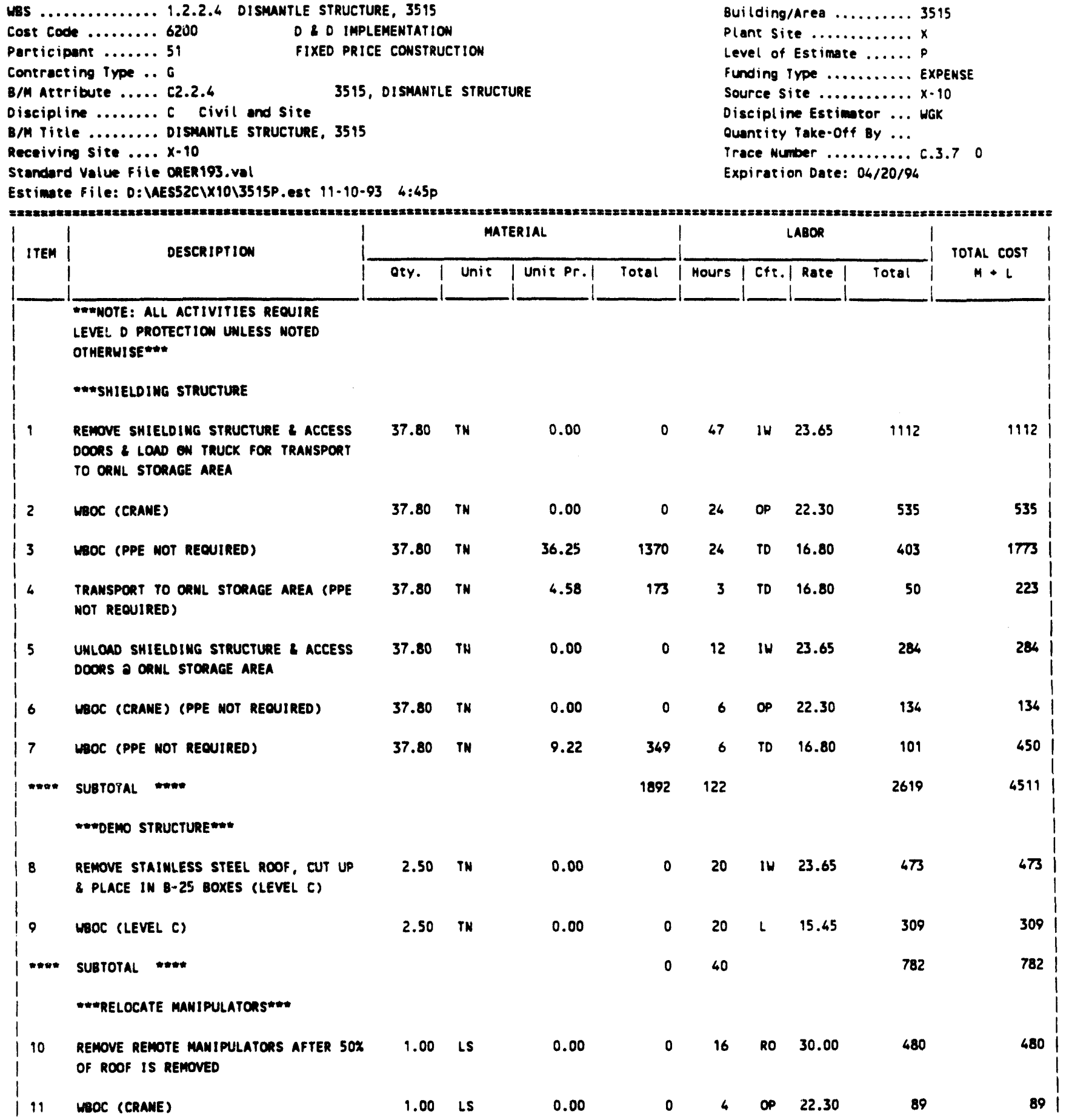


D D BLDG 3515, PARTIAL

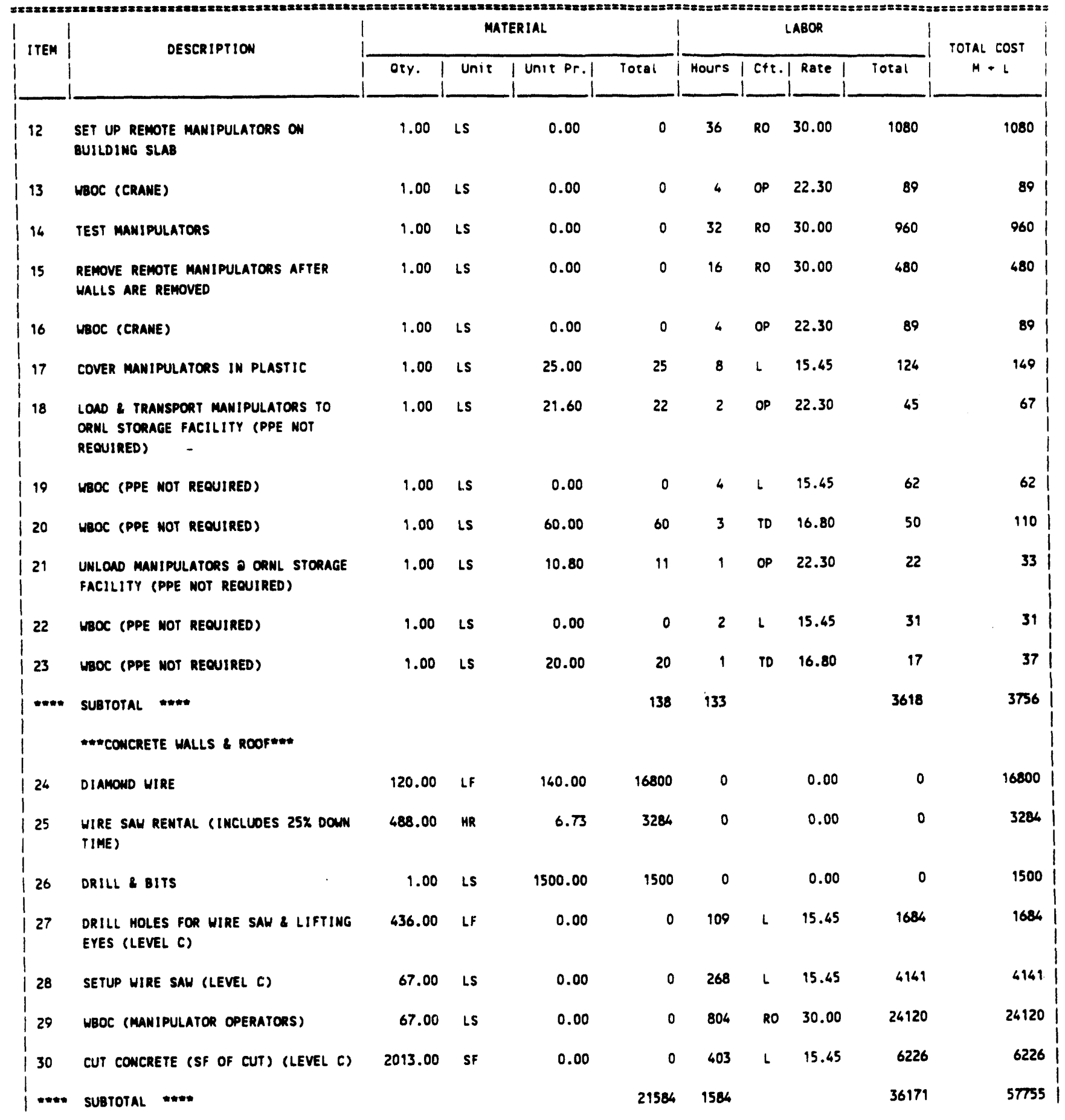


D I BLDG 3515, PARTIAL

\begin{tabular}{|c|c|c|c|c|c|c|c|c|c|c|}
\hline \multirow{2}{*}{ ITEM } & \multirow{2}{*}{ DESCRIPTION } & \multicolumn{4}{|c|}{ MATERIAL } & \multicolumn{4}{|c|}{ LABOR } & \multirow{2}{*}{$\begin{array}{c}\text { TOTAL COST } \\
M+L\end{array}$} \\
\hline & & aty. & Unit & Unit Pr.l & Total & Hours & $c f t$ & I Rate & Total & \\
\hline & "HPACKaGe CONCRETE BLOCKS"** & & & & & & & & & \\
\hline 31 & LIFTING EYES & 1.00 & LS & 750.00 & 750 & 0 & & 0.00 & 0 & 750 \\
\hline 32 & $\begin{array}{l}\text { INSTALL LIFTING EYE FOR CONCRETE } \\
\text { PIECES (LEVEL C) }\end{array}$ & 172.00 & EA & 0.00 & 0 & 26 & $\downarrow$ & 15.45 & 402 & 402 \\
\hline 33 & $\begin{array}{l}\text { PLACE. CONCRETE PIECES INTO B- } 25 \\
\text { BOXES FOR DISPOSAL ( } 48 \text { BOXES } \\
\text { REOUIREO) }\end{array}$ & 86.00 & PC & 12.00 & 1032 & 22 & $O P$ & 22.30 & 491 & 1523 \\
\hline 34 & WBOC (LEVEL C) & 86.00 & PC & 0.00 & 0 & 43 & $\mathbf{L}$ & 15.45 & 666 & 666 \\
\hline 35 & PLACE COVER ON BOX & 48.00 & EA & 0.00 & 0 & 24 & $O P$ & 22.30 & 535 & 535 \\
\hline 36 & WBOC (LEVEL C) & 48.00 & EA & 0.00 & 0 & 146 & $L$ & 15.45 & 2225 & 2225 \\
\hline 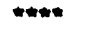 & SUBTOTAL & & & & 1782 & 259 & & & 4317 & 6099 \\
\hline 37 & $\begin{array}{l}\text { PLACE LEAD BRICKS IN CONTAIMER } \\
\text { (MAMIPULATOR OPERATORS) }\end{array}$ & 12.00 & $C F$ & 0.00 & 0 & 173 & RO & 30.00 & 5190 & 5190 \\
\hline 38 & $\begin{array}{l}\text { MIX EPOXY MIXTURE FOR CONTAINER VOID } \\
\text { SPACES (. } 42 \text { CF PER CONTAIMER) }\end{array}$ & 12.00 & EA & 84.00 & 1008 & 2 & $L$ & 15.45 & 31 & 1039 \\
\hline 39 & $\begin{array}{l}\text { FILL VOIO SPACES IN CONTAINERS WITH } \\
\text { EPOXY (MANIPULATOR OPERATORS) }\end{array}$ & 12.00 & EA & 0.00 & 0 & 8 & RO & 30.00 & 240 & 240 \\
\hline 40 & PLACE COVER ON CONTAINER (LEVEL C) & 12.00 & EA & 0.00 & 0 & 24 & $L$ & 15.45 & 371 & 371 \\
\hline \%** & SUBTOTAL WHAt & & & & 1008 & 207 & & & 5832 & 6840 \\
\hline 61 & $\begin{array}{l}\text { LOST TIME DUE TO LEVEL C CONDITIONS } \\
(25 \%)\end{array}$ & 1057.00 & MR & 0.00 & 0 & 264 & 0 & 22.76 & 6003 & 6003 \\
\hline 42 & $\begin{array}{l}\text { LOST TIME DUE TO LEVEL D CONDITIONS } \\
(10 \%)\end{array}$ & 1233.00 & HR & 0.00 & 0 & 123 & 0 & 29.71 & 3654 & 3654 \\
\hline 43 & MOBILIZATION \& DEMOBILIZATION & 1.00 & LOT & 528.00 & 528 & 82 & 22 & 23.06 & 1891 & 2419 \\
\hline TOTAL & $\perp$ DIRECT & & & & 26932 & & & & 64887 & 91819 \\
\hline $\operatorname{tax}$ & & & & $8.25 \%$ & 2222 & & & & & 2222 \\
\hline SUBTO & & & & & 29154 & & & & $\begin{array}{l}64887 \\
12077\end{array}$ & $\begin{array}{l}94041 \\
18908\end{array}$ \\
\hline TOTA: & L IMDIRECT & & & $20.00 \%$ & 5831 & 1 & & $20.00 \%$ & 12977 & 18000 \\
\hline
\end{tabular}


D \& O BLOG 3515, PARTIAL

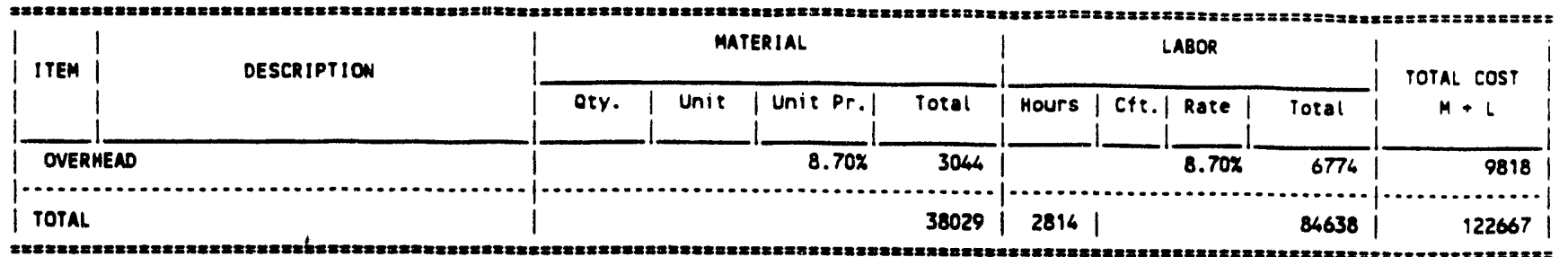


D \& BLDG 3515, PARTIAL

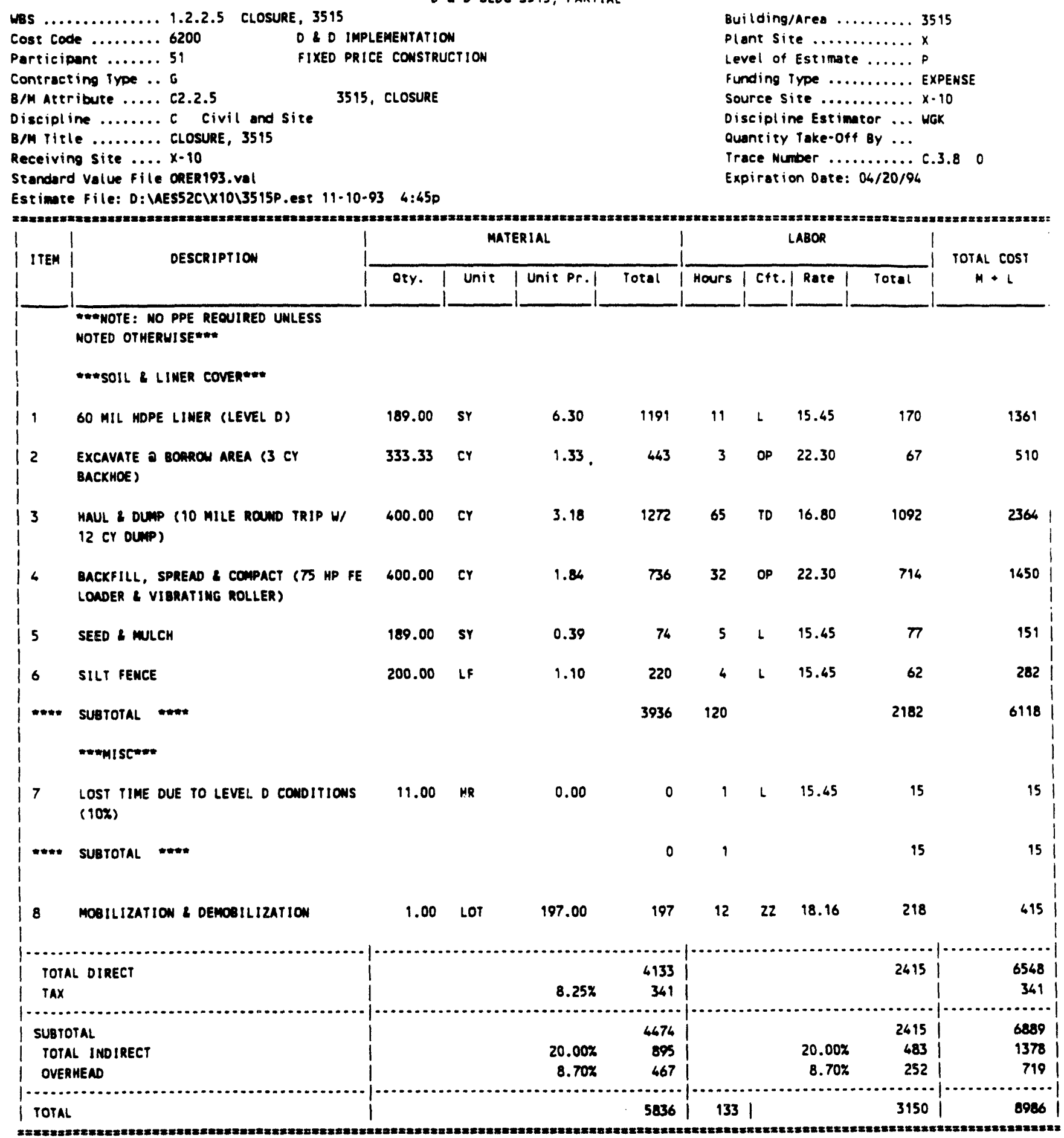


D D BLDG 3515, PARTIAL

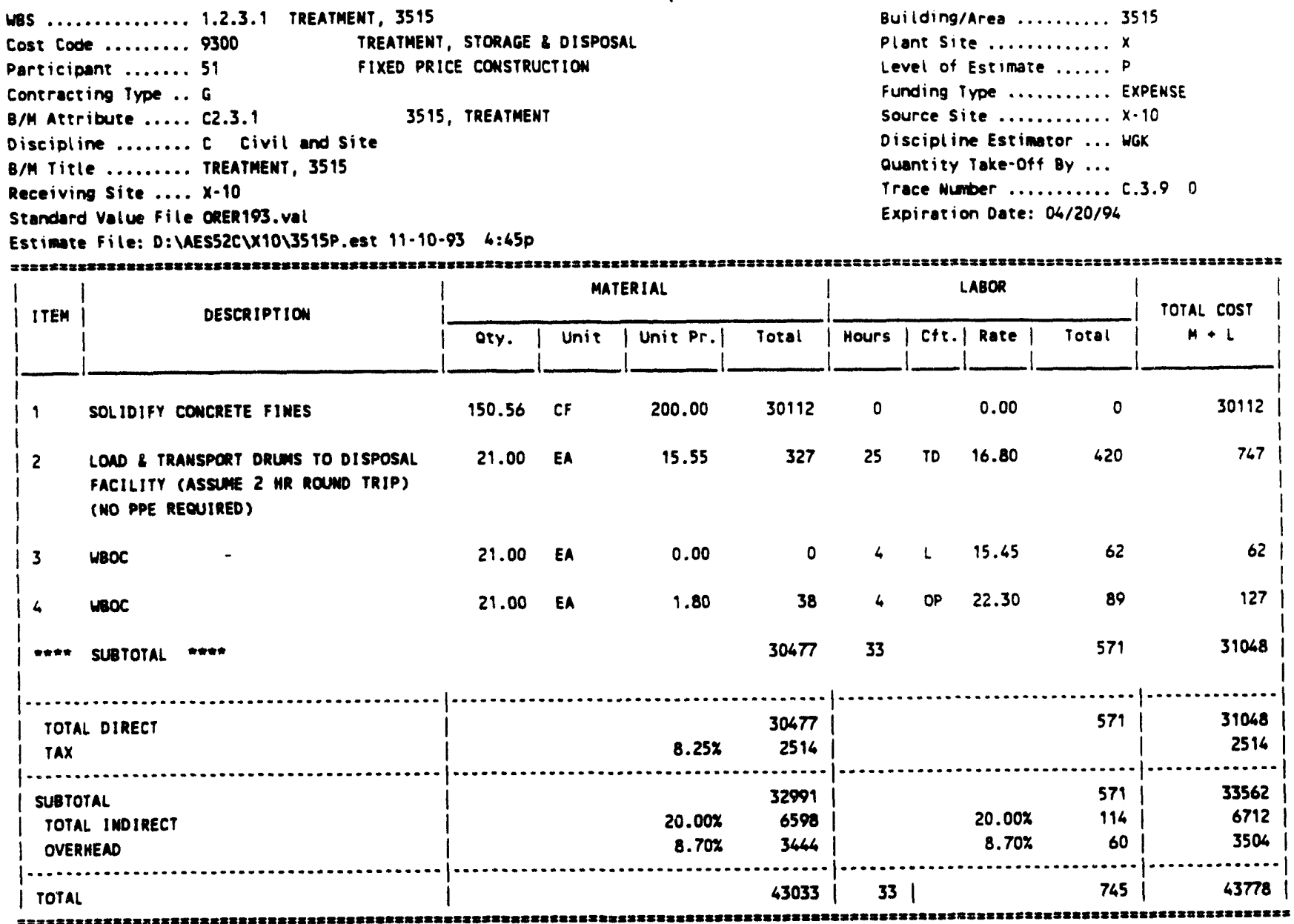


D \& O BLDG 3515, PARTIAL

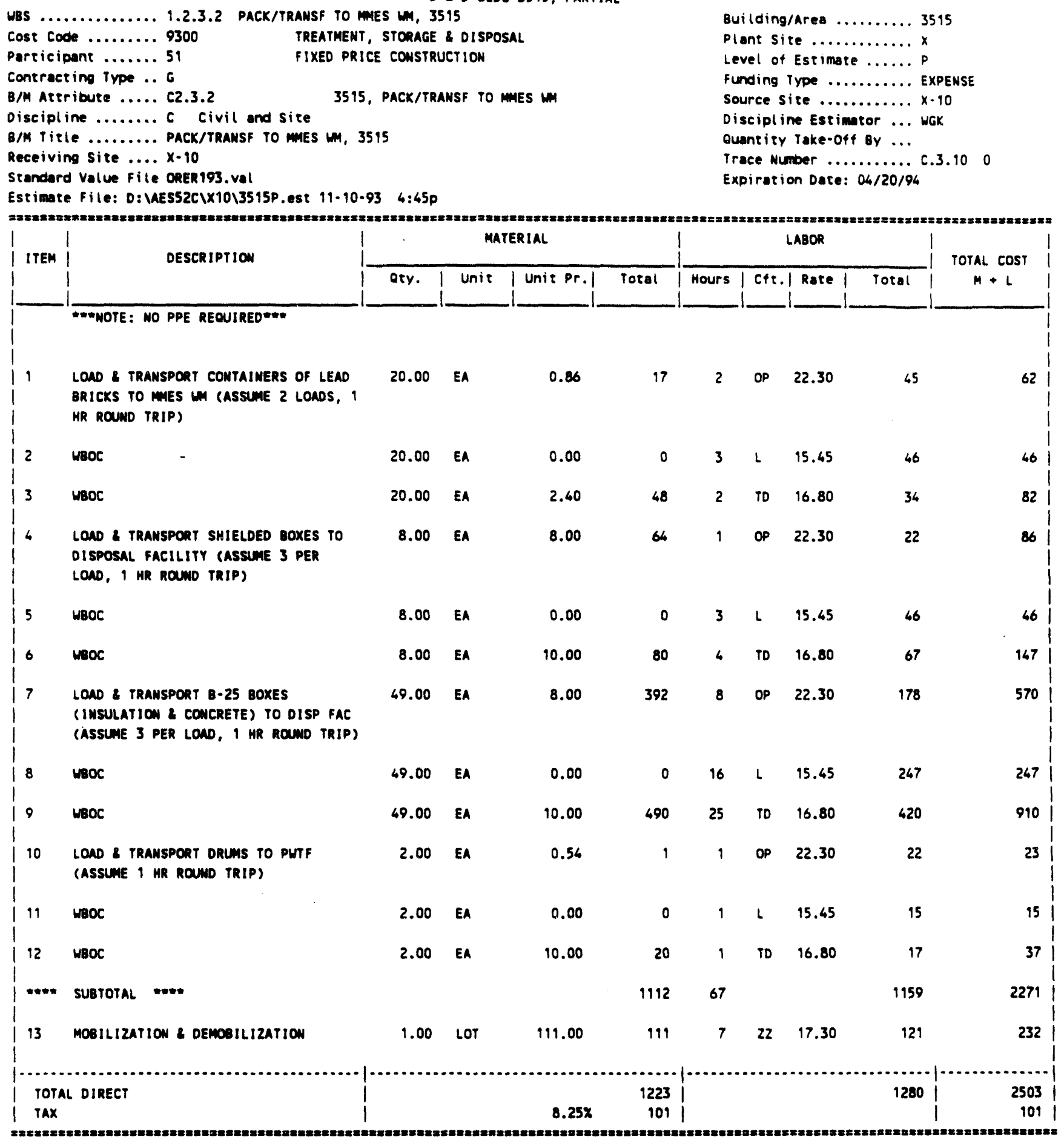


D E BLOG 3515, PARTIAL

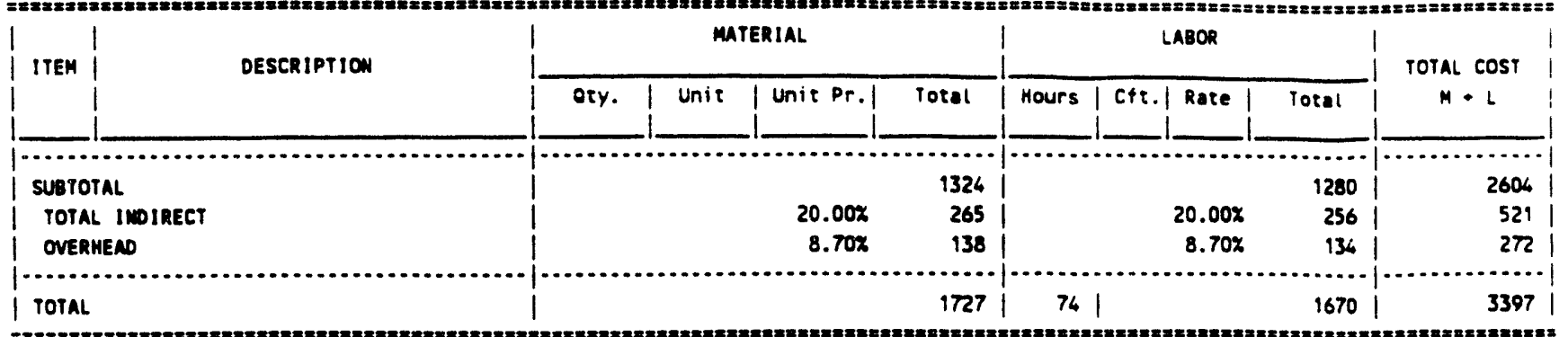


D I D BLOG 3515, PARTIAL

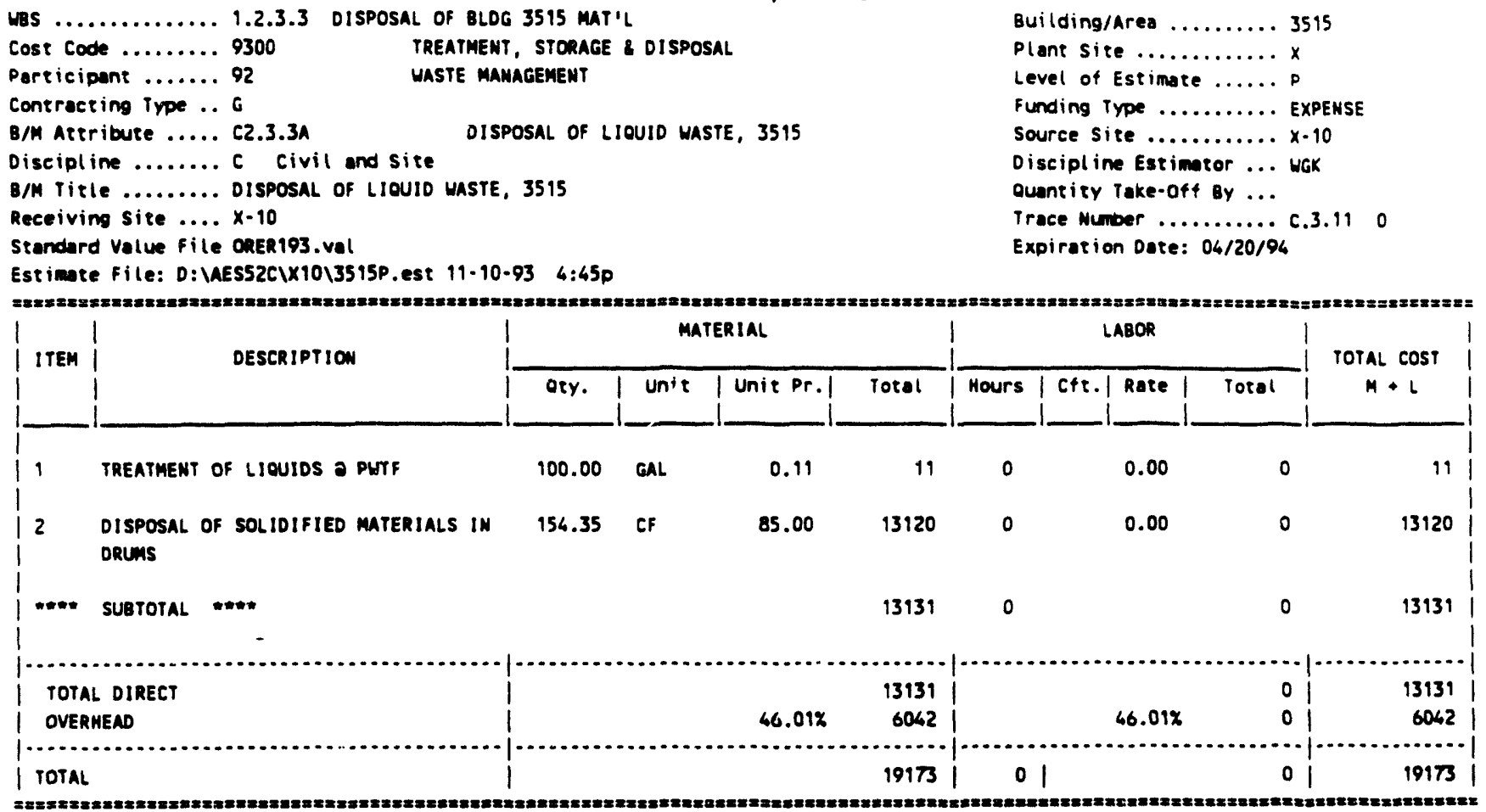


D \& D BLDG 3595, PARTIAL

WBS $\ldots \ldots \ldots \ldots \ldots \ldots 1.2 .3 .3$ DISPOSAL OF BLDG 3515 MAT'L

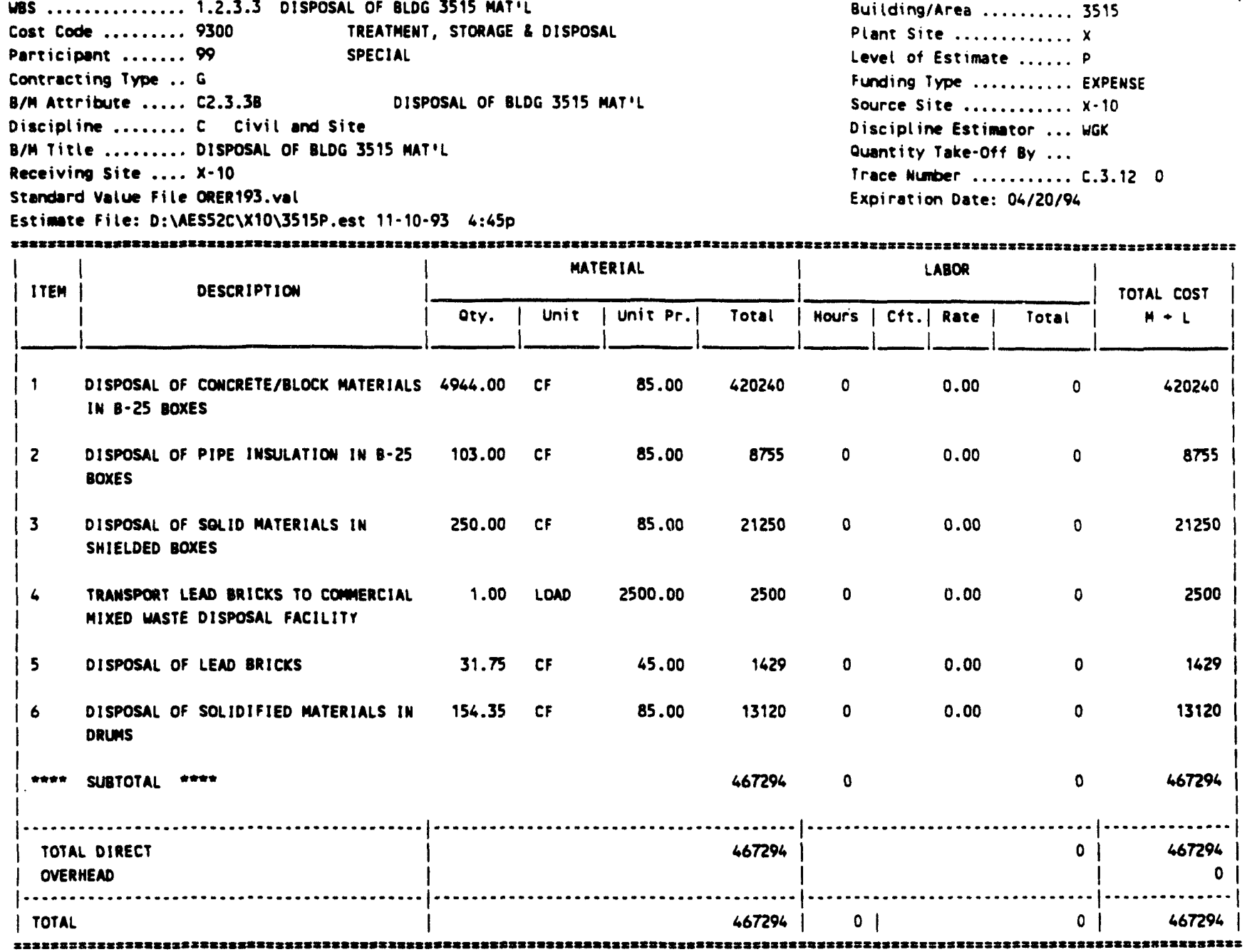


D \& D BLDG 3515, PARTIAL

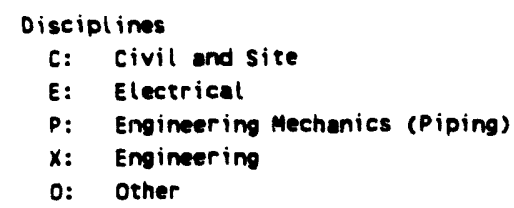

COST SUMMARY

\begin{tabular}{|c|c|c|c|}
\hline 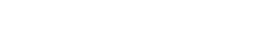 & MATERIAL & LABOR & TOTAL COST I \\
\hline Line $1 \mathrm{ten} \cos t$ & $1082743 i$ & 979268 & 2062011 \\
\hline Total Tax & 48726 & 01 & 48724 \\
\hline$\ldots \ldots \ldots$ & & & 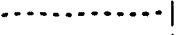 \\
\hline SUBTOTAL & $1131467 i$ & 979268 | & 2910735 \\
\hline Total Indirect & 187877 & $78869 \mid$ & 266746 \\
\hline 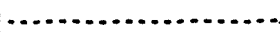 & $\cdots \cdots \cdots$ & $\ldots \ldots \ldots$ & $\ldots \ldots \ldots \ldots$ \\
\hline SUBTOTAL & $1319344 i$ & 1058137 & 2377481 \\
\hline Overhead & 167728 & 147813 & 315541 \\
\hline | & $\cdots-1$ & 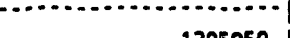 & (1)....... \\
\hline SUBTOTAL & 1487072 & 1205950 & 2693022 \\
\hline Cont ingency & $492247 i$ & 613773 & 906020 \\
\hline $\mid \cdots \ldots \ldots$ & $\cdots \cdots \cdots$ & 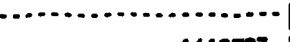 & $\cdots \cdots$ \\
\hline SUBTOTAL & $1979319 i$ & 1619723 & 3599042 \\
\hline Market Adjustment & i & & 0 \\
\hline TOTAL & 1 & & 3599042 \\
\hline
\end{tabular}




\section{DISTRIBUTION}

1. H. L. Boston

2. T. W. Burwinkle

3. K. Constant

4. O. W. Hale

5. J. H. Hooyman

6. G. R. Hudson

7. M. A. Johnson

8. M. R. Jugan

9. L. L. Kaiser

10-11. G. J. Mandry

12-14. D. M. Matteo

15-16. P. T. Owen

17. C. E. Pepper

18. P. A. Schrandt

1.9. W. T. Thompson

20. M. L. Whitehead

21. P. S. Wood

22-24. ORNL ER Document Management Center

25-27. Central ER Document Management Center

28. Laboratory Records Department

29. ORNL Patent Section

30. Central Research Library

31. Office of Assistant Manager for Energy Research and Development, DOE Oak Ridge Operations Office, P.O. Box 2001, Oak Ridge, TN 37831-8600

32. R. C. Sleeman, DOE Oak Ridge Operations Office, P.O. Box 2001, Oak Ridge, TN 37831-8541

33. J. T. Sweeney, DOE Oak Ridge Operations Office, P.O. Box 2001, Oak Ridge, TN 37831-8541

34-35. Office of Scientific and Technical Information, P.O. Box 62, Oak Ridge, TN 37831 

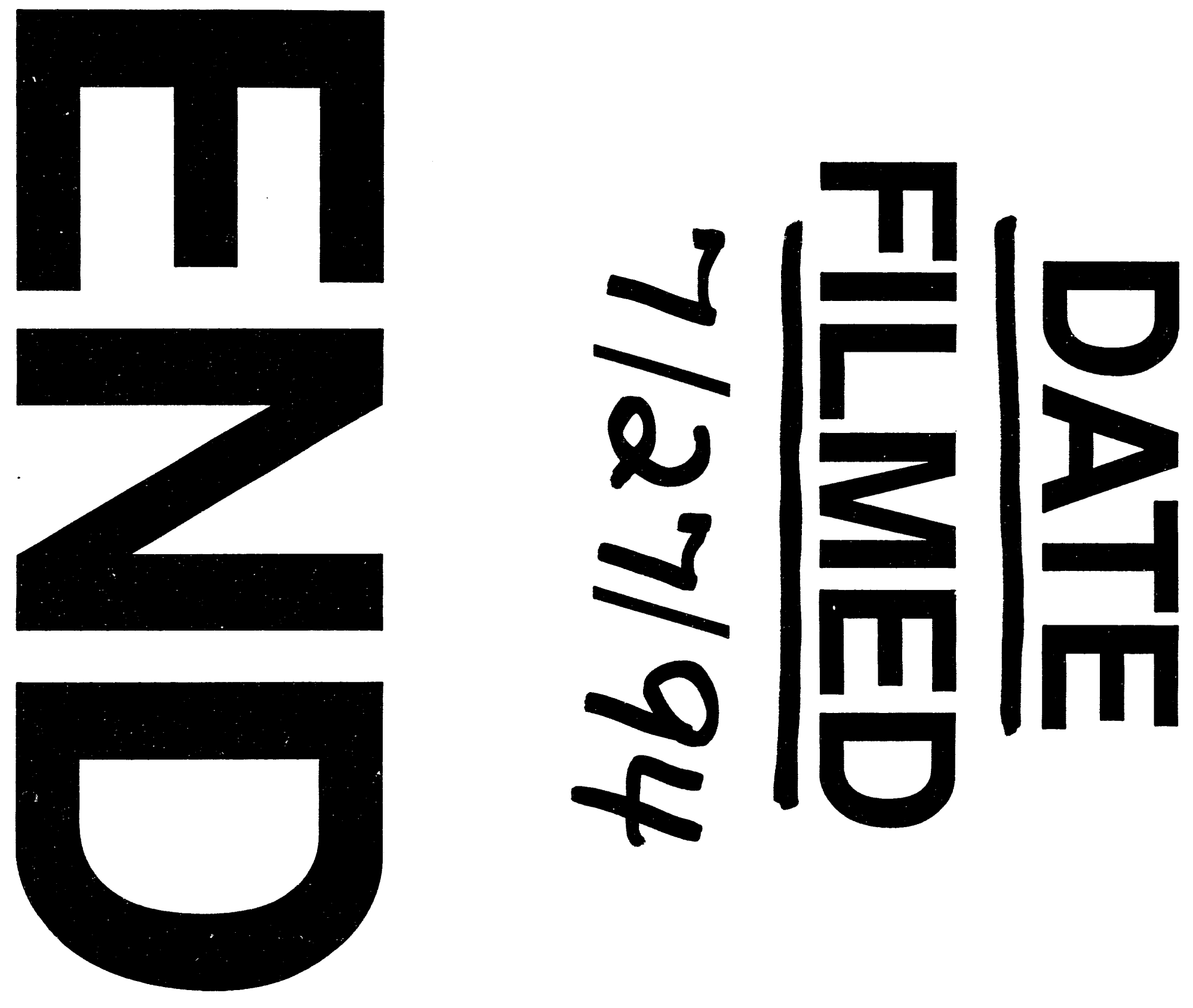
